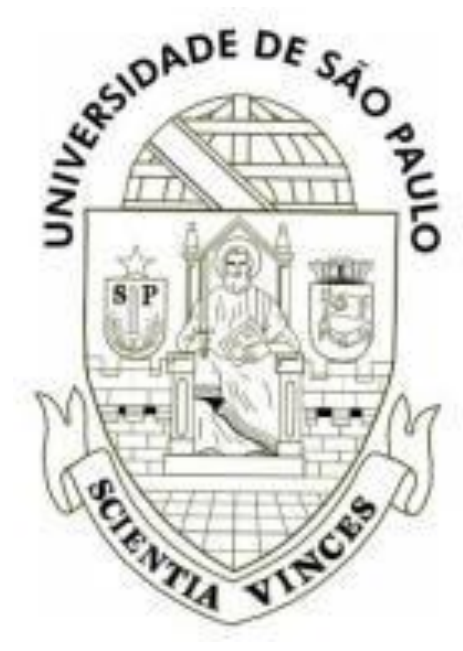

\author{
UNIVERSIDADE DE SÃO PAULO \\ FACULDADE DE FILOSOFIA, LETRAS E CIÊNCIAS HUMANAS \\ DEPARTAMENTO DE HISTÓRIA \\ PROGRAMA DE PÓS-GRADUAÇÃO EM HISTÓRIA SOCIAL
}

FABIANA ORTIZ DO NASCIMENTO

A CANETA DO ESTADO - Políticas Públicas de Esporte no Estado de São Paulo durante o Regime Militar (1964-1972)

Orientador: Prof. Dr. Flávio de Campos

Versão Corrigida

São Paulo

2021 
FABIANA ORTIZ DO NASCIMENTO

\title{
A CANETA DO ESTADO - Políticas Públicas de Esporte no Estado de São Paulo durante o Regime Militar (1964-1972)
}

\author{
Dissertação apresentada ao Departamento de \\ História Social da Faculdade de Filosofia, Letras e \\ Ciências Humanas da Universidade de São Paulo, \\ para a obtenção do título de Mestre em História \\ Social. \\ Orientador: Prof. Dr. Flávio de Campos
}

Versão Corrigida

São Paulo 
Autorizo a reprodução e divulgação total ou parcial deste trabalho, por qualquer meio convencional ou eletrônico, para fins de estudo e pesquisa, desde que citada a fonte.

Catalogação na Publicação

Serviço de Biblioteca e Documentação

Faculdade de Filosofia, Letras e Ciências Humanas da Universidade de São Paulo

N244C

Nascimento, Fabiana Ortiz do

A CANETA DO ESTADO - Políticas Públicas de Esporte no Estado de São Paulo durante o Regime Militar (1964-1972) / Fabiana Ortiz do Nascimento; orientador Flávio de Campos - São Paulo, 2021. $185 \mathrm{f}$.

Dissertação (Mestrado) - Faculdade de Filosofia, Letras e Ciências Humanas da Universidade de São Paulo. Departamento de História. Área de concentração: História Social.

1. Esporte. 2. Ditadura Militar. 3. Gestão Pública de Esporte. 4. Estado de São Paulo. I. Campos, Flávio de, orient. II. Título. 


\section{ENTREGA DO EXEMPLAR CORRIGIDO DA DISSERTACÃO/TESE}

Termo de Ciência e Concordância do (a) Orientador (a)

Nome do (a) aluno (a): FABIANA ORTIZ DO NASCIMENTO

Data da defesa: 14/06/2021

Nome do Prof. (a) orientador (a): FLAVIO DE CAMPOS

Nos termos da legislação vigente, declaro ESTAR CIENTE do conteúdo deste EXEMPLAR CORRIGIDO elaborado em atenção às sugestões dos membros da comissão Julgadora na sessão de defesa do trabalho, manifestando-me plenamente favorável ao seu encaminhamento e publicação no Portal_ Diaital de_Teses da USP.

São Paulo, 19/08/2021

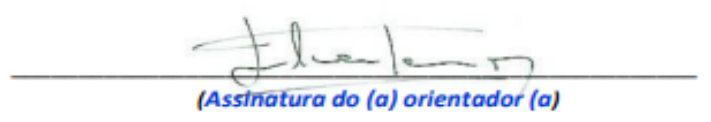


Para Célia e Damásio. 


\section{AGRADECIMENTOS}

Agradeço ao meu orientador e amigo, Professor Doutor Flávio de Campos, por toda paciência, dedicação e pelo carinho. Muito obrigada por tanto! Quero também agradecer aos professores Ismara Izepe de Souza e Antônio Carlos Mazzeo, que fizeram parte da minha banca de qualificação, muito obrigada pela leitura atenta, pelas críticas e pelos apontamentos que me direcionaram para o melhor desenvolvimento deste trabalho, e pelos elogios que me deram confiança para seguir em frente. $E$ obrigada pela disposição de estarem presentes em uma qualificação marcada em uma manhã tão triste para esse país. Agradeço também à professora Vivian Lehnen Coutinho, por ter me guiado por toda a graduação e me auxiliado inúmeras vezes ao fim dela, das mais diversas formas, por ter me indicado esse caminho e me inspirado, acreditando que eu poderia segui-lo. Agradeço ao Professor Doutor Mario Jorge da Motta Bastos, por toda sua disposição em ajudar no início dessa caminhada.

Quero agradecer aos meus pais, Célia e Damásio, por todo amor e apoio sem os quais eu nada teria feito, e ao meu irmão, Rafael Ortiz, por todo ombro cedido e pelos pedidos de ajuda atendidos até aqui. Aos meus amigos, os meus "ticos" cariocas, Thiago Magela e Eduardo Daflon, por todo o apoio, toda a amizade e o ouvido dedicado a queixas que, mesmo longe, eles parearam comigo; Doglas Lubarino, pela revisão e pelo incentivo; Toni e Pri, pelo chope e acolhimento nos fins de tarde dos dias difíceis.

$\mathrm{E}$, in memoriam, eu gostaria de agradecer à Paula Mikame Souza, por toda bronca e conjunção; à Regina Claro, pelo incentivo e pelo brigadeiro quando pensei em não seguir; e ao meu primo, Valdenízio Petrolli, que mesmo sem saber, fez com que eu me interessasse por história desde os meus primeiros anos de vida. 
"Em $1^{\circ}$ de abril de 1964, Corinthians e São Paulo se enfrentariam em partida válida pelo Torneio Rio-São Paulo daquele ano. Na mesma noite, o [...] presidente do Congresso Nacional declarava vaga a presidência da República. [...]. O clássico paulista, então, mudou de data. O país e o esporte mudaram de rumo."

Antônio Strini e Thiago Cara, ESPN, 2014. 


\section{RESUMO}

\section{A CANETA DO ESTADO - Políticas Públicas de Esporte no Estado de São Paulo durante a Ditadura Militar (1964-1972)}

O objetivo desta pesquisa é analisar como se deu a atuação do governo no campo desportivo durante a Ditadura Militar no estado de São Paulo, no período compreendido entre 1964 e 1972. Buscamos percorrer indícios das relações que pautavam essas ações, e o porquê de o esporte ter se tornado um tema tão caro para o governo ditatorial, passando a ser uma pasta considerada essencial. Fazemos um apanhado das ações de governo no campo da educação física escolar, da construção de equipamentos e infraestrutura para que ela pudesse ocorrer, além de elencar quais equipamentos do estado de São Paulo ganharam mais investimentos ao longo do período proposto, para quais concessões foram construídos e/ou reformados. Para tanto, usamos fontes oficiais, extraídas do Diário Oficial de São Paulo, com a descrição das ações executivas e dos discursos e atos legislativos acerca do esporte.

Palavras-Chave: Ditadura Militar; Estado de São Paulo. Esporte, Educação Física, Políticas Públicas. 


\section{ABSTRACT \\ THE PEN OF THE STATE - Sports Public Policy at the State of São Paulo during the Military Dictatorship (between 1964 and 1972)}

This study aims to analyze how the government acted towards the sports field during the Military Dictatorship in the State of São Paulo, in the period between 1964 and 1972. We seek to look for signs of the relationships that guided these actions, and the reason why this sport has become such a dear theme for the dictatorial government, becoming a topic to be considered vital. We take a general look at governmental actions in the field of school physical education, the construction of equipment and infrastructure so the sport could be played, in addition to listing which field in the State of São Paulo received more investments over the proposed period, and for which concessions they were built and / or renovated. For that, we use official sources, extracted from the Official Gazette of São Paulo, with the description of the executive actions, speeches and legislative acts about sport.

Keywords: Military Dictatorship; State of São Paulo. Sport, Physical Education, Public Policy. 


\section{LISTA DE FIGURAS}

Figura 1 - Pelé e o Fusca que ganhou.

Figura 2 - Capa do Diário Oficial de 22 de junho de 1965. Note-se o destaque dado para a infraestrutura que teria a educação física junto à educação formal.

Figura 3 - Capa do Diário Oficial de SP de 29 de abril de 1964. A propaganda em torno do esporte gozava de visibilidade inclusive em documentos oficiais.

Figura 4 - Projeto Reynaldo Dierberger, 1929: estádio.

Figura 5 - Mapa Geral do Parque Ibirapuera - Comissão do IV Centenário, São Paulo, 1954. Item 7 - Ginásio; Item 8 - Velódromo.

Figura 6 - Capa do Diário Oficial de SP em 14 de maio de 1964. A propaganda evidenciava a pressa na realização da obra que seria, mais tarde, concedida ao II Exército. 


\section{LISTA DE SIGLAS}

Alesp - Assembleia Legislativa do Estado de São Paulo

CMPSP - Câmara Municipal de São Paulo

DEFE - Departamento de Educação Física e Esportes do Estado de São Paulo

DO - Diário Oficial do Estado de São Paulo 


\section{SUMÁRIO}

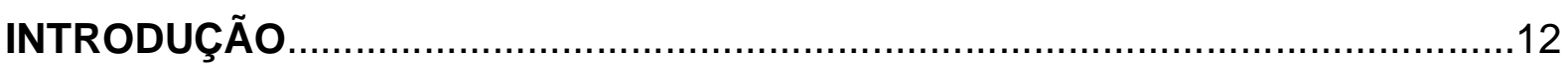

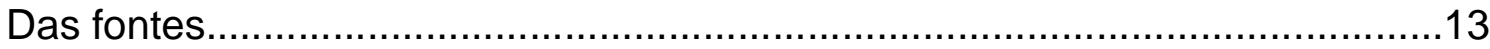

\section{CAPÍTULO}

I.

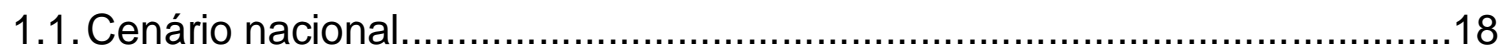

1.2. O Golpe de Estado no estado de São Paulo.........................................19

1.3. Recentes interpretações sobre a Ditadura Militar.......................................21

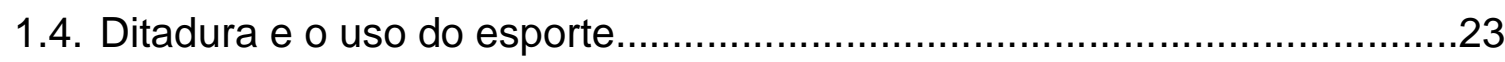

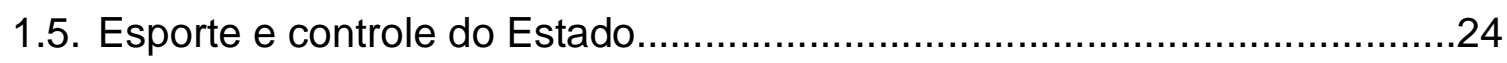

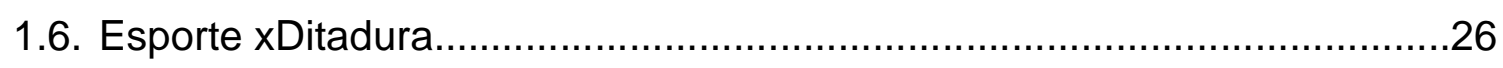

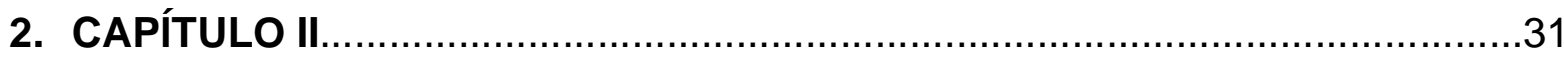

2.1. Educação em tempos de ditadura.........................................................

2.2. Disciplina dos corpos, educação esportiva, moral e cívica..........................33

2.3. A Educação Física no estado de São Paulo............................................39

2.3.1. Governo Adhemar de Barros (1964-1966) - Foco em infraestrutura

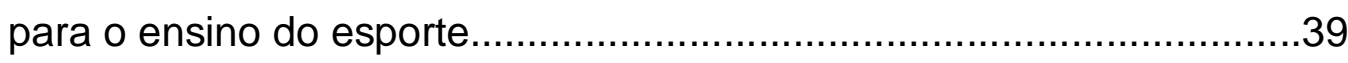

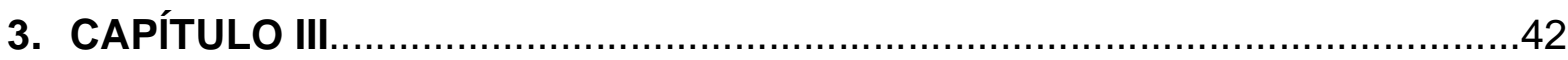

3.1. Políticas Públicas e Política de Esporte...................................................42

3.2. Panorama das ações governamentais no campo esportivo no estado de São

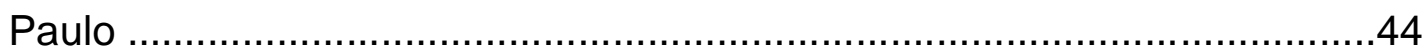

3.3. Ações do Poder Executivo, ou que fizeram os governadores......................45

3.3.1. Governo Adhemar de Barros (1964-1966) - Estruturação....................45

3.3.2. Primeiro governo Laudo Natel (1966-1967) - Transição......................52

3.3.3. Governo Abreu Sodré (1967-1971) - Normatização............................57

3.3.4. Segundo governo Laudo Natel (1971-1972) - Integração......................64

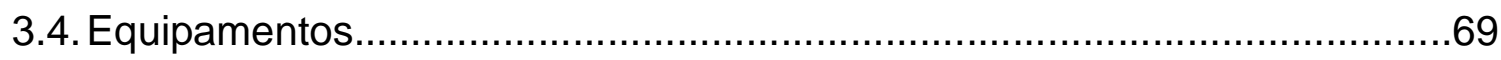

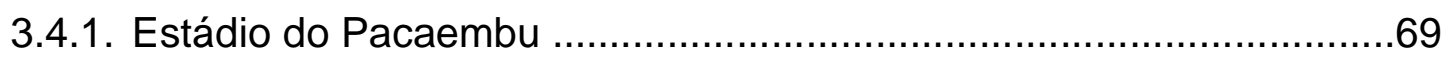

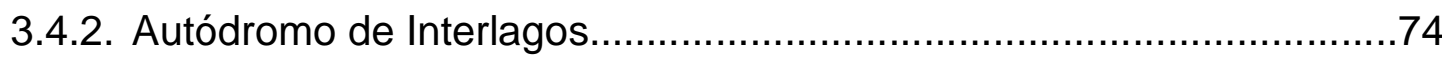

3.5. O (conceito de) Esporte nos governos do Estado.......................................75 


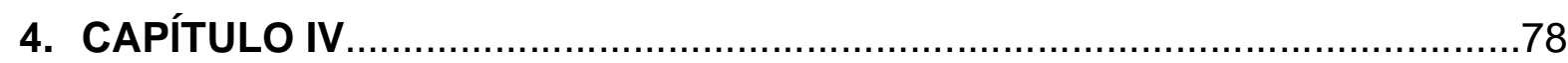

4.1. Da criação do Parque Ibirapuera - Breve histórico.....................................78

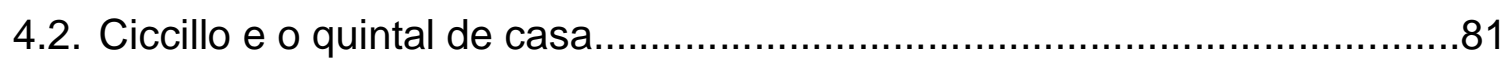

4.3. A luta por espaços, ou a falta de espírito esportivo.....................................82

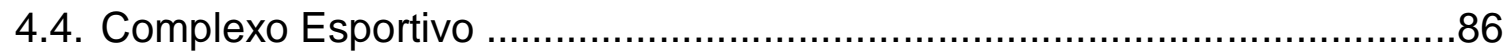

4.5. Entre as ruas Manoel da Nóbrega e Abílio Soares......................................86

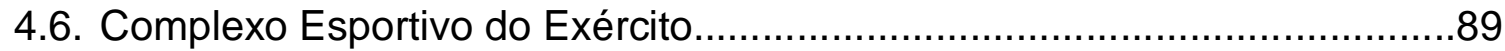

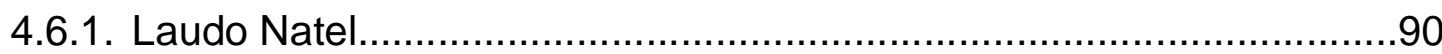

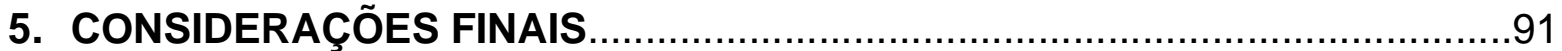

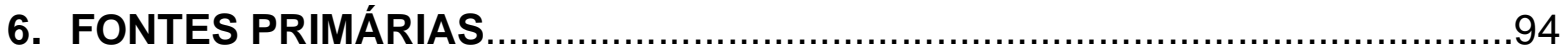

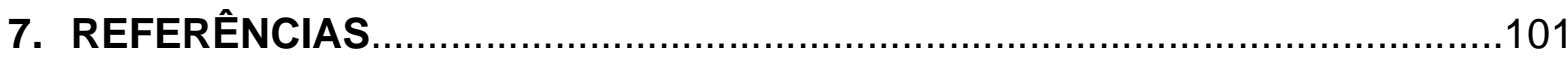

8. ANEXO 


\section{INTRODUÇÃO}

A análise da política de esporte adotada na ditadura militar brasileira precisa considerar os interesses dos diversos setores da sociedade que se beneficiaram com as ações tomadas pelo governo neste campo. Ainda que possamos identificar motivações sem maiores aprofundamentos, o projeto de ação no desporto e o investimento público empenhado serviram a diversos grupos de interesses distintos, sempre ligados às elites nacionais.

Podemos dizer que diversos atores compunham a correlação de forças que determinava as diretrizes da política de esportes nacional, e que esse jogo de poderes se propagava nos estados, sendo o estado de São Paulo nosso objeto de estudo. Empresários esportivos, empreiteiras, imprensa, ligas e federações esportivas forçavam seus interesses sempre interagindo com o núcleo de poder do Exército e com o projeto de identidade nacional empregado por ele através do esporte.

Nessa correlação de forças, damos especial destaque para as trocas estabelecidas entre os "poderes civis"1 ainda em exercício, que ocupavam cargos no Poder Executivo, como os governadores, vereadores e deputados do estado de São Paulo (em momentos de casas legislativas abertas), pelas indicações de postos em cargos estratégicos na gestão pública e pela execução de políticas e construção de equipamentos que serviam como trocas de favores e acenos de condescendência ao poder militar estabelecido.

A definição do tema da presente pesquisa baseou-se na lacuna de informações sobre as políticas públicas de esporte no período estudado e na vontade de entender como se estabelecia o jogo de interesses dentro dos poderes do estado. Após essa definição, passamos a "procurar" quais fontes nos forneceriam os dados para compreendermos a atuação do Estado no esporte.

Pesquisamos os nomes dos governadores do período proposto, dos prefeitos da cidade de São Paulo e de parlamentares ligados ao esporte, como Adhemar de

\footnotetext{
${ }^{1}$ Colocamos "poderes civis" entre aspas nesse trecho pois estava totalmente submetido ao governo militar, sendo este que detinha real poder sobre as indicações dos cargos estratégicos e das políticas públicas empregadas pelos governos.
} 
Barros, buscando suas filiações, cargos ocupados e ligações com entidades desportivas.

Também buscamos conhecer a legislação nacional referente ao esporte e à educação física produzida durante o período militar. Nessa busca, analisamos documentos como o Diagnóstico da Educação Física/Desportos no Brasil, de caráter aparentemente tecnicista, criado para disciplinar os gastos da Loteria Esportiva Federal e que serviu de base para o planejamento das ações do governo nacional no campo dos esportes. A leitura desse documento nos foi bastante esclarecedora de qual era o projeto pretendido, o que trabalharemos em capítulo específico sobre a educação física no período.

\section{Das fontes}

Para entender por que meios esse projeto seria aplicado, passamos então a buscar a legislação de caráter normativo do período, ou seja, a que parte da iniciativa do Poder Executivo, como os decretos e as portarias emitidos pelos governadores do estado de São Paulo dentro do recorte proposto.

Esse primeiro levantamento foi feito buscando o acervo do Arquivo Histórico do Estado de São Paulo. Contudo, essa busca se mostrou incapaz de apontar os parâmetros completos das ações do governo no esporte já em seu início, então passamos para o levantamento mais completo, a partir do Diário Oficial do Estado de São Paulo e Municípios. O uso do Diário Oficial como fonte foi possível devido à digitalização completa dos exemplares publicados, o que facilitou nossa pesquisa, apesar de alguns arquivos estarem ilegíveis e demandarem a sua busca física no Arquivo do Estado.

No sítio eletrônico do Diário Oficial, optamos por fazer o levantamento usando a palavra-chave "esport" no campo de busca, assim receberíamos arquivos nomeados tanto como esporte como desporto, ampliando o alcance da pesquisa. Fizemos essa busca dentro do período compreendido entre 31 de março de 1964 e 31 de dezembro de 1972, selecionando os cadernos Executivos, Suplementos, Diário Oficial da Cidade de São Paulo, Legislativo e Edital e leilão, e obtivemos, assim, pouco mais de 4 mil arquivos, os quais organizamos em uma tabela de maneira cronológica. 
A leitura desse material nos permitiu ter um quadro completo das ações governamentais no campo dos esportes no estado de São Paulo, tanto do Poder Executivo quanto do Legislativo. Os subtemas foram os mais diversos possíveis: esporte escolar, amador, grandes eventos, construções e homenagens diversas para atletas e dirigentes das associações esportivas. A partir da leitura, fizemos a seleção do que julgamos mais relevante, descartando arquivos ligados a burocracias de caráter mais corriqueiro, como licenças médicas de servidores, aposentadorias e outros dessa mesma ordem. Chegamos assim a uma seleção de 480 publicações de cunho mais significativo.

Em seguida, buscamos tipificar esse material dentro das seguintes categorias: Data da publicação; Órgão (indicando qual o órgão do governo foi responsável pela ação); Tipo (definindo qual o tipo da ação, se se tratava de ato do Poder Executivo, Legislativo ou pronunciamento legislativo); Subcategoria (definindo se a ação era normativa, como um decreto, ou se era simplesmente uma nota de pesar, por exemplo); Identificação (indicando o número da ação, quando possível); Descrição (explicando detalhadamente do que cada ação se tratava).

Esse levantamento nos levou a compreender que a divisão cronológica dos governos do estado de São Paulo também foi marcada por divisões muito claras do que podemos chamar de missões de governo, o que pautamos ao longo do terceiro capítulo desta pesquisa.

O primeiro governo do estado após o golpe militar foi o do governador Adhemar de Barros (1964-1966), e esteve mais empenhado em promover a infraestrutura necessária para a prática esportiva no estado e a intensificação da educação física nas escolas, conforme as diretrizes apontadas no Diagnóstico da Educação Física/Desportos no Brasil.

O governo de Laudo Natel (1966-1967), foi de transição entre a construção de equipamentos e a implementação de políticas de esporte, e quando teve início a apresentação de projetos no campo legislativo. Essa integração com a Assembleia Legislativa do Estado de São Paulo foi continuada durante o governo de Abreu Sodré (1967-1971), e foi um período de busca por normatizações para o esporte e a educação física. Quando Laudo Natel reassumiu para um segundo mandato (1971- 
1972), seu governo preocupou-se, sobretudo, com a integração com o interior do estado e com a expansão das políticas aplicadas na capital.

Nossa pesquisa também nos mostrou a importância dos grandes equipamentos para o governo ditatorial. O estádio do Pacaembu foi alvo de inúmeras intervenções estaduais, apesar de ser um equipamento municipal da cidade de São Paulo, e palco de disputas políticas, de caráter político e simbólico, bastante relevantes em nossa opinião, conforme trataremos adiante. Além das disputas entre estado e município, entidades de esporte, como a Federação Paulista de Futebol, também foram agentes de conflitos envolvendo o estádio.

Nos remetendo às trocas entre os poderes militar e civil, nos debruçamos sobre a construção do complexo do Ibirapuera, do qual trataremos exclusivamente no quarto capítulo, devido à magnitude das ações e sua articulação com o II Exército, visto que nos pareceu, no decorrer da pesquisa, que foi claramente um caso de aceno do governador Adhemar de Barros aos militares em troca de apoio para sua continuidade no cargo e viabilidade do seu nome para pretensões futuras.

Outro equipamento que teve especial atenção do governo no período proposto foi o Autódromo de Interlagos. Este foi reformado por pressão da imprensa, principalmente pelo jornal Folha de São Paulo, exemplificando o quanto grupos empresariais e de imprensa conseguiam influir nas obras públicas de acordo com seus interesses, sempre representados por um parlamentar civil.

Podemos dizer que a partir da década de 1990 tornou-se possível o desenvolvimento de diversos estudos acerca do período militar, com base na abertura dos Arquivos da Repressão dos chamados Departamentos Estaduais de Ordem Política, que, segundo Carlos Fico, contribuem para o Brasil ter "um dos maiores acervos públicos de documentos outrora sigilosos produzidos por uma ditadura militar" (FICO, 2012, p. 56). Diversos trabalhos foram feitos e, falando do estado de São Paulo, que nos interessa particularmente, podemos citar aqui os esforços do PROIN², que compilou extenso material que serviu de apoio aos pesquisadores que se

\footnotetext{
2 Projeto Integrado do Arquivo Público do Estado de São Paulo e Universidade de São Paulo. Foram feitos dois trabalhos: o primeiro é a Série "Inventário DEOPS", que foi criada em 1996 como um instrumento de apoio aos pesquisadores interessados em consultar o acervo da Polícia Política do Estado de São Paulo, sob a guarda do Arquivo do Estado, e o segundo a coleção "Histórias da Repressão e da Resistência", que deriva do primeiro trabalho, e permite avaliar as ações de instituições brasileiras que tem como função a seleção e o controle do cidadão.
} 
interessavam pelos arquivos ligados aos Deops/SP. Reconhecemos que, apesar das duas décadas de abertura, o volume de material disponibilizado está longe de ter-se esgotado. Dele já fizeram uso diversas pesquisas de suma importância para reconhecermos a história do período, e como se fazia uso político do aparato estatal.

Contudo, percebemos que, justamente pela abertura dos arquivos outrora secretos, outras fontes de pesquisa que poderiam elucidar questões sobre a atuação dos militares durante a sua ditadura no Brasil não têm sido tão consideradas, como é o caso dos diários oficiais, por serem documentos de ordem pública inclusive durante o regime. Porém, acreditamos ser possível extrair deles diversas informações sobre o uso político do Estado, fazendo o cruzamento de informações publicadas e buscando a contextualização dos atos administrativos ali escritos, permitindo, assim, uma leitura das "entrelinhas" do poder vigente.

No que tange a literatura que buscou entender como se deu a temática esportiva dentro das políticas de estado, nosso trabalho se baseia nos estudos de dois autores, principalmente. Citamos primeiramente o trabalho pioneiro de Eduardo Dias Manhães, em que buscou analisar à luz da sociologia processos de democratização de acesso ao esporte e a atuação das políticas públicas nesse processo, percebendo que a falta de acesso ao esporte era oriunda de seu uso por regimes autoritários. Dado que seu trabalho começa com o período Vargas, ele buscou compreender "a forma como [o Estado] articulou historicamente as formas de manifestações desportivas, o 'participativo' e o 'seletivo', tendo como referencial a prioridade de um ou de outro." (MANHÃES, 2002, p. 17), deixando ainda aberta a questão de como se deu esse uso.

Em seguida, citamos o trabalho de Meily Assbú Linhales (1996), que buscou compreender o porquê de o estado se ocupar do esporte. $O$ trabalho é pautado na ciência política, e nos foi de enorme valia para obtermos as ferramentas necessárias ao entendimento de certas questões que apareceram ao longo desta investigação.

Nossa pesquisa previa ainda proceder com a prosopografia dos agentes públicos que autorizavam ou motivavam as ações do governo no esporte. No entanto, precisaríamos retornar ao Arquivo do Estado para proceder com a pesquisa em processos da época, o que nos foi impedido pelo período de Pandemia. Porém, esta 
lacuna não atrapalhou o desenvolvimento da pesquisa em seu cerne, e nos deixou a possibilidade de continuidade do trabalho. 


\section{CAPÍTULO I}

\subsection{Cenário nacional}

O Golpe de Estado que tirou João Goulart da Presidência da República, em 1ํㅡ de abril de 1964, ocorreu sem grande resistência e deu início a um período de controle e repressão, quebrando a continuidade democrática tão recente no Brasil.

Os trabalhadores hão de parar porto por porto, navio por navio, fábrica por fábrica, e as greves vão também parar o campo, [...]. Querem a guerra civil, pois teremos revolução social. Querem sangue, pois nós aceitaremos o sangue. [...] Uma guerra civil não se faz com marechais, almirantes e generais. Faz-se com a tropa, e essa tropa é o povo e é o povo que compõe todos os quartéis. São os sargentos, os cabos, os marinheiros. Esse passo, de natureza revolucionária, Jango não deu. (GASPARI, 2002, p. 86).

Durante o final de 1963, Jango aproximou-se de grupos extraparlamentares alinhados mais à esquerda, devido ao seu isolamento político, buscando apoio para suas reformas de base, que até então eram sua principal bandeira (MATTOS, 2019). Os setores mais conservadores da sociedade não permitiriam uma guinada do presidente à esquerda, e a justificativa de combate ao comunismo foi basilar para a deflagração do golpe.

Os jornais da época se empenharam em criar uma aura de ilegalidade em torno do governo de Jango, e o acusavam de pautar as reformas com o único intuito de fazer passar, através da reforma da Constituição, o projeto que garantiria sua reeleição e a legalização do Partido Comunista (Ibidem.). Havia também um esforço de se construir no imaginário das pessoas o que seria considerado a política feita de forma baixa, pautada em interesses pessoais e corruptíveis, representada pela pretensão de setores da esquerda de obter meios mais efetivos de representação; e por outro lado, a política feita com "bom senso" e "moralidade", que respeitava as instâncias democráticas e os valores da sociedade, através do Congresso (Ibidem.). 
Sendo assim, era inadmissível a proximidade de Jango com o primeiro setor. Foi evocando esses princípios de retorno à legalidade e à moralidade que Jango foi deposto, e iniciou-se no país um regime

marcado pelo autoritarismo militar, redução ou supressão de direitos constitucionais, repressão policial. Censura à imprensa, controle casuístico do processo político, esvaziamento do Poder Legislativo, limitação do Judiciário e domínio arbitrário do Poder Executivo. (COUTO, 1999, p. 41)

Os principais motivos alegados pelos militares para a tomada de poder foram a retomada da legalidade, da moralidade e o combate ao comunismo. Nesse contexto, legalidade e moralidade estavam pautadas em valores cristãos e conservadores, representando interesses das elites, que evocavam a "Democracia" como conceito agregador desses valores (MATTOS, 2019, p. 155).

Após o Golpe, a vacância da cadeira presidencial foi primeiramente preenchida por Ranieri Mazzilli, presidente da Câmara dos Deputados, que permaneceu no cargo por 13 dias, até a eleição e posse de Humberto de Alencar Castelo Branco. Nota-se a tentativa de manter ares de legalidade para todas as ações tomadas pelos militares, tendência esta que se manteve até o fim do regime. Castelo Branco assumiu o cargo de presidente, em detrimento da ala mais conservadora do exército, com o compromisso de ficar no cargo até o fim daquela legislatura, que seria um período de 18 meses. Contudo, seu mandato foi prorrogado até 1967, apesar de afirmar que "a prorrogação de seu mandato seria a essência da ilegalidade" (SKIDMORE, 1988, p. 90 ), dando início a um período de autoritarismo que perdurou por 21 anos.

\subsection{O Golpe de Estado no estado de São Paulo}

O papel exercido pelo estado de São Paulo na queda de João Goulart foi decisivo. Foi em São Paulo que ocorreu a grande manifestação "popular" contra as reformas defendidas pelo governo. Após meses de instabilidade, Jango se dispôs a participar de uma série de comícios que pretendiam fomentar a pressão popular para a aprovação de suas reformas, organizados junto a setores da esquerda e 
organizações de trabalhadores. Entretanto, ocorreu apenas um, em 13 de março, no Rio de Janeiro, e ficou conhecido como o Comício da Central do Brasil.

Segundo Daniel Aarão (2000, p. 30), São Paulo deu a resposta ao comício em 19 de março, na manifestação que ficou conhecida como "Marcha da Família com Deus Pela Liberdade". Esse movimento, encabeçado pelas elites de São Paulo, foi um contragolpe dos setores de direita após o movimento de esquerda ocorrido no Rio de Janeiro, e contou com 500 mil pessoas, superando as 350 mil do Comício da Central.

Além das manifestações, o governador de São Paulo, Adhemar de Barros, teve um importante papel na queda de Jango, sendo um dos principais articuladores do Golpe. Aqui precisamos frisar que a atuação de forças políticas de São Paulo e as ações de Adhemar de Barros como articulador do Golpe se confundem durante a articulação deste. As tensões entre Adhemar e Jango se acirraram desde outubro de 1963 quando, após um afastamento, o senador José Emídio de Moraes foi enviado pelo governo federal para negociar uma reaproximação e não obteve êxito - Adhemar exigia o afastamento de Jango dos grupos de esquerda, além de cargos no executivo para seu partido, o PSP. Essa negociata fracassada resultou na decisão de afastamento total do governo federal durante a convenção do PSP, no mesmo mês. O partido decidiu que qualquer um dos seus quadros que se aproximasse do governo federal seria expulso (COUTO, 2007).

As tensões entre os governos estavam tão acaloradas, que se chegou a cogitar uma intervenção do governo federal no estado de São Paulo, o que a Casa Civil nota como tentativa de parar o governador. Segundo Couto (2007), Adhemar afastou-se de Jango porque sabia que o presidente não terminaria o mandato, "Adhemar fazia um movimento de resistência em São Paulo, sabia da articulação de alguns setores militares, tinha trânsito livre junto às Forças Armadas. "Ele estava assessorado por alguns militares".

Sabemos que uma importante participação paulista foi a adesão do II Exército, comandado pelo general Amauri Kruel - compadre de Jango - ao movimento golpista, sem o qual seria quase impossível a tomada do governo. São Paulo tinha como secretário de Segurança o general Alevino Barbosa, que colocou o estado como ponto de apoio ao golpe, e sede de resistência caso a incursão militar falhasse (Id., 2007, p. 
220). Proximidades como essa podem ter levado Adhemar a crer que ascenderia ao planalto.

Muito desse desentendimento entre Adhemar e Jango se pautava no oportunismo do governador. Vendo a figura do presidente enfraquecida, Adhemar viu aí uma oportunidade de projetar-se como liderança nacional, visando a eleição para o governo federal em 1965.

Acreditamos que sua participação tão ativa no Golpe se deu pela pretensão de ser nomeado presidente, dada a sua proximidade com as Forças Armadas. Adhemar chegou a declarar em um programa de televisão que poderia se tornar presidente ainda em 1964. Ao contrário disso, acabou deposto com uma "canetada", em 1966, pelo poder que ajudou a instaurar, após tecer críticas públicas ao presidente Castelo Branco.

Ele e outros setores civis que apoiaram o Golpe tiveram seus cargos cassados e seus direitos políticos suspensos por 10 anos, o que nos leva a refletir sobre a natureza do Golpe. Ainda que possa ter sido civil e militar (e aqui não encerramos a questão), a ditadura foi dos militares.

\subsection{Recentes interpretações sobre a Ditadura Militar}

Nas últimas décadas um debate revisionista vem contestando a denominação do regime instaurado no Brasil no período de 1964 a 1985, em detrimento da denominação ditadura militar, achando conveniente o uso do termo "ditadura civilmilitar". Tal movimento se baseia na tentativa de desconstruir uma memória "confortável" da sociedade quanto ao seu apoio ao regime. No entanto, tal revisão pode funcionar também como agente legitimador do discurso dos vencedores - os militares -, que justificam sua ação por meio de um suposto apoio popular.

Citamos o historiador carioca Daniel Aarão Reis, professor Titular de História Contemporânea da UFF, que tem defendido o cunho desta nova denominação. Reis, em artigo publicado no jornal O Globo (2012), defende que a população era contrária às reformas de base de Jango e temia a instauração de um regime comunista no país, e por isso apoiou a tomada do poder pelos militares. Para justificar tal afirmação, argumenta que as massas marcharam nas chamadas Marchas com Deus, pela Pátria 
e Família, organizadas pela Igreja, que ocorreram em diversas capitais brasileiras. Também levanta a questão sobre a formação da burocracia do estado que contava com a ocupação de indivíduos não militares em cargos-chave do governo.

Contudo, em artigo publicado em 2012, Demian Bezerra de Melo refuta esses argumentos constatando que não seria possível, em seguida ao golpe, que a(s) esquerda(s) articulasse $(m)$ manifestações contrárias, o que legitimou as primeiras prógolpe. Em pesquisa realizada pelo Instituto Brasileiro de Opinião Pública - IBOPE em março de 1964 (MELO, 2015), a maioria dos entrevistados não só se dizia favorável às reformas propostas por Goulart, como também manifestavam interesse em eleger Goulart novamente para o cargo de Presidente da República, fato considerável, dado que para tal seria necessária uma mudança constitucional já que a reeleição não era permitida.

No que se refere à questão da ocupação de cargos públicos por civis, Melo cita o trabalho de René Dreifuss, que diz:

Um exame mais cuidadoso desses civis indica que a maioria esmagadora dos principais técnicos em cargos burocráticos deveria (em decorrência de suas fortes ligações industriais e bancárias) ser chamada mais precisamente de empresários, ou, na melhor das hipóteses, de tecno-empresários. (DREIFUSS, 2012).

Segundo Melo (2012), Reis não leva em conta a ligação desses indivíduos ditos "civis" com os militares ou mesmo com a sociedade política dominante que, ainda segundo Dreifuss, faziam parte de uma elite organicamente ligada a interesses do capital multinacional. Em sua tese ele analisa as trocas de dirigentes entre importantes organizações da sociedade civil e o governo, como o IPES (Instituto de Pesquisas e Estudos Sociais), organização que contava tanto com empresários como oficiais de reserva, a exemplo de Golbery do Couto e Silva.

Por fim, pensamos ser importante que os que se propõem a estudar a atuação das Forças Armadas no período ditatorial não compartilhem das visões simplistas da própria corporação que divide a sociedade entre militares e não militares, sendo que a tecnocracia civil era intimamente ligada aos militares e respondia a estes, tirando do cerne da discussão as questões de classes. Apesar da participação civil, o período de governo ditatorial seguiu diretrizes impostas pelo Exército, e manteve nos mais altos 
cargos executivos o seu corpo de generais, que na prática eram quem definiam as políticas.

Sendo assim, no presente artigo nos referiremos ao regime militar apenas como Ditadura Militar.

\subsection{Ditadura e o uso do esporte}

O esporte, enquanto fenômeno social, não passa à margem dos contextos sociais, políticos e econômicos que compõem as sociedades que o acolhem. Tendo ele capacidade de penetrar diferentes estruturas sociais, o esporte comporta interesses que envolvem o Estado, o mercado e as organizações sociais ou sociedade civil, estando por vezes no centro, como motivo ou como condutor, de determinados conflitos.

Sendo assim, os fatores socioeconômicos e políticos podem significar condicionantes decisivos para o desenvolvimento do esporte, sem, contudo, este ficar preso a esses elementos macroestruturais.

A utilização governamental dos esportes como meio de conquistar apoio popular para determinados regimes foi uma prática corriqueira durante todo o século XX. Podemos citar como exemplo desse uso político dos esportes o caso argentino em 1978, quando o governo ditatorial daquele país procurou popularizar o regime através dos bons resultados na organização do evento e da sua seleção. Também vale lembrar o caso alemão dos jogos olímpicos de 1936, realizados sob regime nazista.

O regime militar brasileiro não passou aquém dessa tendência e fez do esporte um de seus pilares apoio popular e político. Durante o governo do General Emílio Garrastazu Médici, no final dos anos 1960, início dos 1970, o governo passou a investir na propagação do esporte, sobretudo na escola pública, sendo que firmou como medida a formação de um grupo de estudos, logo no início de sua gestão, que concebesse um estudo detalhado sobre a situação da Educação Física e do Desporto no país.

Nasceu assim o Diagnóstico da Educação física/Desportos no Brasil, publicado em 1971, teve como supervisor responsável o Tenente Coronel Arthur Orlando da 
Costa Ferreira, e serviu para disciplinar os recursos oriundos da arrecadação com a recém-lançada Loteria Esportiva, conforme Decreto de Lei nํ 594, de 27 de maio de 1969. Esse documento serviu de base para o planejamento das ações do governo no campo esportivo nacional. As motivações do documento, que trazia um caráter tecnicista, diziam visar à melhoria da qualidade de vida dos brasileiros, considerando questões de melhoria da saúde e a importância das interações sociais e psicológicas oriundas do esporte.

A decisão de realizar esse estudo foi uma consequência natural das preocupações do Governo Revolucionário com a política nacional de recursos humanos, dirigida no sentido de aperfeiçoar o homem brasileiro em todos os seus aspectos e melhorar sua qualidade de vida. (RIO DE JANEIRO, 1971, p. 7)

O que podemos ver é que as políticas de esporte estavam entre as ações prioritárias do governo durante o Regime Militar, dada a rapidez com que ações conclusivas foram tomadas durante as trocas de gestão entre os militares. Mas por que os militares se preocupavam tanto com o esporte? Passaremos a essa questão.

\subsection{Esporte e controle do Estado}

Em nossa sociedade capitalista, que convive constantemente com a luta de classes, o Estado promove a oferta de políticas sociais a fim de garantir os direitos a partir de uma série de elementos relacionados na correlação de forças entre essas classes. Sendo assim, a execução de políticas sociais funciona como um mecanismo regulador desses conflitos. Confere aqui afirmarmos que entendemos o esporte como direito social. Nesse sentido o Estado atende, a partir da mesma ação, a interesses antagônicos das classes que compõem a sociedade: se por um lado ele atende às demandas de hegemonia da classe social dominante, por outro a oferta de políticas sociais também responde às pressões dos movimentos sociais ligados à classe trabalhadora. Dentro desta perspectiva baseamos nossa concepção de Estado na definição do marxista italiano Antonio Gramsci (2000) que diz que "na noção geral de Estado entram elementos que devem ser remetidos à noção de sociedade civil (neste 
sentido, seria possível dizer que Estado = sociedade política + sociedade civil, isto é, hegemonia encouraçada de coerção)".

Dentro do campo das motivações por que o Estado se ocupa do esporte e faz dele centro de determinados aparelhos, quando poderia trabalhar com diversas outras temáticas, acreditamos que um dos motivos seja a sua capacidade de ação solidária. Devido ao seu caráter coletivo, as pessoas se organizam, em diferentes graus, em torno no esporte, podendo organizar times, federações e clubes esportivos de bairro. A título de ilustração, citamos a pesquisa de Wanderley Guilherme dos Santos (1993, p.83), que evidencia que no estado de São Paulo, entre as décadas de 1920 e 1980, as organizações esportivas foram as que mais se formalizaram. Vale ressaltar que nem todas as organizações esportivas se institucionalizam, o que faz esse número potencialmente maior e demonstra como a sociedade pode se organizar em torno do esporte. Ressaltamos que apesar de tais organizações não se caracterizarem como movimentos sociais reivindicativos, por terem meramente a prática esportiva como norte, essas organizações não estão desconectadas de seus contextos sociais (LINHALES, 1996). Deste modo, o controle do esporte pelo Estado se constitui em uma importante ferramenta de controle das massas.

Gramsci demonstra desta forma que a atuação estatal serve ao projeto da classe política dominante, e que o Estado funciona ora como interventor que concede o suprimento de determinadas demandas da classe dominada a fim de mediar e diminuir conflitos pontuais, ora como agente repressivo contra os que negam a aparelhagem estatal.

[...] é certamente concebido como organismo próprio de um grupo, destinado a criar as condições favoráveis à expansão máxima de grupo, mas este desenvolvimento e esta expansão são concebidos e apresentados como a força motriz de uma expansão universal, de um desenvolvimento de todas as energias 'nacionais', isto é, o grupo dominante é coordenado concretamente com os interesses gerais dos grupos subordinados e a vida estatal é concebida como uma contínua formação e superação de equilíbrio instável (no âmbito da lei) entre os interesses do grupo fundamental e dos grupos subordinados, equilíbrio em que os interesses do grupo dominante prevalecem, mas até um determinado ponto, ou seja, 
não até o estreito interesse econômico-corporativo. (GRAMSCI, 2000, p.41-42)

Um importante indicativo da relação do Regime Ditatorial com o Esporte é o aparelhamento do estado com atores que estavam hora dentro da gestão pública, hora dentro de Federações e entidades desportivas, quando não exerciam funções concomitantes. A exemplo citamos casos ocorridos no Estado de São Paulo: Laudo Natel, que foi dirigente do São Paulo Futebol Clube durante a construção do estádio do Morumbi, e assumiu, alguns anos depois, cargo primeiro como vice-governador e depois governador do estado de São Paulo; José Maria Marin, que durante mandato de deputado estadual pela Arena, foi o penúltimo governador do Estado de São Paulo indicado pela ditadura militar e exerceu mandato entre 1982 e 1983, sendo que no mesmo ano passou a dirigir a Federação Paulista de Futebol, em mandato que foi até o ano de 1988; Wadih Helu, arenista que exerceu mandato como deputado estadual, foi presidente do Esporte Clube Corinthians durante os anos de 1961 a 1971, e foi secretário de estado durante o governo de Paulo Maluf, entre os anos 1979 e 1982 e Adhemar de Barros, que já possuía ligação anterior ao Regime Militar com o esporte, havia sido responsável pela construção do estádio do Pacaembu no seu período como interventor federal, nomeado por Getúlio Vargas durante o Estado Novo, em 1940, em parceria com o prefeito do município de São Paulo, Prestes Maia, e procedeu com sua expansão durante o seu mandato como governador do Estado de São Paulo, entre os anos de 1963 e 1966.

\subsection{Esporte X Ditadura}

O esporte foi um tema muito caro para o governo militar, que o tinha como um dos vetores de reconhecimento do país que se pretendia forte no cenário mundial (OLIVEIRA apud DEL PRIORE, 2009). Houve investimentos tanto no esporte escolar, esse voltado para o controle social e garimpo de atletas, quanto no esporte amador $\mathrm{e}$ de alto rendimento. Taborda Oliveira exemplifica a ação do governo militar fazendo referência a existência em quase toda cidade brasileira de um estádio esportivo batizado com o nome e algum ex-militar (a nomeação, nesse caso, serve tanto para fazer-se presente quanto para mostrar permanentemente à população quem fora 0 responsável pela obra) (Id., p. 387). Para nós, esse exemplo é bastante pertinente, 
devido ao levantamento de fontes da nossa pesquisa, que nos mostrou a quantidade de quadras e ginásios construídos no estado de São Paulo no período de 1964 a $1972^{3}$.

O autoritarismo da ditadura militar e a busca pelo que fosse de fato "nacional" era um produto próprio da cultura política brasileira. Essa busca sobre o que era nacional pretendia uma padronização própria dos governos autoritários, por mais que se embasasse, muitas vezes, em discursos de ordem progressista. Reconhecendo o esporte como fenômeno cultural universal, submetido a possibilidade de padronização que culminaria no reconhecimento de um modo nacional, que mostrasse a "potência" do Brasil nos embates esportivos internacionais, e que simbolizasse capacidade de enfrentar problemas internos e se projetar internacionalmente (Id., 2012, p. 159).

No contexto do pós guerra, o esporte como marcador de desenvolvimento de desenvolvimento econômico e civilizatório para os países - devemos considerar que as duas potências da época, EUA e União Soviética, se alternavam como maiores vencedoras em competições internacionais, sobretudo nas Olimpíadas. Foi um momento em que o esporte cumpria um papel de significar a existência nacional, em um mundo altamente nacionalista (OLIVEIRA, 2009, p. 388). Eventos como as Olimpíadas e as Copas do Mundo de Futebol passaram a ter especial atenção do governo militar, não só em âmbito federal, mas também nos estados.

Por ocasião do tricampeonato brasileiro na Copa do Mundo, os discursos nas casas legislativas e no Governo passaram a usar a vitória nas discussões, mostrando o resultado como fim de uma política pública eficiente nos esportes. A vitória do Brasil virou analogia, motivação, fim e meio. O Tribunal de Contas de São Paulo, através de pronunciamento do conselheiro Nicolau Tuma, fez uma nota de júbilo à conquista: "a vitória alcançada foi altamente significativa para o Brasil, não somente no setor esportivo, mas também sob o aspecto cívico, pois demonstrou que a nação pode vibrar em uníssono", e o presidente completou associando o resultado a uma política desenvolvimentista,

o Presidente ressaltou que a vitória brasileira, mais do que um feito esportivo, é um índice do desenvolvimento nacional, uma

\footnotetext{
${ }^{3}$ Só no primeiro ano foram 102 quadras esportivas escolares espalhadas pelo interior do estado.
} 
vez que o esporte é uma das expressões da cultura de um povo. Afirmou ainda S.Exa., que país nenhum do mundo pode sobressair-se em qualquer campo se não estiver alicerçado numa dinâmica desenvolvimentista (SÃO PAULO, 1970, n. 121).

Durante todo o mês seguinte à Copa do Mundo, houve na Câmara Municipal de São Paulo (CMSP) e na Assembleia Legislativa do Estado de São Paulo (Alesp) diversos pronunciamentos e discursos sobre a vitória do Brasil, sempre associando a conquista a questões cívicas, a elogios ao governo "Revolucionário", à importância do investimento no esporte, ao nacionalismo, à religião e ao "aprimoramento da raça brasileira".

Em julho de 1970, o prefeito da capital, Paulo Maluf, levou à votação da CMSP o projeto que ficou conhecido como "Projeto Volkswagen", que consistia na compra de fuscas para os jogadores e técnicos da seleção brasileira de futebol. O único voto contrário, do vereador Sampaio Doria, foi retirado na primeira discussão. (SÃO PAULO, 1970, n.124)

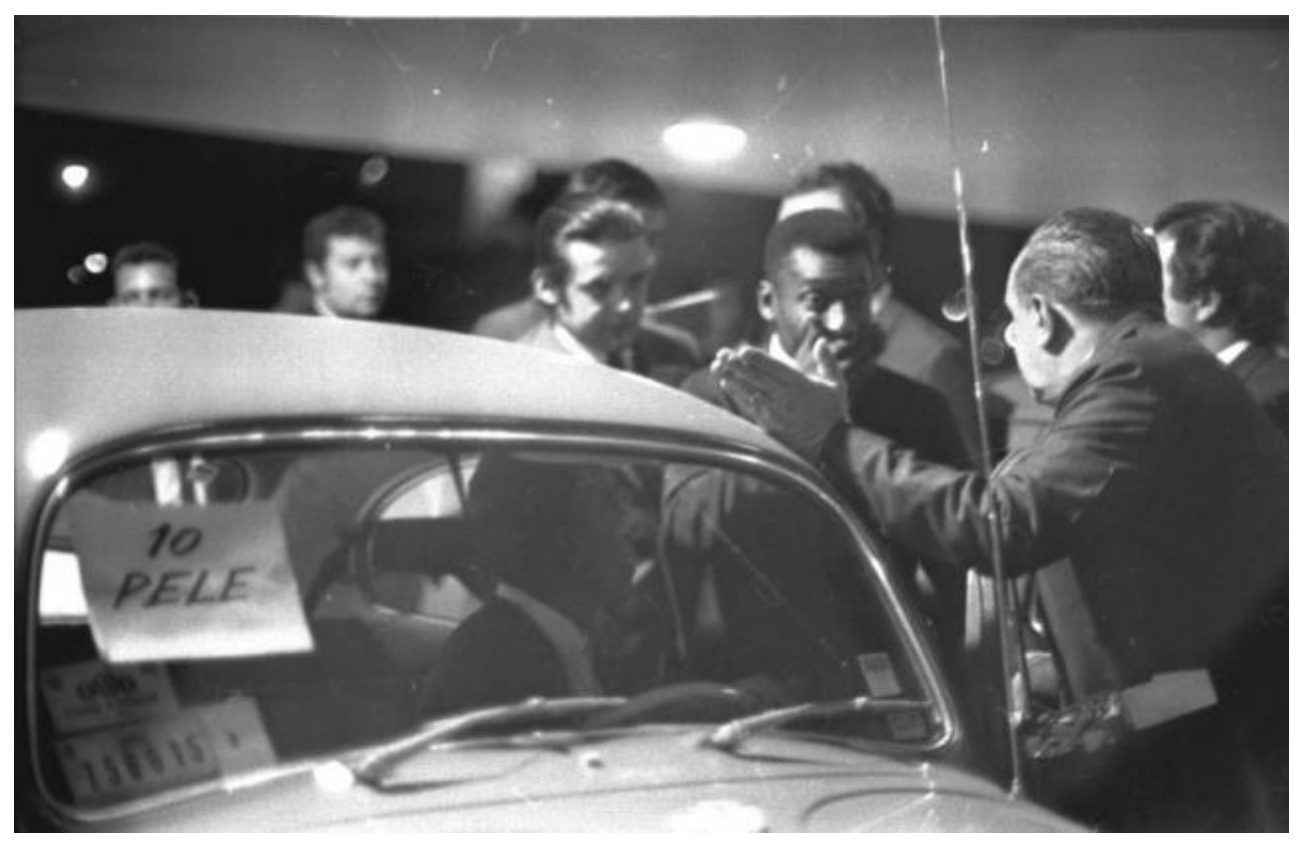

Figura 1 - Pelé e o Fusca que ganhou. Acervo Estadão. Foto: José Pinto/Estadão. 
Logo após a Copa do Mundo a questão nacionalista ficou aflorada por bastante tempo e foram apresentados diversos projetos e indicativos seguindo essa linha. Como exemplo, citamos a moção do deputado Ary Silva endereçada ao Ministro da Educação, propondo que fosse feita uma regulação determinando que os selecionados brasileiros de todas as modalidades passassem a usar no uniforme a bandeira do Brasil, e não mais os símbolos das entidades às quais eram filiados. (SÃO PAULO, 1970, n. 160)

Segundo Taborda (2012), o período de governo militar foi marcado pela discussão do que seria "nacional/autêntico", em um mundo marcado pelo "nacionalismo", e em que as contendas internacionais que poriam à prova o valor dos países passa, além das vias bélicas, por competições esportivas.

Mas essa forma de afirmação da autoestima de uma nação corria paralela à outra, aquela que procurava (e ainda procura) capturar a "sensibilidade das massas" em um esforço de afirmação política que lançava mão da cultura - e da sua propaganda - como veículo para a produção de uma identidade comum. (Id., p.157)

O esporte teve o papel de fomentar essa "identidade comum", e esse papel foi amplamente cobrado do governo, que ora usava desse viés possível dentro do campo esportivo para propaganda de governo, a fim de atingir a "sensibilidade das massas", ora atendia pressão social/civil por ações no campo esportivo. Em São Paulo, a prefeitura passou a custear a Olimpíada Colegial, visando o caráter nacionalista que era atribuído ao esporte, o que fica claro com a escolha da data para a realização dos Jogos Colegiais, além da retomada da organização do evento por parte do estado,

Essa autêntica Olimpíada Colegial, [...] está a merecer do legislador bandeirante um justo e amplo elogio. Não se trata, como a princípio se poderia pensar, de uma simples competição esportiva. Tem um significado muito mais profundo. [...]. Tal olimpíada passou novamente a ser patrocinada pelo DEFE, depois de nove anos de alheamento do poder público [...]. Se no passado nos destacamos pelo menos no panorama sulamericano [...] isso se deveu a iniciativas do DEFE, [...] como acontece em todos os países do mundo onde o homem público 
compreendeu o valor do esporte na preservação da raça. (SÃO PAULO, 1964, n. 174)

É interessante registrarmos que, após essa fala de caro caráter nacionalista, a discussão apresentada em seguida nesta sessão na Alesp dizia respeito a apresentação de dossiê sobre atividades comunistas no interior do estado, e pedia providências do governador. 


\section{CAPÍTULO II}

\subsection{Educação em tempos de ditadura}

Para que possamos partir para objeto de nosso estudo, carece-nos contextualizar quais foram as políticas educacionais empregadas pelo Estado Militar Brasileiro no campo da educação e particularmente da educação física. Cabe dizer que por política educacional entendemos "conjunto de medidas tomadas (ou apenas formuladas) pelo Estado e que dizem respeito ao aparelho de ensino (propriamente escolar ou não)". (CUNHA, 1983)

Sabemos que uma das principais funções de um estado capitalista é qualificar e preparar a força de trabalho e promover a reprodução do modelo de sociedade vigente (LENHARDT; OFFE., 1984), e para tanto fica a cargo do estado se ocupar do sistema de ensino. Sendo assim, as políticas educacionais empregadas pelo Estado Militar foram direcionadas para o emprego do tecnicismo nas escolas e do ensino profissionalizante.

Apesar dos recursos empregados no sistema educacional, o governo militar demorou quatro anos até estabelecer alguma mudança significativa frente ao modelo usado antes do Golpe de 64, começando pela reforma universitária, mostrando que a política educacional não foi, a priori, grande prioridade no governo.

Segundo Germano (1990),

é preciso lembrar que se trata de um Estado situado na periferia do capitalismo e que assumiu uma forma de ditadura militar, excludente com relação ao setor popular (e seus aliados) e altamente integrado com o grande capital, cujas prioridades situavam-se na esfera dos "grandes empreendimentos".

A intensificação da atuação institucionalizada do governo no sistema educacional foi concomitante ao estabelecimento do Al-5, de dezembro de 1968. Em novembro de mesmo ano, com as Leis 5.540 e 55.398, o governo militar estabeleceu a reforma universitária, e através dela o controle político e ideológico de alunos e professores, procurando cooptar segmentos das classes subalternas para seu projeto de poder. 
Para contextualizarmos, o ano de 1968 foi marcado por forte mobilização popular contra o regime, organização dos movimentos estudantis e de trabalhadores, logo, o Ato Institucional e a Reforma Universitária foram respostas extremas do governo de supressão desses movimentos e organizações.

Deve ser ressaltado que, muito embora as atribuições tradicionalmente imputadas ao setor educacional (como, qualificação, integração, socialização, equalização social e substituição de funções) apontem no sentido da reprodução social, nem por isso deixa de existir, nas escolas e universidades, um potencial crítico e contestatário que pode, segundo Habermas, "conduzir a conflitos desestabilizadores para o sistema". (Id., p. 138)

Como todo estado autoritário, apesar do aparelho militar a disposição da manutenção do status quo, foi necessário que a hegemonia se fizesse também por adesão de diversas camadas da sociedade, antagônicas entre si, buscando pares nas elites e apoiadores nas camadas populares. Sendo assim, a política educacional cumpria uma dupla função, a de preparar a mão de obra e a de educar as parcelas mais simples da sociedade para reproduzir de forma passiva o modelo social vigente.

Nesse contexto, a atuação do Estado na área da educação coerente com a ideologia de segurança nacional - vai se revestir e um anticomunismo exacerbado, de um anti-intelectualismo que conduzia à misologia, ou seja, à negação da razão, e mesmo ao terrorismo cultural. (Id., p. 143)

A reforma do ensino direcionou o sistema educacional para um modelo tecnicista de ensino, direcionado para a profissionalização, sem prezar pelo desenvolvimento de maiores capacidades intelectuais. O Estado Militar adotou a Teoria do Capital Humano ( $\mathrm{TCH}$ ), que priorizava a capacitação da mão de obra conforme as necessidades do mercado e do setor produtivo, visando muito mais o acúmulo coletivo que a oferta de oportunidades individuais. Segundo Schultz (1967, p. 18): 
Assim, educar significa, etimologicamente, revelar ou extrair de uma pessoa algo potencial e latente; significa aperfeiçoar uma pessoa, moral e mentalmente, de maneira a torná-la suscetível de escolhas individuais e sociais, e capaz de agir em consonância; significa prepará-la para uma profissão por meio de instrução sistemática; e, por fim, significa exercitar, disciplinar ou formar habilidades.

\subsection{Disciplina dos corpos, educação esportiva, moral e cívica}

Também a pauta de segurança nacional foi usada pelo Estado para justificar os interesses no Esporte, sendo o exercício do corpo tido como preparatório para soldados na defesa do país, sobretudo, defesa contra o comunismo, e a educação física como condicionante da aptidão física da população,

Uma abordagem analítica por intermédio desse tipo de mensuração, embora com imperfeições relevantes, torna viável uma primeira aproximação quanto ao rendimento do 'Sistema Educação Física/Desportos', observa em sua totalidade e na atuação sobre o fluxo populacional. No referente às atuais condições brasileiras, uma apreciação da aptidão física da população ainda é impraticável, sendo possível apenas reconhecimentos por meio de amostragens. Entre estas a mais importante e significativa é a representada pelos índices de incapacidade física para a prestação de serviço militar no Exército. (RIO DE JANEIRO, 1971, p. 311)

A disciplina dos corpos servia ao militarismo como meio de formar o cidadão dentro de uma perspectiva de saúde moral do corpo, corpo esse que estava a serviço da nação. A ditadura militar tinha um projeto de desenvolvimento da nacionalidade, que demandava disciplina do povo. O esporte, nesse contexto, funciona como ferramenta para formação ideológica, controle do corpo e do tempo livre da população. Ordem era a palavra-chave. O objetivo era a criação do cidadão a serviço do estado, de corpo e mente sãos e disciplinados capazes de servir a nação e manter o corpo social harmônico.

Assim, podemos ressaltar o caráter educativo do estado, e ainda, aplicando esse viés pedagógico ao âmbito dos esportes enquanto política pública, podemos nos basear na afirmativa de Gramsci quando ele diz que é papel do Estado "[...] adequar a 'civilização' e a moralidade das mais amplas massas populares às necessidades do aparelho econômico de produção e, portanto, de elaborar também fisicamente tipos 
novos de humanidade" (2000, p. 23). Durante esse período, a associação da prática esportiva ao ideal de "melhoramento do corpo" foi amplamente utilizado pelos governantes e legisladores.

Michel Foucault (1979, p. 172) dizia:

Mas nunca a disciplina foi tão importante, tão valorizada quanto a partir do momento em que se procurou gerir a população. $E$ gerir a população não queria dizer simplesmente gerir a massa coletiva dos fenômenos ou geri-los somente ao nível de seus resultados globais. Gerir a população significa geri-la em profundidade, minuciosamente, no detalhe. A ideia de um novo governo da população torna ainda mais agudo o problema do fundamento da soberania e ainda mais aguda a necessidade de desenvolver a disciplina. Devemos compreender as coisas não em termos de substituição de uma sociedade de soberania por uma sociedade disciplinar e desta por uma sociedade de governo. Trata-se de um triângulo: soberania-disciplina-gestão governamental, que tem na população seu alvo principal e nos dispositivos de segurança seus mecanismos essenciais.

Segundo ele, desde o século XVIII, fora constituído um conjunto de saberes sobre o corpo, e que foram usados em frentes distintas, buscando discipliná-lo e examiná-lo, por meio de instituições como as escolas e prisões, gerindo o modo como os indivíduos se comportam e gesticulam na expressão de seus anseios e desejos. Esse controle dos corpos se deu tanto dentro do poder constituído pela ideia de Estado quanto no que ele chama de poder em sua dimensão capilar,

Mas quando penso na mecânica do poder, penso em sua forma capilar de existir, no ponto em que o poder encontra o nível dos indivíduos, atinge seus corpos, vem se inserir em seus gestos, suas atitudes, seus discursos, sua aprendizagem, sua vida quotidiana. (Id., p. 161)

Em seu célebre livro História da sexualidade: a vontade de saber (2010), Foucault nos mostra como a partir do século XIX a gestão e disciplina dos corpos constituiu uma importante preocupação política de controle da população. O poder do Estado constituía-se também na capacidade de controle da natalidade e mortalidade, além de espaço de atuação destes corpos, tendo a vida do proletariado se tornado bem administrável. 


\begin{abstract}
Para que o proletariado fosse dotado de um corpo [...],foram necessários conflitos (especialmente com respeito ao espaço urbano: [...] ); foram necessárias urgências de natureza econômica (desenvolvimento da indústria pesada, com a necessidade de uma mão-de-obra estável e competente [...];foi necessária, enfim, a instauração de toda uma tecnologia de controle que permitia manter sob vigilância esse corpo[...] (a escola, a política habitacional, a higiene pública, as instituições de assistência e previdência, [...] ele já não corria o risco de desempenhar um papel de afirmação de classe em face da burguesia; continuava instrumento de sua hegemonia). (Id., p.118-119)
\end{abstract}

A ginástica e o exercício físico passaram a ser considerados ferramentas de obtenção de códigos civilizatórios, sendo cientificamente comprovado que sua prática proporcionava a eliminação de excessos do corpo e educação gestual que culmina na beleza e disciplina dos movimentos. Tudo isso era possível através da prática desportiva que constituía técnicas especiais do uso da força e habilidade física. Essa almejada beleza gestual revelava o caráter moral do indivíduo, que a partir do desenvolvimento do capitalismo e da burguesia ligava-se a questões de saúde e higiene. A prática desportiva desenvolvia o indivíduo para a sua atuação na própria sociedade (SOARES, 2005).

Carmem Lucia, em artigo que dialoga com Michael Foucault, faz uma análise de modos de ensino contemporâneos que controlam os desejos dos indivíduos, promovendo a busca do corpo perfeito, da saúde e incentivando proatividade, promovendo o lazer ativo e competitividade, em detrimento do divertimento, a não ser o passivo, promovido pelas propagandas, inclusive as de governos, e legitimada pelo discurso médico da saúde, dentro de uma perspectiva de cientificidade. Sendo assim, o indivíduo passou a buscar tirar o máximo de proveito do corpo (SOARES apud SOUSA, 2015).

A título de contextualização, a preocupação dos militares com as práticas esportivas remota de tempos anteriores ao período de Ditadura Militar. Em 1932, durante governo de Getúlio Vargas, o Ministro de Estado da Guerra, o General José Fernandes Leite de Castro, promulgou o Decreto 21.324/32, que regulamentava a disciplina da educação física e recomendava sua expansão das escolas militares para 
o estabelecimentos de ensino civis (CASTRO, 1997). Segundo o antropólogo Celso Castro, a medida gerou forte resistência de setores da Igreja e de educadores civis, sendo que somente em 1934, durante a gestão de Gustavo Capanema no Ministério da Educação e Saúde Pública (MES), que a educação física passou a ser prática institucionalizada no ensino. Contudo, a constituição de 1937 previu pela primeira vez na história do país a prática da educação física em toda rede de ensino.

A educação physica, o ensino civico e o de trabalhos manuaes serão obrigatorios em todas as escolas primarias, normaes e secundarias, não podendo nenhuma escola de qualquer desses gráos ser autorizada ou reconhecida sem que satisfaça aquela exigência. (BRASIL, 1937)

Tal designação era justificada pela necessidade de moralização da juventude e preparação do corpo para eventuais obrigatoriedades de defesa na nação e para promoção dos deveres do indivíduo com a economia,

O Estado fundará instituições ou dará o seu auxilio e protecção às fundadas por associações civis, tendo umas e outras por fim organizar para a juventude periodos de trabalho annual nos campos e officinas, assim como promover-Ihe a disciplina moral e o adestramento physico, de maneira a prepará-la ao cumprimento dos seus deveres para com a economia e a defesa da Nação. (Id.)

Contudo, a educação física se consolidou como disciplina somente em 1961, com a Lei de Diretrizes e Bases da Educação (BRASIL, 1961), publicada durante o governo João Goulart e direcionada a crianças e adolescentes até 18 anos. Vale ressaltar que São Paulo investiu na educação física escolar antes da obrigatoriedade dada pelo governo federal. 


\section{Díáro Oficial ESTADO DE SAO PAULO - (ESTADOS UNIDOS DO BRASIL)}

Diretor: WaNdxck FREitis

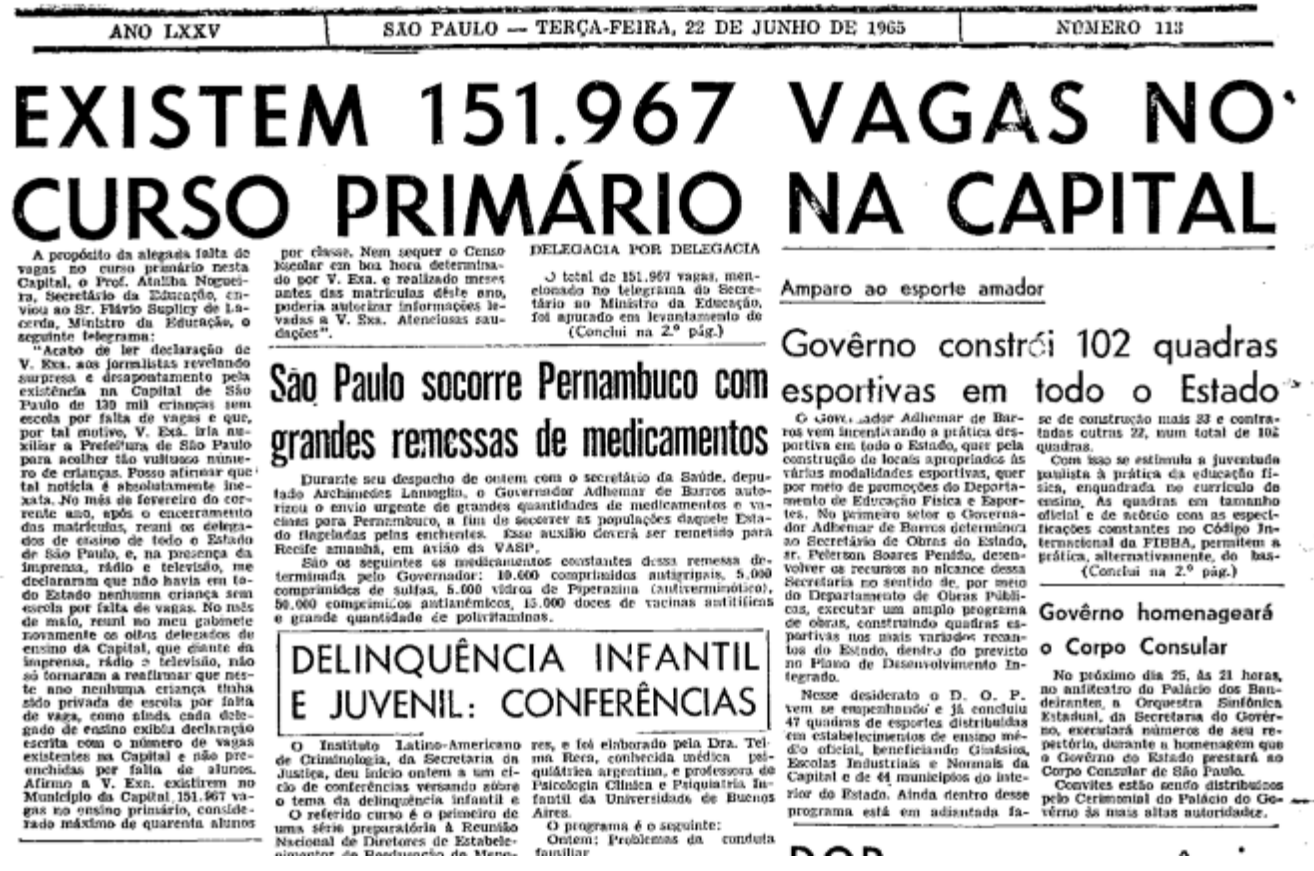

Figura 2 - Capa do Diário Oficial de 22 de junho de 1965. Note-se o destaque dado para a infraestrutura que teria a Educação Física junto a Educação Formal.

A regulamentação desta lei veio em 1966, definindo os métodos para a aplicação da prática física e a necessidade de assistência médica aos praticantes, sendo que a preocupação que levou os militares a regulamentar legislação estabelecida antes do golpe de 1964 fora a preocupação com a incapacidade física para o serviço obrigatório nas Forças Armadas, conforme já citado no Diagnóstico da Educação física/Desportos no Brasil.

Durante o governo do General Emilio Garrastazu Médici, foi publicado o Decreto 69.450, em novembro de 1971, que modificava a LDB de 1961, abrangendo a prática desportiva também para o ensino superior,

educação física, atividade que, por seus meios, processos e técnicas, desperta, desenvolve e aprimora forças físicas, morais, cívicas, psíquicas e sociais do educando, constitui um dos fatores básicos à conquista das finalidades da educação brasileira nacional. (BRASIL, 1971) 
O decreto também diferenciava o conteúdo que deveria ser ministrado em cada nível de ensino, o que esclarece qual era a proposta pedagógica que estava sendo implementada por meio da prática desportiva. No ensino primário a prática de exercícios visava à formação da personalidade do educando dentro da perspectiva da educação moral e cívica, visando formar o indivíduo dentro dos padrões considerados aceitáveis, com preceitos católicos e nacionalistas, com claro caráter doutrinário,

atividades físicas de caráter recreativo, de preferência as que favoreçam a consolidação de hábitos higiênicos, 0 desenvolvimento corporal e mental harmônico, a melhoria da aptidão física, o despertar do espírito comunitário da criatividade, do senso moral e cívico, além de outras que concorram para completar a formação integral da personalidade (Id., Art. I).

No ensino secundário, a metodologia empregada visava controlar o tempo livre dos alunos, a fim de não desvirtuar a educação obtida através do Estado durante o ensino primário, além de prosseguir com a almejada preparação da aptidão física que seguiria com o serviço obrigatório no Exército,

no secundário, por atividades que contribuam para o aprimoramento e aproveitamento integrado de todas as potencialidades físicas, morais e psíquicas do indivíduo, possibilitando-Ihe pelo emprego útil do tempo de lazer, uma perfeita sociabilidade a conservação da saúde, o fortalecimento da vontade, o estímulo às tendências de liderança e implantação de hábitos sadios (Id., Art. II).

Quando o aluno chegava ao ensino superior, a prática do esporte continuava no viés de desenvolvimento da aptidão física, que serviria não apenas ao preparo para o serviço militar, mas também para o garimpo de atletas que passariam a compor os selecionados brasileiros que representariam o país em competições internacionais, cumprindo uma função propagandística para o governo, que tinha no esporte um meio de conseguir apoio interno da população e solidificar no exterior a imagem de país em desenvolvimento, buscando demonstrar o salto civilizatório que o Brasil dava sob a égide do governo militar, "em prosseguimento à iniciada nos 
graus precedentes, por práticas, com predominância, de natureza desportiva, preferentemente as que conduzam à manutenção e aprimoramento da aptidão física, à conservação da saúde, à integração do estudante no campus universitário à consolidação do sentimento comunitário e de nacionalidade" (Id., Art. III).

Buscou-se assim tornar a prática desportiva elemento presente no cotidiano da população, proporcionando para o estado o gerenciamento das massas através de uma pedagogia moral e do corpo. Essa diretriz foi amplamente pensada e elaborada para funcionar nos estabelecimentos de ensino, o que proporcionou também o aumento significativo dos equipamentos esportivos do estado, conforme trataremos adiante.

A prática do esporte canalizava as energias reforçando a disciplina, evitando questionamentos e assegurando o equilíbrio social harmônico conforme os interesses do governo, que visavam, num primeiro momento, a preparação nacional para o combate da ameaça comunista, em num segundo, o preparo para a produtividade econômica (SOUSA, 2015).

\subsection{A educação física no estado de São Paulo}

\subsubsection{Governo Adhemar de Barros (1964-1966) - Foco em infraestrutura para o ensino do esporte}

Durante o período militar, o desporto e a educação física foram pautas corriqueiras nas demandas do governo e nas discussões nas câmaras legislativas do estado de São Paulo, abrangendo os âmbitos educacionais, de lazer e de entretenimento.

Em abril de 1964, a o Departamento de Educação lançou uma portaria (BRASIL, 1964) acatando representação feita pela Associação de Professores de Educação Física, juntamente com a Congregação da Escola de Educação Física, ambas as entidades de cunho estadual, para estabelecer na grade do Ensino Básico mais uma aula de Educação Física obrigatória. Essa portaria iria ao encontro dos atos executivos posteriores que autorizariam a construção de quadras nas escolas pelo Estado, visto que esse equipamento não era comum a todos os estabelecimentos de ensino. 
Relacionando o governador Adhemar de Barros ao Esporte, citamos uma publicação no Diário Oficial do Estado de São Paulo, que descrevia encontro realizado no dia 28 de abril de 1964, menos de um mês após o golpe que assolou o Brasil por 21 anos, entre o então governador e os esportistas paulistas,

Em cerimônia realizada ontem à noite nos Campos Elíseos, o Governador Adhemar de Barros foi homenageado pelos esportistas de São Paulo, homenagem essa que contou com a adesão de dezenas de presidentes de Federações esportivas de vários Estados do Brasil, também presentes à solenidade. A homenagem foi prestada ao Chefe do Executivo paulista pela sua atuação nos recentes acontecimentos que culminaram com a reimplantação da Democracia em nosso país. (SÃO PAULO, 1964, n. 80)

Nesta ocasião, o discurso do governador remeteu à questão de construção/melhoramento da "raça brasileira", "Contem comigo naquilo em que puder colaborar para o desenvolvimento da raça" (Ibidem). Vale ressaltar que os esportistas do Estado foram o primeiro grupo organizado a proceder com qualquer tipo de homenagem ao governador pelo apoio ao Golpe de Estado.

A devolutiva do governador aos esportistas fora substancial: só no primeiro ano de governo durante o regime militar, ele autorizou a construção de 102 quadras desportivas no Estado, das quais 33 foram autorizadas primeiro, sendo a construção prevista nas escolas da rede estadual (SÃO PAULO, 1964, n. 90); em seguida foram autorizadas outras 69, ambas com despachos publicados em 19 de maio de 1964 no caderno de Obras Públicas (ld., 1964, n. 92). O que se destaca na construção dessas quadras é que, nos três conjuntos de obras (33-48-21), a licitação foi ganha pela mesma empresa, Construtora Albuquerque e Takaoka Ltda., em processos presenciais licitatórios, nos quais não houve concorrentes. No mesmo período, em abril de 1964, também autorizou a construção do complexo esportivo do Ibirapuera com auxílio da Prefeitura de São Paulo, que seria mais tarde concedido ao II Exército (ld., 1964, n. 89).

Seguindo com a diretriz de construir quadras nas escolas públicas, em julho de 1964, o governador autorizou a desapropriação de terras em Itápolis para construção de Praça de Esportes para o Instituto Valentim Gentil (Decreto 13.518/61), e liberou 
verba para a Associação Atlética Samambaia, também para a construção de Praça de Esportes (Id., 1964, n. 131). 


\section{CAPÍTULO III}

\subsection{Políticas Públicas e Política de Esporte}

Antes de passarmos a elencar quais foram as ações tomadas pelos agentes públicos do Estado de São Paulo no campo esportivo, achamos necessário pontuar algumas questões quanto ao que entendemos sobre políticas públicas e políticas públicas de esporte.

Não existe consenso no campo da ciência política sobre a definição do conceito de políticas públicas, que vem constantemente sendo ressignificado. Contudo, para fins de entendimento do presente trabalho, buscaremos a intersecção de três definições, que nos parecem suprir, por ora, nossas necessidades explicativas.

Começamos pela definição de Souza (2006), que cunha política pública como sendo um conjunto de ações realizadas pelo Estado, visando o bem coletivo. Apesar de genérica, por não considerar as motivações que levam o Estado a realizar tais ações, nem quais são os componentes desse coletivo, essa nos parece bastante completa. Porém, precisamos de complementações, dado que essa conta com certo altruísmo por parte do Estado.

Seguimos para David Easton (1953), que diz que políticas públicas são um sistema de interfaces de ações que resultam em ações influenciadas diretamente por grupos de interesse. Sendo assim, as políticas públicas funcionariam como uma ferramenta de equilíbrio entre os conflitos dos grupos de interesses com o poder público - entendemos aqui grupos de interesses como grupos com interesses próximos e/ou semelhantes, mesmo que sua natureza seja antagônica, que se unem no intuito de reivindicar determinada demanda do Estado 4 .

Por último, seguimos com a definição de Thomas Dye (1984), que nos parece a que melhor se encaixa em um contexto de autoritarismo, para ele, política pública é

\footnotetext{
${ }^{4}$ Não iremos aqui nos aprofundar na questão dos grupos de interesse, devido a impossibilidade, por ora, de nos aprofundamentos na pesquisa prosopográfica de prosseguir com a prosopografia dos atores políticos do Estado junto às entidades de classe esportivas, imprensa e demais interessados nas ações listadas no decorrer do capítulo, devido ao fechamento do Arquivo Histórico do Estado, em decorrência da pandemia do covid19.
} 
o que o governo escolhe fazer ou não fazer $r^{5}$. Podemos dizer que, inclusive a omissão de ação é uma política pública de Estado.

Assim, propondo uma interface de conceitos que atenda a presente pesquisa, entendemos política pública como sendo: um conjunto de ações, que o Estado escolhe ou não fazer, visando melhorias na sociedade, de forma a atender interesses pontuais de grupos de interesses específicos, sendo ele próprio considerado um grupo de interesse.

Assim como Meily Linhales (1996), entendemos o esporte não apenas como elemento social submetido a interferências, mas como agente possuidor de autonomia, capaz de influir na vida cotidiana, inspirando comportamentos e valores.

Segundo Bracht e Almeida (2003, p. 87-101), a intervenção do Estado no esporte tem sido pautada, no Brasil, por duas ideias principais,

a. o esporte como instrumento de ação política no plano internacional (o desejo declarado por medalhas); b. a ideia de que a prática de esportes em massa é promotora da saúde e de uma melhor qualidade de vida da população, compensando os problemas advindos da vida urbana crescentemente tecnologizada, típico daquilo que caracterizamos como o Estado de bem-estar social.

Essas ideias nos parecem muito presentes nas ações adotadas pelo Governo Militar durante o período de da Ditadura. Com forme tratamos anteriormente, o esporte foi usado como ferramenta de projeção do Brasil como nação forte emergente no cenário internacional. A propaganda feita a partir dos ganhos esportivos dos selecionados brasileiros foi massiva, a fim de instituir no imaginário coletivo a ideia de um brasil próspero, ou como disse Oliveira (2012), "como se o desempenho esportivo de uns poucos significassem a dignificação da vida de todos". Segundo Oliveira,

Assim, pois, a apropriação da vitória do futebol brasileiro nos gramados mexicanos em 1970 é sintoma de uma operação que pretendia menos amainar os ânimos "revolucionários", como muito se supôs, e mais dotar um "povo" - algo já genérico, de

\footnotetext{
${ }^{5}$ Tradução nossa.
} 
invenção relativamente recente - de uma unidade de sentimentos brasileiros na arena política internacional. Se nas primeiras décadas do séc. XX se procurou construir a ideia de um "povo brasileiro", nos tempos da ditadura esse povo era, além do mais, um "vencedor".

Partindo para a segunda ideia que norteia as políticas públicas no campo dos esportes, que considera que a prática esportiva atuaria "[...] compensando os problemas advindos da vida urbana", acreditamos que em um contexto de governo autoritário, essa concepção justificou as ações do estado, que usaram o esporte, conforme já tratamos, para preencher o tempo livre do cidadão, doutrinar jovens em idade escolar e preparar corpos para o serviço militar.

\subsection{Panorama das ações governamentais no campo esportivo no estado de São Paulo}

Pensar o esporte como "correia de transmissão" de interesses políticos demanda a compreensão sobre o seu processo de institucionalização como política social, onde o Estado interfere diretamente na sua universalização.

Neste capítulo, elencaremos as ações do governo do Estado de São Paulo no campo dos esportes e traçaremos um panorama completo de todas as ações dos órgãos governamentais nesta área, no período de 31 de março de 1964 a 31 de dezembro de 1972.

Essa abordagem de caráter descritivo visa subsidiar a presente pesquisa para que possamos trabalhar posteriormente, de maneira aprofundada, quais as questões motivadoras das ações políticas que envolviam governo e esporte e a quais interesses e relações essas ações serviam. Para tanto, seguiremos com as ações dividas pelo exercício de mandato dos governadores do Estado dentro do período proposto apenas como forma de organização cronológica, visto que também trataremos de ações realizadas pela prefeitura de São Paulo e pelas casas legislativas do Estado e do município de São Paulo. 


\subsection{Ações do poder Executivo, ou que fizeram os governadores}

Seguiremos agora elencando as ações de ordem executiva de cada governador do Estado de São Paulo que teve mandado dentro do período proposto por nossa pesquisa, 164 a 1972.

\subsubsection{Governo Adhemar de Barros (1964-1966) - Estruturação}

Além da construção de quadras nas escolas estaduais, o governo também investiu em equipamentos de esportes independentes. Foi nesse período que muitas escolas estaduais tiveram suas quadras e ginásios construídos, e foi um período em que as casas legislativas propuseram de forma massiva a construção de equipamentos esportivos espalhados pelo estados. Sendo assim, entendemos este governo como um período de estruturação.

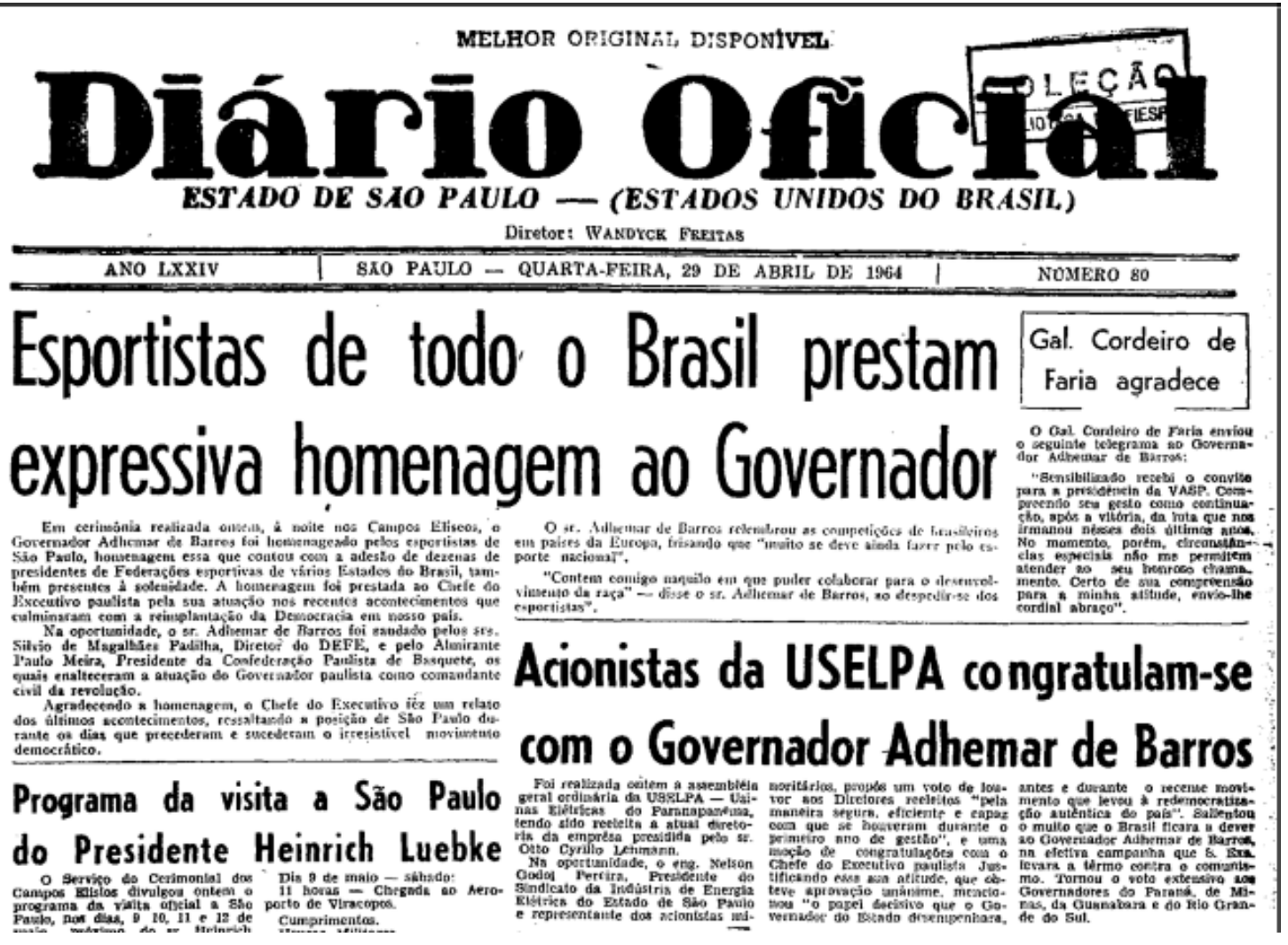

Figura 3 - Capa do Diário Oficial de SP de 29 de abril de 1964. A propaganda em torno do esporte gozava de visibilidade inclusive em documentos oficiais. 
Chama nossa atenção essa "expressiva homenagem ao governador" feita em um documento oficial. Não o bastante a adulação em torno da imagem do governador, a manchete nos mostra como o fazer público podia carregar um caráter paternalista, como se as ações do governo, que visavam oferecer as condições mínimas para a prática esportiva, fossem um presente pessoal do governador aos esportistas, e estes, por sua vez, prestavam essa expressiva homenagem em agradecimento ao favor.

Aproveitando o ensejo da predisposição do Executivo com os esportes, as câmaras legislativas do estado e do município de São Paulo apresentaram diversos projetos de lei para a construção de ginásios e estádios distritais, sendo sempre cada indicação condizente com a localidade da base eleitoral do parlamentar proponente. Somente em 1964, foram apresentados projetos de lei para a construção de ginásios e estádios distritais nas cidades de Presidente Prudente, Avaré, Araçatuba, e nos bairros paulistanos do Itaim Bibi, Vila Matilde, Vila Califórnia e Itaquera (SÃO PAULO, 1964, n. 149,177,198 e 206). O projeto dos ginásios estaduais na cidade de São Paulo foi vetado pelo governador em despacho que criticou a falta de planejamento para tal propositura (Id., 1965, n. 19). Além desse veto, também houve a negativa do projeto de lei 172/63, que teve parecer favorável após o golpe, que previa a criação de parque futebolístico estadual com quinhentos campos de jogo e cinco postos de assistência médica. Na justificativa para o referido veto Adhemar de Barros critica a falta de planejamento da viabilidade do Estado arcar com o gasto da implementação do parque,

Em diversas oportunidades já tenho feito sentir a esta Colenda Assembleia, a minha grande preocupação a propósito do hábito de se lançar sobre o Estado toda sorte de incumbência, sem que previamente se verifique a repercussão financeira da medida. (ld., 1965, n. 7)

Apesar da alegação de falta de recursos, no ano seguinte a Assembleia Legislativa voltou a apresentar projetos para a construção de ginásios e estádios distritais, muitos dos quais concretizaram-se posteriormente. No total foram apresentados mais doze projetos de lei, sendo eles destinados às cidades de Jundiaí, Campos do Jordão, Campinas, Valinhos, Paulínia, Vinhedo, Pedreira e Santa Barbada D'Oeste, Bragança Paulista, Marília, Itapetininga e para o bairro paulistano da Água 
Fria (Id., 1965, n. 49, 96, 105, 113, 115, 145 e 238). Também houve um projeto de lei de cunho mais generalista, que visava a construção desses equipamentos por região do interior do estado, apresentado pelo deputado Ciro Albuquerque. No município de São Paulo, os vereadores também apresentaram projetos parecidos endereçados ao prefeito Faria Lima, como o pedido para construção de estádio distrital na Lapa, formalizado pelo vereador Jayme Rodrigues (Id., 1964, n. 160).

Em setembro de 1964, o deputado Valério Giuli se pronunciou na Assembleia para tratar da falta de recursos do Departamento de Educação Física e Esporte DEFE, que segundo ele tinha por objetivo "prestar ajuda tão reclamada por todas as entidades esportivas amadoras" (Id., 1965, n. 171), contudo, sabemos que as atribuições do departamento extrapolavam as demandas das entidades.

Logo em seguida, o deputado Paulo Planet Buarque fez o mesmo pedido, ocasião na qual elogiou o acontecimento das Olimpíadas Colegiais, promovidas pelo governo do estado, fazendo-o na figura do major Sylvio de Magalhães Padilha, diretor do DEFE,

[...] com participação de vinte mil colegiais, o Campeonato Colegial da Semana da Pátria que trouxe para o Estádio do Pacaembu dois mil estudantes [...]. Uma realização notável do Departamento de Esportes e Educação Física do Estado, à testa do qual se encontra esse monumento dos desportos brasileiros, esse organizador ímpar, esse dedicado às coisas esportivas da nossa terra, que é Sylvio de Magalhães Padilha. (Id., 1964, n. 174)

É importante notarmos nesta fala o "prestígio e apreço" dos quais gozava o major Padilha frente aos parlamentares. Ao longo de toda a documentação analisada, ele aparece como figura importante nas decisões e ações públicas dentro do campo dos esportes.

Em outubro, a Assembleia Legislativa discutiu no mesmo dia, de forma acalorada, dois projetos de cunho esportivo, um que previa abarcar crédito adicional ao esporte no estado (Id., 1964, n. 200), o qual teve parecer negativo e outro, de origem executiva, que pedia autorização para a Assembleia para conceder crédito do estado ao Comitê Olímpico Nacional (lbid.), para as Olimpíadas de Tóquio, o que nos mostra que, apesar da falta de recursos, o governo do estado contribuía para o projeto 
de políticas esportivas de cunho nacional. Sobre o orçamento para o DEFE, a falta de recurso foi novamente questionada pelo deputado José Felício Castellano em novembro de 1964 (Id., 1964, n. 213).

Ainda em 1964 foram criados dois centros de recreação e esportes no interior, nas cidades de Itapetininga e Santa Cruz do Rio Pardo (SÃO PAULO, 1964, n. 231 e 233), ambos mantidos e subordinados ao DEFE. Vale lembrar que logo em seguida foi apresentado projeto de lei pedindo a construção de ginásio distrital em Itapetininga, desconsiderando a inauguração desse centro.

Em março de 1965, o governo do estado publicou no Diário Oficial (SÃO PAULO, 1965, n. 48) a prestação de contas das ações do ano anterior em todos os temas de atuação do estado. No quesito esporte ressaltou-se, entre outras coisas, a realização dos Jogos Colegiais; o registro dos atletas do estado pelo DEFE (24765 esportistas registrados); atuação do Estado junto ao Comitê Olímpico Nacional para a preparação de atletas, principalmente no boxe; a realização do Festival de Várzea, que contou com 147 clubes; o intercâmbio entre o interior e o centro da capital, para promover "a troca de experiência e adestramento" (Ibid.); o encontro dos professores de Educação Física do estado para elaboração de plano pedagógico conjunto a ser aplicado nos estabelecimentos de ensino; as obras no conjunto do lbirapuera. Para 1965, na mesma publicação houve a previsão de mais obras no complexo do Ibirapuera e a construção de instalações para recreação infantil no interior do estado. Notamos nesta listagem quais as diretrizes dos gastos com esporte do estado daquele ano, que visava a formação de atletas, o alinhamento com o projeto nacional de esportes, além do mapeamento dos atletas e entidades desportivas.

Por ocasião da preparação para os IV Jogos Pan-americanos, a Câmara Municipal de São Paulo resolveu conceder ao major Sylvio de Magalhães Padilha o título de Cidadão paulistano. A proponente do requerimento de entrega do título foi a vereadora Dulce Salles Cunha Braga, que não poupou elogios ao major Padilha,

Padilha não é homem que se sustenta com os feitos épicos de sua juventude estudante. Não Ihe bastou ter sido um atleta multiforme que se destacou afinal no esporte-base. [...] homem perfeitamente realizado. Aprendeu a obedecer para depois comandar. [...] Hoje, Sylvio de Magalhães Padilha representa um manancial inesgotável de conhecimentos básicos para real proveito do Governo da República". (Id., 1965, n. 53) 
A fim de subsidiar o governo, Padilha, que era presidente do Comitê Olímpico Brasileiro, elaborou relatório lido durante a solenidade, e que nos mostra claramente quais as diretrizes tomadas para o esporte no país, e consequentemente no Estado de São Paulo,

Nada melhor do que a educação física e o esporte para darem uma unidade, disciplina, respeito aos regulamentos, espírito de equipe, de sacrifício, e tantas outras qualidades para a formação de um homem [...] para uma juventude rígida e apta para a luta em qualquer setor. (Ibid.)

Podemos notar nesta fala o claro caráter doutrinário atribuído à prática e ao ensino dos esportes. Seguindo com o pronunciamento, a vereadora aproveita a fala para fazer menção à comemoração de um ano da "Marcha da Família com Deus Pela Liberdade",

(Pela Ordem) - Sr. Presidente, como amanhã haverá missa na Catedral, às 18 horas, de comemoração do aniversário da grande Marcha da Família com Deus Pela Liberdade, de há um ano, em que a mulher de São Paulo, em 5 dias, conseguiu reunir um milhão de pessoas para protestar contra a corrupção, contra a exploração, em defesa de sua pátria contra o comunismo, em favor do regime democrático, pediria a V. Exa. Sr. Presidente, que enviasse as flores que ornamentam esta grande Sessão à Catedral". (lbid.)

O pedido da vereadora foi prontamente atendido, e nos parece bastante simbólico que as flores da solenidade em homenagem ao major Padilha ornamentassem no dia seguinte a referida missa.

Mesmo quando o governador era criticado por algum projeto ou ação no campo dos esportes, a crítica se dava de maneira particularmente branda, e sempre enaltecendo o seu papel na difusão do esporte no estado,

Quanto ao ginásio de Valparaíso, V. Exa. acusa o atual governo de tê-lo fechado, e é coisa que não podemos admitir de princípio, pois conhecemos o plano educacional tanto do ensino primário quanto do ensino secundário, ou do ensino colegial, [...]. E admiramos profundamente a obra do atual Governador de São Paulo, o eminente Brasileiro Adhemar de Barros, no campo educacional. (Id., 1965, n. 86) 
O pronunciamento acima foi feito pelo deputado Walter Arruda durante uma discussão sobre o ginásio de Valparaíso. Na fala do deputado fica atestada a construção de quadras no estado, o que deixa claro a ênfase do governo na propagação da Educação Física dentro do sistema de ensino.

Em maio de 1965, o governador Adhemar de Barros promoveu um novo encontro com os esportistas do estado, ocasião na qual anunciou auxílios e subvenções para as entidades desportivas. A mobilização de parte do alto escalão do governo para o evento com dirigentes esportivos mostra a necessidade do apoio político das Federações e entidades desportivas,

O Governador Adhemar de Barros homenageou ontem, com um almoço no Clube Paulistano, os dirigentes máximos dos esportes em nosso Estado, oportunidade em que assegurou total apoio às iniciativas visando o desenvolvimento das práticas esportivas em São Paulo. Estiveram presentes ao encontro os secretários da Fazenda, Educação, Governo, Obras e Turismo, [...], o Diretor do Departamento de Educação Física e Esportes, sr. Sylvio de Magalhães Padilha; membros do Comitê Olímpico Brasileiro, dirigentes de 35 federações esportivas e outras personalidades destacadas do esporte paulista. (SÃO PAULO, 1965, n. 94)

A pauta deste encontro foi debatida dias depois na Assembleia Legislativa de São Paulo, onde o deputado Lino José Saglietti esclareceu que a iniciativa de promover o encontro veio do major Padilha, e nele foram expostos os problemas e dificuldades para a promoção do esporte no estado. Além de ocorrer uma defesa da delegação de esportistas que voltaram das Olimpíadas de Tóquio, atribuindo o baixo desempenho à falta de investimentos públicos. Em seu pronunciamento, o deputado citou a fala do major, que expõe quais as diretrizes deveriam ser adotadas no esporte, e por quais motivações,

O debilitado panorama dos esportes em nosso país, cuja responsabilidade repousa nos poderes públicos nacionais, que não estimulam, e ao contrário, relegam para segundo plano essas atividades, enquanto países de mais expressão do mundo livre o estimulam nos colégios e nas universidades e os países de regime forte têm-no, não só como valor na formação de seu povo, mas como elemento de projeção e propaganda do regime. (ld., 1965, n. 97) 
A partir das fontes, notamos uma convergência de ações do governo do estado, da Assembleia Legislativa, da Prefeitura de São Paulo e da Câmara municipal para a ampliação do acesso ao esporte dentro do sistema escolar. Logo depois da reunião de dirigentes, foi apresentado na Assembleia projeto de lei que visava tornar obrigatório que houvesse local para a prática de esportes nos estabelecimentos públicos de ensino (Id., 1965, n. 106). Em seguida, em junho de 1965, a construção das 102 quadras (ld., 1965, n. 112) feitas pela construtora Albuquerque e Takaoka (obras que contaram com ajuste de preços) foi publicada como notícia na primeira página do Diário Oficial, "Apoio ao Esporte Amador - Governador Constrói 102 quadras esportivas em todo o Estado" (Id., 1965, n. 113), as obras ainda estavam em andamento.

Visando a integração com o Governo Federal, Paulo Planet Buarque apresentou projeto de lei para a subvenção de recursos do DEFE para a Confederação Brasileira de Desportos, para a preparação da seleção brasileira de Futebol para o Campeonato na Inglaterra (Id., 1965, n. 191).

Em nova discussão sobre o projeto de Ciro Albuquerque para a construção de equipamentos esportivos no interior, houve por justificativa para o projeto ênfase no caráter educacional do esporte. Segundo o deputado Chopin Tavares de Lima,

a concessão de auxílio ao esporte, que tem importância para a cultura, que V. Exa. (Ciro A.) atinge com perfeição, é fundamental para a educação de um povo, quer sob o aspecto físico, quer sob o aspecto de equilíbrio emocional e psíquico. [...]. Essas Praças de Esporte servirão, também para a educação cívica [...]. (Id., 1965, n. 234)

Após a realização dos Jogos Abertos do Interior debateu-se na Assembleia a concessão de verbas para as entidades amadoras de esportes no estado de São Paulo, ressaltando o caráter patriótico da prática esportiva,

[...] quem tem acompanhado [...] os Jogos Abertos do Interior, sabe avaliar bem o serviço que prestam à coletividade esportiva do Estado essas entidades amadoras. O Departamento de Educação Física, tão bem dirigido por essa grande figura do esportista [...] Major Sylvio de Magalhães Padilha. [...] ainda de forma restrita em quase todas as cidades do interior, por absoluta carência de recursos [...]. Então é de bom alvitre, de 
espírito sadio e patriótico defender os esportes amadores, principalmente quando nós sentimos o estoicismo, por não dizer, daqueles homens dirigentes do esporte amador do interior. (Id., 1966, n. 235)

\subsubsection{Primeiro governo Laudo Natel (1966-1967) - Transição}

Laudo Natel assumiu o governo do estado de São Paulo em junho de 1966, e permaneceu menos de um ano no cargo. Apesar do curto período, seu governo lidou com pautas importantes para a política de esportes do Estado, mudando o foco do governo anterior, que era voltado às construções e ao esporte educacional, para começar a pensar em questões tributárias, como a tentativa de criação da loteria esportiva estadual, além de pensar o esporte quanto entretenimento para a população. Pensando nessa mudança de postura, chamamos esse período de transição.

Logo em seu primeiro mês no cargo, apresentou à Assembleia Legislativa um pedido de autorização para abertura de crédito para a compra de videotapes da Copa do Mundo, em ação que acreditamos compor um projeto de propaganda do governo,

Acredito que o Governo Laudo Natel procedeu com todo acerto e sensibilidade ao submeter à aprovação da Assembleia abertura de crédito para a aquisição de "videotapes" da Copa do Mundo, permitindo assim que esse certame esportivo seja acompanhado não apenas por quem venha a ter o privilégio de ir à Europa, mas também por todos aqueles que aqui permanecem. (SÃO PAULO,1966, n.115)

Esta fala do deputado Jacob Carolo se iniciou enaltecendo a decisão de pedir autorização da Assembleia, o que para nós deu-se devido ao caráter excepcional do gasto. Em justificativa ao aprove do projeto, Carolo enalteceu o que ele chamou de "influência benéfica" do futebol para os brasileiros,

Os que a isso se opõem, ou fazem por uma atitude de sistemática oposição ou por ignorar a influência benéfica desse esporte na vida brasileira. [...]. O futebol é um agente popular que não encontra paralelo. Desde que se fundou a FIFA, em 1904, o futebol adquiriu papel relevante na recreação do povo. Por que negar ao povo a satisfação de acompanhar a Copa do 
Mundo, de palpitar com os nossos craques os grandes momentos de emoção? Enganam-se os que supõem que o povo não precisa de recreação. A recreação entra na vida do homem com a mesma importância da alimentação e da habitação. (lbidem.)

Apesar de aprovado o projeto que autorizava o governador a proceder com a compra, o debate na Assembleia se estendeu, e houve inclusive quem apontasse a compra dos videotapes da Copa como inconstitucional,

Como representante do povo, dentro de uma linha de coerência, tenho que situar-me em posição antagônica e antipática, até, à grande parcela da opinião pública. E o faço porque não posso fugir a um dever de zelar pelo patrimônio público, pois essa tem sido a constante de minha vida. A aquisição de "tapes" por um bilhão e quinhentos milhões, embora tenha sido justificada por ilustres cidadãos integrantes de órgãos de publicidade e ligados à vida esportiva do País, mesmo assim, entendo que a medida é inconstitucional, porque a própria constituição estabelece que a aquisição, por parte do Poder Público de qualquer objeto, deve ser feita através de concorrência pública. (SÃO PAULO,1966, n.119)

A fala anterior indica a possível pressão pública, sobretudo de órgãos ligados à imprensa esportiva, para que o governo procedesse com a compra desse material. Outro aspecto contrário apresentado frisava que o Estado deveria se ocupar do esporte educacional, em detrimento do entretenimento da população, inclusive usando o esporte no "melhoramento da raça", discurso esse recorrente durante as manifestações dos legisladores,

Creio que o Estado deve ajudar o esporte porque faz parte da formação da nossa própria juventude, mas a pura e simples aquisição de "videotape" não representa, de maneira nenhuma, o fortalecimento da raça. (Ibidem.)

O esporte permaneceu na pauta da Assembleia Legislativa como tema recorrente. Foi apresentado em agosto projeto de lei que visava a criação da loteria estadual, da qual os fundos seriam revertidos para as Santas Casas de Misericórdia. Segundo o deputado Paulo Planet Buarque, era inaceitável que o estado de São Paulo ainda não dispusesse dessa fonte de renda, ficando aquém de outros estados, 
Desejo associar-me ao aplauso relativo à iniciativa do Chefe do Executivo bandeirante. [...] tive a oportunidade de me pronunciar favoravelmente à iniciativa, porque, das duas, uma Sr. Presidente: ou o Governo Federal não permite a loteria em nenhum Estado da Federação, e muito menos a loteria federal, ou não se explica que o Estado de São Paulo esteja ilhado neste particular. Aqui é vendida a loteria do Estado de Minas, a loteria do Estado do Rio e até mesmo a loteria do Uruguai, representando uma evasão de renda do Estado enorme e sem nenhum benefício para o próprio estado de São Paulo. (SÃO PAULO, 1966, n. 146)

Entendemos por esse pronunciamento que o governo federal estaria colocando empecilhos para a criação da loteria. Vale ressaltar que o projeto foi de iniciativa do Executivo, e não de nenhum deputado em particular. Contudo, a discussão seguiu na direção de que, caso criada, os fundos da loteria não se destinariam somente às Santas Casas, como constava no projeto original, mas também ao esporte amador, seguindo a justificativa da necessidade de investimentos nessa área, o que já era feito em todo o mundo,

No entanto, é hoje motivo de admiração de nossa parte o incremento de praças de esportes, de utilização popular, que se observa nos países da Cortina de Ferro, altamente socializados, ou se observa nos Estados Unidos, através das universidades ou através de suas praças de esportes municipais e estaduais. Mas, em São Paulo, infelizmente, não há nenhuma iniciativa, neste particular, por parte do Governo. (Ibidem)

O governador Laudo Natel anunciou, em setembro de 1966 (SÃO PAULO, 1966, n. 163), a construção de 21 quadras no interior do estado, talvez em resposta aos constantes apontamentos de falta de recursos para o esporte.

Outro projeto importante discutido na Câmara de Vereadores de São Paulo sobre o esporte foi o PL 219/64, que pretendia sujeitar os Clubes profissionais da Cidade de São Paulo à legislação Fiscal do Município (Ato no 1159.36, art. 500 e 217), impondo cobrança de imposto cujo valor seria revertido ao esporte amador. Esse projeto encontrou muita resistência por parte dos vereadores, além de ataques ao prefeito Faria Lima,

Tenho em conta que para o Sr. Prefeito o esporte amador é uma frutífera fonte de rendas com destinação de interesse geral ainda desconhecido. É que a todo instante S. Exa. autoriza a 
majoração de ingressos, como vem de fazer agora, [...] (SÃO PAULO, 1966, n. 160)

Segundo o deputado Francisco Moraes, não havia sentido em autorizar constantemente $\mathrm{o}$ aumento do valor dos ingressos cobrados pelos clubes profissionais nos estádios públicos, se o lucro desses não fosse tributado, sendo que ele sugeriu imposto de $15 \%$ sobre o valor do ingresso. Durante a última discussão sobre o PL, o vereador Ary Silva pontua que os clubes já têm auxílios voltados para o esporte amador, diz que a Câmara já concedeu, em outra oportunidade, recursos ao Conselho Municipal de Esportes, e ainda alega que os prejudicados seriam os que costumam ir aos estádios, que teriam que arcar com o aumento do preço dos ingressos (SÃO PAULO,1966, n. 115). A discussão se estendeu até o ano seguinte.

Em setembro de 1966, o governador enviou mensagem à Assembleia que tratava de concessão de auxílio financeiro à Prefeitura de Rio Claro, por sediar os Jogos Abertos do Interior, e foi duramente criticado pelo deputado José Lurtz Sabia, não pela proposição, mas por não a ter apresentado em caráter de projeto de lei para a concessão de auxílio a todas as cidades que viessem a sediar os jogos, acusandoo de fazer uma manobra de cunho eleitoreiro, apenas,

o Sr. Governador do Estado deveria estabelecer em mensagem uma lei que pudesse oferecer auxílio ou subvenção a todas as prefeituras, a todos os municípios onde foram realizados jogos abertos. Assim a medida geral será muito mais acertada para que não fique apenas sendo de atendimento a determinadas pretensões políticas e até eleitorais. (Id., 1966, n. 180)

Em 17 de setembro de 1966, foi discutido na Câmara Municipal de São Paulo o projeto de lei que dispunha sobre a organização do Departamento Municipal de Esportes. Também na Câmara houve em outubro a visita do Presidente da República, General Castelo Branco, ocasião em que o vereador Marcos Melega declarou seu apoio à "revolução" para em seguida denunciar práticas do MBD,

Meu discurso hoje é um diálogo, em voz alta, com o Sr. Presidente da República. Faço-o, em primeiro lugar, como cidadão brasileiro; em segundo, como um revolucionário autêntico; em terceiro, como líder da ARENA nesta Casa, partido político esse que encerra os princípios vitais da Revolução de 31 de março de 1964. (ld., 1966, n. 202) 
Neste discurso, o vereador acusou membros do MBD ligados à Federação Paulista de Futebol de usarem a instituição para fazer compra de votos no interior do estado,

\begin{abstract}
Assim, há dias trouxe ao conhecimento da opinião pública [...], fato gravíssimos de corrupção eleitoral quem vêm sendo praticados pela Federação Paulista de Futebol. Sei de fatos que envergonham: a compra de votos, Sr. Presidente da República, com a deturpação de caráter daqueles brasileiros que se dispõem à prática desse nobre esporte. Compram voto, Sr. Presidente da República, com uma camisa ou com uma chuteira. (Ibidem)
\end{abstract}

A mesma denúncia foi feita na Assembleia Legislativa pelo deputado Hélio Mendonça, que acusou o deputado João Mendonça Falcão, então presidente da Federação Paulista de Futebol, de usar a máquina da federação para comprar votos no interior do estado para a sua reeleição, prometendo aos clubes vagas na divisão especial da Federação Paulista, diplomas para juízes e outros benefícios ilícitos. Cita um bilhete que recebeu no qual havia escrito o seguinte:

Prova de corrupção. Como se vê pelo jornal, o João Mendonça Falcão anda dando diplomas de juízes de futebol para aqueles que votarem nele e passará os clubes para as divisões superiores se também trabalharem para ele nas eleições futuras do dia 15 de novembro. (Id., 1966, n. 205)

Junto à denúncia, foi entregue matéria de jornal Diário de Rio Claro que servia como prova da compra de votos,

Comentarista craque. Hoje estamos focalizando foto do Sr. João Mendonça Falcão, Presidente da Federação Paulista de Futebol e Vice-Presidente da Assembleia Legislativa de São Paulo, um homem público que muito tem feito para o esporte de São Paulo e para o Interior. Atualmente, o mandatário federacionista está em campanha pelo Interior, visando sua reeleição, como deputado estadual [...]. Todos os esportistas de nossa cidade, bem como os diretores de clubes filiados à entidade máxima [...] devem trabalhar para 0 deputado Mendonça Falcão, principalmente os diretores do "Azulão" que [...] terão a possibilidade [...], de preencher uma das 16 vagas que existem na $2^{\mathrm{a}}$ Divisão de profissionais. (Ibidem) 


\subsubsection{Governo Abreu Sodré (1967-1971) - Normatização}

Durante o governo Abreu Sodré, houve uma tendência do poder público, tanto Legislativo quanto Executivo, de produzir legislação acerca do esporte. Foi criada na Alesp a Comissão de Esporte que deu andamento ao debate de diversos projetos de lei sobre o tema, e por isso entendemos que foi um período de normatização.

A tendência de se investir em equipamentos continuou durante o governo de Abreu Sodré, não apenas no Estado de São Paulo, mas também na capital. Em maio de 1967, o vereador Francisco Batista faz indicação ao prefeito de São Paulo para que ele ajude os clubes amadores da cidade a construir e ampliar suas sedes municipais, pedindo inclusive que a destinação dos recursos oferecidos pela municipalidade para este fim ficasse a cargo dos dirigentes.

Indico ao Exmo. Sr. Prefeito Municipal se digne a estudar [...] a efetiva ajuda financeira aos Clubes Amadores de nossa Capital, que possuam no mínimo vinte anos de existência para a construção ou ampliação de suas sedes, favorecendo assim os [...] verdadeiros fomentadores dos esportes no Brasil. [...] De outro lado, em nada tem adiantado o controle pelo poder público, que somente cria fatos burocráticos, devendo deixar a livre critério das Entidades a real aplicação do dinheiro. (SÃO PAULO, 1967, n. 80)

No âmbito estadual, a Assembleia legislativa voltava a discutir formas de fomentar o esporte amador, e houve nova discussão sobre a criação da loteria estadual, que teria sua arrecadação destinada às Santas Casas e ao Esporte (Id., 1967, n. 82), e sobre a criação de uma comissão de esportes na casa. Contrário ao projeto, o deputado Orlando Jurca faz fala contrária à criação da Comissão,

Assim é que o regimento desta casa apresentado pela douta Mesa propõe a criação de Comissão de Esporte [...]. até parece que estamos vivendo num verdadeiro paraíso, num Xangri-lá, onde se apresenta um projeto propondo a criação de Comissões de Esporte e Turismo, específicas. [...] A Assembleia que não tem Comissão específica para o ensino. (Id., 1967, n. 106) 
Era recorrente essa comparação com outras pautas quando o deputado fazia frente à organização do esporte dentro do setor público.

A Assembleia passou a pressionar o Governo do Estado para formar grupo de estudos para a criação da lei que trataria do sistema estadual de desportos, de acordo com o artigo 127 da Constituição do Estado, que deveria ser de iniciativa do Poder Executivo (Id., 1967, n. 110). Em outubro, o deputado Roberto Rollemberg fez duras críticas ao Departamento de Educação Física e Esportes, acusando-o de abandonar o esporte paulista (Id., 1967, n. 196).

Em atendimento à indicação da Assembleia, o Governo do Estado de São Paulo instituiu, em outubro de 1967, comissão para proceder com estudo para a elaboração de anteprojeto de lei sobre o amparo ao desporto no estado de São Paulo (Id., 1967, n. 204). A Comissão formada por membros do governo tomou posse em 04 de novembro de 1967 (Id., 1967, n. 210).

Em novembro de 1967 a Câmara Municipal de São Paulo discutiu o projeto de Lei 116/67, de autoria do Poder Executivo, que visava conceder terreno da Prefeitura para o Centro das Indústrias pelo período de 40 anos, para a construção do parque Anhembi (Id., 1967, n. 214), sendo que os discursos foram favoráveis à concessão. Cabe aqui registrar que meses antes, em maio, o Setor Social da Indústria doou montante de $\mathrm{CR} \$ 12$ milhões para a Prefeitura aplicar no Conselho Municipal de Esportes, proceder com a compra de equipamentos para os clubes de várzea (Id., 1967, n. 82). Em novembro, o vereador Antônio Sampaio fez um pronunciamento destinado ao prefeito da capital para que este arrumasse outros terrenos para a construção de campos para atender os times de várzea, já que o espaço que esses times utilizavam seria cedido ao Centro das Indústrias.

Queríamos, nesta oportunidade, apelar ao Exmo. Sr. Prefeito da Capital, para que procure resolver um problema que vai surgir com a aprovação deste projeto, qual seja, a perda de perto de vinte campos de futebol na zona norte, onde cerca de oitenta clubes varzeanos, aos sábados e domingos, queimam suas energias num esporte sadio. De modo que não terão mais ele, dentro em breve, aquele magnífico local para a prática do seu futebol. (Id., 1967, n. 225) 
Apesar da relutância de alguns parlamentares, a Assembleia Legislativa de São Paulo recebeu requerimento para a criação da Comissão de Esportes, formada por cinco deputados, que visava,

apresentar relatório completo a respeito do problema da educação física e dos desportos entre nós, entrando em entendimento com as autoridades estaduais responsáveis do setor, com as diversas Federações responsáveis pelo esporte amador e com todos os outros setores que entender possam oferecer colaboração para uma visão completa do problema. (Id., 1967, n. 226)

O requerimento acima foi apresentado por um conjunto de quarenta deputados, e a justificativa, entre outras, era a falta de preparo do Brasil para as Olimpíadas que viriam,

As Olimpíadas de 1968 estão a poucos meses de sua realização e novamente o Brasil irá correr o risco das improvisações e das providências de afogadilho. $O$ esporte amador está relegado ao abandono. Não se tem notícias de campeonatos de futebol entre amadores, [...]. O atletismo amador não é solicitado nos colégios para disputas construtivas e o mesmo acontece com tantas outras modalidades de esporte. É preciso uma tomada de posição e um definição. (Ibidem)

Em seguida, os deputados passaram a discutir a importância do esporte amador e a apontar quais os possíveis problemas, inclusive culpando a Federação Paulista de Futebol por somente se ocupar dos clubes profissionais. A comissão de esportes foi definida em dezembro, formada pelos deputados Benedito Matarazzo, Salvados Julianetti, Geraldino dos Santos, Mario Telez Ruez Silva, Guilherme Gomes, Mendonça Falcão, Jacinto Figueira Jr., Egídio Semora, Alex Freira Neto. (Ibidem)

A elaboração do Plano Estadual de Esportes que estava em curso foi notícia de primeira página no Diário Oficial em janeiro de 1968,

De acordo com pensamento do governador Abreu Sodré, o deputado Orlando Zancaner ${ }^{6}$ já determinou providências no sentido de propagar a mentalidade esportiva na juventude, dentro das diretrizes básicas do Plano Estadual de Esportes, que visa ainda desenvolver o esporte amador em São Paulo. [...] serão realizadas, anualmente, competições de futebol, voleibol, natação, hipismo, boxe e atletismo em geral. Uma grande

\footnotetext{
${ }^{6}$ Secretário e Cultura, Esportes e Turismo do Estado de São Paulo.
} 
olimpíada universitária com a participação dos estudantes de todas as Faculdades do Estado inclui-se nesse programa (SÃO PAULO, 1968, n. 16)

A realização de competições foi fomentada durante todo o governo militar, restaurando campeonatos que ocorriam anteriormente e criando outros tantos. Em fevereiro de 1968, houve reunião dos delegados de esporte do Estado, e uma das definições foi justamente voltada a realização de competições, além da formação de atletas e arbitragem,

em pauta constam certames programados para o ano esportivo de 1968, destacando-se o Campeonato Colegial de Esportes, Troféu Bandeirantes, Jogos Regionais, Jogos Abertos do Interior e Jogos Infantis e Distintivo da Mocidade Paulista. Este último deverá ser incentivado, a fim de que os jovens voltem normalmente às suas atividades para a prática esportiva. [...] incrementar também as Turmas Volantes em várias modalidades esportivas e Cursos de Arbitragem, objetivando difundir ao máximo a prática do esporte amador. (Id., 1968, n. 22)

Em despacho, o governador publicou apoio ao Plano Estadual de Esportes apresentado por Orlando Zancaner, que era especialmente voltado aos campeonatos, que deveriam ocorrer sob a organização do DEFE (Id., 1968, n. 25). O projeto foi apresentado para apreciação dos deputados em dezembro de 1968 (Id., 1967, n. 239).

O governador propôs para discussão na Assembleia a unificação da Companhia Paulista Férrea e a Estrada Férrea Araraquarense. Na ocasião, indicou o Sr. Domingues Luz Faria, que estava ocupando o cargo de diretor do DEFE, para direção dessa Companhia unificada, o que causou controvérsia, pois segundo o deputado Santos Ferreira, ele não tinha capacitação para assumir o cargo. Em resposta, o deputado Roberto Gihara diz que a experiência dele vem da administração esportiva, o que nos dá um exemplo sobre a interposição de dirigentes de esportes em cargos públicos, e cita o governador,

Já tivemos um Governador de São Paulo, brilhante, que é presidente de clube de futebol e que, no seu pequeno período de governança, demonstrou brilhantemente o que pode fazer um homem do esporte, simples, humilde, que não tem diploma algum, mas que conseguiu o que $\mathrm{V}$. Exa. está pregando, a 
reunificação das centrais elétricas do Estado [...]. (Id., 1968, n. 65)

Em maio de 1968, tentou-se novamente discutir a taxação dos times profissionais em $5 \%$ de seus lucros para investimento no esporte amador, através de moção ${ }^{7}$ apresentada pelo deputado Avallone Junior. A justificativa novamente, deuse em torno da Olímpiada,

Novamente agora os atletas amadores terão de defender o nome do País nas Olimpíadas que serão promovidas no México, em setembro próximo, não se tendo notícia, até o momento, de que o Governo tenha feito qualquer coisa para ajudar concretamente aqueles esportistas, sacrificados em seu treinamento e com dificuldades de toda ordem para preparar-se devidamente para a referida competição. [...] enquanto não aprovada pelo Congresso Nacional a criação da Loteria Esportiva, seria a criação do imposto de $5 \%$ sobre as rendas das competições esportivas de caráter profissional [..] em benefício do esporte amador [...]. (SÃO PAULO, 1968, n. 96)

O deputado Avallone Junior insistiu na criação deste imposto por diversas ocasiões e sempre que lhe foi possível fez pronunciamentos nesse sentido na Assembleia Legislativa. (Id., 1968, n. 212)

Ainda em maio de 1968, ficou pronto o anteprojeto de lei que tratava sobre o Sistema Estadual de Esportes, que seria enviado para apreciação da Assembleia Legislativa. A Comissão enalteceu o governador, que segundo eles foi o primeiro que elevou o esporte ao nível de Secretaria. Entre as diretrizes estavam, "[...] a criação do Departamento e do Conselho de Esportes e Recreação; bem como de um Colégio Esportivo e do Fundo de Incentivo e Desenvolvimento do Esporte Amador." (Id., 1968, n. 101). O projeto foi aprovado em outubro de 1969 (Id., 1969, n. 197).

Além do Departamento de Educação Física e Esportes, o Governo do Estado tinha sob sua jurisdição a Escola de Educação Física do Estado, que deveria trabalhar junto ao DEFE, mas não era subordinada a ele. A falta de entrosamento entre os

\footnotetext{
${ }^{7}$ Moção 42/68.
} 
órgãos era motivo constante de críticas, e em agosto de 1968 instaurou-se na Assembleia uma Comissão Especial de Inquérito para verificar o funcionamento da Escola. O primeiro passo da Comissão seria visitar as instalações da Escola, que se localizava dentro do Ginásio do lbirapuera. Ao que parece, pelos pronunciamentos, a Escola estava em uma situação caótica, sendo que havia passado a dividir suas instalações com circos, nos quais havia jaulas com animais. Em fala, o deputado Ruy Codo expôs seu espanto com a situação, "Eu não acredito como, no fim do século XX, possamos manter uma escola de educação física nas mesmas instalações em que funcionam circos." (Id., 1968, n. 120)

Como tentativa de aumentar sua popularidade, o governador Abreu Sodré recebeu no Palácio dos Bandeirantes o deputado Mendonça Falcão, presidente da Federação Paulista de Futebol, juntamente com o presidente do Santos Futebol Clube e de Edson Arantes Nascimento, Pelé, para tratar da contratação do craque para ministrar aulas de Educação Física na TV Educativa do Estado. Essa ação sofreu duras críticas na Assembleia Legislativa, devido ao caráter de autopromoção da ação. Citamos o pronunciamento do deputado Orlando Jurca,

Esse anúncio do Sr. Abreu Sodré colou muito mal no Interior do Estado de São Paulo, porque acredito que Pelé, este fabuloso gênio do esporte nacional, é uma pessoa humilde e profundamente compenetrada da sua posição. É um moço que jamais deveria ser envolvido em política; é um moço realmente tão puro, que jamais deveria ter sua popularidade assim explorada por um Sr. Abreu Sodré, que quer se promover à custa daqueles que têm talento para ter popularidade e para serem grandes e para serem grandes perante a opinião pública. (Id., 1968, n. 148)

A ata da segunda reunião da CPI que investigava a situação da Escola de Educação Física do Estado foi publicada em novembro de 1968, e conta com o depoimento do major Padilha. Ele faz uma explanação longa da situação da Escola, da impossibilidade de culpabilizar o DEFE pela precariedade do departamento. Seu depoimento foi precedido de longo discurso no qual o major foi exageradamente enaltecido pelos deputados presentes na reunião,

Criaturas como V. As. Sr. Major Sylvio de Magalhães Padilha são criaturas iluminadas pelos reflexos do infinito. [...] Tê-lo hoje 
nesta Casa, creia, é um dia de honraria para a Assembleia Legislativa do Estado. Só lamento, Sr. Presidente, que outros deputados não venham saborear deste prazer do convívio com Sylvio de Magalhães Padilha. (Id., 1968, n. 221)

Parece-nos muito significativo o tratamento dispensado ao major Padilha em suas visitas às Casas Legislativas, tanto na Assembleia Legislativa, quanto na Câmara Municipal de São Paulo. O discurso anterior foi proferido pelo deputado Fauze Carlos, ocasião na qual o major fora à assembleia prestar esclarecimentos.

Em 1969 (ld., n. 162), Abreu Sodré determinou a obrigatoriedade da participação dos estabelecimentos estaduais de ensino de participarem do Campeonato Colegial de Esportes. Esse ato ia ao encontro das diretrizes do Plano Estadual de Esportes, que focava nas competições como meio de promover a integração do Estado. Também fez publicar, no início do ano, uma breve prestação de contas das atividades do DEFE no ano anterior, na qual falou do papel de São Paulo para a participação da delegação brasileira nas Olimpíadas do México (ld., 1969, n. 73).

A prefeitura de São Paulo, seguindo a tendência do estado de dar mais ênfase ao esporte, apresentou à Câmara Municipal projeto de lei que criava a Secretaria Municipal de Esportes (ld., 1969, n. 88). O projeto teve parecer favorável em junho, com algumas alterações, como por exemplo a extinção da Comissão Municipal de Esportes. (Id., 1969, n. 105).

Em junho, o vereador José Maria Marin fez pronunciamento na Câmara Municipal de São Paulo sobre a realização de campeonato de futebol mirim, organizado pela TV Tupi, denominado "Dente de Leite",

A Televisão Tupi, dentro do seu destino de pioneira, acaba de escrever mais uma efusiva página de engrandecimento das nossas coisas e da nossa gente. Trata-se de um campeonato de futebol disputado por meninos que, técnica e moralmente, superam muita gente grande. [...] O nosso entusiasmo por esse certame aumenta a cada partida que assistimos, [...] e o fazemos prazerosamente ao merecido elogio dos responsáveis pelo êxito do Dente-de-Leite. (Id., 1969, n. 151). 
Apesar de sabido o sucesso desse campeonato, que inclusive cunhou o nome de uma categoria usada ainda hoje, nos parece bastante sintomático que ele tenha se tornado evento oficial do Estado de São Paulo (Id., 1969, n. 215) já na sua primeira realização, e que isso tenha ocorrido logo após a fala do vereador José Maria Marin, posto que eventos oficiais demandam recursos públicos para a sua realização.

\subsubsection{Segundo Governo Laudo Natel (1971-1972) - Integração}

Definimos esse segundo governo de Laudo Natel como integração devido ao caráter das políticas públicas adotadas, que visavam à integração entre a capital e as demais cidades do estado, promovendo campeonatos estudantis, a padronização de construções voltadas à pratica de esportes e a padronização das ações públicas.

Ao tomar posse pela segunda vez como governador do Estado de São Paulo, o primeiro ato referente aos esportes tomado por Laudo Natel foi nomear Pedro Magalhães Padilha, filho do major Sylvio de Magalhães Padilha, para o cargo de secretário de Cultura, Esportes e Turismo (SÃO PAULO, 1971, n. 51). Por sua vez, Pedro Padilha renomeou seu pai, major Padilha, para assumir novamente a Diretoria do Departamento de Educação Física e Esportes, da qual ele estava afastado desde 1969 (Id., 1971, n. 54). Ao nomear o pai como Diretor do DEFE, Pedro Padilha justificou a escolha,

Homem feito às coisas do esporte e com larga folha de serviços já prestados nesse setor à Pátria e à coletividade. Como dirigente, tem chefiado inúmeras delegações do Brasil no Exterior; como administrador foi o criador da Diretoria de Esportes, hoje o DEFE, que com seu surgimento antecedeu a oficialização dos esportes no país. (ld., 1971, n. 57).

Durante sua cerimônia de posse, major Padilha explanou sobre sua intenção de trazer técnicos internacionais para promover a elevação técnica dos esportes no estado, além da criação de uma "mentalidade esportiva nas escolas" (Ibid.), e acrescentou que, "Desejamos ser uma unidade piloto para todo o País, pelo espírito pioneiro de que é capaz a gente deste Estado." (Ibid.)

Em abril, como no ano anterior, foi divulgada a prestação de contas do DEFE no Diário Oficial, onde foram definidas as suas funções, 
O DEFE tem como função primordial a divulgação, o incentivo e o controle da prática da educação física, recreação e esportes no Estado de São Paulo, sendo a sua estrutura base o Serviço de Esportes, Serviço de Educação Física, Serviço de Recreação, Conselho Regional de Desportos, Serviço de Administração de Próprios e Instalações Esportivas, Serviço de Centros de Educação Física, Serviços Auxiliares e Delegacias e Inspetorias Regionais. (Ibid.)

No texto de prestação de contas falou-se da criação do Sistema Estadual de Esportes, da realização dos campeonatos Colegial, Troféu Bandeirantes e Jogos Abertos do Interior, além do apoio de técnicos do DEFE na melhoria de infraestrutura em sedes de clubes amadores.

No início da nova gestão do DEFE, o Governo do Estado anunciou esforços conjuntos com a Capital para o trabalho no esporte, acordo firmado em encontro entre o major Padilha e Paulo Machado de Carvalho, secretário Municipal de Esportes de São Paulo, "O Estado e a Prefeitura da Capital já se entrosaram para o desenvolvimento do esporte amador, atendendo diretriz do governador Laudo Natel". (ld., 1971, n. 69). Em seguida, o Governo anunciou estudos para concessão de bolsas de estudo para estudantes esportistas do Estado.

O governador Laudo Natel determinou a desapropriação de um vasto terreno para a construção do Parque Recreativo Esportivo do Trabalhador, e recebeu agradecimentos formais do Sindicato dos Trabalhadores da Indústria, publicado no Diário Oficial (1971, n. 150). A construção foi anunciada no encerramento do III Campeonato Intersindical de Futebol (Id., 1971, n. 203).

Por ocasião da realização dos Jogos Pan-Americanos, o jornal O Estado de São Paulo publicou um editorial intitulado "Esporte e Política", no qual falava da performance de Cuba. Esse editorial foi debatido na Câmara Municipal de São Paulo, à sugestão do vereador Brasil Vita. Tanto o editorial quanto o debate promovido na Câmara procuravam justificar para a opinião pública o bom desempenho cubano na competição, já que, segundo a propaganda do governo brasileiro, a ilha vivia sob uma ditadura comunista. Dizia o editorial,

Os VI Jogos Pan-Americanos [...] foram a trágica encenação do totalitarismo castro-comunista em busca de popularidade por meio das atividades esportivas. Foi uma demonstração política 
aquilo a que se assistiu na bela cidade colombiana cujos resultados, no entanto, terminaram por chamar a atenção geral para o clima de insegurança, miséria e terror que se sobrepunha à boa atuação dos atletas cubanos ${ }^{8}$. (Id., 1971, n. 150).

O governo precisou dar uma resposta à população porque apesar de todas as acusações ao governo de Castro e aos regimes de esquerda de causarem miséria para a população, o desempenho cubano colocou essas alegações em cheque. A ilha ficou como segunda colocada na competição, contando com 105 medalhas. Brasil Vita fez gravíssimas acusações contra o governo cubano,

Apesar do trabalho de aliciamento das massas feito pelas esquerdas colombianas, o povo não demorou muito para compreender que por detrás do ímpeto dos atletas cubanos se escondia um sentimento irreprimível de medo. E, depois, havia as deserções, a violência das equipes com os fotógrafos da imprensa, os suicídios e os assassínios, a presença indisfarçável de agentes da polícia política entre os jogadores. [...]. A experiência tentada por Fidel Castro, no fim das contas, foi negativa, porque ele tinha necessidade imperiosa de obter bons resultados pelo menos no âmbito esportivo, seja para compensar o desastre da agricultura e o retrocesso da indústria, seja para melhorar a imagem de pesadelo que seu regime adquiriu. (Ibid.)

Como parte da diretriz de integração do Estado, o DEFE anunciou, durante reunião com as Comissões Centrais de Esporte e delegados de Educação Física e Esportes do Interior, em novembro de 1971 a intenção de construir Praças de Esportes espalhadas pelo interior do Estado,

a reunião serviu também para reavivar os contatos e a colaboração que deve existir sempre entre as prefeituras e Comissões Esportivas com o DEFE. Em 1969 e 1970 esta colaboração esteve relegada a segundo plano. (Id., 1971, n. 217).

O anúncio fazia questão de frisar a falta de comunicação entre o DEFE e as prefeituras durante o período em que o major Padilha esteve afastado do cargo de diretor do departamento.

\footnotetext{
${ }^{8}$ Editorial Esporte e Política, do Jornal Estado de São Paulo, in Diário Oficial do Estado de São Paulo.
} 
A primeira prestação de contas do DEFE feita durante a nova gestão do major Padilha procurou expor os esforços de integração com o interior do Estado,

Preocupou-se a Secretaria, neste setor em seu primeiro ano de nova administração, fundamentalmente, em intensificar o contato com o Interior do Estado e reaparelhar-se de forma a fazer chegar a todos os pontos os resultados de sua atuação. (ld., 1972, n. 63).

Era evidente o empenho do major Padilha de demonstrar que o DEFE não tinha um bom funcionamento sem a sua direção. Como parte das realizações do ano, o relatório citou os campeonatos estaduais realizados e a ajuda com transporte aos atletas que deles participaram.

Com a proximidade das Olímpiadas de 1972, Wadih Helu fez um pronunciamento na Assembleia Legislativa elogiando a atuação dos Padilha no esporte nacional,

Sr. Presidente, srs. Deputados, prepara-se o Brasil para participar de mais uma Olimpíada Mundial. [...] Trabalhando como técnicos e dirigentes para que essa equipe seja das melhores, há muitos patrícios nossos que nos merecem o mais sincero respeito. Dentre eles destaco essa figura que é o major Sylvio de Magalhães Padilha, o qual, ao retornar à direção do Departamento Estadual de Educação Física e Esportes, mantém vivo aquele mesmo entusiasmo de tempos passados, que lhe granjeou a admiração de nossa gente. Trabalhando hoje ao lado de seu filho, esse magnífico criador e realizador que é Pedro de Magalhães Padilha, secretário Estadual de Cultura, Esportes e Turismo, o major Sylvio de Magalhães Padilha prossegue, pois, na execução de um programa de realizações que dá a São Paulo um lugar de destaque não só no Brasil, mas no Continente, como um Estado em que as atividades esportivas vêm completar, no campo da formação moral dos moços, a contribuição que os poderes públicos devem oferecer aos futuros cidadãos. (Id., 1972, n. 103).

O esporte no Estado de São Paulo era muito personificado na figura no major Padilha, e este tratava o Departamento de Educação Física e Esporte de maneira muito peculiar, cremos que podemos dizer que ele agia e era tratado quase como patrono do esporte no Estado. 
Em junho de 1972, o governador Laudo Natel e o secretário Pedro Padilha encaminharam a requisição de 22 prefeituras do interior do Estado para a construção de centros de esporte, como parte do programa Pro-Esporte, que começara a ser formulado naquele ano (Id., 1972, n. 114). O programa foi anunciado em agosto, durante inspeção de obras nas cidades de Leme, Araras e Conchal,

O governador Laudo Natel anunciou que dentro de alguns dias serão formuladas as diretrizes e metas do PRO-ESPORTE, um programa que abrangerá todos os municípios e que visa dotálos de instalações esportivas adequadas para atender às necessidades das populações jovens, "que devem ter nos esportes o complemento para a educação que recebem nos bancos escolares e no lar". (ld., 1972, n. 166)

Havia preocupação com integração também no âmbito nacional, e discutiu-se na Assembleia Legislativa o papel do esporte para essa questão, através das transmissões de rádio e TV, o que nos mostra a importância do esporte para o governo militar,

Nobre deputado, nesta hora em que assistimos a essa integração que o esporte realiza, são o rádio e a televisão, mas principalmente o rádio, que transmite em rede com tanta facilidade, que torna possível $V$. Exa. vê nas transmissões esportivas. São vozes vindas de toda a parte que interrompem o locutor para dar as últimas notícias: 'Confira a loteria esportiva'. [...] E no sábados e domingos, com essas transmissões via Embratel, o Brasil todo entra na casa da gente. (Id., 1972, n. 201)

Em novembro de 1972 foi oficialmente lançado o programa Pro-Esporte, com suas diretrizes e metas definidas, propondo o orçamento de 50 milhões de cruzeiros para a construção de equipamentos esportivos em 400 municípios do Estado de São Paulo,

O Governo do Estado inicia, hoje, a implantação de uma infraestrutura que tem por objetivo fundamental fazer com que as atividades esportivas alcancem, entre nós, o crescimento que atingimos em tantos outros setores. (ld., 1972, n. 217)

O programa iniciaria suas obras no ano seguinte, sob jurisdição da Secretaria de Cultura, Esportes e Turismo e do DEFE. 


\title{
3.4 Equipamentos
}

Os equipamentos públicos esportivos tiveram ações voltadas para a potencialização do seu uso no esporte, além de servirem como propaganda de ações do governo do Estado. Falaremos sobre o Estádio do Pacaembu e sobre Interlagos, além o lbirapuera, que será tratado em capítulo à parte, devido ao porte das obras envolvidas, além do seu papel de metáfora da realidade política da época.

\subsubsection{Estádio do Pacaembu}

O Pacaembu foi objeto de disputas de interesses durante o período proposto, e apesar de ser um equipamento municipal, sofreu interferência também no âmbito estadual. Foi palco de manifestações políticas, como o ocorrido em 17 de maio de 1964, quando 70 mil evangélicos usaram o estádio para, entre outras coisas, manifestar apoio ao novo governo militar. Essa ação foi publicizada por pronunciamento feito na Câmara Municipal de São Paulo, pelo vereador Galdino dos Santos,

\begin{abstract}
A Igreja Evangélica Pentecostal "O Brasil para Cristo" promoveu monumental concentração religiosa domingo passado, dia 17, no Estádio Municipal do Pacaembu. Foi apoteótica a reunião que contou com uma multidão calculada em mais de 70 mil pessoas, tendo em vista a superlotação daquela praça de esportes. Compareceram ao conclave prestigiando-a, o Exmo. Sr. Secretário da Justiça Prof. Miguel Reale, o qual foi homenageado por sua atuação justa e imparcial no caso da discriminação do ensino religioso nas escolas públicas, permitindo que alunos de todos os credos recebam instrução religiosa de suas respectivas igrejas e credos; e ainda 0 Deputado Antônio Silvio da Cunha Bueno por sua atuação à frente de diversas campanhas anticomunistas e efetiva participação no movimento revolucionário do mês passado. (SÃO PAULO, 1964, n. 96)
\end{abstract}

Durante o governo do prefeito Faria Lima na cidade de São Paulo se estabeleceu uma disputa entre a Câmara Municipal de São Paulo e a Federação Paulista de Futebol. O presidente da Federação solicitou ao prefeito a permissão para 
aumentar os valores dos ingressos para os jogos no estádio. Vale ressaltar que no ano anterior a Prefeitura havia onerado os times amadores que usavam o estádio, triplicando o valor da cobrança de aluguel do equipamento (S. PAULO, 1964, n. 188). Em pronunciamento na Câmara Municipal, o vereador Francisco de Moraes se posiciona contrário ao aumento, e avisa da sua pretensão de apresentar projeto de lei que fixa um teto para a cobrança nos ingressos,

Leio nos jornais que o presidente da Federação Paulista de Futebol foi pleitear do Sr. Prefeito aumento para as entradas no Estádio do Pacaembu [...]. Isso representa uma majoração de $100 \%$ [...]. Apresentarei projeto de lei fixando um teto para 0 preço dos ingressos nos estádios e ginásios do Município. Não é possível que se receba sem protestos e providências enérgicas uma elevação tão brutal nos preços de ingressos para as partidas de futebol. (Id., 1965, n. 102)

Seguindo com o pronunciamento, o vereador tece duras críticas à Federação,

[...] As rendas dos jogos de futebol não são empregadas no próprio esporte, mas na aquisição de jogadores a preços inflacionários nos mercados desportivos. E o que é mais grave: A Federação pretende elevar os preços dos ingressos apenas para contornar a evasão de rendas provocada pelas entradas de favor, distribuídas aos milhares nos anos eleitorais. E não é só a Federação prejudicada pela generosidade de seu Presidente, mas também a Prefeitura, que perde $12 \mathrm{Cr} \$$ em cada ingresso gracioso. (lbid.)

Em novo pronunciamento, em 02 de julho, o vereador faz sugestão para que a Federação construa seu próprio estádio, maior que o Pacaembu, para que assim cobre menos e ganhe mais através de uma renda global avolumada, lembrando a ocasião em que foi secretário de Finanças de São Paulo, e que teve sua tentativa de cobrar o Imposto de Diversões Públicas, que era instituído por lei, vedada pela Federação, juntamente com a Câmara, que passou um projeto isentando o futebol deste imposto sob a justificativa de que não poderia se dificultar o acesso ao "grande esporte diversão das massas populares". (ld., 1965, n. 120)

Dois anos depois, a mesma discussão voltou a ser pauta da Câmara Municipal, devido a nova pretensão da Federação Paulista em aumentar o valor dos ingressos. O vereador Monteiro Carvalho faz fala contrária ao aumento dos ingressos no plenário 
da Câmara, e defende que a Federação e a CBD construam estádios próprios para não usarem comercialmente imóvel público - como definiu o Pacaembu. Em sua fala, ele cita pressão de deputados estaduais, e fala da atuação do Conselho Municipal de Esportes, que vedou a pretensão da Federação,

Felizmente, desta vez, no Conselho Municipal de Esportes, está o nosso colega Tabajara Vidigal Leitão, e S. Exa., que é radialista e comentarista de futebol, entendeu, mui acertadamente, de defender o povo, e contrariou as pretensões da CBD e da Federação Paulista de Futebol. Graças a sua atitude foram mantidos os preços para as "acomodações populares" ou gerais. Posso imaginar como deve ter ficado contrariado o Deputado Mendonça Falcão ${ }^{9}$ de ver que o nobre vereador Tabajara Vidigal Leitão não esqueceu que é representante do povo. (Id., 1967, n. 198)

Ainda em 1967, a Câmara Municipal colocou em pauta de discussão o que se convencionou chamar de "Ocorrência Coronel Fontenelle", que se tratava da contratação do Grupo Fontenelle - FONTEC, para

"assumir a responsabilidade por barricadas e propiciar condições de desorganização completa na vida comercial, industrial e até desportiva "segundo declarações do Presidente da Federação Paulista de Futebol, Deputado João Mendonça Falcão"10" (ld., 1967, n. 56)

Segundo o vereador Benedicto Rocha, a contratação do grupo FONTEC provinha de um acordo feito na sede da ex-UDN na Guanabara, onde nasceu "certa organização" de competência extraordinária, apadrinhada por Carlos Lacerda, que visava entregar ao coronel Fontenelle a reestruturação dos serviços de transporte e até de polícia, e que seria indicada a todos os governadores da UDN (lbid.). No que diz respeito ao Pacaembu,

[...] o acontecimento Fontenelle apresenta-se ainda com maior gravidade porque a nossa economia está sendo arranhada de forma a provocar reações até no esporte. Deputado Mendonça Falcão apontou como principal fator de queda de arrecadação no Pacaembu a falta de transporte, porque não é o rico que vai ver o futebol [...], se ele não tem condução para vir à cidade tampouco a tem da cidade para o Pacaembu para assistir 0

\footnotetext{
${ }_{9}^{9}$ Presidente a época da Federação Paulista de Futebol.

${ }^{10}$ Fala do vereador Benedicto Rocha. Diário Oficial do Estado de São Paulo.
} 
futebol. Então até o esporte está sendo atingido por essa antipática Operação Bandeirante que só mesmo o governo udenista de Abreu Sodré poderia contratar. (Ibid.)

É importante frisar que Mendonça Falcão teve seu mandato de deputado cassado em 1968, após decretação do Al-5, acusado de tráfico de influência.

No fim de 1968, a Câmara Municipal deu entrada em dois requerimentos de ampliação do Pacaembu, alegando que o espaço não mais atendia às necessidades da cidade. Ambos os requerimentos foram apresentados pelo vereador Sender Fichman, e propunham o fechamento da concha acústica para a ampliação de 50\% da capacidade do estádio (Id., 1967, n. 176), além da construção de novo estádio municipal (Id., 1967, n. 246). Um novo pedido foi feito em março de 1968, pelo vereador Tabajara Vidigal, para que se seguisse com a ampliação do Pacaembu, contudo ele deixa claro que

Move-se na verdade uma guerra surda contra o velho estádio que indiscutivelmente ainda presta bons serviços até hoje. [...] até agora, nenhuma das grandes multidões que tenha comparecido aos grandes espetáculos, não tivesse cabido dentro do Estádio do Pacaembu. (Id., 1968, n. 58)

Indo na mesma direção, foi solicitado pelo deputado Osvaldo Massei que o prefeito de São Paulo seguisse com a construção de um novo e maior estádio Municipal (Id., 1968, n. 112). Ainda em 1968, o vereador João Lemos relatou no plenário da Câmara o "estado de abandono" em que se encontrava o Pacaembu onde, segundo ele, além das péssimas condições do estádio, ocorriam situações a serem averiguadas, como o caso da piscina, que apesar de uma empresa privada ter ganho a concorrência para a sua manutenção, eram os próprios funcionários do estádio que cumpriam (mal) esta função. (Id., 1968, n. 189)

Em maio de 1969, o vereador José Maria Marin faz um pronunciamento solicitando ao prefeito Paulo Maluf que trate do autódromo com o mesmo "carinho" que tratou o Pacaembu (Id., 1969, n. 86). No mês de setembro a Câmara debateu a questão da reforma de maneira mais aprofundada, apresentando os custos do projeto. O vereador Freitas Nobre foi o porta-voz da posição contrária ao projeto, visto que demandaria um alto valor que seria tirado da rubrica de pagamento de "pessoal civil", 
o que, segundo ele, comprometeria as questões administrativas da prefeitura, além de haver na cidade obras de maior urgência (Id., 1969, n. 174). Fazendo as vezes de defesa do projeto, o vereador Jihei Noda fala do caráter poliesportivo do Pacaembu, que apesar de pouco conhecido oferece condições para prática de diversos esportes, não somente futebol, e da importância da sua reforma para o esporte nacional,

O Brasil, apear dos seus 90.000 .000 de habitantes, apesar das variadas raças de que é constituído, não conseguiu até hoje resultados positivos nas Olimpíadas. Para que tal ocorra é preciso que permitamos a reforma do Pacaembu, a fim de que nossos filhos amanhã tragam para o Brasil galardões que representem o orgulho da nacionalidade [...] que se o adapte neste momento para, depois, entregá-lo ao atletismo, ao futebol amador, porque o Estádio Municipal do Pacaembu deve servir para preparar a nossa mocidade, para preparar os nossos Pelés, e assim nós teremos contribuído para a grandeza da nossa pátria. (lbid.)

Mesmo com a discussão sobre a procedência do projeto, o estádio já estava fechado há quase um ano para reformas. Em 12 de setembro, José Maria Marin faz uma fala na Câmara sobre a reabertura do Pacaembu, após como ele disse "fechado inexplicavelmente há mais de um ano", e "devolvido ao povo depois de passar por reformas de há muito reclamadas" (Id., 1969, n. 182), ocasião em que teceu elogios ao prefeito Paulo Maluf.

A fala de Marin sobre o "inexplicavelmente fechado" Pacaembu repercutiu na Câmara, e no dia 05 de novembro o vereador Vicente de Almeida fez um longo pronunciamento denunciando condutas reprováveis na condução das reformas no Pacaembu, incluindo o uso político da reinauguração. Em sua fala, o vereador dá um panorama das matérias que saíram parabenizando o "prefeito jovem e dinâmico" pela reforma do estádio, contudo, segundo o vereador, todas as obras foram contratadas na gestão anterior, seguiram paradas por quase 200 dias, e depois foram apressadas para se proceder com a reinauguração. Ele também fala da matéria que saiu no jornal O Estado de S. Paulo, com o título "A pressa causou tudo", onde o engenheiro chefe Alfredo Gailland diz que avisou que precisava de mais tempo, e que o alagamento do gramado, ocorrido logo após a inauguração, e que demandou a suspensão de jogos, não teria acontecido se tivessem respeitado o prazo da obra (Id., 1969, n. 212). Em defesa da inauguração, o vereador Caio Pompeo de Toledo ressaltou que a 
inauguração não acarretaria danos ao gramado caso este não fosse usado de modo excessivo, conforme a mesma entrevista, e fez a defesa da Federação Paulista de Futebol e da Prefeitura durante uma longa discussão no plenário.

\subsubsection{Autódromo de Interlagos}

A partir de 1966 o Autódromo de Interlagos passou por reformas, realizadas por pressões externas à prefeitura, inclusive do jornal Folha de São Paulo, conforme fala do vereador Benedicto Rocha,

O Autódromo de Interlagos [...], vai passar por pequenas, urgentes e inadiáveis reformas. Assim decidiu o Prefeito Faria Lima, atendendo a uma solicitação do prestigioso jornal "Folha de S. Paulo", um dos grandes incentivadores do desporto automobilístico entre nós, a fim de permitir a realização das provas da Semana da Velocidade. Congratulo-me com o Senhor Prefeito, com o jornal de Otávio Frias de Oliveira, e com os associados do Automóvel Clube e da Associação Paulista dos Volantes de Competição, pela providência. (SÃO PAULO, 1966, n. 159).

Uma nova reforma foi feita em 1968 em Interlagos, e esta previa a construção do "Parque Municipal de Interlagos", o que foi alvo de diversas críticas, como a do vereador Pereira Barreto, que defendia que o espaço devia ser direcionado especificamente para a prática do automobilismo,

Ficamos seriamente preocupados e temendo pelo futuro do automobilismo em nosso Estado quando o Prefeito Faria Lima, com grande alarde, anunciava o seu projeto chamado "Parque Municipal de Interlagos", como sua contribuição para a solução do tão encantado problema do nosso autódromo, e como primeira medida interditava-o à prática do automobilismo. Esse fato pareceu um enterro simbólico desse esporte. (Id., 1966, n. 105).

Segundo Pereira Barreto, o fechamento do autódromo para as corridas durante o pronunciamento o autódromo estava fechado há sete meses -, não era justificado, visto que as obras não eram na pista principal. O pronunciamento tinha tom de denúncia, visto que ele acusa a prefeitura de fazer as obras não respeitando 
os estudos e planejamentos feitos anteriormente, e prevendo a inauguração antes do fim do mandato de Faria Lima, que capitalizaria politicamente a entrega da obra,

Enquanto piloto, mecânicos, [...] esperam pacientemente pela sua reabertura, certos de que, pelo menos se apresentará com uma pista remodelada e com obras que realmente justifiquem 0 seu fechamento, nada acontece nesse sentido. O que vemos hoje em Interlagos é apenas uma criminosa e injustificável derrubada de eucaliptos [...], um oneroso movimento de terras [...], cuja localização é o atestado da ignorância a tudo que já foi estudado e planejado [...]. E guardem bem, nobres colegas, quando de sua reabertura, que será logicamente antes da saída do Sr. Faria Lima, naturalmente farão um "Grande Prêmio", que levará o nome de algum desses "salvadores" de Interlagos. (lbidem.)

É importante apontar que Pereira Barreto apresentou projeto de lei na Câmara ${ }^{11}$ que autorizava a Prefeitura de São Paulo a conceder, via concorrência pública, o autódromo à iniciativa privada, e que o projeto foi aprovado em primeira discussão em 02 de dezembro de 1967. Menos de um ano após o pronunciamento acima, o projeto de privatização entra em discussão no plenário da Câmara e o vereador Vicente de Almeida pede o adiamento da discussão, por 50 sessões, para remeter o projeto para manifestação do Poder Executivo, visto que o texto do PL que previa a construção do autódromo era anterior às reformas feitas pela Prefeitura. (SÃO PAULO, 1969, n. 52).

\subsection{O (conceito de) Esporte nos governos do Estado}

Conforme analisamos a documentação acerca das ações do Estado no esporte, notamos as mudanças de percepção sobre o que o esporte poderia proporcionar de benefícios na relação governo x sociedade.

Mais que marcar o que é esporte, acreditamos ser necessário entender o porquê do esporte para o governo. No primeiro período levantado, governo de estruturação de Adhemar de Barros, os esforços públicos estavam voltados para a

\footnotetext{
${ }^{11}$ Projeto de Lei 54/67.
} 
estruturação de equipamento que proporcionasse condições de prática esportiva aos estudantes e a construção de espaços públicos que permitissem à população usufruir do esporte enquanto lazer, em seu tempo livre.

Reconhecemos aqui um esforço de controle do tempo livre da população por meio de atividades carregadas de um caráter pedagógico específico que, acreditavase, culminava em controle social. Quando a vereadora Dulce Braga diz sobre o diretor do DEFE, Sylvio Padilha, "Não lhe bastou ter sido um atleta multiforme que se destacou afinal no esporte-base. [...] homem perfeitamente realizado. Aprendeu a obedecer para depois comandar" (op. cit.), nos fica bastante claro qual papel o governo queria que o esporte cumprisse. Sendo assim, para o governo, o esporte cumpriria um papel civilizador e de controle da população muito mais eficaz que coerções diretas, conforme explica Norbert Elias (1997, p. 44), "no decorrer de um processo civilizador, o mecanismo de autocoação torna-se mais forte que as coações externas".

Segundo DaMatta (2006), em uma partida de futebol - e entendemos que isso se aplique a qualquer modalidade-, jogadores, árbitros e demais envolvidos "estão voluntária e prazerosamente submetidos, num grau jamais atingido na 'vida real', às 'regras do jogo'”, e esse exercício de subordinação pode ser internalizado e projetado para os demais campos da vida, proporcionando um caráter educativo e civilizatório para o esporte que diminua insurgências sociais. Acreditamos que essa disposição do esporte foi fator de interesse do governo, tendo em vista seu caráter ditatorial, logo, era interessante investir em algo que "civiliza e ordena" (Idem).

Durante o governo Laudo Natel, além da questão civilizatória, o esporte foi abordado pelas ações do governo como ferramenta de entretenimento da população. Segundo do deputado Jacob Carolo, "A recreação entra na vida do homem com a mesma importância da alimentação e da habitação", e era papel do governo proporcionar isso a seus cidadãos". (ld.)

Para DaMatta, "experiência com a vitória, com a excelência, com o esforço e o sacrifício coletivos, com entregar-se de corpo e alma a uma camisa-causa, permite voltar ao trabalho com novas disposições" (LUDOPÉDIO, 2010), o que vai ao encontro da necessidade de um estado que baseou sua política econômica no acúmulo de capital humano, conforme tratamos no primeiro capítulo. 
Durante o segundo governo de Laudo Natel, o esporte continuou sendo tratado dentro desses aspectos de agente civilizador, de controle e "distração" da população, porém com mais amplitude das ações.

No período anterior ao segundo governo de Natel, o governador Abreu Sodré tratou de cuidar do papel do estado nas regras no jogo,

A emergência do desporto como uma forma de confronto físico de tipo relativamente não violento encontrava-se no essencial, relacionada com um raro desenvolvimento da sociedade considerada sob a perspectiva global: os ciclos de violência abrandaram e os conflitos de interesse e de confiança eram resolvidos de um modo que permitia aos dois principais contendores pelo poder governamental solucionarem as suas diferenças por intermédio de processos inteiramente não violentos, e segundo regras concertadas que ambas as partes respeitavam (ELIAS, 1992, p. 49).

Sendo o responsável pela normatização das regras (formais) de convivência em sociedade, nesse período o Estado dispensou maiores esforços para normatizar as políticas públicas de esporte, com a criação de comissões e a ampla discussão do assunto das casas legislativas, numa clara preocupação de apropriação da pauta esportiva. 


\section{Capítulo IV}

\subsection{Da criação do Parque do lbirapuera - Breve Histórico}

O Ibirapuera nasceu a partir da demanda da cidade por áreas de lazer e passeios públicos. O terreno, conhecido como Várzea de Santo Amaro, foi adquirido pela prefeitura de São Paulo em 1927, por iniciativa do então prefeito José Pires de Rio.

Nas primeiras décadas do XIX, a cidade de São Paulo passou por um acentuado crescimento demográfico ${ }^{12}$, que aumentou a pressão da população sobre a gestão pública para o provimento de mais áreas verdes e de lazer, visto que os espaços disponíveis já não supriam a demanda da cidade. Vale ressaltar que muitas das áreas verdes existentes até a década de 30 eram de propriedade privada, como o Bosque da Saúde, o Jardim Aclimação e o Parque Antártica, e que eram usadas informalmente para lazer e formação de clubes esportivos, sobretudo os de futebol. (Ibid.)

Sendo assim, o Ibirapuera, desde a sua idealização, sempre foi usado como artificio político pela gestão municipal; acreditamos ser muito menos oneroso para a prefeitura se comprometer com uma área grande do que gerir diversas áreas menores na cidade, além de considerarmos que a visibilidade do anúncio da aquisição do terreno de mais de 2.000 .000 metros quadrados poderia trazer diversos benefícios para a gestão (CURI, 2018).

Quando de sua inauguração, mais de 20 anos após a aquisição do terreno, em 1954, o parque do lbirapuera já não comportava a demanda da cidade, que nessa década passava dos 6 milhões de habitantes.

Segundo Jorge Americano (1963), o parque foi inaugurado de maneira pouco convidativa para a população pobre da cidade,

É estranho como São Paulo não tem parques no perímetro urbano. Os únicos são o Parque D. Pedro II, que separa o Brás do Centro, o Ibirapuera e o parque fronteiro ao museu do Ipiranga. Mas nenhum dele é lugar de descanso. Os bancos são

\footnotetext{
${ }^{12}$ São Paulo passou de 240.000 habitantes, na virada do século, para mais de um milhão de habitantes em 1934. BARTALINI, Vladimir. Parques públicos municipais de São Paulo. Tese (Doutorado).
} 
poucos, muito distantes uns dos outros e não há o recurso de sentar ou deitar na grama, porque é proibido. A população Pobre não tem onde repousar ao ar livre nos domingos. (AMERICANO, 1963).

O parque, a priori, foi inaugurado como um espaço de contemplação da natureza, com poucos bancos e com a proibição da população sentar-se ou se deitar na grama, contrastando com a proposta de lazer público do qual foi promessa em sua aquisição. Somado a isto o acesso era bastante complicado para a maioria da população paulistana. Segundo Curi (2018), o Ibirapuera reverberava as duas contradições de grandes parques contemporâneos a sua construção, o Central Park de Nova York, que também proibia a permanência em repouso em suas dependências, e o francês Buttes Chaumont, que por ter sido construído essencialmente para suprir a necessidade dos operários moradores do 19ème, em um terreno que antes abrigava um lixão, promovia pouca ou nenhuma interação entre classes sociais, devido a sua localização.

A exemplo dos dois, apesar de aberto à população e esta fazer uso do espaço, o Ibirapuera tornou-se um espaço muito pouco democrático (CURI, 2018, p. 124).

Durante as comemorações do IV Centenário da cidade, o parque do lbirapuera passou por num replanejamento e reestruturação, sendo o responsável o arquiteto Oscar Niemeyer, convidado por Ciccillo Matarazzo, presidente da Comissão do IV Centenário, após a desistência de uma primeira equipe ligada aos Departamentos de Urbanismo e de Arquitetura da Prefeitura Municipal, que abandonou o projeto, sobretudo, por falta de verba (ANDRADE, 2004).

A primeira equipe responsável pela remodelação do parque estava ligada a Comissão dos festejos do IV Centenário, e foi dividida em três categorias: "Diversões populares, culturais e exposições"; "Cultura Universitária" e "Esporte", segundo relatório entregue ao Governador do Estado, Lucas Nogueira Garcez (DPH,1934). Dentro da temática proposta neste trabalho, nos interessa sobretudo o planejamento da equipe que cuidava do grupo "esporte".

Os esforços desta equipe foram para que as modalidades mais populares focassem nos pontos com acesso mais facilitado do parque, e considerou integrar ao trabalho dos festejos o uso dos equipamentos existentes na cidade, como o Clube 
Hípica de Santo Amaro, as represas Guarapiranga e Billings e o Pacaembu. Vale ressaltar que esta equipe idealizou a construção do Ginásio, como parte do projeto do IV Centenário da cidade.

O primeiro projeto apresentado pela equipe de Niemeyer planejava a construção de diversos edifícios, mudando de forma substancial a primeira ideia do que seria o parque na sua aquisição. Assinado por Joaquim Cardoso, a introdução do projeto dizia que era preciso seguir a

natural capacidade em adaptar elementos construtivos de descobertas recentes [...] os edifícios deste conjunto arquitetônico evocam [...] o complexo das atividades técnicas modernas, representando simultaneamente a unidade e a multiplicidade do trabalho humano; evocam os resultados objetivos deste trabalho, instalam a consciência de uma época de operosas realizações e consolidam, na matéria inerte, toda uma ordem de ideias puras e exatas (DPH, 1934).

Desse projeto, após alguma apuração junto a Prefeitura de São Paulo, resultou a construção do Pavilhão de Exposição (OCA), o prédio que abriga a Fundação Bienal, os pavilhões das Nações, José da Nobrega, da Agricultura (Detran) e dos Estados (Prodam). O Parque foi inaugurado em 1954, prometendo ser um espaço de integração de arte, lazer e esportes, contudo, vemos que com o tempo o espaço verde e a programação das construções foram cedendo espaço para abrigar instituições do estatais, o que culminou no apelido de "Brasília Paulistana"13 para o complexo (parque e entorno).

Após sua inauguração, o poder público resolveu instituir a Fundação Ibirapuera", que seria responsável pela gestão do parque e do complexo viário em seu entorno. A lei de fundação foi publicada em 1957, assinado pelo então prefeito de São Paulo, Wladimir de Toledo Pizza. A Lei 5.123/57, "autorizava promover, juntamente com o Governo de São Paulo, a instituição da Fundação Ibirapuera"14.

O texto da lei previa como atividades da Fundação fomentar atividades "culturais, artísticas e cientificas; manter rodízio de exposições de caráter industrial,

\footnotetext{
${ }_{13}$ Termo usado pelo jornal $A$ Gazeta em abril de 1961.

${ }^{14}$ Lei no 5.123 , de 20 de março de 1957.
} 
comercial e agrícola, nacionais e estrangeiros. Manter um parque ornamental, educativo e recreativo; além de estimular o turismo científico, artístico e cultural (Id.). Nos chama atenção que em nenhum momento o fomento as práticas esportivas são citadas como prerrogativa da Fundação Ibirapuera, apesar das condições físicas disponíveis e dos relatórios anteriores.

\subsection{Ciccillo e o quintal de casa}

Desde a aquisição das terras do parque, a concepção do que seria o Parque, seus usos e ocupantes mudou diversas vezes. Só projetos oficiais, contamos com mais de dez, como nos mostra Andrade (2004).

No Brasil, as coisas pública e particular sempre foram confundidas, mais ou menos escancaradamente, e a divisão do que é público e privado sempre contou com matizes bastantes sutis. Voltando-nos para as comemoração do IV Centenário da Cidade, muito próximo à inauguração do Parque, um desentendimento de ordem pública, mas de ares pessoais, culminou na demissão de Ciccillo Matarazzo do comando da Comissão de Organização dos eventos, pelo o prefeito Jânio Quadros. A demissão foi feita publicamente, motivada pelo fracasso dos cortejos do carnaval daquele ano, 1954, que também eram de responsabilidade da Comissão (CURI, 2018).

A demissão de Ciccillo não o afastou do planejamento da remodelação do Parque, nem tão pouco da ordenação burocrática que esse planejamento demandava, o que para nós ressalta essa particularização do público, visto que o prefeito da cidade, e aqui não estamos fazendo juízo de valor quanto à pertinência da demissão, o havia deposto do cargo.

Ciccillo de fato deixou a presidência da Comissão do IV Centenário às vésperas da inauguração do parque. Embora fosse substituído pelo poeta Guilherme de Almeida, manteve-se em posição central e diretamente relacionado às comissões do parque que se formaram nos anos seguintes - bem na mira da politicagem e da burocracia. Sua figura, sempre relacionada ao parque, levanta uma questão [...]: a apropriação do público pelo privado... (Idem.) 
Essa questão da apropriação nos parece muito forte em toda a história do parque. A demissão de Ciccillo causou uma mobilização entre artistas, intelectuais e industriais, que não concordavam com seu afastamento do projeto.

Uma cerimônia de apoio foi realizada com a presença do governador, Nogueira Garce $z^{15}$, e diversos nomes de destaque, nos dão a impressão de que o parque era tratado quase como propriedade de Ciccillo, ou como presente pessoal dele para a cidade. "Essas obras do IV Centenário de devem a Ciccillo, e a mais ninguém"16, e, ao ganhar uma tela de De Chirico, Ciccillo publicamente proferiu a seguinte frase, ao fazer a doação da pintura para o MAM: "Um quadro como esse que me deram era muito bom pra guardar na minha casa. Por isso, já fica aqui mesmo, no Museu"17. Para nós, a fala de Ciccillo, que se referia ao parque como sua casa, e a mobilização de nomes ligados à elite cultural que protestaram contra sua demissão, agindo quase como uma sociedade de classe defendendo seu clube de fim de semana, evidencia para quem destinava-se o uso daqueles espaços.

\subsection{A luta por espaços, ou a falta de espírito esportivo}

Jânio Quadros se elegeu prefeito de São Paulo, em 1953, com 65,8\% dos votos. Pouco entusiasmado com os gastos do IV Centenário, e após desentendimento com Ciccillo Matarazzo, não compareceu à inauguração do parque (CHAIA; SADEK, 1991).

Desde a compra do terreno pelo prefeito Pires do Rio, em 1926, o Ibirapuera foi repensado diversas vezes, sempre ao sabor dos anseios dos novos governantes.

A longa trajetória percorrida - com dez projetos sucessivos, elaborados entre 1929 e 1953 - demonstra as expectativas, as dificuldades e a tenacidade da administração pública municipal

\footnotetext{
${ }^{15}$ A Francisco Matarazzo Sobrinho, expressão do gênio de iniciativa e do trabalho abnegado dos paulistas, sempre animado do mais alto espírito público e orientado num sentido profundamente humano, A gratidão de São Paulo pelo que idealizou para comemorar o IV Centenário de sua Fundação. Fala do Governador Lucas Nogueira Garcez. Ciccillo 1954 - citado em Curi 2018.

${ }^{16}$ Fala de Paulo Duarte - Ciccillo 1954 - citado em Curi 2018.

${ }^{17}$ Ciccillo 1954 - citado em Curi 2018.
} 
e do povo paulistano em implementar a criação de um parque urbano na cidade de São Paulo (ANDRADE, 1934).

Para o presente trabalho, nos interessa analisar o quanto a prática esportiva, ou a destinação de espaços para tal, esteve presente dentro do planejamento do parque e dos projetos que antecederam a construção do complexo esportivo.

O primeiro projeto, datado de 1929, assinado por Reynaldo Dierberger previa espaços como a Hípica e o estádio de ginástica, espaços para a prática de caminhadas, natação e "jogos olímpicos" (PMSP, 2006). Posterior a este, e tendo Dierberger como base, o parque recebeu um novo projeto, a partir do Plano de Avenidas de Prestes Maia, e que "Pensa também na execução de um lago, em local propício, como se refere também, e pela primeira vez, na determinação de um espaço exclusivo para esportes e recreação." (OLIVEIRA, 2003)

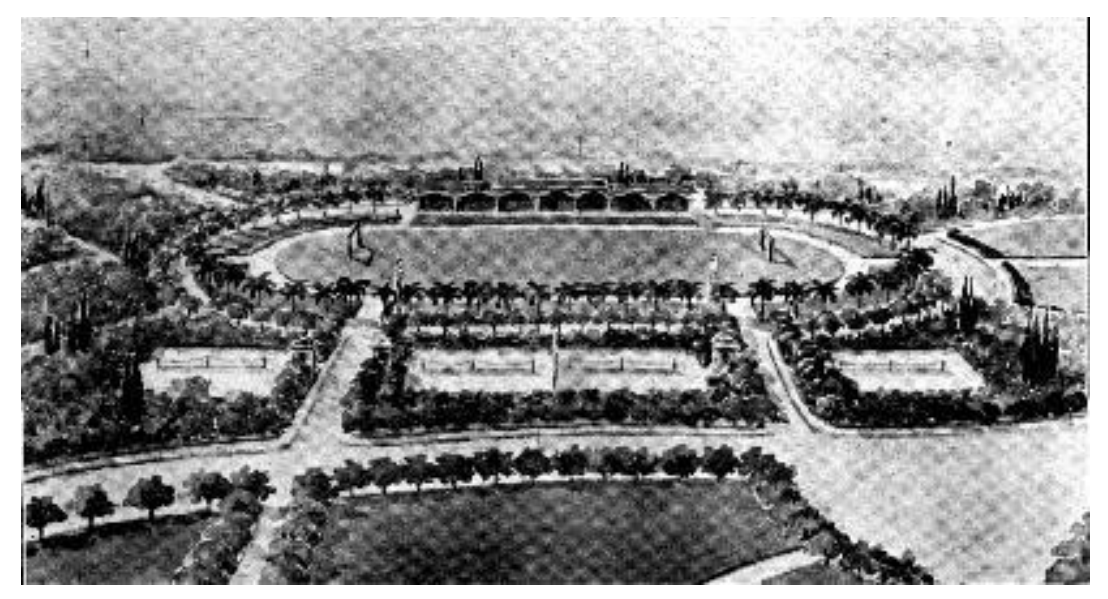

Figura 4 - Projeto Reynaldo Dierberger, 1929: estádio.

Segundo OLIVEIRA, a próxima menção importante sobre esportes feita nos projetos de estruturação do Ibirapuera, ocorreu na consultoria assinada por Christiano Stockler das Neves, durante os preparativos da comemoração do IV Centenário, que projetava o parque "como espaço de recreação belo e agradável à contemplação humana". Stockler foi protagonista de um embate bastante acirrado com Ciccillo Matarazzo, que por discordâncias de preferências artísticas, culminou em disputas políticas dentro da Comissão do IV Centenário, sendo ele presidente da Subcomissão de Obras e Urbanismo, enquanto Ciccillo tornava-se presidente da Comissão, após a 
saída de Arruda Pereira. Assim que tomou posse, Ciccillo passou a impor diversas dificuldades ao planejamento de Stockler.

O Sr. Matarazzo Sobrinho, que não viu com bons olhos a substituição do seu nome pelo meu, na presidência da Subcomissão de Obras e Urbanismo, criou-me toda a sorte de embaraços ao desempenho de minhas funções, não só porque os nossos pontos de vista são diametralmente opostos em matéria de arte, como, também, por já ter a ideia preconcebida de chamar seus amigos arquitetos para todos os planos do IV Centenário. Assim é que criou aquela equipe de arquitetos modernistas, a fim de anular minha ação, por ele considerada altamente prejudicial à 'arte moderna', é óbvio. (Ibidem)

Antes de presidir a Comissão do IV Centenário, Ciccillo pleiteou a presidência da Subcomissão de Obras e Urbanismo. Conforme explanamos no tópico anterior, a influência de Ciccillo nas discussões sobre o Ibirapuera eram sempre decisivas, misturando o público com o particular no trato com os envolvidos nas obras do parque. Sua predileção por Niemeyer escancara essa ingerência de ordem pessoal. Conforme CURI nos mostra, em 1955 foi apresentado à Câmara municipal de São Paulo um projeto de uso do parque após a finalização dos festejos do IV Centenário, que previa intervenções (apesar de sua recentíssima inauguração, no ano anterior), e que

deveria ser confiado a um arquiteto de renome internacional, que organizasse um projeto geral para esse reaproveitamento, respeitada a uniformidade arquitetônica e a grandiosidade com que se apresenta ${ }^{18}$. (CURI, 2018, p. 90)

Acreditamos que o projeto teve influência de Ciccillo e previa a recontratação de Niemeyer para remodelação dos pavilhões e demais construções do parque. Vemos aqui a priorização de laços pessoais sobrepostos ao interesse coletivo, materializados no espaço público. Como elabora Sérgio Buarque (HOLANDA, 1992) no contexto político brasileiro as relações tendem a ser personalizadas. Segundo ele:

O quadro familiar torna-se, assim, tão poderoso e exigente, que sua sombra persegue os indivíduos mesmo fora do recinto doméstico. A entidade privada precede sempre, neles, a

\footnotetext{
${ }^{18}$ Centro Cultural e Expositivo Ibirapuera - Exposição de Motivos_Comissão dos Festejos do IV Centenário, 1954, depositado no Arquivo Histórico Wanda Svevo.
} 
entidade pública. A nostalgia dessa organização compacta, única e intransferível, onde prevalecem necessariamente as preferências fundadas em laços afetivos, não podia deixar de marcar nossa sociedade, nossa vida pública, todas as nossas atividades. Representando, como já se notou acima, o único setor onde o princípio de autoridade é indisputado, a família colonial fornecia a ideia mais normal de poder, da respeitabilidade, da obediência e da coesão entre os homens. $O$ resultado era predominarem, em toda a vida social, sentimentos próprios à comunidade doméstica, naturalmente particularista e antipolítica, uma invasão do público pelo privado, do Estado pela família. (HOLANDA, 1992, p. 50)

Quanto à questão dos esportes, vemos aqui novamente negligência com este potencial do parque. Aproximava-se o fim do trabalho da Comissão do IV Centenário, e entre as discussões sobre sua remodelagem, usos, ocupações e ocupantes, em documento não assinado entregue à câmara municipal de São Paulo, foi proposto a "constituição imediata de duas comissões": uma de "cultura, arte e ciência" e outra, da "indústria e comércio". (CURI, 2018.). O Complexo esportivo e o Velódromo, apesar de fazerem parte do entorno e estarem previstos no projeto de atrações do IV Centenário, só fora inaugurado uma década depois. Nos parece bastante sintomático da priorização dada as artes e, sobretudo, a utilização do parque pelos grandes industriais da cidade, uma vez que se propunha refazer os espaços de uso desses em detrimento da finalização das obras do Complexo Esportivo. 


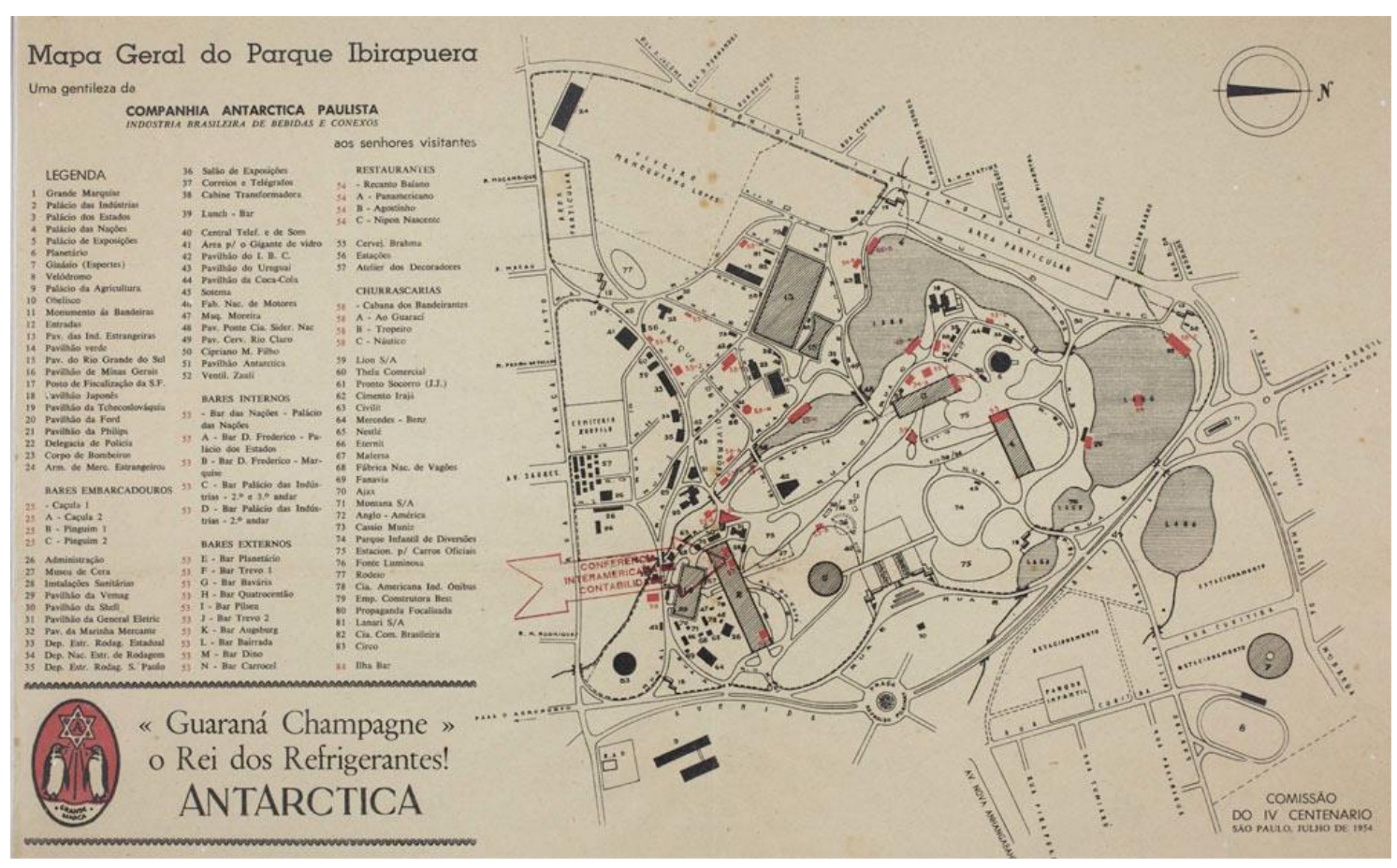

Figura 5 - Mapa Geral do Parque Ibirapuera - Comissão do IV Centenário, São Paulo - 1954. Item 7 - Ginásio; Item 8 Velódromo. http://www.bienal.org.br/post/1089.

\subsection{Complexo Esportivo}

Após a inauguração do parque, o complexo esportivo perdeu importância entre as prioridades da Prefeitura e do Governo do Estado, e passou quase uma década sem grandes incursões do poder público, sendo que o cenário se altera com a demonstração de interesse do exército pela área. As obras e concessões começaram a ser realizadas após o Golpe de 1964.

\subsection{Entre as ruas Manoel da Nóbrega e Abílio Soares}

Durante o governo Adhemar de barros houve três autorizações de obras para o complexo do Ibirapuera. Devemos levar em conta que já existia, previamente ao seu governo equipamentos no complexo, mas ele ganhou "corpo" na sua gestão, após muita polêmica com a Câmara Municipal. Quando foi prefeito de São Paulo, Adhemar de Barros foi acusado de descaso com o lbirapuera, e através de requerimento o vereador Cotyntho Balduíno chegou a pedir a sua responsabilização pelo descaso (CURI, 2018, p. 90). 
No mês seguinte ao golpe, ele autorizou a construção da Praça de Esportes no lbirapuera, situado entre as ruas Manoel da Nóbrega e Abílio Soares, e que em seguida teve a aprovação da Câmara de São Paulo para a cessão do comodato. Vale frisar aqui a mudança de postura do governador, antes muito relapso quanto ao lbirapuera, e após a tomada do governo pelos militares, muito célere nas decisões.

Adhemar de Barros foi um dos articuladores do Golpe de 1964, e incentivador da adesão do II Exército, para o qual construía agora a Praça de Esportes, na sublevação que retirou Jango do poder. Em $1^{\circ}$ de abril, na sede do Palácio do Governo, declarou estar o Estado de São Paulo junto ao II Exército, "Neste instante anuncio ao povo brasileiro que em 6 Estados estamos sublevados, mas para defender a Constituição, para defender os princípios sagrados à nossa tradição histórica" (COUTO, 2007, p.249 f).

Desde 1932, a região passou por um processo de ocupação militar, contudo, a partir de 1961 a discussão foi retomada e o espaço da Praça de Esportes passou a ser cotado para instalação do Quartel General do II Exército.

Não vejo mal algum em cedermos em comodato esta área. $E$ não digo isso por causa da Revolução, porque como V, Exa., também vivo do meu trabalho honesto e da minha profissão, graças a Deus. Faço política apenas para servir ao povo e São Paulo. Entretanto acho que devemos ceder aquela área em comodato, porque se formos construir, amanhã, um parque infantil (por exemplo) ao lado de uma sociedade esportiva daquela natureza, ou um grupo escolar, será sempre um local onde está o Exército. (SÃO PAULO, 1964, n. 112)

O pronunciamento acima foi feito pelo vereador José Dinis, em discussão sobre a concessão ou não do espaço do Ibirapuera ao Exército. Trata-se de um claro aceno de boa vontade com os militares dada a periodização do evento. O que percebemos em sua fala é a subserviência de poderes civis frente aos militares, e a clara concordância com o controle do esporte pelas Forças Militares. 


\section{Diário Oficia \\ ESTADO DE SAO PAULO - (ESTADOS UNIDOS DO BR.ASIL) \\ Diretor: Whandyck VEETIS

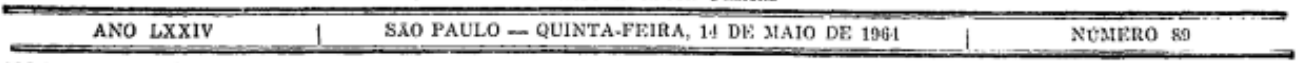

Várias providências importantes em andamento

Prepara-se a Secretaria da Fazenda para cumprir sua parte na execução do PLADI

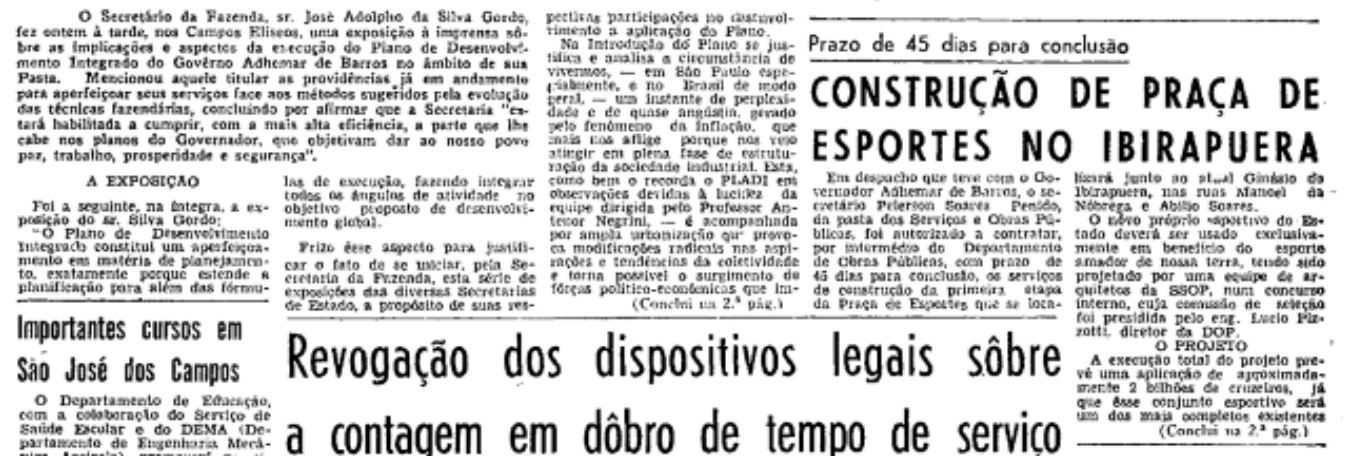

Figura 6 - Capa do Diário Oficial de SP em 14 de maio de 1964. A propaganda evidenciava a pressa na realização da obra que seria, mais tarde, concedida ao II Exército.

Notamos que o lbirapuera era um equipamento que proporcionava grande publicidade positiva para o Governo, visto que no texto da programação anual para 1965 a parte referente ao Departamento de Educação Física e Esportes é aberta com a previsão de incrementos no Conjunto do Ibirapuera (Id., 1965, n. 48), além das publicações de propaganda referente ao novo complexo de recreação infantil construído em 1964. Toda a obra feita no Ibirapuera pelo Poder Executivo culminava em capitalização política pelo Poder Legislativo. Logo após o anúncio de novas obras no complexo, a Assembleia Legislativa votou pela mudança de nome do Ginásio do Ibirapuera para Ginásio Estadual de Esportes Fabio da Silva Prado (Id., 1965, n. 100).

Em seguida, foi autorizada a construção de pista de atletismo no complexo, que resultou na ampliação do projeto para conjunto desportivo, além da reforma do ginásio.

Parece-nos que a construção da pista de atletismo e as melhorias feitas no Conjunto do lbirapuera levavam em conta a possível concessão definitiva do espaço para uso do exército. Se considerarmos o tempo em que a finalização do conjunto ficou parada e discussão exemplificada pela fala do vereador José Diniz, leva-nos a 
crer que que essas obras se tratavam de "agrados" aos militares, e que se previa que comporiam o espaço da sede do II Exército.

\subsection{Complexo Esportivo do Exército}

A partir da Revolução de 1932, o Exército passou a ocupar grandes áreas na região do Ibirapuera, todas pertencentes ao Governo do Estado, e em 1953, uma divisão militar do Rio de Janeiro foi transferia para São Paulo e alocada ao lado da construção do Ginásio, inaugurado em 1957, e ao lado de onde seria a Assembleia Legislativa do Estado de São Paulo. O espaço reservado a Zona Militar, composto pelo Comando Militar Sudeste, Círculo Militar e II Exército, nas imediações do Ibirapuera, fica em parte do terreno onde foi inaugurado, em 1968, o Conjunto Esportivo e a Assembleia (CURI, 2018, p. 90).

Nos chama atenção a localização escolhida pelo para sediar o Exército. Estando em um período em que o poder civil estava sobre tutela dos militares, a Assembleia Legislativa foi inaugurada em janeiro de 1968, e a sede do II Exército em maio do mesmo ano, colocando o governo civil sob vigília militar tanto no campo prático como no simbólico. E, considerando a inauguração do conjunto esportivo para uso militar, podemos ter um retrato do peso que o esporte tinha para exército.

Em 1968, o governador Abreu Sodré autorizou a construção de velódromo no Ibirapuera. Contudo, devido a demandas políticas, o complexo foi inaugurado ainda sem estar terminado, para calhar com a data de 9 de julho daquele ano. $O$ complexo, até então, seria o maior da América Latina. No mesmo ano se inaugurou o conjunto esportivo Constâncio Vaz Guimarães, dentro do Ibirapuera, completando a megaestrutura. A escolha do nome foi elogiada pelo deputado Wadih Helu em pronunciamento na Assembleia Legislativa, ocasião em que enalteceu os dirigentes envolvidos na obra, sobretudo o major Sylvio de Magalhães Padilha, diretor do DEFE (SÃO PAULO, 1968, n. 172).

Importante ressaltarmos que em 1967 a Assembleia Legislativa também começou a discutir a concessão de terras próximas ao conjunto do lbirapuera, e com isso parte do complexo, para o comando do II Exército, o que se concretizou em ato solene em 07 de maio de 1968.

A pressão política para a inauguração do complexo esportivo do Ibirapuera fica clara quando, em 07 de setembro de 1968, Abreu Sodré autoriza em ato executivo a 
prorrogação de prazo para que a empresa Dumes S.A. entregasse a piscina, o vestiário e as arquibancada (ld., 1968, n. 170), que foram inauguradas sem conclusão em 9 de julho. Ainda seguindo com as obras, somente no início de 1969 concluíram parte do melhoramento da acústica do ginásio (Id., 1969, n. 39) e contrataram a Construtora Coan LTDA. para proceder com a pintura dos gigantes e platibandas do ginásio (Id., 1969, n. 70).

\subsubsection{Laudo Natel}

Durante o governo Laudo Natel, a Secretaria de Esporte, Cultura e Turismo firmou convênio com o Fundo de Construção da Universidade de São Paulo - FUNDESP para a construção de quadras na Cidade Universitária, e para elaboração de projeto de ginásio esportivo no lbirapuera, mesmo já havendo esse equipamento e projeto executivo pronto neste complexo (Id., 1972, n. 238). 


\section{CONSIDERAÇÕES FINAIS}

Entendemos que o primeiro passo para se compreender o período da Ditadura Militar no Brasil é considerar a complexidade das relações de poder envolvidas entre governo e sociedade. $\mathrm{O}$ incentivo ao esporte provinha da preocupação dos militares com questões como controle da população, do tempo livre e de lazer, além da preocupação com a aptidão física para o serviço da guerra com a questão do alistamento obrigatório.

O esporte serviu, associado à educação moral e cívica, como ferramenta disciplinadora da população que, quando não era direcionada para práticas militares, servia como educadora dos corpos para o serviço econômico de mão de obra. Além do que, a prática do desporto sempre vem junto, de acordo com cada modalidade, ao ensinamento diário ao respeito a uma série de regras pré-estabelecidas e indiscutíveis, que ajudavam a moldar a mentalidade da população para o não questionamento - característica inerente a qualquer ditadura.

A internalização de valores morais aprendidos no esporte, como o respeito à família, à ordem, à segurança nacional e o amor ao país, contribuía para a obediência da sociedade. O corpo do cidadão não o pertencia de fato, fazia parte de um todo social e por isso precisava ser higienizado, moralizado para contribuir com o projeto de nação idealizado pelos militares.

Além do serviço interno, o esporte servia como propaganda para o mundo do dito "salto civilizatório" pretendido pelo governo militar. A melhoria de atletas para compor os selecionados brasileiros servia como vitrine do Brasil para fora, e como incentivador de um sentimento de pertencimento e orgulho nacionais, duas funções que ajudavam a legitimar os militares no poder.

Sobretudo para os estudantes, o esporte serviu para a constituição de um cidadão moldado dentro de preceitos de higiene, obediência, moralidade e disciplina, servindo ao propósito de nação do governo.

Para além, ou antes, das análises qualitativas das ações de governo frente ao esporte, consideramos aqui a quantidade destas ações. Tendo em vista a quantidade de produções oficiais, legislações e normas referentes ao esporte feitas durante a 
ditadura, o aumento sistemático de equipamentos esportivos e a aplicação da obrigatoriedade da prática esportiva nos estabelecimentos de ensino, podemos notar o cuidado que os militares tiveram com essa temática, destacando pessoal especializado dentro do aparato burocrático que pensava minuciosamente no projeto de esporte nacional, o que reflete claramente a importância do esporte para os militares quanto agente doutrinador - juntava-se ao esporte o apelo referente a moral e ao pertencimento respeitável dentro da sociedade e o do amor ao país.

Notamos, ao longo da pesquisa, que a estrutura autoritária do estado, indo contra todo o moralismo que pregava, permitiu que diversos interesses particularistas fossem atendidos, seguindo a tradição da cultura política brasileira de confundir o público e o privado, e de personalizar em figuras específicas a imagem de salvador, que tudo resolve, mas também tudo pode, como é o caso de Ciccillo Matarazzo e também de Sylvio Magalhães Padilha - o primeiro, que tratou o Parque do Ibirapuera como quintal de casa, e deu pouca importância para as construções esportivas por desinteresse pessoal, e o segundo tendo sido nomeado pelo próprio filho, e homenageado como praticamente o único capaz de dar conta do esporte no estado, nas casas legislativas em mais de uma ocasião.

Com a tomada do poder pelos militares, o esporte foi altamente centralizado para que servisse ao projeto de integração nacional idealizado pela ditadura. No entanto, o discurso passava pela descentralização e desburocratização da área. Fizeram o exato oposto. Muto foi realizado no âmbito das grandes obras, que davam mais visibilidade para o estado. Só no estado de São Paulo, o Pacaembu e o Ibirapuera ganharam investimentos significativos.

Precisamos salientar o caráter de combate ao comunismo que o esporte ganhou durante a ditadura. A propaganda anticomunista está permeada dentro do esporte, sobretudo no escolar. E os atletas medalhistas dos grandes eventos, tratados como heróis nacionais, eram na verdade avessos à política e focados no melhoramento do corpo para exercício do papel de cidadãos que lhes cabia dentro do regime, como foi o caso de Pelé, que nas palavras do deputado Orlando Jurca, "acredito que Pelé, este fabuloso gênio do esporte nacional, é uma pessoa humilde e profundamente compenetrada da sua posição. É um moço que jamais deveria ser envolvido em política”. (SÃO PAULO, 1968, n.148) 
Contudo, ainda hoje é difícil definir o quanto do militarismo continua dentro do esporte brasileiro. Faltam pesquisas nesse sentido, mas podemos supor que grande parte desse projeto ainda se encontra enraizado. Mesmo a apropriação dos símbolos nacionais pelo esporte, e uso de aparatos esportivos em manifestações políticas hoje, pode configurar resquício desse passado. Acreditamos que certa ojeriza e negligência ${ }^{19}$ que as esquerdas nacionais mantiveram e mantêm ainda em determinados setores frente ao esporte também configura uma "contra reprodução" desse passado esportivo militarizado.

\footnotetext{
${ }^{19}$ Essa afirmação é facilmente verificada quando vemos que a pasta do Esporte é sempre uma das primeiras a ser negociada quando da vitória eleitoral de setores da esquerda para cargos executivos, e podemos afirmar que esse é um comportamento padrão em todo o país. Quando não se entrega as secretarias de esporte para setores da direita, com quem se precisa negociar por governabilidade, 0 esporte é entregue à partidos coligados menores, sem grande relutância pelo partido que está assumindo o governo para o qual a pasta se reporta.
} 


\section{FONTES PRIMÁRIAS}

- Ato no 1159.36, art. 500 e 217 da legislação fiscal do município de São Paulo.

- Constituição da República dos Estados Unidos do Brasil, decretada pelo Presidente da República em 10/11/1937.

- Decreto 13.518/61.

- Decreto 69450/71.

- Diagnóstico da Educação física/Desportos no Brasil, Rio de Janeiro, Ministério da Educação e Cultura, Fundação Nacional de Material Escolar, 1971.

- Diário Oficial do Estado de São Paulo - (Estados Unidos do Brasil). Ano LXXIV. São Paulo, terça-feira, 14 de abril de 1964. Número 70.

- Diário Oficial do Estado de São Paulo - (Estados Unidos do Brasil). Ano LXXIV. São Paulo, quarta-feira, 29 de abril de 1964. Número 80.

- Diário Oficial do Estado de São Paulo - (Estados Unidos do Brasil). Ano LXXIV. São Paulo, sexta-feira, 15 de maio de 1964. Número 90.

- Diário Oficial do Estado de São Paulo - (Estados Unidos do Brasil). Ano LXXIV. São Paulo, terça-feira, 19 de maio de 1964. Número 92.

- Diário Oficial do Estado de São Paulo - (Estados Unidos do Brasil). Ano LXXIV. São Paulo, quinta-feira, 14 de maio de 1964. Número 89.

- Diário Oficial do Estado de São Paulo - (Estados Unidos do Brasil). Ano LXXIV. São Paulo, sábado, 23 de maio de 1964. Número 96.

- Diário Oficial do Estado de São Paulo - (Estados Unidos do Brasil). Ano LXXIV. São Paulo, quinta-feira, 16 de julho de 1964. Número 131.

- Diário Oficial do Estado de São Paulo - (Estados Unidos do Brasil). Ano LXXIV. São Paulo, terça-feira, 11 de agosto de 1964. Número 149.

- Diário Oficial do Estado de São Paulo - (Estados Unidos do Brasil). Ano LXXIV. São Paulo, quarta-feira, 26 de agosto de 1964. Número 160.

- Diário Oficial do Estado de São Paulo - (Estados Unidos do Brasil). Ano LXXIV. São Paulo, sexta-feira, 11 de setembro de 1964. Número 171.

- Diário Oficial do Estado de São Paulo - (Estados Unidos do Brasil). Ano LXXIV. São Paulo, quarta-feira, 16 de setembro de 1964. Número 174.

- Diário Oficial do Estado de São Paulo - (Estados Unidos do Brasil). Ano LXXIV. São Paulo, sábado, 19 de setembro de 1964. Número 177.

- Diário Oficial do Estado de São Paulo - (Estados Unidos do Brasil). Ano LXXIV. São Paulo, quarta-feira, 21 de outubro de 1964. Número 198. Projeto do deputado Murilo Sousa Reis.

- Diário Oficial do Estado de São Paulo - (Estados Unidos do Brasil). Ano LXXIV. São Paulo, sexta-feira, 23 de outubro de 1964. Número 200.

- Diário Oficial do Estado de São Paulo - (Estados Unidos do Brasil). Ano LXXIV. São Paulo, sábado, 31 de outubro de 1964. Número 206.

- Diário Oficial do Estado de São Paulo - (Estados Unidos do Brasil). Ano LXXIV. São Paulo, quinta-feira, 10 de novembro de 1964. Número 213. 
- Diário Oficial do Estado de São Paulo - (Estados Unidos do Brasil). Ano LXXIV. São Paulo, terça-feira, 08 de dezembro de 1964. Número 231.

- Diário Oficial do Estado de São Paulo - (Estados Unidos do Brasil). Ano LXXIV. São Paulo, sexta-feira, 11 de dezembro de 1964. Número 233.

- Diário Oficial do Estado de São Paulo - (Estados Unidos do Brasil). Ano LXXV. São Paulo, quarta-feira, 13 de janeiro de 1965. Número 7.

- Diário Oficial do Estado de São Paulo - (Estados Unidos do Brasil). Ano LXXV. São Paulo, terça-feira, 16 de março de 1965. Número 48.

- Diário Oficial do Estado de São Paulo - (Estados Unidos do Brasil). Ano LXXV. São Paulo, quarta-feira, 17 de março de 1965. Número 49.

- Diário Oficial do Estado de São Paulo - (Estados Unidos do Brasil). Ano LXXV. São Paulo, terça-feira, 23 de março de 1965. Número 53.

- Diário Oficial do Estado de São Paulo - (Estados Unidos do Brasil). Ano LXXV. São Paulo, quarta-feira, 12 de maio de 1965. Número 86.

- Diário Oficial do Estado de São Paulo - (Estados Unidos do Brasil). Ano LXXV. São Paulo, sábado, 22 de maio de 1965. Número 94.

- Diário Oficial do Estado de São Paulo - (Estados Unidos do Brasil). Ano LXXV. São Paulo, quarta-feira, 26 de maio de 1965. Número 96.

- Diário Oficial do Estado de São Paulo - (Estados Unidos do Brasil). Ano LXXV. São Paulo, quinta-feira, 27 de maio de 1965. Número 97.

- Diário Oficial do Estado de São Paulo - (Estados Unidos do Brasil). Ano LXXV. São Paulo, quarta-feira, 09 de junho de 1965. Número 105.

- Diário Oficial do Estado de São Paulo - (Estados Unidos do Brasil). Ano LXXV. São Paulo, sábado, 19 de junho de 1965. Número 112.

- Diário Oficial do Estado de São Paulo - (Estados Unidos do Brasil). Ano LXXV. São Paulo, terça-feira, 22 de junho de 1965. Número 113.

- Diário Oficial do Estado de São Paulo - (Estados Unidos do Brasil). Ano LXXV. São Paulo, quarta-feira, 21 de julho de 1965. Número 115.

- Diário Oficial do Estado de São Paulo - (Estados Unidos do Brasil). Ano LXXV. São Paulo, sábado, 07 de agosto de 1965. Número 145.

- Diário Oficial do Estado de São Paulo - (Estados Unidos do Brasil). Ano LXXV. São Paulo, sexta-feira, 22 de outubro de 1965. Número 191.

- Diário Oficial do Estado de São Paulo - (Estados Unidos do Brasil). Ano LXXV. São Paulo, sábado, 18 de dezembro de 1965. Número 234.

- Diário Oficial do Estado de São Paulo - (Estados Unidos do Brasil). Ano LXXV. São Paulo, sexta-feira, 24 de dezembro de 1965. Número 238.

- Diário Oficial do Estado de São Paulo - (Estados Unidos do Brasil). Ano LXXVI. São Paulo, quarta-feira, 05 de janeiro de 1966. Número 235.

- Diário Oficial do Estado de São Paulo - (Estados Unidos do Brasil). Ano LXXVI. São Paulo, quarta-feira, 23 de junho de 1966. Número 115.

- Diário Oficial do Estado de São Paulo - (Estados Unidos do Brasil). Ano LXXVI. São Paulo, quarta-feira, 29 de junho de 1966. Número 119. 
- Diário Oficial do Estado de São Paulo - (Estados Unidos do Brasil). Ano LXXVI. São Paulo, sábado, 06 de agosto de 1966. Número 146.

- Diário Oficial do Estado de São Paulo - (Estados Unidos do Brasil). Ano LXXVI. São Paulo, sexta-feira, 12 de agosto de 1966. Número 160.

- Diário Oficial do Estado de São Paulo - (Estados Unidos do Brasil). Ano LXXVI. São Paulo, quinta-feira, 01 de setembro de 1966. Número 163.

- Diário Oficial do Estado de São Paulo - (Estados Unidos do Brasil). Ano LXXVI. São Paulo, terça-feira, 30 de agosto de 1966. Número 180.

- Diário Oficial do Estado de São Paulo - (Estados Unidos do Brasil). Ano LXXVI. São Paulo, terça-feira, 06 de setembro de 1966. Número 170.

- Diário Oficial do Estado de São Paulo - (Estados Unidos do Brasil). Ano LXXVI. São Paulo, sábado, 28 de setembro de 1966. Número 174.

- Diário Oficial do Estado de São Paulo - (Estados Unidos do Brasil). Ano LXXVI. São Paulo, sexta-feira, 28 de outubro de 1966. Número 202.

- Diário Oficial do Estado de São Paulo - (Estados Unidos do Brasil). Ano LXXVI. São Paulo, quarta-feira, 02 de novembro de 1966. Número 205.

- Diário Oficial do Estado de São Paulo - (Estados Unidos do Brasil). Ano LXXVII. São Paulo, sexta-feira, 05 de maio de 1967. Número 82.

- Diário Oficial do Estado de São Paulo - (Estados Unidos do Brasil). Ano LXXVII. São Paulo, sexta-feira, 09 de junho de 1967. Número 106.

- Diário Oficial do Estado de São Paulo - (Estados Unidos do Brasil). Ano LXXVII. São Paulo, quinta-feira,15 de junho de 1967. Número 110.

- Diário Oficial do Estado de São Paulo - (Estados Unidos do Brasil). Ano LXXVII. São Paulo, sábado, 14 de outubro de 1967. Número 196.

- Diário Oficial do Estado de São Paulo - (Estados Unidos do Brasil). Ano LXXVII. São Paulo, sábado, 04 de novembro de 1967. Número 210.

- Diário Oficial do Estado de São Paulo - (Estados Unidos do Brasil). Ano LXXVII. São Paulo, sexta-feira, 10 de novembro de 1967. Número 214.

- Diário Oficial do Estado de São Paulo - (Estados Unidos do Brasil). Ano LXXVII. São Paulo, terça-feira, 25 de novembro de 1967. Número 225.

- Diário Oficial do Estado de São Paulo - (Estados Unidos do Brasil). Ano LXXVII. São Paulo, quarta-feira, 29 de novembro de 1967. Número 226.

- Diário Oficial do Estado de São Paulo - (Estados Unidos do Brasil). Ano LXXVIII. São Paulo, quarta-feira, 24 de janeiro de 1968. Número 16.

- Diário Oficial do Estado de São Paulo - (Estados Unidos do Brasil). Ano LXXVIII. São Paulo, sexta-feira, 02 de fevereiro de 1968. Número 22.

- Diário Oficial do Estado de São Paulo - (Estados Unidos do Brasil). Ano LXXVIII. São Paulo, quarta-feira, 07 de fevereiro de 1968. Número 25.

- Diário Oficial do Estado de São Paulo - (Estados Unidos do Brasil). Ano LXXVIII. São Paulo, sexta-feira, 05 de abril de 1968. Número 65.

- Diário Oficial do Estado de São Paulo - (Estados Unidos do Brasil). Ano LXXVIII. São Paulo, sexta-feira, 24 de maio de 1968. Número 96. 
- Diário Oficial do Estado de São Paulo - (Estados Unidos do Brasil). Ano LXXVIII. São Paulo, sexta-feira, 31 de maio de 1968. Número 101.

- Diário Oficial do Estado de São Paulo - (Estados Unidos do Brasil). Ano LXXVIII. São Paulo, sexta-feira, 28 de junho de 1968. Número 120.

- Diário Oficial do Estado de São Paulo - (Estados Unidos do Brasil). Ano LXXVIII. São Paulo, quinta-feira, 08 de agosto de 1968. Número 148.

- Diário Oficial do Estado de São Paulo - (Estados Unidos do Brasil). Ano LXXVIII. São Paulo, quarta-feira, 20 de novembro de 1968. Número 221.

- Diário Oficial do Estado de São Paulo - (Estados Unidos do Brasil). Ano LXXVIII. São Paulo, quinta-feira, 19 de dezembro de 1968. Número 212.

- Diário Oficial do Estado de São Paulo - (Estados Unidos do Brasil). Ano LXXIX. São Paulo, terça-feira, 01 de abril de 1969. Número 62.

- Diário Oficial do Estado de São Paulo - (Estados Unidos do Brasil). Ano LXXIX. São Paulo, sexta-feira, 18 de abril de 1969. Número 73.

- Diário Oficial do Estado de São Paulo - (Estados Unidos do Brasil). Ano LXXIX. São Paulo, terça-feira, 27 de maio de 1969. Número 88.

- Diário Oficial do Estado de São Paulo - (Estados Unidos do Brasil). Ano LXXIX. São Paulo, quinta-feira, 05 de junho de 1969. Número 105.

- Diário Oficial do Estado de São Paulo - (Estados Unidos do Brasil). Ano LXXIX. São Paulo, terça-feira, 26 de agosto de 1969. Número 151.

- Diário Oficial do Estado de São Paulo - (Estados Unidos do Brasil). Ano LXXIX. São Paulo, quarta-feira, 15 de outubro de 1969. Número 197.

- Diário Oficial do Estado de São Paulo - (Estados Unidos do Brasil). Ano LXXIX. São Paulo, sábado, 08 de novembro de 1969. Número 215.

- Diário Oficial do Estado de São Paulo - (Estados Unidos do Brasil). Ano LXXX. São Paulo, quinta-feira, 02 de julho de 1970. Número 121.

- Diário Oficial do Estado de São Paulo - (Estados Unidos do Brasil). Ano LXXX. São Paulo, terça-feira, 07 de julho de 1970. Número 124.

- Diário Oficial do Estado de São Paulo - (Estados Unidos do Brasil). Ano LXXX. São Paulo, quinta-feira, 27 de agosto de 1970. Número 160.

- Diário Oficial do Estado de São Paulo - (Estados Unidos do Brasil). Ano LXXXI. São Paulo, quarta-feira, 18 de março de 1971. Número 51.

- Diário Oficial do Estado de São Paulo - (Estados Unidos do Brasil). Ano LXXXI. São Paulo, terça-feira, 23 de março de 1971. Número 54.

- Diário Oficial do Estado de São Paulo - (Estados Unidos do Brasil). Ano LXXXI. São Paulo, sexta-feira, 26 de março de 1971. Número 57.

- Diário Oficial do Estado de São Paulo - (Estados Unidos do Brasil). Ano LXXXI. São Paulo, quarta-feira, 01 de abril de 1971. Número 57.

- Diário Oficial do Estado de São Paulo - (Estados Unidos do Brasil). Ano LXXXI. São Paulo, quinta-feira, 15 de abril de 1971. Número 69.

- Diário Oficial do Estado de São Paulo - (Estados Unidos do Brasil). Ano LXXXI. São Paulo, quarta-feira, 11 de agosto de 1971. Número 150. 
- Diário Oficial do Estado de São Paulo - (Estados Unidos do Brasil). Ano LXXXI. São Paulo, quarta-feira, 17 de agosto de 1971. Número 217.

- Diário Oficial do Estado de São Paulo - (Estados Unidos do Brasil). Ano LXXXI. São Paulo, terça-feira, 26 de outubro de 1971. Número 203.

- Diário Oficial do Estado de São Paulo - (Estados Unidos do Brasil). Ano LXXXII. São Paulo, quarta-feira, 05 abril de 1972. Número 63.

- Diário Oficial do Estado de São Paulo - (Estados Unidos do Brasil). Ano LXXXII. São Paulo, quarta-feira, 07 de junho de 1972. Número 103.

- Diário Oficial do Estado de São Paulo - (Estados Unidos do Brasil). Ano LXXXII. São Paulo, terça-feira, 20 de junho de 1972. Número 114.

- Diário Oficial do Estado de São Paulo - (Estados Unidos do Brasil). Ano LXXXII. São Paulo, quinta-feira, 31 de agosto de 1972. Número 166.

- Diário Oficial do Estado de São Paulo - (Estados Unidos do Brasil). Ano LXXXII. São Paulo, sexta-feira, 20 de outubro de 1972. Número 201.

- Diário Oficial do Estado de São Paulo - (Estados Unidos do Brasil). Ano LXXXII. São Paulo, terça-feira, 14 de novembro de 1972. Número 217.

- Diário Oficial do Estado de São Paulo - (Estados Unidos do Brasil). Ano LXXV. São Paulo, sexta-feira, 4 de junho de 1965. Número 102.

- Diário Oficial do Estado de São Paulo - (Estados Unidos do Brasil). Ano LXXV. São Paulo, sexta-feira, 2 de julho de 1965. Número 120.

- Presidente a época da Federação Paulista de Futebol.

- Diário Oficial do Estado de São Paulo - (Estados Unidos do Brasil). Ano LXXVII. São Paulo, sexta-feira,30 de maio de 1967. Número 98.

- Diário Oficial do Estado de São Paulo - (Estados Unidos do Brasil). Ano LXXVII. São Paulo, terça-feira, 28 de março de 1967. Número 56.

- Diário Oficial do Estado de São Paulo - (Estados Unidos do Brasil). Ano LXXVIII. São Paulo, quarta-feira, 27 de março de 1968. Número 58.

- Diário Oficial do Estado de São Paulo - (Estados Unidos do Brasil). Ano LXXVIII. São Paulo, terça-feira, 18 de junho de 1968. Número 112.

- Diário Oficial do Estado de São Paulo - (Estados Unidos do Brasil). Ano LXXVIII. São Paulo, sexta-feira, 04 de outubro de 1968. Número 189.

- Diário Oficial do Estado de São Paulo - (Estados Unidos do Brasil). Ano LXXIX. São Paulo, sexta-feira, 09 de maio de 1969. Número 86.

- Diário Oficial do Estado de São Paulo - (Estados Unidos do Brasil). Ano LXXIX. São Paulo, sexta-feira, 12 de setembro de 1969. Número 174.

- Diário Oficial do Estado de São Paulo - (Estados Unidos do Brasil). Ano LXXIX. São Paulo, sexta-feira, 24 de setembro de 1969. Número 182.

- Diário Oficial do Estado de São Paulo - (Estados Unidos do Brasil). Ano LXXIX. São Paulo, quarta-feira, 05 de novembro de 1969. Número 212.

- Diário Oficial do Estado de São Paulo - (Estados Unidos do Brasil). Ano LXXIV. São Paulo, quarta-feira, 17 de junho de 1964. Número 112.

- Diário Oficial do Estado de São Paulo - (Estados Unidos do Brasil). Ano LXXV. São Paulo, terça-feira, 16 de março de 1965. Número 48. 
- Diário Oficial do Estado de São Paulo - (Estados Unidos do Brasil). Ano LXXV. São Paulo, quarta-feira, 02 de junho de 1965. Número 100.

- Diário Oficial do Estado de São Paulo - (Estados Unidos do Brasil). Ano LXXVIII. São Paulo, quarta-feira, 11 de setembro de 1968. Número 172.

- Diário Oficial do Estado de São Paulo - (Estados Unidos do Brasil). Ano LXXVIII. São Paulo, sábado, 07 de março de 1968. Número 170.

- Diário Oficial do Estado de São Paulo - (Estados Unidos do Brasil). Ano LXXIX. São Paulo, quinta-feira, 27 de fevereiro de 1969. Número 39.

- Diário Oficial do Estado de São Paulo - (Estados Unidos do Brasil). Ano LXXIX. São Paulo, terça-feira, 18 de março de 1969. Número 52.

- Diário Oficial do Estado de São Paulo - (Estados Unidos do Brasil). Ano LXXIX. São Paulo, terça-feira, 15 de abril de 1969. Número 70.

- Diário Oficial do Estado de São Paulo - (Estados Unidos do Brasil). Ano LXXXII. São Paulo, quinta-feira, 14 de dezembro de 1972. Número 238.

- Diário Oficial do Estado de São Paulo - (Estados Unidos do Brasil). Ano LXXVI. São Paulo, sexta-feira, 26 de agosto de 1966. Número 159.

- Diário Oficial do Estado de São Paulo - (Estados Unidos do Brasil). Ano LXXVIII. São Paulo, terça-feira, 04 de junho de 1966. Número 105.

- Editorial Esporte e Política, do Jornal Estado de São Paulo, in: Diário Oficial do Estado de São Paulo - (Estados Unidos do Brasil). Ano LXXXI. São Paulo, quarta-feira, 11 de agosto de 1971. Número 150.

- Indicação 333-67. Diário Oficial do Estado de São Paulo - (Estados Unidos do Brasil). Ano LXXVII. São Paulo, quarta-feira, 03 de maio de 1967. Número 80.

- LEI № 4.024, de 20/12/1961. Lei de Diretrizes e Bases da Educação Nacional (1961).

- LEI 5.123, DE 20 DE MARÇO DE 1957.

- Mensagem 67. Diário Oficial do Estado de São Paulo - (Estados Unidos do Brasil). Ano LXXV. São Paulo, sábado, 16 de janeiro de 1965. Número 19.

- Mensagem 312/68. Diário Oficial do Estado de São Paulo - (Estados Unidos do Brasil). Ano LXXVIII. São Paulo, sábado, 14 de dezembro de 1968. Número 239.

- Moção 42/68.

- PL 623/65. Diário Oficial do Estado de São Paulo - (Estados Unidos do Brasil). Ano LXXV. São Paulo, quinta-feira, 10 de junho de 1965. Número 106.

- Portaria 58/64. Diário Oficial do Estado de São Paulo - (Estados Unidos do Brasil). Ano LXXIV. São Paulo, terça-feira, 14 de abril de 1964. Número 70

- Projeto de Lei 54/67.

- Requerimento No. 2639. Diário Oficial do Estado de São Paulo - (Estados Unidos do Brasil). Ano XXXIV. São Paulo, terça-feira, 6 de outubro de 1964. Número 188.

- Requerimento D-2826-67. Diário Oficial do Estado de São Paulo - (Estados Unidos do Brasil). Ano LXXVII. São Paulo, quarta-feira, 19 de setembro de 1967. Número 176. 
- Requerimento D-4706-67. Diário Oficial do Estado de São Paulo - (Estados Unidos do Brasil). Ano LXXVII. São Paulo, quinta-feira, 28 de dezembro de 1967. Número 246.

- Requerimento 1536. Diário Oficial do Estado de São Paulo - (Estados Unidos do Brasil). Ano LXXVII. São Paulo, quarta-feira, 29 de novembro de 1967. Número 226.

- Resolução 1.953. Diário Oficial do Estado de São Paulo - (Estados Unidos do Brasil). Ano LXXVII. São Paulo, quinta-feira, 26 de outubro de 1967. Número 204. 


\section{REFERÊNCIAS BIBLIOGRÁFICAS}

AARÃO REIS, Daniel. Ditadura, anistia e reconciliação. Estudos Históricos, Rio de Janeiro, v.23, n.45. 2010.

. Ditadura e democracia no Brasil. Do golpe de 1964 à Constituição de 1988. Rio de Janeiro: Zahar, 2014.

AMERICANO, Jorge. São Paulo Atual (1935 -1962). São Paulo: Ed. Melhoramentos, 1963.

ANDRADE, Manuella Marianna. O Parque do Ibirapuera: 1890 a 1954. Revista Vitruvius, Arquitextos. 051. Ano 05, set. 2004.

. Revista do Arquivo Municipal / Departamento do Patrimônio Histórico. Ano 1, № 1 (1934) - São Paulo: DPH, 1934.

BARTALINI, Vladimir. Parques públicos municipais de São Paulo. Tese (Doutorado). FAUUSP, 2014.

BIANCHI, Alvaro; ALIAGA, Luciana. "Força e consenso como fundamentos do Estado. In: Revista Brasileira de Ciência Política, n.5, Brasília, pp.17-36, jan./jun. 2011.

BOURDIEU, Pierre. O Poder Simbólico. Capítulo II: "Introdução a uma Sociologia Reflexiva”. Rio de Janeiro: Editora Bertrand Brasil S.A., 1989.

. Como é possível ser esportivo? In: BOURDIEU, Pierre. 1983. Questões de sociologia. Rio de Janeiro: Marco Zero. p 136-153.

BRACHT, Valter. Esporte-Estado-Sociedade. Revista Brasileira de Ciências do Esporte. Campinas, vol. 10, no. 2, jan./1989. p. 69-73.

.; ALMEIDA, F. Q. A política de esporte escolar no Brasil: a pseudovalorização da educação física. Revista Brasileira de Ciência do Esporte, Campinas, v. 24, n. 3 , p. 87-101, maio, 2003.

BRASIL. Legislação Desportiva. Brasília: MEC/SEED. Lei no 6.251/75, Política nacional de Educação Física e desportos, plano nacional de Educação Física e desporto-PNED. Brasília: MEC/DED, 1976.

CAMPOS, Pedro Henrique Pedreira. Estranhas catedrais: as empreiteiras brasileiras e a ditadura civil-militar, 1964-1988. Niterói: Eduff, 2014 (reimpressão 2015) - p. 444.

Carta de Stockler ao Governador Lucas Nogueira Garcez, em 19 de janeiro de 1952, citada em OLIVEIRA, Fabiano Lemes. "O Parque do Ibirapuera: Projetos, Modernidades e Modernismos." In: V Seminário DOCOMOMO Brasil: Arquitetura e urbanismo modernos. Projetos e preservação. São Carlos, 2003.

CASTRO, Celso. In corpore sano - os militares e a introdução da educação física no Brasil. Antropolítica, Niterói, RJ, no 2, p.61-78, 1ํsem. 1997.

CHAIA, Vera Lucia Michalany; SADEK, Maria Tereza. Liderança política de Jânio Quadros, 1947 a 1990. 1991. Universidade de São Paulo, São Paulo, 1991.

CHAIM, Aníbal Renan Martinot. A Bola e o Chumbo: Futebol e Política nos anos de chumbo da Ditadura Militar Brasileira. 2014. Dissertação de Mestrado. Departamento 
de Ciência Política da Faculdade de Filosofia, Letras e Ciências Humanas da Universidade de São Paulo.

COELHO, Eurelino. Dois golpes, duas ditaduras. Hist. R., v.20, n.1, p. 120-141, jan. labr. 2015.

COUTO, Ari Marcelo Macedo. Adhemar de Barros: práticas e tensões políticas no poder. 2007.

COUTO, Ronaldo Costa. História indiscreta da ditadura e da abertura: Brasil: 19641985. Rio de Janeiro: Record, 1999. 3. ed.

CUNHA, L. A. A universidade crítica. Rio de Janeiro: Francisco Alves, 1983.

CURI, Fernanda Araujo. Ibirapuera, metáfora urbana. O público/privado em São Paulo. 1954-2017. 2018. Tese Faculdade de Arquitetura e Urbanismo, Universidade de São Paulo, São Paulo, 2018.

DAMATTA, Roberto. A Bola Corre Mais que os Homens. Rio de Janeiro: Rocco, 2006.

Ditadura civil-militar. O Globo, Rio de Janeiro, caderno Prosa \& Verso, 31 mar. 2012.

DREIFUSS, René A. 1964, a conquista do Estado. Petrópolis: Vozes, 1981.

DYE, T. Understanding Public Policy. Englewood Cliffs: N.J.: Prentice Hall, 1984.

EASTON, D. The Political System: An Inquiry into the State of Political Science. New York: Knopf, 1953.

ELIAS, Norbert. Os alemães. A luta pelo poder e a evolução do habitus nos séculos XIX e XX. Rio de Janeiro: Jorge Zahar Editor,1997. p. 44.

; DUNNING, Eric. Desporto y ocio en el proceso de la civilización. México: Fondo de Cultura Económica, 1992. p. 349.

. A busca da excitação. Lisboa: Difel, 1992.

FICO, Carlos. História do Tempo Presente, eventos traumáticos e documentos sensíveis: o caso brasileiro. Varia história, Belo Horizonte, v. 28, n. 47, p. 56, jan./jun. 2012. Disponível em: http://www.scielo.br/pdf/vh/v28n47/03.pdf. Acesso em: 22 set. 2019.

FOUCAULT, Michel. Microfísica do poder. Rio de Janeiro: Edições Graal, 1979, pág.172. Graal, 2010.

História da sexualidade: a vontade de saber. V. 1. São Paulo: Edições

FRANCO JÚNIOR, Hilário. A dança dos deuses - Futebol, sociedade e cultura. São Paulo: Companhia das Letras, 2007.

GASPARI, Elio. A ditadura envergonhada. São Paulo: Companhia das Letras, 2002. . A Ditadura escancarada. São Paulo: Companhia das Letras, 2002. A Ditadura derrotada. São Paulo: Companhia das Letras, 2002. 
. A Ditadura encurralada. São Paulo: Companhia das Letras, 2002.

A Ditadura acabada. São Paulo: Companhia das Letras, 2002.

GERMANO, J. W. Estado Militar e Educação no Brasil:1964/1985 - Um Estudo sobre a Política Educacional. $461 \mathrm{f}$. Tese de doutorado em Educação - Faculdade de Educação, Universidade Estadual de Campinas, 19 de dezembro de 1990.

GRAMSCI, Antonio. Cadernos do cárcere. Introdução ao estudo da filosofia. A filosofia de Benedetto Croce. Rio de Janeiro: Civilização Brasileira, 2001. v.1.

. Cadernos do cárcere. Maquiavel. Notas sobre o Estado e a política. Rio de Janeiro: Civilização Brasileira, 2000. v. 3.

HUIZINGA, Johan. Homo Ludens: o Jogo como Elemento na Cultura (1938). São. Paulo: Perspectiva, 2008.

Informativo Arquivo Histórico Municipal, São Paulo janeiro/fevereiro /2006 - PMSP SMC-SPH

LENHARDT, G. \& OFFE, C. Teoria do Estado e Política Social: Tentativas de Explicação Político-Sociológica para as Funções e os Processos Inovadores da Política Social. In: Problemas Estruturais do Estado Capitalista (OFFE, C., org.). Rio de Janeiro: Tempo Brasileiro, 1984, p. 10-53.

LINHALES, Meily Assbú. A trajetória política do esporte no Brasil: Interesses envolvidos, setores excluídos. 1996. 242 p. Dissertação de Mestrado. Faculdade de Filosofia e Ciências Humanas da UFMG.

MANHÃES, Eduardo Dias. Políticas de esportes no Brasil. 2. ed. Rio de Janeiro: Paz e Terra, 2002.

LUDOPÉDIO, Equipe. Roberto DaMatta. Ludopédio, São Paulo, v. 03, n. 12, 2010.

MATTOS, Pablo de Oliveira. Para Aonde Vamos? Crise e Democracia no Governo João Goulart 1961-1964. Rio de Janeiro. 2019.

MELO, Demian Bezerra de. A miséria da historiografia. Outubro (São Paulo). São Paulo, v. 14. 2006.

. O golpe de 1964 e meio século de controvérsias: o estado atual da questão. In. MELO, Demian Bezerra de (org.). A miséria da historiografia: uma crítica ao revisionismo contemporâneo. Rio de Janeiro: Consequência, 2014a.

. A opinião pública às vésperas do golpe de 1964. Marx e o Marxismo, Niterói, v.2, pp.214-216, $2014 b$.

. A questão do consenso na ditadura militar brasileira: apontamentos a partir de Gramsci. In: Colóquio Marx Engels. Rio de Janeiro. p.3. 2015.

. Ditadura "Civil-Militar"?: Controvérsias historiográficas sobre o processo político brasileiro no pós-1964 e os desafios do tempo presente. In: Dossiê Ditaduras de Segurança Nacional e Terrorismo de Estado. Rio de Janeiro, 2012. 
MELO, Marcelo Paula de. Políticas de Esporte e Lazer, Políticas Sociais e Teoria de Estado: em defesa da história. Licere, Belo Horizonte, v.16, n.3, set. 2013.

OLIVEIRA, Fabiano Lemes. "O Parque do Ibirapuera: Projetos, Modernidades e Modernismos." In: V Seminário DOCOMOMO Brasil: Arquitetura e urbanismo modernos. Projetos e preservação. São Carlos, 2003.

OLIVEIRA, Marcos Aurélio Taborda de. O esporte brasileiro em tempos de exceção; sob a égide da ditadura militar (1964-1985). In: DEL PRIORE, Mary; MELO, Victor Andrade de (Orgs.). História dos esportes no Brasil: do império aos dias atuais. São Paulo: UNESP, 2009.

- Esporte e política na ditadura militar brasileira: a criação de um pertencimento nacional esportivo, 2012.

POULANTZAS, Nicos. O Estado, o poder, o socialismo. Rio de Janeiro: Graal, 2000.

Projeto Integrado do Arquivo Público do Estado de São Paulo e Universidade de São Paulo.

REIS, D.A. Ditadura Militar, Esquerdas e Sociedade. Rio de Janeiro: Jorge Zahar, 2000.

Revista do Arquivo Municipal / Departamento do Patrimônio Histórico. Ano 1, no 1 (1934) - São Paulo: DPH, 1934 - Ante Projeto da Exposição do IV Centenário de São Paulo. 1952. Acervo: Divisão do Arquivo Histórico Municipal "Washington Luís" $\mathrm{DPH} / \mathrm{SMC}$. Original na FAU/USP.

SANTOS, Wanderley Guilherme dos. Fronteiras do Estado Mínimo: indicações sobre o híbrido institucional brasileiro. Razões da Desordem. Rio de Janeiro: Rocco, 1993.

SCHULTZ, T. W. O valor econômico da educação. Trad. de P.S. Werneck. Rev. Técnica de C.A. Pajuaba. Rio de Janeiro: Zahar, 1967

SKIDMORE, Thomas. Brasil: de Castelo a Tancredo. Rio de Janeiro: Paz e Terra, 1988.

SOARES, Carmem Lúcia. Imagens da educação no corpo: estudos da ginástica francesa no século XIX. Campinas: Autores associados, 2005.

Escultura da carne: o bem-estar e as pedagogias totalitárias do corpo. In: RAGO, Margareth; VEIGA-NETO, Alfredo (Orgs.). Para uma vida não-fascista. Belo Horizonte: Autêntica Editora, 2009.

SOUSA, Reginaldo Cerqueira. Práticas de esporte, educação física e educação moral e cívica na ditadura militar: uma higiene moral e do corpo. In: Recorte - revista eletrônica - Mestrado em Letras: Linguagem, Cultura e Discurso / UNINCOR V. 12 n. 1, jan./jun. 2015.

SOUZA, Ângelo Ricardo; TAVARES, Taís Moura. A gestão educacional no Brasil: os legados da ditadura. RBPAE - v.30, n. 2, p. 269-285, mai./ago. 2014.

SOUZA, C. Políticas públicas: uma revisão da literatura. In: Sociologias, Porto Alegre, n. 16, ano 8, p. 20-45, jul-dez, 2006. 
ANEXO

LEVANTAMENTO FEITO A PARTIR DO DIÁRIO OFICIAL COM CLASSIFICAÇÃO POR TIPO DE DOCUMENTO 


\begin{tabular}{|c|c|c|c|c|c|}
\hline Data & Órgão & Tipo & Subcategoria & Identificação & Descrição \\
\hline $\begin{array}{l}10 \text { de } \\
\text { abril de } \\
1964\end{array}$ & $\begin{array}{l}\text { Câmara } \\
\text { Municipal de } \\
\text { São Paulo } \\
\end{array}$ & Pronunciamento & Discussão & & $\begin{array}{l}\text { Os vereadores } \\
\text { debatem sobre a } \\
\text { proibição feita pelos } \\
\text { clubes para que o } \\
\text { rádio e a tv } \\
\text { transmitissem ao } \\
\text { vivo os jogos do } \\
\text { Torneio Rio-SP. }\end{array}$ \\
\hline $\begin{array}{l}14 \text { de } \\
\text { abril de } \\
1964\end{array}$ & $\begin{array}{l}\text { Governo do } \\
\text { Estado de } \\
\text { São Paulo }\end{array}$ & Ato executivo & Portaria & $\begin{array}{l}58 \text { de } 13 \text { de abril } \\
\text { de } 64\end{array}$ & $\begin{array}{l}\text { A diretoria de } \\
\text { educação do Estado } \\
\text { de São Paulo acata } \\
\text { uma representação } \\
\text { feita pela Associação } \\
\text { de Professores de } \\
\text { Educação Física e } \\
\text { inclui mais uma aula } \\
\text { na grade estadual do } \\
\text { colegial, atendendo } \\
\text { portaria } 20 \text { de } 17 \text { de } \\
\text { fevereiro de } 1964 .\end{array}$ \\
\hline $\begin{array}{l}29 \text { de } \\
\text { abril de } \\
1964\end{array}$ & $\begin{array}{l}\text { Governo do } \\
\text { Estado de } \\
\text { São Paulo }\end{array}$ & $\begin{array}{l}\text { Notícia do } \\
\text { Executivo }\end{array}$ & Publicidade & & $\begin{array}{l}\text { Encontro dos } \\
\text { esportistas do } \\
\text { Estado de São Paulo } \\
\text { para homenagear o } \\
\text { governador Adhemar } \\
\text { de Barros, sobretudo } \\
\text { pela sua atuação no } \\
\text { golpe. }\end{array}$ \\
\hline $\begin{array}{l}14 \text { de } \\
\text { maio de } \\
1964\end{array}$ & $\begin{array}{l}\text { Governo do } \\
\text { Estado de } \\
\text { São Paulo }\end{array}$ & Ato executivo & & & $\begin{array}{l}\text { Adhemar de Barros } \\
\text { autoriza a construção } \\
\text { de Praça de Esporte } \\
\text { no Ibirapuera, entre } \\
\text { as ruas Manuel da } \\
\text { Nobrega e Abílio } \\
\text { Soares. }\end{array}$ \\
\hline $\begin{array}{l}15 \text { de } \\
\text { maio de } \\
1964\end{array}$ & $\begin{array}{l}\text { Governo do } \\
\text { Estado de } \\
\text { São Paulo } \\
\end{array}$ & Ato executivo & Autorização de obra & & $\begin{array}{l}\text { Adhemar de Barros } \\
\text { autoriza a construção } \\
\text { de } 33 \text { quadras de } \\
\text { esportes no Estado } \\
\text { de São Paulo, } \\
\text { espalhadas em } \\
\text { escolas da Rede. }\end{array}$ \\
\hline $\begin{array}{l}19 \text { de } \\
\text { maio de } \\
1964\end{array}$ & $\begin{array}{l}\text { Governo do } \\
\text { Estado de } \\
\text { São Paulo }\end{array}$ & Ato executivo & $\begin{array}{l}\text { Submissão ao Chefe } \\
\text { de Governo }\end{array}$ & & $\begin{array}{l}\text { Departamento de } \\
\text { Obras do Estado } \\
\text { submete ao } \\
\text { governador o } \\
\text { resultado da licitação } \\
\text { feita em } 3 \text { de março } \\
\text { de } 1964, \text { visando a } \\
\text { construção de } 48 \\
\text { quadras esportivas } \\
\text { na rede de ensino do } \\
\text { Estado, na qual } \\
\text { apareceu um único } \\
\text { concorrente, } \\
\text { superando o valor } \\
\text { estimado no Decreto } \\
\text { no } 42.053 / 63 \text { (este } \\
\text { decreto prevê ajuste } \\
\text { no preço). }\end{array}$ \\
\hline
\end{tabular}




\begin{tabular}{|c|c|c|c|c|c|}
\hline $\begin{array}{l}19 \text { de } \\
\text { maio de } \\
1964\end{array}$ & \begin{tabular}{|l} 
Governo do \\
Estado de \\
São Paulo
\end{tabular} & Ato executivo & $\begin{array}{l}\text { Submissão ao Chefe } \\
\text { de Governo }\end{array}$ & & $\begin{array}{l}\text { Departamento de } \\
\text { Obras do Estado } \\
\text { submete ao } \\
\text { governador o } \\
\text { resultado da licitação } \\
\text { feita em } 30 \text { de março } \\
\text { de } 1964, \text { visando a } \\
\text { construção de } 21 \\
\text { quadras esportivas } \\
\text { na rede de ensino do } \\
\text { estado, na qual } \\
\text { apareceu um único } \\
\text { concorrente, } \\
\text { superando o valor } \\
\text { estimado no Decreto } \\
\text { no } 42.053 / 63 \text { (este } \\
\text { decreto prevê ajuste } \\
\text { no preço). }\end{array}$ \\
\hline $\begin{array}{l}23 \text { de } \\
\text { maio de } \\
1964\end{array}$ & $\begin{array}{l}\text { Câmara } \\
\text { Municipal de } \\
\text { São Paulo }\end{array}$ & $\begin{array}{l}\text { Pronunciamen } \\
\text { to }\end{array}$ & $\begin{array}{l}\text { Pronunciamento } \\
\text { na Câmara de SP }\end{array}$ & $\begin{array}{l}\text { Vereador } \\
\text { Galdino do } \\
\text { Santos }\end{array}$ & $\begin{array}{l}\text { O vereador se } \\
\text { pronunciou sobre } \\
\text { manifestação } \\
\text { evangélica de } \\
\text { apoio ao governo } \\
\text { ocorrida dia } 17 \text { de } \\
\text { maio, dentro no } \\
\text { estádio do } \\
\text { Pacaembu. }\end{array}$ \\
\hline $\begin{array}{l}9 \text { de } \\
\text { junho de } \\
1964\end{array}$ & $\begin{array}{l}\text { Câmara } \\
\text { Municipal de } \\
\text { São Paulo }\end{array}$ & Ato executivo & $\begin{array}{l}\text { Liberação } \\
\text { orçamentária }\end{array}$ & $\begin{array}{l}\text { Comissão } \\
\text { Central de } \\
\text { Orçamento - } \\
\text { Processos } \\
\text { julgados em } 2 \text { de } \\
\text { junho de } 1961\end{array}$ & \begin{tabular}{|l} 
Liberação de R\$ \\
$2.306 .918,00$ de \\
cruzeiros para o \\
Departamento de \\
Educação Física e \\
Esportes do \\
Estado de São \\
Paulo.
\end{tabular} \\
\hline $\begin{array}{l}10 \text { de } \\
\text { junho de } \\
1964\end{array}$ & $\begin{array}{l}\text { Câmara } \\
\text { Municipal de } \\
\text { São Paulo }\end{array}$ & $\begin{array}{l}\text { Pronunciamen } \\
\text { to }\end{array}$ & Nota de Pesar & & $\begin{array}{l}\text { Nota pública de } \\
\text { pesar pela morte } \\
\text { do jornalista } \\
\text { Ferdinando } \\
\text { Panattore da } \\
\text { Gazeta Esportiva. }\end{array}$ \\
\hline $\begin{array}{l}17 \text { de } \\
\text { junho de } \\
1964\end{array}$ & $\begin{array}{l}\text { Assembleia } \\
\text { Legislativa } \\
\text { de São } \\
\text { Paulo } \\
\end{array}$ & $\begin{array}{l}\text { Pronunciamen } \\
\text { to }\end{array}$ & Discussão & & $\begin{array}{l}\text { Discussão sobre a } \\
\text { concessão de } \\
\text { terras próximas ao } \\
\text { lbirapuera para o II } \\
\text { Exército }\end{array}$ \\
\hline $\begin{array}{l}9 \text { de } \\
\text { julho de } \\
1964 \\
\end{array}$ & $\begin{array}{l}\text { Governo do } \\
\text { Estado de } \\
\text { São Paulo } \\
\end{array}$ & Ato executivo & Decreto & $13.518 / 61$ & $\begin{array}{l}\text { Ordem executiva } \\
\text { para } \\
\text { desapropriação de } \\
\text { terra em Itápolis } \\
\text { para construção de } \\
\text { Praça de Esportes } \\
\text { do Instituto de } \\
\text { Educação } \\
\text { "Valentim Gentil". } \\
\end{array}$ \\
\hline \begin{tabular}{|l}
16 de \\
julho de \\
1964
\end{tabular} & $\begin{array}{l}\text { Governo do } \\
\text { Estado de } \\
\text { São Paulo }\end{array}$ & Ato executivo & $\begin{array}{l}\text { Liberação } \\
\text { orçamentária }\end{array}$ & & \begin{tabular}{|l|} 
Liberação de $\mathrm{R} \$$ \\
$350.000,00$ de \\
cruzeiros para a \\
Associação Atlética \\
Samambaia, Vila \\
Samambaia, para \\
a construção de \\
Praça de Esportes.
\end{tabular} \\
\hline $\begin{array}{l}11 \text { de } \\
\text { agosto } \\
\text { de } 1964\end{array}$ & $\begin{array}{l}\text { Assembleia } \\
\text { Legislativa } \\
\text { de São } \\
\text { Paulo }\end{array}$ & Projeto de Lei & Parecer & & $\begin{array}{l}\text { Parecer favorável } \\
\text { ao projeto de lei do } \\
\text { deputado Leonidas } \\
\text { Umburama, para a } \\
\text { criação de Praça } \\
\text { de Esportes em }\end{array}$ \\
\hline
\end{tabular}




\begin{tabular}{|c|c|c|c|c|c|}
\hline & & & & & $\begin{array}{l}\text { Presidente } \\
\text { Prudente. }\end{array}$ \\
\hline $\begin{array}{l}12 \text { de } \\
\text { agosto } \\
\text { de } 1964\end{array}$ & $\begin{array}{l}\text { Assembleia } \\
\text { Legislativa } \\
\text { de São } \\
\text { Paulo } \\
\end{array}$ & $\begin{array}{l}\text { Pronunciamen } \\
\text { to }\end{array}$ & Nota de louvor & & $\begin{array}{l}\text { Nota de louvor feita } \\
\text { no plenário pela } \\
\text { realização dos VIII } \\
\text { Jogos Regionais } \\
\text { de Araraquara. }\end{array}$ \\
\hline $\begin{array}{l}26 \text { de } \\
\text { agosto } \\
\text { de } 1964\end{array}$ & $\begin{array}{l}\text { Câmara } \\
\text { Municipal de } \\
\text { São Paulo }\end{array}$ & $\begin{array}{l}\text { Pronunciamen } \\
\text { to }\end{array}$ & Ao Executivo & & $\begin{array}{l}\text { Vereador Jayme } \\
\text { Rodrigues pede ao } \\
\text { Prefeito da cidade } \\
\text { São Paulo, } \\
\text { formalmente, a } \\
\text { construção de um } \\
\text { Estádio Distrital no } \\
\text { bairro da Lapa. } \\
\end{array}$ \\
\hline $\begin{array}{l}27 \text { de } \\
\text { agosto } \\
\text { de } 1964\end{array}$ & $\begin{array}{l}\text { Assembleia } \\
\text { Legislativa } \\
\text { de São } \\
\text { Paulo }\end{array}$ & Requerimento & Votação & $\mathrm{S} / \mathrm{N}$ & $\begin{array}{l}\text { Votação de } \\
\text { congratulação na } \\
\text { Ata do dia ao } \\
\text { Palmeiras, pelos } \\
\text { seus } 50 \text { anos. }\end{array}$ \\
\hline $\begin{array}{l}11 \text { de } \\
\text { setembr } \\
\text { o de } \\
1964 \\
\end{array}$ & $\begin{array}{l}\text { Assembleia } \\
\text { Legislativa } \\
\text { de São } \\
\text { Paulo }\end{array}$ & $\begin{array}{l}\text { Pronunciamen } \\
\text { to }\end{array}$ & Discussão & $\mathrm{S} / \mathrm{N}$ & $\begin{array}{l}\text { Deputado Valerio } \\
\text { Giuli apresenta na } \\
\text { Assembleia } \\
\text { discussão sobre a } \\
\text { falta de recursos } \\
\text { para o DEFE. }\end{array}$ \\
\hline $\begin{array}{l}16 \text { de } \\
\text { setembr } \\
\text { o de } \\
1964\end{array}$ & $\begin{array}{l}\text { Assembleia } \\
\text { Legislativa } \\
\text { de São } \\
\text { Paulo }\end{array}$ & $\begin{array}{l}\text { Pronunciamen } \\
\text { to }\end{array}$ & & $\mathrm{S} / \mathrm{N}$ & $\begin{array}{l}\text { Deputado Paulo } \\
\text { Planet Buarque } \\
\text { elogia o } \\
\text { acontecimento da } \\
\text { Olimpíada } \\
\text { Colegial, exaltando } \\
\text { a Figura do Major } \\
\text { Silvio Magalhães } \\
\text { Padilha e do } \\
\text { DEFE, fazendo } \\
\text { alusão à raça, } \\
\text { civismo e } \\
\text { reforçando a } \\
\text { necessidade do } \\
\text { aumento de verba } \\
\text { para o } \\
\text { departamento. }\end{array}$ \\
\hline $\begin{array}{l}19 \text { de } \\
\text { setembr } \\
\text { o de } \\
1964 \\
\end{array}$ & $\begin{array}{l}\text { Governo do } \\
\text { Estado de } \\
\text { São Paulo }\end{array}$ & Ato executivo & Autorização & TC.391664 & $\begin{array}{l}\text { Autorização para } \\
\text { contratação da } \\
\text { empresa } \\
\text { Albuquerque e } \\
\text { Takaoka para a } \\
\text { construção de } 33 \\
\text { quadras } \\
\text { esportivas, } \\
\text { conforme licitação } \\
\text { de março. } \\
\end{array}$ \\
\hline $\begin{array}{l}19 \text { de } \\
\text { setembr } \\
\text { o de } \\
1964\end{array}$ & $\begin{array}{l}\text { Governo do } \\
\text { Estado de } \\
\text { São Paulo } \\
\end{array}$ & Ato executivo & Autorização & TC.383764 & $\begin{array}{l}\text { Autorização para } \\
\text { contratação da } \\
\text { empresa } \\
\text { Albuquerque e } \\
\text { Takaoka para a } \\
\end{array}$ \\
\hline
\end{tabular}




\begin{tabular}{|c|c|c|c|c|c|}
\hline & & & & & $\begin{array}{l}\text { construção de } 48 \\
\text { quadras } \\
\text { esportivas, } \\
\text { conforme licitação } \\
\text { de março. }\end{array}$ \\
\hline $\begin{array}{l}19 \text { de } \\
\text { setembr } \\
\text { o de } \\
1964\end{array}$ & $\begin{array}{l}\text { Governo do } \\
\text { Estado de } \\
\text { São Paulo }\end{array}$ & Projeto de Lei & Discussão & 1099 de 64 & \begin{tabular}{|l} 
Discussão sobre \\
projeto de lei que \\
previa criação do \\
estádio regional no \\
município de \\
Avaré.
\end{tabular} \\
\hline $\begin{array}{l}30 \text { de } \\
\text { setembr } \\
\text { o de } \\
1964\end{array}$ & $\begin{array}{l}\text { Assembleia } \\
\text { Legislativa } \\
\text { de São } \\
\text { Paulo }\end{array}$ & Projeto de Lei & Discussão & $1112 / 64$ & $\begin{array}{l}\text { Dispõe sobre a } \\
\text { entrega de } \\
\text { comprovante de } \\
\text { pagamento de } \\
\text { ingressos de } \\
\text { espetáculos } \\
\text { públicos, incluindo } \\
\text { os de esporte. }\end{array}$ \\
\hline $\begin{array}{l}06 \text { de } \\
\text { outubro } \\
\text { de } 1964\end{array}$ & $\begin{array}{l}\text { Câmara } \\
\text { Municipal de } \\
\text { São Paulo }\end{array}$ & $\begin{array}{l}\text { Pronunciamen } \\
\text { to }\end{array}$ & Ao Executivo & $\mathrm{S} / \mathrm{N}$ & $\begin{array}{l}\text { Vereador Marcos } \\
\text { Reimam pede } \\
\text { informações sobre } \\
\text { o aumento do } \\
\text { aluguel pago pelos } \\
\text { clubes amadores } \\
\text { no Ginásio do } \\
\text { Pacaembu, que } \\
\text { subiu de } R \$ \\
6000,00 \text { para } R \$ \\
18000,00 \text {. }\end{array}$ \\
\hline \begin{tabular}{|l|}
14 de \\
outubro \\
de 1964 \\
\end{tabular} & \begin{tabular}{|l|} 
Câmara \\
Municipal de \\
São Paulo \\
\end{tabular} & $\begin{array}{l}\text { Pronunciamen } \\
\text { to }\end{array}$ & Homenagem & $\mathrm{S} / \mathrm{N}$ & $\begin{array}{l}\text { Homenagem à } \\
\text { desportista Maria } \\
\text { Esther Bueno. } \\
\end{array}$ \\
\hline $\begin{array}{l}16 \text { de } \\
\text { outubro } \\
\text { de } 1964\end{array}$ & $\begin{array}{l}\text { Tribunal de } \\
\text { Contas }\end{array}$ & Ato executivo & Diligência & TC.391664 & $\begin{array}{l}\text { Autorização para } \\
\text { contratação da } \\
\text { empresa } \\
\text { Albuquerque e } \\
\text { Takaoka para a } \\
\text { construção de } 21 \\
\text { quadras } \\
\text { esportivas, } \\
\text { conforme licitação } \\
\text { de março. } \\
\end{array}$ \\
\hline \begin{tabular}{|l|}
16 de \\
outubro \\
de 1964 \\
\end{tabular} & \begin{tabular}{|l} 
Câmara \\
Municipal de \\
São Paulo \\
\end{tabular} & $\begin{array}{l}\text { Pronunciamen } \\
\text { to }\end{array}$ & Homenagem & $\mathrm{S} / \mathrm{N}$ & \begin{tabular}{|l|} 
Homenagem à \\
desportista Maria \\
Esther Bueno. \\
\end{tabular} \\
\hline $\begin{array}{l}16 \text { de } \\
\text { outubro } \\
\text { de } 1964\end{array}$ & $\begin{array}{l}\text { Tribunal de } \\
\text { Contas }\end{array}$ & Ato executivo & Diligência & & $\begin{array}{l}\text { Autorização para } \\
\text { contratação da } \\
\text { empresa } \\
\text { Albuquerque e } \\
\text { Takaoka para a } \\
\text { construção de } 33 \\
\text { quadras } \\
\text { esportivas, } \\
\text { conforme licitação } \\
\text { de marco. }\end{array}$ \\
\hline $\begin{array}{l}21 \text { de } \\
\text { outubro } \\
\text { de } 1964\end{array}$ & $\begin{array}{l}\text { Assembleia } \\
\text { Legislativa } \\
\text { de São } \\
\text { Paulo }\end{array}$ & Projeto de Lei & Discussão & 1846.63 & $\begin{array}{l}\text { Discussão sobre } \\
\text { projeto de lei do } \\
\text { deputado Murillo } \\
\text { Sousa Reis sobre }\end{array}$ \\
\hline
\end{tabular}




\begin{tabular}{|c|c|c|c|c|c|}
\hline & & & & & $\begin{array}{l}\text { a criação de } \\
\text { estádio regional de } \\
\text { esportes em } \\
\text { Araçatuba. }\end{array}$ \\
\hline $\begin{array}{l}23 \text { de } \\
\text { outubro } \\
\text { de } 1964\end{array}$ & $\begin{array}{l}\text { Assembleia } \\
\text { Legislativa } \\
\text { de São } \\
\text { Paulo }\end{array}$ & Projeto de Lei & Discussão & 1846.63 & $\begin{array}{l}\text { Discussão sobre } \\
\text { projeto de lei do } \\
\text { deputado Murillo } \\
\text { Sousa Reis sobre } \\
\text { a criação de } \\
\text { estádio regional de } \\
\text { esportes em } \\
\text { Araçatuba. }\end{array}$ \\
\hline $\begin{array}{l}23 \text { de } \\
\text { outubro } \\
\text { de } 1964\end{array}$ & \begin{tabular}{|l} 
Assembleia \\
Legislativa \\
de São \\
Paulo \\
\end{tabular} & Projeto de Lei & $\begin{array}{l}\text { Apresentado pelo } \\
\text { executivo }\end{array}$ & $1287 / 64$ & $\begin{array}{l}\text { Apresentado pelo } \\
\text { executivo, este } \\
\text { projeto previa que } \\
\text { o Estado } \\
\text { disponibilizasse } \mathrm{R} \$ \\
50.000,00 \text { para o } \\
\text { Comitê Olímpico } \\
\text { Brasileiro, visando } \\
\text { ajudar nas } \\
\text { olimpíadas de } \\
\text { Tóquio, } \\
\text { estimulando o } \\
\text { esporte amador. }\end{array}$ \\
\hline \begin{tabular}{|l}
23 de \\
outubro \\
de 1964
\end{tabular} & $\begin{array}{l}\text { Assembleia } \\
\text { Legislativa } \\
\text { de São } \\
\text { Paulo } \\
\end{array}$ & Projeto de Lei & Parecer & $1846 / 64$ & $\begin{array}{l}\text { Parecer Negativo } \\
\text { ao projeto de lei do } \\
\text { deputado Orlando } \\
\text { Jurca, que previa } \\
\text { abarcar crédito } \\
\text { adicional ao } \\
\text { esporte no estado. } \\
\text { Foi aprovado pela } \\
\text { Assembleia e } \\
\text { negado por outro } \\
\text { órgão, sendo que } \\
\text { virou mero } \\
\text { indicativo. }\end{array}$ \\
\hline $\begin{array}{l}31 \text { de } \\
\text { outubro } \\
\text { de } 1964\end{array}$ & $\begin{array}{l}\text { Assembleia } \\
\text { Legislativa } \\
\text { de São } \\
\text { Paulo } \\
\end{array}$ & Projeto de Lei & Parecer & $693 / 63$ & $\begin{array}{l}\text { Parecer favorável } \\
\text { ao projeto de lei do } \\
\text { deputado Leoncio } \\
\text { Ferraz Junior, que } \\
\text { visava a } \\
\text { construção de } \\
\text { estádios distritais } \\
\text { nos bairros de } \\
\text { Itaim Bibi, Vila } \\
\text { Matilde, Vila } \\
\text { Califórnia e } \\
\text { Itaquera. }\end{array}$ \\
\hline $\begin{array}{l}06 \text { de } \\
\text { novembr } \\
\text { o de } \\
1964 \\
\end{array}$ & $\begin{array}{l}\text { Câmara } \\
\text { Municipal de } \\
\text { São Paulo } \\
\end{array}$ & Resolução & & & $\begin{array}{l}\text { Confecção de } \\
\text { placa ao Palmeiras } \\
\text { pelos } 50 \text { anos. }\end{array}$ \\
\hline \begin{tabular}{|l|}
10 de \\
novembr \\
o de \\
1964 \\
\end{tabular} & $\begin{array}{l}\text { Câmara } \\
\text { Municipal de } \\
\text { São Paulo }\end{array}$ & $\begin{array}{l}\text { Pronunciamen } \\
\text { to }\end{array}$ & & & $\begin{array}{l}\text { Sobre a escolha da } \\
\text { cidade para sediar } \\
\text { a Macabíada. }\end{array}$ \\
\hline
\end{tabular}




\begin{tabular}{|c|c|c|c|c|c|}
\hline $\begin{array}{l}12 \text { de } \\
\text { novembr } \\
\text { o de } \\
1964\end{array}$ & $\begin{array}{l}\text { Assembleia } \\
\text { Legislativa } \\
\text { de São } \\
\text { Paulo } \\
\end{array}$ & $\begin{array}{l}\text { Pronunciamen } \\
\text { to }\end{array}$ & Discussão & & \begin{tabular}{|l} 
Deputado José \\
Felício Castellano \\
discute sobre o \\
orçamento do \\
DEFE, que em 64 \\
foi de \\
$311.542 .600 .000,0$ \\
0, e em 1965 seria \\
de $494.166,00,0$ \\
que os deputados \\
consideraram \\
insuficiente.
\end{tabular} \\
\hline $\begin{array}{l}12 \text { de } \\
\text { novembr } \\
\text { o de } \\
1964\end{array}$ & $\begin{array}{l}\text { Assembleia } \\
\text { Legislativa } \\
\text { de São } \\
\text { Paulo } \\
\end{array}$ & $\begin{array}{l}\text { Pronunciamen } \\
\text { to }\end{array}$ & Parabenização & & $\begin{array}{l}\text { Parabenizam a } \\
\text { Gazeta Esportiva, } \\
\text { na pessoa de seu } \\
\text { diretor, Carlos Joel } \\
\text { Nelli, pela } \\
\text { realização da 40ำ } \\
\text { corrida de São } \\
\text { Silvestre. }\end{array}$ \\
\hline $\begin{array}{l}20 \text { de } \\
\text { novembr } \\
\text { o de } \\
1964\end{array}$ & $\begin{array}{l}\text { Assembleia } \\
\text { Legislativa } \\
\text { de São } \\
\text { Paulo } \\
\end{array}$ & Projeto de Lei & Parecer & $3919 / 64$ & $\begin{array}{l}\text { Parecer favorável } \\
\text { ao projeto de lei } \\
1317 \text { de } 51, \text { que } \\
\text { tratava do } \\
\text { afastamento de } \\
\text { servidores públicos } \\
\text { desportistas para } \\
\text { competições } \\
\text { oficiais, e que o } \\
\text { tempo de } \\
\text { afastamento } \\
\text { contasse para a } \\
\text { aposentadoria. }\end{array}$ \\
\hline \begin{tabular}{|l|}
24 de \\
novembr \\
o de \\
1964 \\
\end{tabular} & & $\begin{array}{l}\text { sociedade } \\
\text { civil mista }\end{array}$ & & & $\begin{array}{l}\text { Criação do Grêmio } \\
\text { esportivo Batalhão } \\
\text { Tobias Aguiar. }\end{array}$ \\
\hline $\begin{array}{l}8 \text { de } \\
\text { dezembr } \\
\text { o de } \\
1964\end{array}$ & $\begin{array}{l}\text { Governo do } \\
\text { Estado de } \\
\text { São Paulo }\end{array}$ & Ato executivo & Demanda da Alesp & & $\begin{array}{l}\text { Criação do centro } \\
\text { de recreação e } \\
\text { esportes, } \\
\text { submetido ao } \\
\text { DEFE, em } \\
\text { Itapetininga. } \\
\text { Validação de } \\
\text { projeto de lei } s / n \text {. }\end{array}$ \\
\hline $\begin{array}{l}10 \text { de } \\
\text { dezembr } \\
\text { o de } \\
1964\end{array}$ & $\begin{array}{l}\text { Governo do } \\
\text { Estado de } \\
\text { São Paulo }\end{array}$ & Ato executivo & Demanda da Alesp & & $\begin{array}{l}\text { Criação do centro } \\
\text { de recreação e } \\
\text { esportes, } \\
\text { submetido ao } \\
\text { DEFE, em Santa } \\
\text { Cruz do Rio Pardo. } \\
\text { Validação de } \\
\text { projeto de lei } \\
\text { 1590/64. }\end{array}$ \\
\hline $\begin{array}{l}11 \text { de } \\
\text { dezembr } \\
\text { o de } \\
1964\end{array}$ & $\begin{array}{l}\text { Governo do } \\
\text { Estado de } \\
\text { São Paulo }\end{array}$ & Ato executivo & Demanda da Alesp & & $\begin{array}{l}\text { Criação do centro } \\
\text { de recreação e } \\
\text { esportes, } \\
\text { submetido ao } \\
\text { DEFE, em } \\
\text { Itapetininga. } \\
\end{array}$ \\
\hline
\end{tabular}




\begin{tabular}{|c|c|c|c|c|c|}
\hline & & & & & $\begin{array}{l}\text { Validação de } \\
\text { projeto de lei s/n. }\end{array}$ \\
\hline $\begin{array}{l}22 \text { de } \\
\text { dezembr } \\
\text { o de } \\
1964 \\
\end{array}$ & $\begin{array}{l}\text { Câmara } \\
\text { Municipal de } \\
\text { São Paulo } \\
\end{array}$ & $\begin{array}{l}\text { Pronunciamen } \\
\text { to }\end{array}$ & Homenagem & & $\begin{array}{l}\text { Homenagem à } \\
\text { desportista Maria } \\
\text { Esther Bueno. }\end{array}$ \\
\hline $\begin{array}{l}13 \text { de } \\
\text { janeiro } \\
\text { de } 1965\end{array}$ & $\begin{array}{l}\text { Governo do } \\
\text { Estado de } \\
\text { São Paulo }\end{array}$ & Ato executivo & Veto & $\begin{array}{l}\text { projeto de lei } 172 \\
\text { de } 63\end{array}$ & $\begin{array}{l}\text { Adhemar de Barros } \\
\text { veta totalmente o } \\
\text { projeto de lei } 172 \\
\text { de } 1963 \text { que } \\
\text { demandava a } \\
\text { construção de } \\
\text { parque } \\
\text { futebolístico } \\
\text { estadual que } \\
\text { previa a } \\
\text { construção de } \\
\text { quinhentos campos } \\
\text { e cinco postos de } \\
\text { assistência } \\
\text { Médica. }\end{array}$ \\
\hline $\begin{array}{l}16 \text { de } \\
\text { janeiro } \\
\text { de } 1965\end{array}$ & $\begin{array}{l}\text { Governo do } \\
\text { Estado de } \\
\text { São Paulo } \\
\end{array}$ & Ato executivo & Veto & $\begin{array}{l}\text { projeto de lei } \\
693 / 63\end{array}$ & $\begin{array}{l}\text { Adhemar de Barros } \\
\text { veta totalmente o } \\
\text { projeto de lei } 693 \\
\text { de } 1963 \text { que se } \\
\text { referia à criação de } \\
\text { estádios distritais } \\
\text { nos bairros de } \\
\text { Itaim Bibi, Vila } \\
\text { Matilde, Vila } \\
\text { Califórnia e } \\
\text { Itaquera. } \\
\end{array}$ \\
\hline $\begin{array}{l}16 \text { de } \\
\text { março } \\
\text { de } 1965\end{array}$ & $\begin{array}{l}\text { Governo do } \\
\text { Estado de } \\
\text { São Paulo }\end{array}$ & $\begin{array}{l}\text { Pronunciamen } \\
\text { to }\end{array}$ & $\begin{array}{l}\text { Prestação de } \\
\text { contas }\end{array}$ & & $\begin{array}{l}\text { Secretaria de } \\
\text { Governo presta } \\
\text { contas de suas } \\
\text { ações no esporte. } \\
\text { Cita o complexo do } \\
\text { lbirapuera e o } \\
\text { Centro Olímpico. } \\
\end{array}$ \\
\hline $\begin{array}{l}16 \text { de } \\
\text { março } \\
\text { de } 1965\end{array}$ & $\begin{array}{l}\text { Governo do } \\
\text { Estado de } \\
\text { São Paulo } \\
\end{array}$ & Ato Executivo & Publicidade & & \begin{tabular}{|l|} 
Finalização do \\
complexo esportivo \\
do Ibirapuera e \\
novas instalações \\
no interior para \\
recreação infantil.
\end{tabular} \\
\hline $\begin{array}{l}17 \text { de } \\
\text { março } \\
\text { de } 1965\end{array}$ & $\begin{array}{l}\text { Governo do } \\
\text { Estado de } \\
\text { São Paulo } \\
\end{array}$ & Ato executivo & Portaria & 265 & $\begin{array}{l}\text { Alteração do } \\
\text { regulamento dos } \\
\text { Jogos Abertos do } \\
\text { Interior. }\end{array}$ \\
\hline $\begin{array}{l}17 \text { de } \\
\text { março } \\
\text { de } 1965\end{array}$ & $\begin{array}{l}\text { Assembleia } \\
\text { Legislativa } \\
\text { de São } \\
\text { Paulo } \\
\end{array}$ & $\begin{array}{l}\text { Pronunciamen } \\
\text { to }\end{array}$ & Projeto de lei & $19 / 65$ & $\begin{array}{l}\text { Prevê a criação de } \\
\text { centro de } \\
\text { recreação e } \\
\text { esportes em } \\
\text { Jundiaí. }\end{array}$ \\
\hline $\begin{array}{l}23 \text { de } \\
\text { março } \\
\text { de } 1965\end{array}$ & $\begin{array}{l}\text { Câmara } \\
\text { Municipal de } \\
\text { São Paulo } \\
\end{array}$ & $\begin{array}{l}\text { Pronunciamen } \\
\text { to }\end{array}$ & Homenagem & título de cidadão & $\begin{array}{l}\text { Câmara Municipal } \\
\text { de São Paulo } \\
\text { concede título de } \\
\text { cidadão ao Major }\end{array}$ \\
\hline
\end{tabular}




\begin{tabular}{|c|c|c|c|c|c|}
\hline & & & & & $\begin{array}{l}\text { Sylvio Magalhães } \\
\text { Padilha, diretor do } \\
\text { DEFE. }\end{array}$ \\
\hline $\begin{array}{l}23 \text { de } \\
\text { abril de } \\
1965\end{array}$ & $\begin{array}{l}\text { Governo do } \\
\text { Estado de } \\
\text { São Paulo }\end{array}$ & Ato executivo & & afastamento & $\begin{array}{l}\text { Afastamento } \\
\text { concedido a } \\
\text { funcionário do } \\
\text { DEFE para } \\
\text { participação no } \\
\text { Torneio } \\
\text { Bandeirantes em } \\
\text { Caçapava. }\end{array}$ \\
\hline $\begin{array}{l}24 \text { de } \\
\text { abril de } \\
1965\end{array}$ & $\begin{array}{l}\text { Assembleia } \\
\text { Legislativa } \\
\text { de São } \\
\text { Paulo }\end{array}$ & Projeto de Lei & Parecer & $1317 / 64$ & $\begin{array}{l}\text { Parecer favorável } \\
\text { ao projeto de lei } \\
\text { que prevê contar } \\
\text { como tempo de } \\
\text { serviço o período } \\
\text { em que o } \\
\text { funcionário público } \\
\text { estiver afastado } \\
\text { para participar de } \\
\text { competição } \\
\text { esportiva de } \\
\text { entidades oficiais } \\
\text { como atleta, } \\
\text { dirigente ou } \\
\text { preparador físico. }\end{array}$ \\
\hline $\begin{array}{l}06 \text { de } \\
\text { maio de } \\
1965\end{array}$ & $\begin{array}{l}\text { Assembleia } \\
\text { Legislativa } \\
\text { de São } \\
\text { Paulo }\end{array}$ & Projeto de Lei & Indicação & & $\begin{array}{l}\text { Prevê aumento do } \\
\text { subsídio dado pelo } \\
\text { Governo para a } \\
\text { Gazeta Esportiva. }\end{array}$ \\
\hline $\begin{array}{l}06 \text { de } \\
\text { maio de } \\
1965\end{array}$ & $\begin{array}{l}\text { Assembleia } \\
\text { Legislativa } \\
\text { de São } \\
\text { Paulo }\end{array}$ & $\begin{array}{l}\text { Sociedade } \\
\text { civil }\end{array}$ & Pedido & & $\begin{array}{l}\text { Estudantes da } \\
\text { Faculdade de } \\
\text { Direito de Bauru } \\
\text { recorrem à } \\
\text { Assembleia para } \\
\text { impedir que o } \\
\text { Ministério da } \\
\text { Educação } \\
\text { transformasse o } \\
\text { ginásio Alfredo } \\
\text { Colombo em } \\
\text { oficina de jornal. }\end{array}$ \\
\hline $\begin{array}{l}12 \text { de } \\
\text { maio de } \\
1965\end{array}$ & $\begin{array}{l}\text { Assembleia } \\
\text { Legislativa } \\
\text { de São } \\
\text { Paulo }\end{array}$ & $\begin{array}{l}\text { Pronunciamen } \\
\text { to }\end{array}$ & Ao Executivo & & $\begin{array}{l}\text { Deputado João } \\
\text { Batista Botelho } \\
\text { critica o } \\
\text { Governador por } \\
\text { fechar o ginásio de } \\
\text { Valparaíso e a } \\
\text { perseguição a } \\
\text { funcionários } \\
\text { públicos contrários } \\
\text { ao governo. O } \\
\text { deputado Walter } \\
\text { Arruda sai em } \\
\text { defesa do } \\
\text { governador citando } \\
\text { projetos de lei que } \\
\text { foram aprovados } \\
\text { mesmo sendo }\end{array}$ \\
\hline
\end{tabular}




\begin{tabular}{|c|c|c|c|c|}
\hline & & & & $\begin{array}{l}\text { oriundos da } \\
\text { oposição. }\end{array}$ \\
\hline $\begin{array}{l}12 \text { de } \\
\text { maio de } \\
1965\end{array}$ & $\begin{array}{l}\text { Assembleia } \\
\text { Legislativa } \\
\text { de São } \\
\text { Paulo } \\
\end{array}$ & Projeto de Lei & Parecer & $\begin{array}{l}\text { Parecer favorável } \\
\text { ao projeto de lei } 18 \\
\text { de } 65 \text { que visa a } \\
\text { criação do ginásio } \\
\text { de Jundiaí. Autoria } \\
\text { do deputado Omair } \\
\text { Zomignani. }\end{array}$ \\
\hline $\begin{array}{l}14 \text { de } \\
\text { maio de } \\
1965\end{array}$ & $\begin{array}{l}\text { Assembleia } \\
\text { Legislativa } \\
\text { de São } \\
\text { Paulo } \\
\end{array}$ & $\begin{array}{l}\text { Pronunciamen } \\
\text { to }\end{array}$ & Nota e Pesar & $\begin{array}{l}\text { Nota de pesar pelo } \\
\text { falecimento de } \\
\text { Mario Ricca, diretor } \\
\text { da Federação } \\
\text { Paulista de } \\
\text { Ciclismo. }\end{array}$ \\
\hline $\begin{array}{l}22 \text { de } \\
\text { maio de } \\
1965\end{array}$ & $\begin{array}{l}\text { Governo do } \\
\text { Estado de } \\
\text { São Paulo }\end{array}$ & $\begin{array}{l}\text { Pronunciamen } \\
\text { to }\end{array}$ & $\begin{array}{l}\text { prestação de } \\
\text { contas }\end{array}$ & $\begin{array}{l}\text { Publicização do } \\
\text { evento promovido } \\
\text { pelo governador } \\
\text { Adhemar de Barros } \\
\text { com os dirigentes } \\
\text { esportivos de } 35 \\
\text { federações } \\
\text { esportivas } \\
\text { anunciando } \\
\text { auxílios e } \\
\text { subvenções às } \\
\text { entidades. }\end{array}$ \\
\hline $\begin{array}{l}26 \text { de } \\
\text { maio de } \\
1965\end{array}$ & $\begin{array}{l}\text { Assembleia } \\
\text { Legislativa } \\
\text { de São } \\
\text { Paulo } \\
\end{array}$ & $\begin{array}{l}\text { Pronunciamen } \\
\text { to }\end{array}$ & Discussão & $\begin{array}{l}\text { Debate no plenário } \\
\text { sobre a construção } \\
\text { de ginásio de } \\
\text { esportes em } \\
\text { Campos do } \\
\text { Jordão. }\end{array}$ \\
\hline $\begin{array}{l}27 \text { de } \\
\text { maio de } \\
1965\end{array}$ & $\begin{array}{l}\text { Assembleia } \\
\text { Legislativa } \\
\text { de São } \\
\text { Paulo } \\
\end{array}$ & $\begin{array}{l}\text { Pronunciamen } \\
\text { to }\end{array}$ & Discussão & $\begin{array}{l}\text { Debate sobre a } \\
\text { destinação das } \\
\text { emendas } \\
\text { parlamentares a } \\
\text { entidades } \\
\text { religiosas e } \\
\text { esportivas. } \\
\text { Deputado } \\
\text { Scadamanche se } \\
\text { põe a favor e usa o } \\
\text { Pelé como } \\
\text { exemplo. Deputado } \\
\text { Botelho se coloca } \\
\text { contra falando } \\
\text { sobre a podridão } \\
\text { no futebol. }\end{array}$ \\
\hline $\begin{array}{l}27 \text { de } \\
\text { maio de } \\
1965\end{array}$ & $\begin{array}{l}\text { Assembleia } \\
\text { Legislativa } \\
\text { de São } \\
\text { Paulo } \\
\end{array}$ & $\begin{array}{l}\text { Pronunciamen } \\
\text { to }\end{array}$ & & $\begin{array}{l}\text { Deputado Lino } \\
\text { José Saglietti } \\
\text { discorre sobre a } \\
\text { reunião do } \\
\text { governador com os } \\
\text { dirigentes } \\
\text { esportivos na }\end{array}$ \\
\hline
\end{tabular}




\begin{tabular}{|c|c|c|c|c|c|}
\hline & & & & & $\begin{array}{l}\text { reunião de } 22 \text { de } \\
\text { maio. }\end{array}$ \\
\hline $\begin{array}{l}2 \text { de } \\
\text { junho de } \\
1965\end{array}$ & $\begin{array}{l}\text { Assembleia } \\
\text { Legislativa } \\
\text { de São } \\
\text { Paulo } \\
\end{array}$ & Ato legislativo & Mudança de nome & & $\begin{array}{l}\text { Mudança do nome } \\
\text { do Ginásio do } \\
\text { lbirapuera para } \\
\text { Ginásio estadual } \\
\text { de Esportes Fabio } \\
\text { da Silva Prado. } \\
\end{array}$ \\
\hline $\begin{array}{l}04 \text { de } \\
\text { junho de } \\
1965\end{array}$ & $\begin{array}{l}\text { Sociedade } \\
\text { Civil/Prefeitu } \\
\text { ra de São } \\
\text { Paulo }\end{array}$ & & Pedido & & $\begin{array}{l}\text { Presidente da } \\
\text { Federação Paulista } \\
\text { de Futebol pede ao } \\
\text { Prefeito } \\
\text { autorização para } \\
\text { aumentar o valor } \\
\text { dos ingressos } \\
\text { cobrados no } \\
\text { Pacaembu. } \\
\text { Vereador } \\
\text { Francisco de } \\
\text { Moraes se opõe e } \\
\text { diz que fará projeto } \\
\text { de lei que estipula } \\
\text { um teto ao valor } \\
\text { dos ingressos, } \\
\text { além de criticar a } \\
\text { Federacão. }\end{array}$ \\
\hline $\begin{array}{l}09 \text { de } \\
\text { junho } \\
1965\end{array}$ & $\begin{array}{l}\text { Assembleia } \\
\text { Legislativa } \\
\text { de São } \\
\text { Paulo }\end{array}$ & Projeto de Lei & Parecer & $1286 / 65$ & $\begin{array}{l}\text { Parecer favorável } \\
\text { ao projeto de Lei } \\
369 \text { de } 65, \text { do } \\
\text { Deputado Alfredo } \\
\text { Ignácio que } \\
\text { demandava a } \\
\text { criação de centro } \\
\text { esportivo na Água } \\
\text { Fria. }\end{array}$ \\
\hline $\begin{array}{l}09 \text { de } \\
\text { junho } \\
1965\end{array}$ & \begin{tabular}{|l} 
Câmara \\
municipal de \\
São Paulo \\
\end{tabular} & $\begin{array}{l}\text { Pronunciamen } \\
\text { to }\end{array}$ & Voto de Júbilo & 226 & $\begin{array}{l}\text { Do Vereador Alex } \\
\text { Freu Netto pela } \\
\text { reeleição do Dr. } \\
\text { Wadih Helu, pela } \\
\text { reeleição para a } \\
\text { presidência do } \\
\text { Esporte Clube } \\
\text { Corinthians } \\
\text { Paulista. } \\
\end{array}$ \\
\hline $\begin{array}{l}10 \text { de } \\
\text { junho de } \\
1965\end{array}$ & $\begin{array}{l}\text { Assembleia } \\
\text { Legislativa } \\
\text { de São } \\
\text { Paulo }\end{array}$ & Projeto de Lei & Apresentação & $623 / 65$ & $\begin{array}{l}\text { Apresentação de } \\
\text { projeto de lei que } \\
\text { torna obrigatório } \\
\text { haver local de } \\
\text { prática esportiva } \\
\text { em } \\
\text { estabelecimentos } \\
\text { públicos de ensino. }\end{array}$ \\
\hline $\begin{array}{l}10 \text { de } \\
\text { junho de } \\
1965\end{array}$ & $\begin{array}{l}\text { Câmara } \\
\text { municipal de } \\
\text { São Paulo }\end{array}$ & Ato legislativo & $\begin{array}{l}\text { Inclusão em } \\
\text { Comissão }\end{array}$ & & $\begin{array}{l}\text { Inclusão do } \\
\text { vereador Alex } \\
\text { Pereira Netto na } \\
\text { Comissão } \\
\text { Municipal de } \\
\text { Esportes. } \\
\end{array}$ \\
\hline
\end{tabular}




\begin{tabular}{|c|c|c|c|c|c|}
\hline $\begin{array}{l}15 \text { de } \\
\text { junho de } \\
1965\end{array}$ & $\begin{array}{l}\text { Assembleia } \\
\text { Legislativa } \\
\text { de São } \\
\text { Paulo }\end{array}$ & $\begin{array}{l}\text { Pronunciamen } \\
\text { to }\end{array}$ & Moção Honrosa & & $\begin{array}{l}\text { Moção honrosa à } \\
\text { Confederação } \\
\text { Brasileira de } \\
\text { Esportes pela } \\
\text { disputa do } \\
\text { Campeonato Sul- } \\
\text { Americano de } \\
\text { Atletismo no } \\
\text { Estado da } \\
\text { Guanabara. }\end{array}$ \\
\hline $\begin{array}{l}19 \text { de } \\
\text { junho de } \\
1965\end{array}$ & $\begin{array}{l}\text { Governo do } \\
\text { Estado de } \\
\text { São Paulo }\end{array}$ & Ato executivo & $\begin{array}{l}\text { Ajuste } \\
\text { Orçamentário }\end{array}$ & int. 65 & $\begin{array}{l}\text { Departamento } \\
\text { Público de Obras } \\
\text { ajusta o valor para } \\
\text { a construção das } \\
33 \text { quadras com a } \\
\text { empresa } \\
\text { Albuquerque e } \\
\text { Takaoka. }\end{array}$ \\
\hline $\begin{array}{l}19 \text { de } \\
\text { junho de } \\
1965\end{array}$ & $\begin{array}{l}\text { Governo do } \\
\text { Estado de } \\
\text { São Paulo }\end{array}$ & Ato executivo & $\begin{array}{l}\text { Ajuste } \\
\text { Orçamentário }\end{array}$ & int. 64 & $\begin{array}{l}\text { Departamento } \\
\text { Público de Obras } \\
\text { ajusta o valor para } \\
\text { a construção das } \\
48 \text { quadras com a } \\
\text { empresa } \\
\text { Albuquerque e } \\
\text { Takaoka. }\end{array}$ \\
\hline $\begin{array}{l}21 \text { de } \\
\text { junho de } \\
1965\end{array}$ & $\begin{array}{l}\text { Assembleia } \\
\text { Legislativa } \\
\text { de São } \\
\text { Paulo } \\
\end{array}$ & Projeto de Lei & Apresentação & & $\begin{array}{l}\text { Projeto de lei para } \\
\text { a criação de } \\
\text { ginásio de esportes } \\
\text { em Campinas. }\end{array}$ \\
\hline $\begin{array}{l}21 \text { de } \\
\text { junho de } \\
1965\end{array}$ & $\begin{array}{l}\text { Assembleia } \\
\text { Legislativa } \\
\text { de São } \\
\text { Paulo }\end{array}$ & Projeto de Lei & Apresentação & $768-65$ & $\begin{array}{l}\text { Propõe a criação } \\
\text { de centro de } \\
\text { esportes em } \\
\text { Valinhos, Paulínia, } \\
\text { Vinhedo, Pedreira } \\
\text { e Santa Barbada } \\
\text { D'Oeste. }\end{array}$ \\
\hline $\begin{array}{l}22 \text { de } \\
\text { junho de } \\
1965\end{array}$ & $\begin{array}{l}\text { Governo do } \\
\text { Estado de } \\
\text { São Paulo }\end{array}$ & Ato Executivo & $\begin{array}{l}\text { prestação de } \\
\text { contas }\end{array}$ & & $\begin{array}{l}\text { Anúncio no DO, na } \\
\text { forma de notícia, } \\
\text { das } 102 \text { quadras } \\
\text { (Albuquerque e } \\
\text { Takaoka) } \\
\text { autorizadas pelo } \\
\text { governador } \\
\text { Adhemar de } \\
\text { Barros. }\end{array}$ \\
\hline \begin{tabular}{|l}
23 de \\
junho de \\
1965
\end{tabular} & $\begin{array}{l}\text { Governo do } \\
\text { Estado de } \\
\text { São Paulo }\end{array}$ & Ato Executivo & Veto & PL1317/64 & $\begin{array}{l}\text { Veto ao projeto de } \\
\text { lei que visava } \\
\text { contar tempo de } \\
\text { serviço para } \\
\text { servidores que se } \\
\text { afastarem para } \\
\text { competições } \\
\text { esportivas, salvo } \\
\text { oficiais. }\end{array}$ \\
\hline \begin{tabular}{|l}
23 de \\
junho de \\
1965
\end{tabular} & $\begin{array}{l}\text { Assembleia } \\
\text { Legislativa } \\
\text { de São } \\
\text { Paulo } \\
\end{array}$ & Projeto de Lei & Apresentação & & \begin{tabular}{|l} 
Apresentada a \\
Assembleia \\
Legislativa projeto \\
de lei que criava o \\
FADA, Fundo de
\end{tabular} \\
\hline
\end{tabular}




\begin{tabular}{|c|c|c|c|c|c|}
\hline & & & & & $\begin{array}{l}\text { Apoio ao Esporte } \\
\text { Amador, ligado ao } \\
\text { DEFE. }\end{array}$ \\
\hline $\begin{array}{l}23 \text { de } \\
\text { junho de } \\
1965\end{array}$ & $\begin{array}{l}\text { Assembleia } \\
\text { Legislativa } \\
\text { de São } \\
\text { Paulo }\end{array}$ & Emendas & & & $\begin{array}{l}\text { Lista de apoio a } \\
\text { entidades } \\
\text { desportivas. }\end{array}$ \\
\hline $\begin{array}{l}24 \text { de } \\
\text { junho de } \\
1965\end{array}$ & $\begin{array}{l}\text { Assembleia } \\
\text { Legislativa } \\
\text { de São } \\
\text { Paulo }\end{array}$ & Projeto de Lei & Apresentação & 791/65 & $\begin{array}{l}\text { Prevê criação de } \\
\text { centro esportivo } \\
\text { em Bragança } \\
\text { Paulista. }\end{array}$ \\
\hline $\begin{array}{l}24 \text { de } \\
\text { junho de } \\
1965\end{array}$ & $\begin{array}{l}\text { Assembleia } \\
\text { Legislativa } \\
\text { de São } \\
\text { Paulo } \\
\end{array}$ & Projeto de Lei & Apresentação & $766 / 65$ & $\begin{array}{l}\text { Prevê a criação de } \\
\text { centro esportivo } \\
\text { em Campinas. }\end{array}$ \\
\hline $\begin{array}{l}02 \text { de } \\
\text { junho de } \\
1965\end{array}$ & $\begin{array}{l}\text { Assembleia } \\
\text { Legislativa } \\
\text { de São } \\
\text { Paulo } \\
\end{array}$ & $\begin{array}{l}\text { Pronunciamen } \\
\text { to }\end{array}$ & defesa & & $\begin{array}{l}\text { Fala do deputado } \\
\text { Salgado Casillom } \\
\text { em defesa do } \\
\text { Jaraguá de } \\
\text { Piracicaba que } \\
\text { teve problemas } \\
\text { com a prestação } \\
\text { de contas de } \\
\text { emenda } \\
\text { parlamentar junto } \\
\text { ao TCM. } \\
\end{array}$ \\
\hline $\begin{array}{l}02 \text { de } \\
\text { junho de } \\
1965\end{array}$ & $\begin{array}{l}\text { Câmara } \\
\text { municipal de } \\
\text { São Paulo }\end{array}$ & $\begin{array}{l}\text { Pronunciamen } \\
\text { to }\end{array}$ & & & $\begin{array}{l}\text { Fala do vereador } \\
\text { Monteiro Carvalho } \\
\text { contra a pressão } \\
\text { da Federação } \\
\text { Paulista de Futebol } \\
\text { para autorização } \\
\text { da Prefeitura } \\
\text { aumentar o valor } \\
\text { dos ingressos no } \\
\text { Pacaembu. }\end{array}$ \\
\hline \begin{tabular}{|l|}
02 de \\
junho de \\
1965 \\
\end{tabular} & $\begin{array}{l}\text { Sociedade } \\
\text { Civil }\end{array}$ & Fundação & & & $\begin{array}{l}\text { Criação de Clube } \\
\text { de Hipismo. }\end{array}$ \\
\hline $\begin{array}{l}13 \text { de } \\
\text { julho de } \\
1965\end{array}$ & $\begin{array}{l}\text { Governo do } \\
\text { Estado de } \\
\text { São Paulo } \\
\end{array}$ & ato Executivo & $\begin{array}{l}\text { Subvenção } \\
\text { Orçamentária }\end{array}$ & & $\begin{array}{l}\text { Ata sobre } \\
\text { subvenção para a } \\
\text { construção das } 33 \\
\text { quadras com a } \\
\text { Albuquerque e } \\
\text { Takaoka } \\
\end{array}$ \\
\hline $\begin{array}{l}16 \text { de } \\
\text { junho de } \\
1965\end{array}$ & $\begin{array}{l}\text { Governo do } \\
\text { Estado de } \\
\text { São Paulo }\end{array}$ & Ato Executivo & Decreto & $45012-65$ & $\begin{array}{l}\text { Decreto que } \\
\text { regulamenta o } \\
\text { funcionamento do } \\
\text { DEFE. }\end{array}$ \\
\hline $\begin{array}{l}18 \text { de } \\
\text { julho de } \\
1965\end{array}$ & $\begin{array}{l}\text { Assembleia } \\
\text { Legislativa } \\
\text { de São } \\
\text { Paulo }\end{array}$ & $\begin{array}{l}\text { Pronunciamen } \\
\text { to }\end{array}$ & Repudio & & $\begin{array}{l}\text { Fala do deputado } \\
\text { Paulo Planet } \\
\text { Buarque em } \\
\text { repúdio à } \\
\text { Federação Paulista } \\
\text { de Futebol e dos } \\
\text { times por proibirem } \\
\text { o televisionamento } \\
\text { das partidas. }\end{array}$ \\
\hline
\end{tabular}




\begin{tabular}{|c|c|c|c|c|c|}
\hline $\begin{array}{l}06 \text { de } \\
\text { agosto } \\
\text { de } 1965\end{array}$ & $\begin{array}{l}\text { Assembleia } \\
\text { Legislativa } \\
\text { de São } \\
\text { Paulo } \\
\end{array}$ & Projeto de Lei & Apresentação & $923 / 65$ & $\begin{array}{l}\text { Projeto que prevê } \\
\text { subvenção } \\
\text { orçamentária para } \\
\text { a cidade que for } \\
\text { sede dos Jogos } \\
\text { Abertos do Interior. }\end{array}$ \\
\hline $\begin{array}{l}07 \text { de } \\
\text { agosto } \\
\text { de } 1965\end{array}$ & $\begin{array}{l}\text { Assembleia } \\
\text { Legislativa } \\
\text { de São } \\
\text { Paulo } \\
\end{array}$ & Projeto de Lei & Parecer & $1802 / 65$ & $\begin{array}{l}\text { Parecer favorável } \\
\text { ao projeto de lei } \\
\text { que visa criar } \\
\text { Estádio Regional } \\
\text { em Marília. } \\
\end{array}$ \\
\hline $\begin{array}{l}07 \text { de } \\
\text { agosto } \\
\text { de } 1965\end{array}$ & $\begin{array}{l}\text { Assembleia } \\
\text { Legislativa } \\
\text { de São } \\
\text { Paulo } \\
\end{array}$ & $\begin{array}{l}\text { Pronunciamen } \\
\text { to }\end{array}$ & Discussão & & $\begin{array}{l}\text { Discussão na } \\
\text { Assembleia sobre } \\
\text { a atuação de } \\
\text { Adhemar de Barros } \\
\text { na "revolução", } \\
\text { sobre a ameaça } \\
\text { comunista. } \\
\end{array}$ \\
\hline $\begin{array}{l}11 \text { de } \\
\text { agosto } \\
\text { de } 1965\end{array}$ & $\begin{array}{l}\text { Governo do } \\
\text { Estado de } \\
\text { São Paulo }\end{array}$ & Ato Executivo & Autorização & & $\begin{array}{l}\text { Autorização do } \\
\text { Governador para } \\
\text { obras do DEFE na } \\
\text { Água Branca e na } \\
\text { praça de atletismo } \\
\text { do lbirapuera. }\end{array}$ \\
\hline $\begin{array}{l}21 \text { de } \\
\text { agosto } \\
\text { de } 1965\end{array}$ & $\begin{array}{l}\text { Assembleia } \\
\text { Legislativa } \\
\text { de São } \\
\text { Paulo } \\
\end{array}$ & $\begin{array}{l}\text { Estudo de } \\
\text { comissão }\end{array}$ & & $422 / 65$ & $\begin{array}{l}\text { Gabinete de } \\
\text { assistência técnica } \\
\text { da Alesp fala de } \\
\text { subvenções para o } \\
\text { esporte e para } \\
\text { entidades } \\
\text { esportivas. }\end{array}$ \\
\hline $\begin{array}{l}24 \text { de } \\
\text { agosto } \\
\text { de } 1965\end{array}$ & $\begin{array}{l}\text { Assembleia } \\
\text { Legislativa } \\
\text { de São } \\
\text { Paulo } \\
\end{array}$ & $\begin{array}{l}\text { Pronunciamen } \\
\text { to }\end{array}$ & Discussão & & $\begin{array}{l}\text { Debate sobre criar } \\
\text { grupos escoteiros } \\
\text { nos } \\
\text { estabelecimentos } \\
\text { de ensino, ao } \\
\text { exemplo da } \\
\text { juventude nazista } \\
\text { "favorável, mas....". }\end{array}$ \\
\hline $\begin{array}{l}20 \text { de } \\
\text { setembr } \\
\text { o de } \\
1965\end{array}$ & $\begin{array}{l}\text { Assembleia } \\
\text { Legislativa } \\
\text { de São } \\
\text { Paulo } \\
\end{array}$ & Projeto de Lei & Discussão & $1001 / 65$ & $\begin{array}{l}\text { Trata de auxílio } \\
\text { financeiro a } \\
\text { entidades } \\
\text { desportivas } \\
\text { amadoras. } \\
\end{array}$ \\
\hline $\begin{array}{l}24 \text { de } \\
\text { setembr } \\
\text { o de } \\
1965\end{array}$ & $\begin{array}{l}\text { Assembleia } \\
\text { Legislativa } \\
\text { de São } \\
\text { Paulo } \\
\end{array}$ & $\begin{array}{l}\text { Pronunciamen } \\
\text { to }\end{array}$ & Repúdio & & $\begin{array}{l}\text { Fala do deputado } \\
\text { Paulo Planet } \\
\text { Buarque contra a } \\
\text { diminuição das } \\
\text { aulas de educação } \\
\text { física nos } \\
\text { estabelecimentos } \\
\text { de ensino, de } 3 \\
\text { para } 1 .\end{array}$ \\
\hline $\begin{array}{l}05 \text { de } \\
\text { outubro } \\
\text { de } 1965\end{array}$ & $\begin{array}{l}\text { Assembleia } \\
\text { Legislativa } \\
\text { de São } \\
\text { Paulo } \\
\end{array}$ & $\begin{array}{l}\text { Pronunciamen } \\
\text { to }\end{array}$ & & & $\begin{array}{l}\text { Fala do deputado } \\
\text { José Maria Marin } \\
\text { de elogio ao } \\
\text { prefeito de São } \\
\text { Paulo por ter } \\
\text { concedido } \\
\text { aumento razoável }\end{array}$ \\
\hline
\end{tabular}




\begin{tabular}{|c|c|c|c|c|c|}
\hline & & & & & $\begin{array}{l}\text { à cobrança de } \\
\text { ingressos dos } \\
\text { estádios } \\
\text { municipais, e não o } \\
\text { valor pretendido } \\
\text { pela Federação } \\
\text { Paulista de } \\
\text { Futebol. } \\
\end{array}$ \\
\hline $\begin{array}{l}08 \text { de } \\
\text { outubro } \\
\text { de } 1965\end{array}$ & $\begin{array}{l}\text { Governo do } \\
\text { Estado de } \\
\text { São Paulo }\end{array}$ & Ato Executivo & $\begin{array}{l}\text { Informe da } \\
\text { Secretária de } \\
\text { Obras }\end{array}$ & & $\begin{array}{l}\text { Informe ao } \\
\text { governador do } \\
\text { resultado da } \\
\text { licitação feita para } \\
\text { as obras no } \\
\text { lbirapuera. }\end{array}$ \\
\hline $\begin{array}{l}10 \text { de } \\
\text { outubro } \\
\text { de } 1965 \\
\end{array}$ & $\begin{array}{l}\text { Câmara } \\
\text { municipal de } \\
\text { São Paulo } \\
\end{array}$ & $\begin{array}{l}\text { Pronunciamen } \\
\text { to }\end{array}$ & & & $\begin{array}{l}\text { Vereador Pereira } \\
\text { Barreto pede ajuda } \\
\text { da Prefeitura para } \\
\text { a realização das } 50 \\
\text { de interlagos, } \\
\text { realizada no } \\
\text { autódromo } \\
\text { municipal. } \\
\end{array}$ \\
\hline $\begin{array}{l}15 \text { de } \\
\text { outubro } \\
\text { de } 1965\end{array}$ & $\begin{array}{l}\text { Governo do } \\
\text { Estado de } \\
\text { São Paulo }\end{array}$ & Ato Executivo & Autorização & & $\begin{array}{l}\text { Autorização do } \\
\text { Governador para } \\
\text { construção de } \\
\text { conjunto esportivo } \\
\text { no lbirapuera e } \\
\text { reforma do ginásio. }\end{array}$ \\
\hline $\begin{array}{l}15 \text { de } \\
\text { outubro } \\
\text { de } 1965 \\
\end{array}$ & $\begin{array}{l}\text { Governo do } \\
\text { Estado de } \\
\text { São Paulo } \\
\end{array}$ & Ato Executivo & Autorização & & $\begin{array}{l}\text { Autorização do } \\
\text { Governador para } \\
\text { acréscimo de } 1 \\
\text { aula semanal de } \\
\text { educação física } \\
\text { nos } \\
\text { estabelecimentos } \\
\text { de ensino. }\end{array}$ \\
\hline $\begin{array}{l}22 \text { de } \\
\text { outubro } \\
\text { de } 1965\end{array}$ & $\begin{array}{l}\text { Assembleia } \\
\text { Legislativa } \\
\text { de São } \\
\text { Paulo } \\
\end{array}$ & emendas & destinação & $13 / 698.65$ & $\begin{array}{l}\text { Trata de emendas } \\
\text { ao orçamento } \\
\text { destinadas ao } \\
\text { DEFE e a } \\
\text { Confederação } \\
\text { Brasileira para a } \\
\text { Seleção } \\
\text { participante da } \\
\text { Copa. }\end{array}$ \\
\hline $\begin{array}{l}26 \text { de } \\
\text { outubro } \\
\text { de } 1965\end{array}$ & $\begin{array}{l}\text { Assembleia } \\
\text { Legislativa } \\
\text { de São } \\
\text { Paulo }\end{array}$ & Emendas & Liberação & & \begin{tabular}{|l|} 
Indicação e \\
emenda \\
parlamentar par ao \\
Mackenzie, para a \\
realização das \\
Olimpíadas \\
Universitárias.
\end{tabular} \\
\hline $\begin{array}{l}26 \text { de } \\
\text { outubro } \\
\text { de } 1965\end{array}$ & $\begin{array}{l}\text { Assembleia } \\
\text { Legislativa } \\
\text { de São } \\
\text { Paulo } \\
\end{array}$ & Emendas & Liberação & & $\begin{array}{l}\text { Emenda } \\
\text { parlamentar } \\
\text { destinada à } \\
\text { Federação Paulista } \\
\text { de Atletismo. } \\
\end{array}$ \\
\hline
\end{tabular}




\begin{tabular}{|c|c|c|c|c|c|}
\hline $\begin{array}{l}13 \text { de } \\
\text { novembr } \\
\text { o de } \\
1965 \\
\end{array}$ & $\begin{array}{l}\text { Assembleia } \\
\text { Legislativa } \\
\text { de São } \\
\text { Paulo } \\
\end{array}$ & $\begin{array}{l}\text { Pronunciamen } \\
\text { to }\end{array}$ & discussão & & $\begin{array}{l}\text { Discute-se no } \\
\text { plenário a } \\
\text { importância ou não } \\
\text { de verbas para o } \\
\text { esporte, visto que } \\
\text { nem sempre o } \\
\text { esporte precisa de } \\
\text { apoio público. }\end{array}$ \\
\hline $\begin{array}{l}20 \text { de } \\
\text { novembr } \\
\text { o de } \\
1965\end{array}$ & $\begin{array}{l}\text { Assembleia } \\
\text { Legislativa } \\
\text { de São } \\
\text { Paulo } \\
\end{array}$ & Projeto de Lei & Parecer & $374 / 65$ & $\begin{array}{l}\text { Parecer favorável } \\
\text { ao projeto de lei } \\
\text { que visa aumentar } \\
\text { o auxílio financeiro } \\
\text { dado à Gazeta } \\
\text { Esportiva } \\
\end{array}$ \\
\hline $\begin{array}{l}26 \text { de } \\
\text { novembr } \\
\text { o de } \\
1965\end{array}$ & & & & & \begin{tabular}{|l|} 
Visita da \\
delegação \\
esportiva da União \\
Soviética e Hungria \\
ao Estádio Paulo \\
Machado.
\end{tabular} \\
\hline $\begin{array}{l}11 \text { de } \\
\text { dezembr } \\
\text { o de } \\
1965\end{array}$ & $\begin{array}{l}\text { Assembleia } \\
\text { Legislativa } \\
\text { de São } \\
\text { Paulo }\end{array}$ & Projeto de Lei & Parecer & $3991 / 65$ & $\begin{array}{l}\text { Parecer favorável } \\
\text { ao projeto de lei } \\
1358 / 65, \text { que prevê } \\
\text { auxílio financeiro } \\
\text { anual aos times } \\
\text { filiados à } \\
\text { Federação Paulista } \\
\text { de Futebol que } \\
\text { chegarem a } \\
\text { primeira divisão e a } \\
\text { divisão especial. }\end{array}$ \\
\hline $\begin{array}{l}18 \text { de } \\
\text { dezembr } \\
\text { o de } \\
1965 \\
\end{array}$ & $\begin{array}{l}\text { Assembleia } \\
\text { Legislativa } \\
\text { de São } \\
\text { Paulo } \\
\end{array}$ & $\begin{array}{l}\text { Pronunciamen } \\
\text { to }\end{array}$ & Homenagem & & $\begin{array}{l}\text { Congratulações na } \\
\text { Assembleia para a } \\
\text { Gazeta Esportiva } \\
\text { pela realização da } \\
\text { corrida de São } \\
\text { Silvestre. } \\
\end{array}$ \\
\hline \begin{tabular}{|l|}
18 de \\
dezembr \\
o de \\
1965
\end{tabular} & $\begin{array}{l}\text { Assembleia } \\
\text { Legislativa } \\
\text { de São } \\
\text { Paulo } \\
\end{array}$ & $\begin{array}{l}\text { Pronunciamen } \\
\text { to }\end{array}$ & Discussão & & $\begin{array}{l}\text { Discussão sobre } \\
\text { projeto de lei que } \\
\text { concede verbas ao } \\
\text { esporte. }\end{array}$ \\
\hline \begin{tabular}{|l|}
18 de \\
dezembr \\
o de \\
1965 \\
\end{tabular} & $\begin{array}{l}\text { Assembleia } \\
\text { Legislativa } \\
\text { de São } \\
\text { Paulo } \\
\end{array}$ & Ato legislativo & & & $\begin{array}{l}\text { Integração de } \\
\text { Araçatuba na } \\
\text { Federação Paulista } \\
\text { de Futebol }\end{array}$ \\
\hline $\begin{array}{l}18 \text { de } \\
\text { dezembr } \\
\text { o de } \\
1965\end{array}$ & $\begin{array}{l}\text { Assembleia } \\
\text { Legislativa } \\
\text { de São } \\
\text { Paulo }\end{array}$ & Projeto de Lei & Discussão & & $\begin{array}{l}\text { Discussão sobre o } \\
\text { projeto } \\
\text { apresentado pelo } \\
\text { deputado Ciro } \\
\text { Albuquerque para } \\
\text { construção de } \\
\text { praças de esportes } \\
\text { no interior do } \\
\text { estado. }\end{array}$ \\
\hline $\begin{array}{l}21 \text { de } \\
\text { dezembr } \\
\text { o de } \\
1965\end{array}$ & $\begin{array}{l}\text { Assembleia } \\
\text { Legislativa } \\
\text { de São } \\
\text { Paulo } \\
\end{array}$ & $\begin{array}{l}\text { Pronunciamen } \\
\text { to }\end{array}$ & Discussão & & \begin{tabular}{|l|} 
Discussão na \\
Assembleia sobre \\
aumento de verba \\
para a Gazeta \\
Esportiva realizar a
\end{tabular} \\
\hline
\end{tabular}




\begin{tabular}{|c|c|c|c|c|c|}
\hline & & & & & $\begin{array}{l}\text { corrida de São } \\
\text { Silvestre. }\end{array}$ \\
\hline $\begin{array}{l}22 \text { de } \\
\text { dezembr } \\
\text { o de } \\
1965\end{array}$ & $\begin{array}{l}\text { Assembleia } \\
\text { Legislativa } \\
\text { de São } \\
\text { Paulo } \\
\end{array}$ & $\begin{array}{l}\text { Pronunciamen } \\
\text { to }\end{array}$ & & & $\begin{array}{l}\text { Ciro Albuquerque } \\
\text { discorre sobre } \\
\text { auxílio aos times } \\
\text { filiados à federação } \\
\text { paulista de futebol } \\
\text { que chegarem a } \\
\text { primeira divisão e } \\
\text { divisão especial. }\end{array}$ \\
\hline \begin{tabular}{|l|}
22 de \\
dezembr \\
o de \\
1965 \\
\end{tabular} & \begin{tabular}{|l} 
Assembleia \\
Legislativa \\
de São \\
Paulo \\
\end{tabular} & $\begin{array}{l}\text { Pronunciamen } \\
\text { to }\end{array}$ & & & $\begin{array}{l}\text { Discurso sobre a } \\
\text { São Silvestre. }\end{array}$ \\
\hline \begin{tabular}{|l|}
23 de \\
dezembr \\
o de \\
1965 \\
\end{tabular} & $\begin{array}{l}\text { Assembleia } \\
\text { Legislativa } \\
\text { de São } \\
\text { Paulo } \\
\end{array}$ & $\begin{array}{l}\text { Pronunciamen } \\
\text { to }\end{array}$ & Homenagem & & $\begin{array}{l}\text { Homenagem a Ary } \\
\text { Silvio - } \\
\text { comentarista } \\
\text { esportivo. }\end{array}$ \\
\hline \begin{tabular}{|l|}
23 de \\
dezembr \\
o de \\
1965 \\
\end{tabular} & \begin{tabular}{|l} 
Assembleia \\
Legislativa \\
de São \\
Paulo \\
\end{tabular} & $\begin{array}{l}\text { Pronunciamen } \\
\text { to }\end{array}$ & Discussão & & $\begin{array}{l}\text { Discurso sobre } \\
\text { obras no esporte. }\end{array}$ \\
\hline \begin{tabular}{|l|}
24 de \\
dezembr \\
o de \\
1965 \\
\end{tabular} & $\begin{array}{l}\text { Assembleia } \\
\text { Legislativa } \\
\text { de São } \\
\text { Paulo } \\
\end{array}$ & $\begin{array}{l}\begin{array}{l}\text { Pronunciamen } \\
\text { to }\end{array} \\
\end{array}$ & Discussão & & $\begin{array}{l}\text { Discussão sobre } \\
\text { criação de praça } \\
\text { de esportes em } \\
\text { ltapetininga. }\end{array}$ \\
\hline $\begin{array}{l}30 \text { de } \\
\text { dezembr } \\
\text { o de } \\
1965 \\
\end{array}$ & $\begin{array}{l}\text { Assembleia } \\
\text { Legislativa } \\
\text { de São } \\
\text { Paulo }\end{array}$ & Projeto de Lei & Parecer & $\begin{array}{l}\text { PL1602/65/4116/ } \\
65\end{array}$ & $\begin{array}{l}\text { Parecer favorável } \\
\text { ao PL que prevê a } \\
\text { criação de praça } \\
\text { de esportes em } \\
\text { Itapetininga. } \\
\end{array}$ \\
\hline & & & & & \\
\hline $\begin{array}{l}05 \text { de } \\
\text { janeiro } \\
\text { de } 1966\end{array}$ & $\begin{array}{l}\text { Assembleia } \\
\text { Legislativa } \\
\text { de São } \\
\text { Paulo }\end{array}$ & $\begin{array}{l}\text { Pronunciamen } \\
\text { to }\end{array}$ & Homenagem & & $\begin{array}{l}\text { Deputado Muzete } \\
\text { fala sobre a } \\
\text { realização dos } \\
\text { Jogos abertos do } \\
\text { Interior e enaltece } \\
\text { a figura do Major } \\
\text { Padilha. Fala-se de } \\
\text { verbas para } \\
\text { entidades } \\
\text { desportivas } \\
\text { indicadas pelo } \\
\text { governador. }\end{array}$ \\
\hline $\begin{array}{l}29 \text { de } \\
\text { janeiro } \\
\text { de } 1966\end{array}$ & $\begin{array}{l}\text { Governo do } \\
\text { Estado de } \\
\text { São Paulo }\end{array}$ & Ato Executivo & Portaria & DEFE & $\begin{array}{l}\text { Major Padilha } \\
\text { resolve alterar a } \\
\text { regulamentação do } \\
\text { Troféu Brasil. }\end{array}$ \\
\hline $\begin{array}{l}29 \text { de } \\
\text { março } \\
\text { de } 1966\end{array}$ & \begin{tabular}{|l} 
Assembleia \\
Legislativa \\
de São \\
Paulo \\
\end{tabular} & $\begin{array}{l}\text { Pronunciamen } \\
\text { to }\end{array}$ & Discussão & & $\begin{array}{l}\text { Discussão sobre } \\
\text { tributação dos } \\
\text { boliches. }\end{array}$ \\
\hline $\begin{array}{l}06 \text { de } \\
\text { abril de } \\
1966\end{array}$ & $\begin{array}{l}\text { Câmara } \\
\text { municipal de } \\
\text { São Paulo }\end{array}$ & $\begin{array}{l}\text { Pronunciamen } \\
\text { to }\end{array}$ & Ao Executivo & & \begin{tabular}{|l|} 
Vereador Jayme \\
Rodrigues fala do \\
abandono do \\
Clube esportivo da \\
Mooca. \\
\end{tabular} \\
\hline
\end{tabular}




\begin{tabular}{|c|c|c|c|c|}
\hline $\begin{array}{l}12 \text { de } \\
\text { maio de } \\
1966\end{array}$ & $\begin{array}{l}\text { Assembleia } \\
\text { Legislativa } \\
\text { de São } \\
\text { Paulo } \\
\end{array}$ & Projeto de Lei & Discussão & $\begin{array}{l}\text { Debate sobre a } \\
\text { criação do FADA - } \\
\text { Fundo de } \\
\text { Assistência ao } \\
\text { Desporto Amador. }\end{array}$ \\
\hline $\begin{array}{l}27 \text { de } \\
\text { maio de } \\
1966\end{array}$ & $\begin{array}{l}\text { Câmara } \\
\text { municipal de } \\
\text { São Paulo } \\
\end{array}$ & $\begin{array}{l}\text { Pronunciamen } \\
\text { to }\end{array}$ & Homenagem & \begin{tabular}{|l} 
Vereador José \\
Maria Marin \\
parabeniza prefeito \\
Faria Lima pela \\
construção de \\
Centro \\
Educacional e \\
Esportivo em \\
Santo Amaro. \\
\end{tabular} \\
\hline $\begin{array}{l}03 \text { de } \\
\text { junho de } \\
1966\end{array}$ & $\begin{array}{l}\text { Câmara } \\
\text { municipal de } \\
\text { São Paulo }\end{array}$ & $\begin{array}{l}\text { Pronunciamen } \\
\text { to }\end{array}$ & $\begin{array}{l}\text { Prestação de } \\
\text { Contas }\end{array}$ & $\begin{array}{l}\text { Monteiro Carvalho } \\
\text { fala da reunião que } \\
\text { ocorreu na } \\
\text { Secretaria de } \\
\text { Finanças com } \\
\text { mentores do } \\
\text { futebol profissional, } \\
\text { dirigentes de rádio } \\
\text { e tv e jornalistas. } \\
\text { Deixa claro que } \\
\text { não é contra os } \\
\text { incentivos ao } \\
\text { esporte amador, } \\
\text { mas cobra } \\
\text { regulamentação da } \\
\text { União. }\end{array}$ \\
\hline \begin{tabular}{|l|}
04 de \\
junho de \\
1966 \\
\end{tabular} & \begin{tabular}{|l|} 
Governo do \\
Estado de \\
São Paulo \\
\end{tabular} & Ato Executivo & & \begin{tabular}{|l|} 
Início das \\
Olímpiadas de \\
Americana. \\
\end{tabular} \\
\hline $\begin{array}{l}17 \text { de } \\
\text { junho de } \\
1966 \\
\end{array}$ & \begin{tabular}{|l} 
Assembleia \\
Legislativa \\
de São \\
Paulo \\
\end{tabular} & $\begin{array}{l}\text { Pronunciamen } \\
\text { to }\end{array}$ & nota de pesar & $\begin{array}{l}\text { Nota de pesar pela } \\
\text { morte do jornalista } \\
\text { Guimaga. }\end{array}$ \\
\hline \begin{tabular}{|l}
23 de \\
junho de \\
1966 \\
\end{tabular} & $\begin{array}{l}\text { Governo do } \\
\text { Estado de } \\
\text { São Paulo } \\
\end{array}$ & Ato Executivo & $\begin{array}{l}\text { Consulta ao } \\
\text { Legislativo }\end{array}$ & $\begin{array}{l}\text { Governador Laudo } \\
\text { Natel faz consulta } \\
\text { à Assembleia } \\
\text { sobre a } \\
\text { possibilidade de } \\
\text { comprar } \\
\text { videotapes da } \\
\text { Copa do Mundo. }\end{array}$ \\
\hline $\begin{array}{l}29 \text { de } \\
\text { junho de } \\
1966 \\
\end{array}$ & $\begin{array}{l}\text { Assembleia } \\
\text { Legislativa } \\
\text { de São } \\
\text { Paulo } \\
\end{array}$ & $\begin{array}{l}\begin{array}{l}\text { Pronunciamen } \\
\text { to }\end{array} \\
\end{array}$ & Discussão & $\begin{array}{l}\text { Deputado José } \\
\text { Lurtz Sabia critica } \\
\text { a compra de } \\
\text { videotapes da } \\
\text { Copa do Mundo, } \\
\text { alegando } \\
\text { sobretudo o alto } \\
\text { custo, } 1 \text { bilhão e } \\
\text { quinhentos mil } \\
\text { cruzeiros. } \\
\end{array}$ \\
\hline $\begin{array}{l}06 \text { de } \\
\text { agosto } \\
\text { de } 1966\end{array}$ & $\begin{array}{l}\text { Assembleia } \\
\text { Legislativa } \\
\text { de São } \\
\text { Paulo }\end{array}$ & $\begin{array}{l}\text { Pronunciamen } \\
\text { to }\end{array}$ & Discussão & $\begin{array}{l}\text { Deputado Paulo } \\
\text { Planet Buarque } \\
\text { fala favorável a } \\
\text { intenção do } \\
\text { governo de criar }\end{array}$ \\
\hline
\end{tabular}




\begin{tabular}{|c|c|c|c|c|c|}
\hline & & & & & $\begin{array}{l}\text { loteria estadual e } \\
\text { reverter os lucros } \\
\text { para as Santas } \\
\text { Casas de } \\
\text { misericórdia, } \\
\text { porém diz que } \\
\text { parte desse } \\
\text { recurso deveria ser } \\
\text { destinado também } \\
\text { para o esporte } \\
\text { amador. }\end{array}$ \\
\hline $\begin{array}{l}10 \text { de } \\
\text { agosto } \\
\text { de } 1966\end{array}$ & $\begin{array}{l}\text { Assembleia } \\
\text { Legislativa } \\
\text { de São } \\
\text { Paulo } \\
\end{array}$ & Projeto de Lei & Discussão & PL 219/64 & \begin{tabular}{|l|} 
De autoria do \\
deputado \\
Francisco Moraes \\
o PL sujeita os \\
clubes desportivos \\
profissionais ao ato \\
no 1159.36, Art. \\
500 e 217 da \\
legislação fiscal do \\
município de São \\
Paulo, cuja renda \\
seria destinada ao \\
incremento do \\
esporte amador. \\
\end{tabular} \\
\hline \begin{tabular}{|l|l}
11 de \\
agosto \\
de 1966
\end{tabular} & \begin{tabular}{|l|} 
Assembleia \\
Legislativa \\
de São \\
Paulo \\
\end{tabular} & Projeto de Lei & Discussão & PL 219/64 & $\begin{array}{l}\text { Primeira discussão } \\
\text { sobre o projeto. }\end{array}$ \\
\hline \begin{tabular}{|l}
12 de \\
agosto \\
de 1966
\end{tabular} & \begin{tabular}{|l|} 
Assembleia \\
Legislativa \\
de São \\
Paulo \\
\end{tabular} & Projeto de Lei & Discussão & PL 219/64 & $\begin{array}{l}\text { Primeira discussão } \\
\text { sobre o projeto. }\end{array}$ \\
\hline \begin{tabular}{|l}
13 de \\
agosto \\
de 1966
\end{tabular} & \begin{tabular}{|l|} 
Assembleia \\
Legislativa \\
de São \\
Paulo \\
\end{tabular} & Projeto de Lei & Discussão & PL 219/64 & $\begin{array}{l}\text { Primeira discussão } \\
\text { sobre o projeto. }\end{array}$ \\
\hline \begin{tabular}{|l}
17 de \\
agosto \\
de 1966
\end{tabular} & \begin{tabular}{|l|} 
Assembleia \\
Legislativa \\
de São \\
Paulo \\
\end{tabular} & Projeto de Lei & Discussão & PL 219/64 & $\begin{array}{l}\text { Aprovado PL } \\
219 / 64 \text { na primeira } \\
\text { discussão. }\end{array}$ \\
\hline $\begin{array}{l}19 \text { de } \\
\text { agosto } \\
\text { de } 1966\end{array}$ & $\begin{array}{l}\text { Assembleia } \\
\text { Legislativa } \\
\text { de São } \\
\text { Paulo } \\
\end{array}$ & Projeto de Lei & Discussão & PL 219/64 & $\begin{array}{l}\text { Discurso de } \\
\text { Francisco Moraes. }\end{array}$ \\
\hline $\begin{array}{l}20 \text { de } \\
\text { agosto } \\
\text { de } 1966\end{array}$ & \begin{tabular}{|l|} 
Assembleia \\
Legislativa \\
de São \\
Paulo \\
\end{tabular} & Projeto de Lei & Discussão & PL 219/64 & $\begin{array}{l}\text { Segunda } \\
\text { discussão sobre o } \\
\text { PL 219/64. }\end{array}$ \\
\hline $\begin{array}{l}24 \text { de } \\
\text { agosto } \\
\text { de } 1966\end{array}$ & $\begin{array}{l}\text { Assembleia } \\
\text { Legislativa } \\
\text { de São } \\
\text { Paulo } \\
\end{array}$ & Projeto de Lei & Discussão & PL 219/64 & $\begin{array}{l}\text { Segunda } \\
\text { discussão sobre o } \\
\text { PL 219/64. }\end{array}$ \\
\hline $\begin{array}{l}26 \text { de } \\
\text { agosto } \\
\text { de } 1966\end{array}$ & $\begin{array}{l}\text { Câmara } \\
\text { municipal de } \\
\text { São Paulo } \\
\end{array}$ & $\begin{array}{l}\text { Pronunciamen } \\
\text { to }\end{array}$ & reclamação & & \begin{tabular}{|l|} 
Vereador \\
Benedicto Rocha \\
fala da reforma de \\
interlagos \\
pretendida pelo \\
prefeito Faria Lima.
\end{tabular} \\
\hline
\end{tabular}




\begin{tabular}{|c|c|c|c|c|c|}
\hline $\begin{array}{l}30 \text { de } \\
\text { agosto } \\
\text { de } 1966\end{array}$ & $\begin{array}{l}\text { Assembleia } \\
\text { Legislativa } \\
\text { de São } \\
\text { Paulo } \\
\end{array}$ & $\begin{array}{l}\text { Pronunciamen } \\
\text { to }\end{array}$ & nota de júbilo & & $\begin{array}{l}\text { Nota de júbilo à } \\
\text { Confederação Pan } \\
\text { Americana de } \\
\text { Macabi pela } \\
\text { realização da II } \\
\text { Macabíada. } \\
\end{array}$ \\
\hline $\begin{array}{l}30 \text { de } \\
\text { agosto } \\
\text { de } 1966\end{array}$ & $\begin{array}{l}\text { Assembleia } \\
\text { Legislativa } \\
\text { de São } \\
\text { Paulo } \\
\end{array}$ & Projeto de Lei & Discussão & PL 219/64 & \begin{tabular}{|l|} 
Em discurso no \\
grande expediente \\
o deputado Ary \\
Silva se coloca \\
veementemente \\
contra o projeto. \\
\end{tabular} \\
\hline $\begin{array}{l}01 \text { de } \\
\text { setembr } \\
\text { o de } \\
1966\end{array}$ & $\begin{array}{l}\text { Governo do } \\
\text { Estado de } \\
\text { São Paulo }\end{array}$ & Ato Executivo & Notícia & & $\begin{array}{l}\text { Governo publica a } \\
\text { intenção de } \\
\text { construir, entre } \\
\text { outras coisas, } 21 \\
\text { quadras de esporte } \\
\text { no interior do } \\
\text { estado. }\end{array}$ \\
\hline $\begin{array}{l}06 \text { de } \\
\text { setembr } \\
\text { o de } \\
1966\end{array}$ & $\begin{array}{l}\text { Assembleia } \\
\text { Legislativa } \\
\text { de São } \\
\text { Paulo } \\
\end{array}$ & $\begin{array}{l}\text { Pronunciamen } \\
\text { to }\end{array}$ & $\begin{array}{l}\text { Prestação de } \\
\text { contas }\end{array}$ & & $\begin{array}{l}\text { Deputado Raul } \\
\text { Schwindem fala de } \\
\text { sua visita ao DEFE } \\
\text { para saber dos } \\
\text { progressos sobre a } \\
\text { Escola de } \\
\text { Educação Física } \\
\text { do Estado e se diz } \\
\text { satisfeito. }\end{array}$ \\
\hline $\begin{array}{l}13 \text { de } \\
\text { setembr } \\
\text { o de } \\
1966\end{array}$ & $\begin{array}{l}\text { Assembleia } \\
\text { Legislativa } \\
\text { de São } \\
\text { Paulo } \\
\end{array}$ & $\begin{array}{l}\text { Pronunciamen } \\
\text { to }\end{array}$ & Discussão & & \begin{tabular}{|l} 
Deputado José \\
Lurtz Sabia fala da \\
mensagem do \\
governador sobre o \\
auxílio concedido à \\
Prefeitura de Rio \\
Claro para a \\
realização dos \\
Jogos Abertos do \\
Interior, não se diz \\
contra, mas critica \\
o caráter eleitoreiro \\
e diz que o correto \\
seria apresentar \\
um PL que \\
garantisse a \\
subvenção a \\
qualquer cidade \\
que sediasse os \\
jogos.
\end{tabular} \\
\hline $\begin{array}{l}17 \text { de } \\
\text { setembr } \\
\text { o de } \\
1966\end{array}$ & $\begin{array}{l}\text { Assembleia } \\
\text { Legislativa } \\
\text { de São } \\
\text { Paulo } \\
\end{array}$ & Projeto de Lei & parecer & $\begin{array}{l}\text { PL 148/66, } \\
\text { parecer } 185 / 66\end{array}$ & \begin{tabular}{|l} 
Parecer sobre o \\
projeto de lei sobre \\
a organização do \\
DEFE, criado pela \\
Lei 6882 de \\
18/05/66, favorável \\
com restrições.
\end{tabular} \\
\hline $\begin{array}{l}28 \text { de } \\
\text { setembr } \\
\text { o de } \\
1066\end{array}$ & $\begin{array}{l}\text { Câmara } \\
\text { municipal de } \\
\text { São Paulo } \\
\end{array}$ & Projeto de Lei & discussão & $148 / 66 ?$ & $\begin{array}{l}\text { Primeira discussão } \\
\text { sobre o PL que } \\
\text { dispõe sobre a } \\
\text { criação do DEME - } \\
\text { Departamento }\end{array}$ \\
\hline
\end{tabular}




\begin{tabular}{|c|c|c|c|c|c|}
\hline & & & & & $\begin{array}{l}\text { Municipal de } \\
\text { Esportes. }\end{array}$ \\
\hline $\begin{array}{l}11 \text { de } \\
\text { outubro } \\
\text { de } 1966\end{array}$ & $\begin{array}{l}\text { Câmara } \\
\text { municipal de } \\
\text { São Paulo } \\
\end{array}$ & Projeto de Lei & Informe & $148 / 66$ & $\begin{array}{l}\text { Retirado de pauta } \\
\text { o projeto de lei } \\
\text { 148/66, de autoria } \\
\text { do executivo, por } \\
\text { ter expirado o } \\
\text { prazo para } \\
\text { apreciação, sendo } \\
\text { que de acordo com } \\
\text { o estatuto da casa } \\
\text { o projeto segue } \\
\text { considerado } \\
\text { aprovado. } \\
\end{array}$ \\
\hline $\begin{array}{l}28 \text { de } \\
\text { outubro } \\
\text { de } 1966\end{array}$ & $\begin{array}{l}\text { Assembleia } \\
\text { Legislativa } \\
\text { de São } \\
\text { Paulo } \\
\end{array}$ & $\begin{array}{l}\text { Pronunciamen } \\
\text { to }\end{array}$ & Homenagem & & $\begin{array}{l}\text { Título de cidadão } \\
\text { Emérito a José } \\
\text { Andreatti. }\end{array}$ \\
\hline $\begin{array}{l}28 \text { de } \\
\text { outubro } \\
\text { de } 1966 \\
\end{array}$ & $\begin{array}{l}\text { Assembleia } \\
\text { Legislativa } \\
\text { de São } \\
\text { Paulo } \\
\end{array}$ & $\begin{array}{l}\text { Pronunciamen } \\
\text { to }\end{array}$ & Denúncia & & \begin{tabular}{|l|} 
Deputado Marcos \\
Meligo fala da \\
corrupção eleitoral \\
promovida pela \\
Federação Paulista \\
de Futebol. \\
\end{tabular} \\
\hline $\begin{array}{l}02 \text { de } \\
\text { novembr } \\
\text { o de } \\
1966 \\
\end{array}$ & $\begin{array}{l}\text { Assembleia } \\
\text { Legislativa } \\
\text { de São } \\
\text { Paulo }\end{array}$ & $\begin{array}{l}\text { Pronunciamen } \\
\text { to }\end{array}$ & Denúncia & & \begin{tabular}{|l} 
Denúncia de \\
compra de votos \\
no interior do \\
deputado João \\
Mendonça Falcão, \\
presidente da \\
Federação Paulista \\
de Futebol e Vice \\
Presidente da \\
Assembleia. Em \\
sua defesa \\
discurso o \\
Deputado Hélio \\
Mendonça.
\end{tabular} \\
\hline $\begin{array}{l}19 \text { de } \\
\text { janeiro } \\
\text { de } 1967\end{array}$ & $\begin{array}{l}\text { Câmara } \\
\text { Municipal de } \\
\text { São Paulo }\end{array}$ & $\begin{array}{l}\text { Pronunciamen } \\
\text { to }\end{array}$ & & & $\begin{array}{l}\text { Vereador Ary Silva } \\
\text { fala sobre a } \\
\text { discussão do PL } \\
219 \text { e usa analogia } \\
\text { com o futebol para } \\
\text { enaltecer a } \\
\text { democracia da } \\
\text { discussão. }\end{array}$ \\
\hline $\begin{array}{l}25 \text { de } \\
\text { janeiro } \\
\text { de } 1967\end{array}$ & $\begin{array}{l}\text { Governo de } \\
\text { São Paulo }\end{array}$ & Ato Executivo & Portaria & 3/67/DEFE & $\begin{array}{l}\text { Regulamento do } \\
\text { Campeonato } \\
\text { Colegial. } \\
\end{array}$ \\
\hline $\begin{array}{l}27 \text { de } \\
\text { janeiro } \\
\text { de } 1967\end{array}$ & $\begin{array}{l}\text { Governo de } \\
\text { São Paulo }\end{array}$ & Ato Executivo & Portaria & 4/67/DEFE & $\begin{array}{l}\text { Altera regulamento } \\
\text { do Troféu } \\
\text { Bandeirantes. }\end{array}$ \\
\hline $\begin{array}{l}28 \text { de } \\
\text { março } \\
\text { de } 1967\end{array}$ & $\begin{array}{l}\text { Câmara } \\
\text { Municipal de } \\
\text { São Paulo }\end{array}$ & $\begin{array}{l}\text { Pronunciamen } \\
\text { to }\end{array}$ & Discussão & & $\begin{array}{l}\text { Críticas no plenário } \\
\text { sobre o Coronel } \\
\text { Fontenelle e o } \\
\text { Grupo Fontenelle, } \\
\text { citam operação } \\
\text { bandeirantes - }\end{array}$ \\
\hline
\end{tabular}




\begin{tabular}{|c|c|c|c|c|c|}
\hline & & & & & \begin{tabular}{|l} 
problemas do \\
transporte público \\
e da \\
impossibilidade de \\
os trabalhadores \\
irem aos jogos no \\
Pacaembu.
\end{tabular} \\
\hline $\begin{array}{l}28 \text { de } \\
\text { março } \\
\text { de } 1967\end{array}$ & $\begin{array}{l}\text { Câmara } \\
\text { Municipal de } \\
\text { São Paulo } \\
\end{array}$ & $\begin{array}{l}\begin{array}{l}\text { Pronunciamen } \\
\text { to }\end{array} \\
\end{array}$ & Explanação & & $\begin{array}{l}\text { Vereador Tabajara } \\
\text { Vidigal Leitão } \\
\text { justifica sua moção } \\
\text { contrária à portaria } \\
\text { que proibia a } \\
\text { entrada de } \\
\text { menores de } 21 \\
\text { anos no } \\
\text { Hipódromo de São } \\
\text { Paulo. } \\
\end{array}$ \\
\hline $\begin{array}{l}18 \text { de } \\
\text { abril de } \\
1967\end{array}$ & $\begin{array}{l}\text { Assembleia } \\
\text { Legislativa } \\
\text { de São } \\
\text { Paulo } \\
\end{array}$ & $\begin{array}{l}\text { Pronunciamen } \\
\text { to }\end{array}$ & Discussão & & $\begin{array}{l}\text { Discussão sobre } \\
\text { os gastos da Caixa } \\
\text { Econômica com } \\
\text { propaganda } \\
\text { durante eventos } \\
\text { esportivos. } \\
\text { Deputado Ary Silva } \\
\text { defende a prática, } \\
\text { e diz que "o } \\
\text { homem do esporte } \\
\text { principalmente o } \\
\text { homem do futebol, } \\
\text { é o homem que } \\
\text { deposita suas } \\
\text { economias nas } \\
\text { caixas econômicas } \\
\text { - não acredita } \\
\text { muito em bancos". }\end{array}$ \\
\hline $\begin{array}{l}03 \text { de } \\
\text { maio de } \\
1967\end{array}$ & $\begin{array}{l}\text { Câmara } \\
\text { Municipal de } \\
\text { São Paulo }\end{array}$ & Indicação & Ao executivo & $333 / 67$ & $\begin{array}{l}\text { Vereador } \\
\text { Francisco Batista } \\
\text { pede ao Prefeito } \\
\text { que proceda com } \\
\text { ajuda financeira } \\
\text { aos clubes de São } \\
\text { Paulo que existam } \\
\text { a mais de } 20 \text { anos } \\
\text { para ampliação de } \\
\text { suas sedes. }\end{array}$ \\
\hline $\begin{array}{l}05 \text { de } \\
\text { maio de } \\
1967\end{array}$ & \begin{tabular}{|l} 
Assembleia \\
Legislativa \\
de São \\
Paulo \\
\end{tabular} & $\begin{array}{l}\text { Pronunciamen } \\
\text { to }\end{array}$ & Discussão & & $\begin{array}{l}\text { Deputado Avallone } \\
\text { Junior pede que } \\
\text { seja logo posto em } \\
\text { votação projeto da } \\
\text { loteria estadual da } \\
\text { qual as rendas } \\
\text { seriam destinadas } \\
\text { as Santas Casas } \\
\text { de misericórdia e } \\
\text { ao esporte amador }\end{array}$ \\
\hline
\end{tabular}




\begin{tabular}{|c|c|c|c|c|c|}
\hline \begin{tabular}{|l}
05 de \\
maio de \\
1967 \\
\end{tabular} & $\begin{array}{l}\text { Câmara } \\
\text { Municipal de } \\
\text { São Paulo }\end{array}$ & Requerimento & Ao executivo & $205 / 67$ & $\begin{array}{l}\text { Vereador Monteiro } \\
\text { Carvalho solicita } \\
\text { que o Prefeito se } \\
\text { informe com a } \\
\text { Secretaria de } \\
\text { Finanças sobre } \\
\text { verba doada pelo } \\
\text { Setor Social da } \\
\text { Industria, no valor } \\
\text { de CR } \$ \\
12.000 .000,00 \text { para } \\
\text { o CME-Conselho } \\
\text { Municipal de } \\
\text { Esportes, para } \\
\text { compra de } \\
\text { equipamentos para } \\
\text { os clubes } \\
\text { varzeanos. }\end{array}$ \\
\hline $\begin{array}{l}30 \text { de } \\
\text { maio de } \\
1967\end{array}$ & $\begin{array}{l}\text { Câmara } \\
\text { Municipal de } \\
\text { São Paulo }\end{array}$ & $\begin{array}{l}\text { Pronunciamen } \\
\text { to }\end{array}$ & Discussão & & $\begin{array}{l}\text { Vereador Monteiro } \\
\text { Carvalho faz fala } \\
\text { contraria ao } \\
\text { aumento de preços } \\
\text { no ingresso no } \\
\text { Pacaembu, e fala } \\
\text { que a Federação e } \\
\text { a CBD deveriam } \\
\text { ter estádios } \\
\text { próprios, visto que } \\
\text { já possuem lucros } \\
\text { imensos, e } \\
\text { defende que o } \\
\text { Pacaembu seja } \\
\text { destinado ao } \\
\text { esporte amador. }\end{array}$ \\
\hline \begin{tabular}{|l}
31 de \\
maio de \\
1967 \\
\end{tabular} & $\begin{array}{l}\text { Câmara } \\
\text { municipal de } \\
\text { São Paulo } \\
\end{array}$ & $\begin{array}{l}\text { Pronunciamen } \\
\text { to }\end{array}$ & Discussão & & \begin{tabular}{|l|} 
Vereador Pereira \\
Barreto retoma a \\
discussão sobre o \\
Autódromo. \\
\end{tabular} \\
\hline \begin{tabular}{|l}
09 de \\
junho de \\
1967
\end{tabular} & $\begin{array}{l}\text { Assembleia } \\
\text { Legislativa } \\
\text { de São } \\
\text { Paulo } \\
\end{array}$ & $\begin{array}{l}\text { Pronunciamen } \\
\text { to }\end{array}$ & Discussão & & \begin{tabular}{|l|} 
Deputado Orlando \\
Junior e deputado \\
Chopin Tavares \\
discordam sobre a \\
criação de uma \\
comissão estadual \\
de esportes dentro \\
da casa. \\
\end{tabular} \\
\hline $\begin{array}{l}10 \text { de } \\
\text { junho de } \\
1967\end{array}$ & $\begin{array}{l}\text { Governo de } \\
\text { São Paulo }\end{array}$ & Ato Executivo & Homenagem & & $\begin{array}{l}\text { Homenagem ao } \\
\text { Palmeiras no } \\
\text { Palácio dos } \\
\text { Bandeirantes. } \\
\end{array}$ \\
\hline $\begin{array}{l}15 \text { de } \\
\text { junho de } \\
1967\end{array}$ & $\begin{array}{l}\text { Assembleia } \\
\text { Legislativa } \\
\text { de São } \\
\text { Paulo }\end{array}$ & Requerimento & $\begin{array}{l}\text { prestação de } \\
\text { contas }\end{array}$ & & $\begin{array}{l}\text { Pede-se ao poder } \\
\text { executivo } \\
\text { informações sobre } \\
\text { as providências } \\
\text { tomadas para } \\
\text { atender o artigo } \\
127, \text { "in fine" da } \\
\text { Constituição do } \\
\text { Estado, ou seja, } \\
\text { formar grupo de }\end{array}$ \\
\hline
\end{tabular}




\begin{tabular}{|c|c|c|c|c|c|}
\hline & & & & & $\begin{array}{l}\text { estudos para } \\
\text { formar e } \\
\text { apresentar para a } \\
\text { Assembleia projeto } \\
\text { de lei que dispõe } \\
\text { sobre o sistema } \\
\text { estadual de } \\
\text { desportos. }\end{array}$ \\
\hline $\begin{array}{l}15 \text { de } \\
\text { junho de } \\
1967\end{array}$ & $\begin{array}{l}\text { Câmara } \\
\text { Municipal de } \\
\text { São Paulo } \\
\end{array}$ & $\begin{array}{l}\text { Pronunciamen } \\
\text { to }\end{array}$ & Homenagem & & $\begin{array}{l}\text { Voto de } \\
\text { congratulações à } \\
\text { Moacyr Arruda, } \\
\text { "líder varzeano". }\end{array}$ \\
\hline $\begin{array}{l}8 \text { de } \\
\text { agosto } \\
\text { de } 1967\end{array}$ & $\begin{array}{l}\text { Câmara } \\
\text { Municipal de } \\
\text { São Paulo }\end{array}$ & $\begin{array}{l}\text { Pronunciamen } \\
\text { to }\end{array}$ & nota de pesar & & $\begin{array}{l}\text { Nota de pesar } \\
\text { sobre a morte de } \\
\text { Hermano } \\
\text { Marchetti, ex- } \\
\text { presidente da } \\
\text { Federação Paulista } \\
\text { de Ciclismo e } \\
\text { vereador da casa. }\end{array}$ \\
\hline $\begin{array}{l}31 \text { de } \\
\text { agosto } \\
\text { de } 1967\end{array}$ & $\begin{array}{l}\text { Assembleia } \\
\text { Legislativa } \\
\text { de São } \\
\text { Paulo } \\
\end{array}$ & $\begin{array}{l}\text { Pronunciamen } \\
\text { to }\end{array}$ & Homenagem & & $\begin{array}{l}\text { Nota de júbilo a } \\
\text { atleta Noêmia } \\
\text { Assumpção, pelo } \\
\text { decorrer de } 12 \\
\text { anos do seu jubileu } \\
\text { de Prata no } \\
\text { Atletismo } \\
\text { Brasileiro. }\end{array}$ \\
\hline $\begin{array}{l}19 \text { de } \\
\text { setembr } \\
\text { o de } \\
1967\end{array}$ & $\begin{array}{l}\text { Câmara } \\
\text { Municipal de } \\
\text { São Paulo } \\
\end{array}$ & Requerimento & Homenagem & P835/67 & $\begin{array}{l}\text { Congratulações ao } \\
\text { Estrela Saúde FC } \\
\text { pelo seu } \\
\text { cinquentenário. }\end{array}$ \\
\hline $\begin{array}{l}19 \text { de } \\
\text { setembr } \\
\text { o de } \\
1967\end{array}$ & $\begin{array}{l}\text { Câmara } \\
\text { Municipal de } \\
\text { São Paulo }\end{array}$ & Requerimento & Ao executivo & $2826 / 67$ & $\begin{array}{l}\text { vereador Sender } \\
\text { Fichman faz } \\
\text { requerimento ao } \\
\text { prefeito para a } \\
\text { ampliação do } \\
\text { Pacaembu. }\end{array}$ \\
\hline $\begin{array}{l}20 \text { de } \\
\text { setembr } \\
\text { o de } \\
1967\end{array}$ & $\begin{array}{l}\text { Assembleia } \\
\text { Legislativa } \\
\text { de São } \\
\text { Paulo } \\
\end{array}$ & Requerimento & Homenagem & $877 / 67$ & $\begin{array}{l}\text { Voto de } \\
\text { congratulações ao } \\
\text { E.C Corinthians } \\
\text { pelo seu } 57^{\circ} \\
\text { aniversário. }\end{array}$ \\
\hline $\begin{array}{l}29 \text { de } \\
\text { setembr } \\
\text { o de } \\
1967\end{array}$ & $\begin{array}{l}\text { Câmara } \\
\text { Municipal de } \\
\text { São Paulo } \\
\end{array}$ & $\begin{array}{l}\text { Pronunciamen } \\
\text { to }\end{array}$ & Ao executivo & & $\begin{array}{l}\text { Vereador Mauro } \\
\text { Hernani Costa } \\
\text { pede ao Prefeito e } \\
\text { ao Ministro dos } \\
\text { Transportes } \\
\text { atenção com a } \\
\text { Federação Paulista } \\
\text { de Columbofilia } \\
\text { (pombos-correios). }\end{array}$ \\
\hline $\begin{array}{l}03 \text { de } \\
\text { outubro } \\
\text { de } 1967\end{array}$ & $\begin{array}{l}\text { Assembleia } \\
\text { Legislativa } \\
\text { de São } \\
\text { Paulo }\end{array}$ & Indicação & Ao executivo & & $\begin{array}{l}\text { Deputado Salim } \\
\text { Tomé faz indicação } \\
\text { ao executivo para } \\
\text { estudar a } \\
\text { possibilidade de se } \\
\text { usar terreno da } \\
\text { cavalaria paulista } \\
\text { para construção de }\end{array}$ \\
\hline
\end{tabular}




\begin{tabular}{|c|c|c|c|c|c|}
\hline & & & & & $\begin{array}{l}\text { centro de esportes } \\
\text { no município de } \\
\text { Colina. }\end{array}$ \\
\hline $\begin{array}{l}12 \text { de } \\
\text { outubro } \\
\text { de } 1967\end{array}$ & $\begin{array}{l}\text { Assembleia } \\
\text { Legislativa } \\
\text { de São } \\
\text { Paulo } \\
\end{array}$ & $\begin{array}{l}\text { Pronunciamen } \\
\text { to }\end{array}$ & Homenagem & & \begin{tabular}{|l|} 
Deputado Wadih \\
Helu faz discurso \\
sobre os 20 anos \\
da Gazeta \\
Esportiva. \\
\end{tabular} \\
\hline $\begin{array}{l}14 \text { de } \\
\text { outubro } \\
\text { de } 1967\end{array}$ & $\begin{array}{l}\text { Assembleia } \\
\text { Legislativa } \\
\text { de São } \\
\text { Paulo } \\
\end{array}$ & $\begin{array}{l}\text { Pronunciamen } \\
\text { to }\end{array}$ & Discussão & & $\begin{array}{l}\text { Deputado Roberto } \\
\text { Rollemberg faz } \\
\text { críticas ao DEFE e } \\
\text { diz que esse } \\
\text { abandonou o } \\
\text { esporte paulista. } \\
\end{array}$ \\
\hline $\begin{array}{l}17 \text { de } \\
\text { outubro } \\
\text { de } 1967 \\
\end{array}$ & $\begin{array}{l}\text { Câmara } \\
\text { Municipal de } \\
\text { São Paulo } \\
\end{array}$ & $\begin{array}{l}\text { Pronunciamen } \\
\text { to }\end{array}$ & Homenagem & & $\begin{array}{l}\text { Vereador Leonard } \\
\text { Marco fala em } \\
\text { homenagem a } \\
\text { Gazeta Esportiva. } \\
\end{array}$ \\
\hline $\begin{array}{l}17 \text { de } \\
\text { outubro } \\
\text { de } 1967\end{array}$ & \begin{tabular}{|l} 
Assembleia \\
Legislativa \\
de São \\
Paulo \\
\end{tabular} & $\begin{array}{l}\text { Pronunciamen } \\
\text { to }\end{array}$ & Discussão & & $\begin{array}{l}\text { Fala contra a CBD } \\
\text { na Alesp. }\end{array}$ \\
\hline $\begin{array}{l}18 \text { de } \\
\text { outubro } \\
\text { de } 1967\end{array}$ & $\begin{array}{l}\text { Assembleia } \\
\text { Legislativa } \\
\text { de São } \\
\text { Paulo } \\
\end{array}$ & $\begin{array}{l}\text { Pronunciamen } \\
\text { to }\end{array}$ & & & \begin{tabular}{|l|} 
Deputado Wadih \\
Helu fala sobre os \\
jogos do Colegial \\
realizados em São \\
José dos Campos.
\end{tabular} \\
\hline $\begin{array}{l}20 \text { de } \\
\text { outubro } \\
\text { de } 1967\end{array}$ & \begin{tabular}{|l} 
Câmara \\
Municipal de \\
São Paulo \\
\end{tabular} & $\begin{array}{l}\text { Pronunciamen } \\
\text { to }\end{array}$ & Homenagem & & \begin{tabular}{|l} 
Fala de \\
congratulações a \\
Gazeta Esportiva - \\
pela realização da \\
V Volta ciclística do \\
Interior do Estado \\
de São Paulo - e \\
ao vereador José \\
Maria Marin. \\
\end{tabular} \\
\hline $\begin{array}{l}26 \text { de } \\
\text { outubro } \\
\text { de } 1967\end{array}$ & $\begin{array}{l}\text { Governo do } \\
\text { Estado de } \\
\text { São Paulo }\end{array}$ & Ato Executivo & Resolução & $1953 / 25 / 10 / 67$ & $\begin{array}{l}\text { Institui Comissão } \\
\text { Especial para } \\
\text { proceder a } \\
\text { elaboração de } \\
\text { anteprojeto de lei } \\
\text { dispondo sobre o } \\
\text { amparo ao esporte, } \\
\text { nos termos do } \\
\text { artigo } 127 \text { da } \\
\text { Constituição do } \\
\text { Estado de São } \\
\text { Paulo. }\end{array}$ \\
\hline $\begin{array}{l}01 \text { de } \\
\text { novembr } \\
\text { o de } \\
1967 \\
\end{array}$ & $\begin{array}{l}\text { Governo do } \\
\text { Estado de } \\
\text { São Paulo } \\
\end{array}$ & Rotina & & & $\begin{array}{l}\text { Governador recebe } \\
\text { no Palácio dos } \\
\text { Bandeirantes a } \\
\text { Seleção Paulista } \\
\text { de Novos junto } \\
\text { com o deputado } \\
\text { João Mendonça } \\
\text { Falcão, Presidente } \\
\text { da Federação } \\
\text { Paulista de } \\
\text { Futebol. } \\
\end{array}$ \\
\hline
\end{tabular}




\begin{tabular}{|c|c|c|c|c|c|}
\hline $\begin{array}{l}01 \text { de } \\
\text { novembr } \\
\text { o de } \\
1967\end{array}$ & $\begin{array}{l}\text { Assembleia } \\
\text { Legislativa } \\
\text { de São } \\
\text { Paulo }\end{array}$ & $\begin{array}{l}\text { Pronunciamen } \\
\text { to }\end{array}$ & Discussão & & \begin{tabular}{|l} 
Fala dos \\
deputados \\
Marcondes Pereira \\
e Avallone Junior \\
sobre o esporte \\
amador no estado.
\end{tabular} \\
\hline $\begin{array}{l}02 \text { de } \\
\text { novembr } \\
\text { o de } \\
1967\end{array}$ & $\begin{array}{l}\text { Governo do } \\
\text { Estado de } \\
\text { São Paulo }\end{array}$ & Ato Executivo & Conveniamento & & $\begin{array}{l}\text { Governo } \\
\text { estabelece dois } \\
\text { convênios com a } \\
\text { Associação dos } \\
\text { Professores de } \\
\text { Educação Física } \\
\text { do Estado de São } \\
\text { Paulo. O primeiro } \\
\text { para realizar visitas } \\
\text { técnicas no interior } \\
\text { do Estado, o } \\
\text { segundo para } \\
\text { elaboração de } \\
\text { revista técnica } \\
\text { mensal. }\end{array}$ \\
\hline $\begin{array}{l}04 \text { de } \\
\text { novembr } \\
\text { o de } \\
1967\end{array}$ & $\begin{array}{l}\text { Governo do } \\
\text { Estado de } \\
\text { São Paulo }\end{array}$ & Ato Executivo & Publicidade & & $\begin{array}{l}\text { Anúncio da posse } \\
\text { da comissão que } \\
\text { vai elaborar o } \\
\text { anteprojeto de } \\
\text { amparo ao esporte. }\end{array}$ \\
\hline $\begin{array}{l}08 \text { de } \\
\text { novembr } \\
\text { o de } \\
1967\end{array}$ & $\begin{array}{l}\text { Governo do } \\
\text { Estado de } \\
\text { São Paulo }\end{array}$ & Ato Executivo & Publicidade & & $\begin{array}{l}\text { Anúncio da posse } \\
\text { da comissão que } \\
\text { vai elaborar o } \\
\text { anteprojeto de } \\
\text { amparo ao esporte. }\end{array}$ \\
\hline $\begin{array}{l}10 \text { de } \\
\text { novembr } \\
\text { o de } \\
1967\end{array}$ & $\begin{array}{l}\text { Câmara } \\
\text { Municipal de } \\
\text { São Paulo } \\
\end{array}$ & Projeto de Lei & Discussão & $116 / 67$ & $\begin{array}{l}\text { Vereador Sugai } \\
\text { fala do PL } 116 \text { que } \\
\text { visa ceder por } 40 \\
\text { anos terreno para } \\
\text { o Centro das } \\
\text { Indústrias para } \\
\text { construção do } \\
\text { Parque Anhembi. }\end{array}$ \\
\hline $\begin{array}{l}17 \text { de } \\
\text { novembr } \\
\text { o de } \\
1967\end{array}$ & $\begin{array}{l}\text { Câmara } \\
\text { Municipal de } \\
\text { São Paulo } \\
\end{array}$ & $\begin{array}{l}\text { Ato } \\
\text { Legislativo }\end{array}$ & Comissão & & $\begin{array}{l}\text { Sai a lista da } \\
\text { comissão de } \\
\text { esportes. }\end{array}$ \\
\hline $\begin{array}{l}22 \text { de } \\
\text { novembr } \\
\text { o de } \\
1967\end{array}$ & $\begin{array}{l}\text { Assembleia } \\
\text { Legislativa } \\
\text { de São } \\
\text { Paulo } \\
\end{array}$ & $\begin{array}{l}\text { Pronunciamen } \\
\text { to }\end{array}$ & Discussão & & $\begin{array}{l}\text { Deputado Solon } \\
\text { Borges dos Reis } \\
\text { critica a CBD por } \\
\text { não proceder com } \\
\text { a preparação dos } \\
\text { atletas brasileiros } \\
\text { para se } \\
\text { acostumarem com } \\
\text { a altitude do } \\
\text { México, visto que } \\
\text { as Olimpíadas se } \\
\text { aproximavam. }\end{array}$ \\
\hline $\begin{array}{l}24 \text { de } \\
\text { novembr } \\
\text { o de } \\
1967\end{array}$ & $\begin{array}{l}\text { Assembleia } \\
\text { Legislativa } \\
\text { de São } \\
\text { Paulo } \\
\end{array}$ & Projeto de Lei & Parecer & $1108 / P L 590 / 67$ & $\begin{array}{l}\text { Parecer favorável } \\
\text { ao projeto de lei do } \\
\text { deputado Avallone } \\
\text { Junior que visa a } \\
\text { construção de }\end{array}$ \\
\hline
\end{tabular}




\begin{tabular}{|c|c|c|c|c|c|}
\hline & & & & & $\begin{array}{l}\text { ginásio de esportes } \\
\text { em Bauru. }\end{array}$ \\
\hline $\begin{array}{l}28 \text { de } \\
\text { novembr } \\
\text { o de } \\
1967 \\
\end{array}$ & \begin{tabular}{|l} 
Câmara \\
Municipal de \\
São Paulo \\
\end{tabular} & $\begin{array}{l}\text { Pronunciamen } \\
\text { to }\end{array}$ & Ao executivo & & $\begin{array}{l}\text { Vereador Antônio } \\
\text { Sampaio pede ao } \\
\text { Prefeito que } \\
\text { arrume outros } \\
\text { terrenos para a } \\
\text { construção de } \\
\text { campos para } \\
\text { atender diversos } \\
\text { times de várzea, } \\
\text { uma vez que o } \\
\text { terreno onde } \\
\text { jogavam vai ser } \\
\text { cedido ao Centro } \\
\text { das Indústrias. } \\
\end{array}$ \\
\hline $\begin{array}{l}29 \text { de } \\
\text { novembr } \\
\text { o de } \\
1967\end{array}$ & $\begin{array}{l}\text { Assembleia } \\
\text { Legislativa } \\
\text { de São } \\
\text { Paulo } \\
\end{array}$ & $\begin{array}{l}\text { Pronunciamen } \\
\text { to }\end{array}$ & Discussão & & $\begin{array}{l}\text { Discussão na } \\
\text { Alesp sobre futebol } \\
\text { amador. }\end{array}$ \\
\hline $\begin{array}{l}29 \text { de } \\
\text { novembr } \\
\text { o de } \\
1967\end{array}$ & $\begin{array}{l}\text { Assembleia } \\
\text { Legislativa } \\
\text { de São } \\
\text { Paulo }\end{array}$ & Requerimento & & 1536 & $\begin{array}{l}\text { Requerimento para } \\
\text { a constituição de } \\
\text { comissão na } \\
\text { Assembleia sobre } \\
\text { esportes formada } \\
\text { por } 5 \text { deputados. }\end{array}$ \\
\hline $\begin{array}{l}29 \text { de } \\
\text { novembr } \\
\text { o de } \\
1967\end{array}$ & $\begin{array}{l}\text { Câmara } \\
\text { Municipal de } \\
\text { São Paulo } \\
\end{array}$ & $\begin{array}{l}\text { Pronunciamen } \\
\text { to }\end{array}$ & Discussão & & $\begin{array}{l}\text { Vereador Sander } \\
\text { Fichman fala sobre } \\
\text { a falta de lugares } \\
\text { para a prática de } \\
\text { esportes na cidade } \\
\text { de São Paulo. } \\
\end{array}$ \\
\hline $\begin{array}{l}30 \text { de } \\
\text { novembr } \\
\text { o de } \\
1967 \\
\end{array}$ & $\begin{array}{l}\text { Câmara } \\
\text { Municipal de } \\
\text { São Paulo } \\
\end{array}$ & $\begin{array}{l}\text { Ato } \\
\text { Legislativo }\end{array}$ & Resolução & & \begin{tabular}{|l|} 
Comissão de \\
Constituição e \\
Justiça autoriza a \\
prefeitura a \\
proceder com \\
Conveniamento \\
com entidades \\
esportivas. \\
\end{tabular} \\
\hline $\begin{array}{l}30 \text { de } \\
\text { novembr } \\
\text { o de } \\
1967 \\
\end{array}$ & $\begin{array}{l}\text { Câmara } \\
\text { Municipal de } \\
\text { São Paulo } \\
\end{array}$ & $\begin{array}{l}\text { Pronunciamen } \\
\text { to }\end{array}$ & Discussão & & $\begin{array}{l}\text { Vereador Tabajara } \\
\text { Vidigal fala em } \\
\text { favor da luta livre. }\end{array}$ \\
\hline $\begin{array}{l}01 \text { de } \\
\text { dezembr } \\
\text { o de } \\
1967\end{array}$ & $\begin{array}{l}\text { Governo do } \\
\text { Estado de } \\
\text { São Paulo } \\
\end{array}$ & Ato Executivo & Resolução & & $\begin{array}{l}\text { Criada inspetoria } \\
\text { de esportes ligada } \\
\text { ao DEFE na cidade } \\
\text { de Monte } \\
\text { Aprazível. } \\
\end{array}$ \\
\hline $\begin{array}{l}08 \text { de } \\
\text { dezembr } \\
\text { o de } \\
1967\end{array}$ & $\begin{array}{l}\text { Assembleia } \\
\text { Legislativa } \\
\text { de São } \\
\text { Paulo } \\
\end{array}$ & $\begin{array}{l}\text { Ato } \\
\text { Legislativo }\end{array}$ & Resolução & & \begin{tabular}{|l} 
Define-se \\
Comissão de \\
Esportes da \\
Assembleia, \\
composta pelos \\
deputados \\
Benedito \\
Matarazzo, \\
Salvados Julianetti,
\end{tabular} \\
\hline
\end{tabular}




\begin{tabular}{|c|c|c|c|c|c|}
\hline & & & & & \begin{tabular}{|l} 
Geraldino dos \\
Santos, Mario \\
Telez Ruez Silva, \\
Guilherme Gomes, \\
Mendonça Falcão, \\
Jacinto Figueira \\
Jr., Egídio Semora, \\
Alex Freira Neto.
\end{tabular} \\
\hline $\begin{array}{l}12 \text { de } \\
\text { dezembr } \\
\text { o de } \\
1967\end{array}$ & $\begin{array}{l}\text { Assembleia } \\
\text { Legislativa } \\
\text { de São } \\
\text { Paulo } \\
\end{array}$ & $\begin{array}{l}\text { Pronunciamen } \\
\text { to }\end{array}$ & Discussão & & $\begin{array}{l}\text { Nova fala na } \\
\text { Assembleia sobre } \\
\text { falta de estrutura } \\
\text { para o esporte } \\
\text { amador no Estado. }\end{array}$ \\
\hline $\begin{array}{l}20 \text { de } \\
\text { dezembr } \\
\text { o de } \\
1967\end{array}$ & $\begin{array}{l}\text { Governo do } \\
\text { Estado de } \\
\text { São Paulo }\end{array}$ & Ato Executivo & Resolução & & $\begin{array}{l}\text { Governo oficializa } \\
\text { corrida de São } \\
\text { Silvestre. }\end{array}$ \\
\hline $\begin{array}{l}28 \text { de } \\
\text { dezembr } \\
\text { o de } \\
1967 \\
\end{array}$ & $\begin{array}{l}\text { Câmara } \\
\text { municipal de } \\
\text { São Paulo } \\
\end{array}$ & Requerimento & Ao executivo & 4705 & $\begin{array}{l}\text { Requerimento ao } \\
\text { Prefeito de São } \\
\text { Paulo para } \\
\text { ampliação do } \\
\text { Pacaembu. }\end{array}$ \\
\hline \begin{tabular}{|l}
29 de \\
dezembr \\
o de \\
1967 \\
\end{tabular} & $\begin{array}{l}\text { Câmara } \\
\text { Municipal de } \\
\text { São Paulo } \\
\end{array}$ & Requerimento & Ao executivo & 4762 & $\begin{array}{l}\text { Requerimento ao } \\
\text { Prefeito de São } \\
\text { Paulo para } \\
\text { ampliação da } \\
\text { Avenida Francisco } \\
\text { Matarazzo (pelo } \\
\text { Palmeiras). } \\
\end{array}$ \\
\hline \begin{tabular}{|l}
30 de \\
dezembr \\
o de \\
1967 \\
\end{tabular} & $\begin{array}{l}\text { Governo do } \\
\text { Estado de } \\
\text { São Paulo } \\
\end{array}$ & Ato Executivo & Decreto & $46165 / 67$ & $\begin{array}{l}\text { Dispõe sobre a } \\
\text { reforma } \\
\text { administrativa das } \\
\text { atividades de } \\
\text { promoção social, } \\
\text { cultura, educação } \\
\text { física, esporte e } \\
\text { turismo. }\end{array}$ \\
\hline $\begin{array}{l}03 \text { de } \\
\text { janeiro } \\
\text { de } 1968\end{array}$ & $\begin{array}{l}\text { Governo do } \\
\text { Estado de } \\
\text { São Paulo }\end{array}$ & Ato Executivo & Decreto & $46165 / 67$ & $\begin{array}{l}\text { Dispõe sobre a } \\
\text { reforma } \\
\text { administrativa das } \\
\text { atividades de } \\
\text { promoção social, } \\
\text { cultura, educação } \\
\text { física, esporte e } \\
\text { turismo. }\end{array}$ \\
\hline $\begin{array}{l}20 \text { de } \\
\text { janeiro } \\
\text { de } 1968\end{array}$ & $\begin{array}{l}\text { Governo do } \\
\text { Estado de } \\
\text { São Paulo } \\
\end{array}$ & Ato Executivo & Portaria & Portaria 04 & $\begin{array}{l}\text { Portaria do DEFE } \\
\text { designa o Sr. José } \\
\text { Alcino Beniti para } \\
\text { ser responsável } \\
\text { por toda a } \\
\text { comunicação sobre } \\
\text { esportes. } \\
\end{array}$ \\
\hline $\begin{array}{l}20 \text { de } \\
\text { janeiro } \\
\text { de } 1968\end{array}$ & $\begin{array}{l}\text { Governo do } \\
\text { Estado de } \\
\text { São Paulo }\end{array}$ & Ato Executivo & Resolução & & \begin{tabular}{|l|} 
Determina que \\
todo o processo \\
que envolva \\
liberação de \\
verbas passe antes \\
pelo gabinete do \\
Secretário.
\end{tabular} \\
\hline
\end{tabular}




\begin{tabular}{|c|c|c|c|c|}
\hline $\begin{array}{l}23 \text { de } \\
\text { janeiro } \\
\text { de } 1968\end{array}$ & $\begin{array}{l}\text { Governo do } \\
\text { Estado de } \\
\text { São Paulo }\end{array}$ & & Publicidade & $\begin{array}{l}\text { Nota sobre visita } \\
\text { do Secretário a } \\
\text { Ribeirão Preto para } \\
\text { a cerimônia de } \\
\text { assinatura de } \\
\text { termo de } \\
\text { financiamento pela } \\
\text { Caixa Econômica } \\
\text { do Estado de São } \\
\text { Paulo para a } \\
\text { construção de } \\
\text { sede da Sociedade } \\
\text { Recreativa e de } \\
\text { Esportes da } \\
\text { Cidade. Presença } \\
\text { do Secretário de } \\
\text { Economia e } \\
\text { Planejamento. }\end{array}$ \\
\hline $\begin{array}{l}23 \text { de } \\
\text { janeiro } \\
\text { de } 1968\end{array}$ & $\begin{array}{l}\text { Governo do } \\
\text { Estado de } \\
\text { São Paulo }\end{array}$ & Ato Executivo & Publicidade & $\begin{array}{l}\text { Abertas } 44 \\
\text { licitações para } \\
\text { reforma e reparo, } \\
\text { entre elas algumas } \\
\text { para equipamentos } \\
\text { esportivos. }\end{array}$ \\
\hline $\begin{array}{l}24 \text { de } \\
\text { janeiro } \\
\text { de } 1968\end{array}$ & $\begin{array}{l}\text { Assembleia } \\
\text { Legislativa } \\
\text { de São } \\
\text { Paulo } \\
\end{array}$ & $\begin{array}{l}\text { Pronunciamen } \\
\text { to }\end{array}$ & Discussão & \begin{tabular}{|l} 
Deputado Orlando \\
Zanconer fala \\
sobre o plano \\
estadual de \\
esporte. \\
\end{tabular} \\
\hline $\begin{array}{l}25 \text { de } \\
\text { janeiro } \\
\text { de } 1968\end{array}$ & $\begin{array}{l}\text { Governo do } \\
\text { Estado de } \\
\text { São Paulo } \\
\end{array}$ & & Homenagem & $\begin{array}{l}\text { Homenagem do } \\
\text { governo a } \\
\text { delegação do } \\
\text { Benfica. } \\
\end{array}$ \\
\hline $\begin{array}{l}02 \text { de } \\
\text { fevereiro } \\
\text { de } 1968 \\
\end{array}$ & $\begin{array}{l}\text { Governo do } \\
\text { Estado de } \\
\text { São Paulo } \\
\end{array}$ & Rotina & & $\begin{array}{l}\text { Reunião de } \\
\text { delegados do } \\
\text { interior com } \\
\text { técnicos do DEFE } \\
\text { para organizar } \\
\text { calendário anual } \\
\text { esportivo. } \\
\end{array}$ \\
\hline $\begin{array}{l}07 \text { de } \\
\text { fevereiro } \\
\text { de } 1968\end{array}$ & $\begin{array}{l}\text { Governo do } \\
\text { Estado de } \\
\text { São Paulo } \\
\end{array}$ & Ato Executivo & & $\begin{array}{l}\text { Governador Abreu } \\
\text { Sodré apoia plano } \\
\text { de esporte } \\
\text { estadual elaborado } \\
\text { pela pasta no } \\
\text { comando do } \\
\text { deputado Orlando } \\
\text { Zanconer. Foco no } \\
\text { esporte amador. } \\
\end{array}$ \\
\hline $\begin{array}{l}14 \text { de } \\
\text { fevereiro } \\
\text { de } 1968\end{array}$ & \begin{tabular}{|l} 
Governo do \\
Estado de \\
São Paulo \\
\end{tabular} & Ato Executivo & Recomendação & \begin{tabular}{|l|} 
Secretário Orlado \\
Zanconer \\
recomenda a \\
Padilha que ceda a \\
franquia postal da \\
secretaria a \\
Comissão de \\
Amparo ao esporte \\
para facilitar \\
comunicação com \\
\end{tabular} \\
\hline
\end{tabular}




\begin{tabular}{|c|c|c|c|c|c|}
\hline & & & & & $\begin{array}{l}\text { entidades do } \\
\text { interior do Estado. }\end{array}$ \\
\hline $\begin{array}{l}16 \text { de } \\
\text { fevereiro } \\
\text { de } 1968\end{array}$ & $\begin{array}{l}\text { Governo do } \\
\text { Estado de } \\
\text { São Paulo }\end{array}$ & Portaria & DEFE & 368 & $\begin{array}{l}\text { Dispõe sobre o } \\
\text { Campeonato } \\
\text { Colegial, que fica a } \\
\text { cargo do DEFE. }\end{array}$ \\
\hline $\begin{array}{l}22 \text { de } \\
\text { fevereiro } \\
\text { de } 1968\end{array}$ & $\begin{array}{l}\text { Governo do } \\
\text { Estado de } \\
\text { São Paulo }\end{array}$ & & Homenagem & & $\begin{array}{l}\text { Entrega do Troféu } \\
\text { Abreu Sodré aos } \\
\text { dirigentes do XV } \\
\text { de Piracicaba, } \\
\text { campeão da } \\
\text { primeira divisão em } \\
67 .\end{array}$ \\
\hline $\begin{array}{l}08 \text { de } \\
\text { março } \\
\text { de } 1968\end{array}$ & $\begin{array}{l}\text { Governo do } \\
\text { Estado de } \\
\text { São Paulo }\end{array}$ & & Homenagem & & \begin{tabular}{|l|} 
Governador \\
entrega Medalha \\
do Estado ao \\
campeão mundial \\
de natação José \\
Silvio Fiolo. \\
Presente na \\
solenidade \\
presidente da \\
Federação Paulista \\
de Natação. \\
\end{tabular} \\
\hline $\begin{array}{l}08 \text { de } \\
\text { março } \\
\text { de } 1968\end{array}$ & $\begin{array}{l}\text { Câmara } \\
\text { Municipal de } \\
\text { São Paulo }\end{array}$ & $\begin{array}{l}\text { Pronunciamen } \\
\text { to }\end{array}$ & Ao executivo & & $\begin{array}{l}\text { Vereador Alfredo } \\
\text { Monetti fala do } \\
\text { esporte amador e } \\
\text { faz apelo ao } \\
\text { Prefeito Faria Lima } \\
\text { para criar o } \\
\text { "Palácio do } \\
\text { Esporte Amador", } \\
\text { na sede da antiga } \\
\text { Assembleia. }\end{array}$ \\
\hline $\begin{array}{l}15 \text { de } \\
\text { março } \\
\text { de } 1968\end{array}$ & $\begin{array}{l}\text { Câmara } \\
\text { Municipal de } \\
\text { São Paulo }\end{array}$ & $\begin{array}{l}\text { Pronunciamen } \\
\text { to }\end{array}$ & Discussão & & $\begin{array}{l}\text { Vereador } \\
\text { Francisco Batista } \\
\text { fala sobre o } \\
\text { "Comércio imoral e } \\
\text { extravagante dos } \\
\text { bilhetes de loteria". } \\
\text { Vereador Benedito } \\
\text { Rocha fala da falta } \\
\text { de prestação de } \\
\text { contas da Caixa. }\end{array}$ \\
\hline $\begin{array}{l}21 \text { de } \\
\text { março } \\
\text { de } 1968\end{array}$ & $\begin{array}{l}\text { Assembleia } \\
\text { Legislativa } \\
\text { de São } \\
\text { Paulo }\end{array}$ & Projeto de Lei & Parecer & 84 & $\begin{array}{l}\text { Parecer favorável } \\
\text { ao projeto de lei } \\
\text { que visa } \\
\text { homenagear o } \\
\text { jornalista Gavino } \\
\text { Virdes - post } \\
\text { mortem. }\end{array}$ \\
\hline $\begin{array}{l}27 \text { de } \\
\text { março } \\
\text { de } 1968\end{array}$ & $\begin{array}{l}\text { Câmara } \\
\text { Municipal de } \\
\text { São Paulo }\end{array}$ & $\begin{array}{l}\text { Pronunciamen } \\
\text { to }\end{array}$ & Discussão & & \begin{tabular}{|l} 
Vereador Tabajara \\
Vidigal Leitão fala \\
sobre a \\
importância do \\
Pacaembu e sobre \\
estudo para \\
ampliação - cobra
\end{tabular} \\
\hline
\end{tabular}




\begin{tabular}{|c|c|c|c|c|}
\hline & & & & $\begin{array}{l}\text { do poder Executivo } \\
\text { abertura de } \\
\text { licitação para a } \\
\text { obra. Prazo de } 21 \\
\text { dias. }\end{array}$ \\
\hline $\begin{array}{l}30 \text { de } \\
\text { março } \\
\text { de } 1968\end{array}$ & $\begin{array}{l}\text { Governo do } \\
\text { Estado de } \\
\text { São Paulo } \\
\end{array}$ & Projeto de Lei & Ao Legislativo & \begin{tabular}{|l} 
Apresentado pelo \\
governo Abreu \\
Sodré projeto de lei \\
para apreciação da \\
Alesp que cria \\
Fundo de Melhoria \\
das Estancias na \\
Secretaria de \\
Cultura, Esporte e \\
Turismo. Alesp tem \\
40 para responder.
\end{tabular} \\
\hline $\begin{array}{l}04 \text { de } \\
\text { abril de } \\
1968\end{array}$ & $\begin{array}{l}\text { Governo do } \\
\text { Estado de } \\
\text { São Paulo }\end{array}$ & Ato Executivo & Publicidade & \begin{tabular}{|l} 
Secretaria de \\
Cultura, Esporte e \\
Turismo começa \\
obra de construção \\
de camping em \\
Campos do Jordão \\
após firmado \\
convênio com a \\
Prefeitura. \\
\end{tabular} \\
\hline $\begin{array}{l}05 \text { de } \\
\text { abril de } \\
1968\end{array}$ & $\begin{array}{l}\text { Assembleia } \\
\text { Legislativa } \\
\text { de São } \\
\text { Paulo }\end{array}$ & $\begin{array}{l}\text { Pronunciamen } \\
\text { to }\end{array}$ & Discussão & $\begin{array}{l}\text { Discussão na } \\
\text { Alesp sobre a } \\
\text { unificação da } \\
\text { Companhia } \\
\text { Paulista Férrea e a } \\
\text { Estrada Férrea } \\
\text { Araraquarense. } \\
\text { Deputado Santos } \\
\text { Ferreira se diz } \\
\text { contrário tanto a } \\
\text { unificação quanto a } \\
\text { indicação do Sr. } \\
\text { Domingues Luz } \\
\text { Faria para a } \\
\text { direção. Deputado } \\
\text { Roberto Gihara sai } \\
\text { em defesa de } \\
\text { Domingues, a } \\
\text { quem chama de } \\
\text { "Doutor", diz que } \\
\text { como dirigente } \\
\text { esporte este } \\
\text { aprendeu a gerir e } \\
\text { o compara a Laudo } \\
\text { Natel. }\end{array}$ \\
\hline $\begin{array}{l}20 \text { de } \\
\text { abril de } \\
1968\end{array}$ & $\begin{array}{l}\text { Governo do } \\
\text { Estado de } \\
\text { São Paulo }\end{array}$ & Ato Executivo & $\begin{array}{l}\text { Liberação de } \\
\text { recursos }\end{array}$ & $\begin{array}{l}\text { Governo libera } \\
\text { verbas para } \\
\text { conjunto esportivo } \\
\text { no lbirapuera, } \\
\text { previsão de } \\
\text { inauguração em } 9 \\
\text { de julho. }\end{array}$ \\
\hline $\begin{array}{l}23 \text { de } \\
\text { abril de } \\
1968\end{array}$ & \begin{tabular}{|l} 
Câmara \\
Municipal de \\
São Paulo
\end{tabular} & $\begin{array}{l}\text { Pronunciamen } \\
\text { to }\end{array}$ & Discussão & $\begin{array}{l}\text { Vereador João } \\
\text { Lemos pede auxílio } \\
\text { do Prefeito para }\end{array}$ \\
\hline
\end{tabular}




\begin{tabular}{|c|c|c|c|c|c|}
\hline & & & & & $\begin{array}{l}\text { estrutura do } \\
\text { esporte amador na } \\
\text { cidade. }\end{array}$ \\
\hline $\begin{array}{l}23 \text { de } \\
\text { abril de } \\
1968 \\
\end{array}$ & \begin{tabular}{|l} 
Câmara \\
Municipal de \\
São Paulo \\
\end{tabular} & Requerimento & Ao executivo & 1969-68 & $\begin{array}{l}\text { Pedido ao prefeito } \\
\text { para } \\
\text { desapropriação de } \\
\text { área para pátio } \\
\text { esportivo. }\end{array}$ \\
\hline $\begin{array}{l}24 \text { de } \\
\text { abril de } \\
1968 \\
\end{array}$ & \begin{tabular}{|l} 
Governo do \\
Estado de \\
São Paulo \\
\end{tabular} & Ato Executivo & Portaria & 2 & $\begin{array}{l}\text { Dispõe sobre o } \\
\text { regulamento dos } \\
\text { jogos abertos do } \\
\text { Interior. }\end{array}$ \\
\hline $\begin{array}{l}01 \text { de } \\
\text { maio de } \\
1968\end{array}$ & $\begin{array}{l}\text { Assembleia } \\
\text { Legislativa } \\
\text { de São } \\
\text { Paulo }\end{array}$ & $\begin{array}{l}\text { Pronunciamen } \\
\text { to }\end{array}$ & Homenagem & & $\begin{array}{l}\text { Congratulações } \\
\text { formais a Casper } \\
\text { Líbero pelas } \\
\text { revistas Gazeta e } \\
\text { Gazeta Esportiva. }\end{array}$ \\
\hline \begin{tabular}{|l}
03 de \\
maio de \\
1968 \\
\end{tabular} & \begin{tabular}{|l|} 
Governo do \\
Estado de \\
São Paulo \\
\end{tabular} & Ato Executivo & Portaria & $167 / 68$ & $\begin{array}{l}\text { Regulamento dos } \\
\text { Jogos Abertos do } \\
\text { Interior. }\end{array}$ \\
\hline $\begin{array}{l}11 \text { de } \\
\text { maios } \\
\text { de } 1968\end{array}$ & $\begin{array}{l}\text { Câmara } \\
\text { Municipal de } \\
\text { São Paulo } \\
\end{array}$ & Requerimento & Ao executivo & $1563 / 68$ & $\begin{array}{l}\text { Pedido ao prefeito } \\
\text { para construção de } \\
\text { ponte maior entre o } \\
\text { Tatuapé e a Vila } \\
\text { Maria para atender } \\
\text { sobretudo os } \\
\text { torcedores e } \\
\text { frequentadores do } \\
\text { Corinthians. }\end{array}$ \\
\hline $\begin{array}{l}24 \text { de } \\
\text { maio de } \\
1968 \\
\end{array}$ & $\begin{array}{l}\text { Assembleia } \\
\text { Legislativa } \\
\text { de São } \\
\text { Paulo } \\
\end{array}$ & Moção & Ao executivo & $42 / 68$ & $\begin{array}{l}\text { Pede-se a criação } \\
\text { de imposto de 5\% } \\
\text { sobre os lucros dos } \\
\text { times profissionais } \\
\text { para que seja } \\
\text { aplicado no } \\
\text { esporte amador } \\
\text { enquanto não se } \\
\text { regulariza a Loteria } \\
\text { do Estado. } \\
\end{array}$ \\
\hline $\begin{array}{l}30 \text { de } \\
\text { maio de } \\
1968\end{array}$ & $\begin{array}{l}\text { Assembleia } \\
\text { Legislativa } \\
\text { de São } \\
\text { Paulo }\end{array}$ & $\begin{array}{l}\text { Pronunciamen } \\
\text { to }\end{array}$ & Nota de Pesar & & $\begin{array}{l}\text { Nota de pesar } \\
\text { oficial sobre a } \\
\text { morte de Manoel } \\
\text { do P., ex- } \\
\text { presidente do } 15 \\
\text { de Novembro. }\end{array}$ \\
\hline $\begin{array}{l}30 \text { de } \\
\text { maio de } \\
1968\end{array}$ & $\begin{array}{l}\text { Assembleia } \\
\text { Legislativa } \\
\text { de São } \\
\text { Paulo } \\
\end{array}$ & Moção & Ao executivo & $42 / 68$ & $\begin{array}{l}\text { Deputado Avallone } \\
\text { Junior faz apelo ao } \\
\text { presidente da } \\
\text { República para que } \\
\text { formalize o imposto } \\
\text { de } 5 \% \text {. }\end{array}$ \\
\hline $\begin{array}{l}31 \text { de } \\
\text { maio de } \\
1968\end{array}$ & $\begin{array}{l}\text { Assembleia } \\
\text { Legislativa } \\
\text { de São } \\
\text { Paulo }\end{array}$ & Parecer & & 11 & $\begin{array}{l}\text { parecer favorável a } \\
\text { concessão do título } \\
\text { de "Cidadão } \\
\text { Emérito" ao Sr. } \\
\text { Constantino Cury, } \\
\text { presidente do } \\
\text { Esporte Clube } \\
\text { Sírio. }\end{array}$ \\
\hline
\end{tabular}




\begin{tabular}{|c|c|c|c|c|c|}
\hline $\begin{array}{l}31 \text { de } \\
\text { maio de } \\
1968\end{array}$ & $\begin{array}{l}\text { Governo do } \\
\text { Estado de } \\
\text { São Paulo } \\
\end{array}$ & Ato Executivo & Publicidade & Comissão & \begin{tabular}{|l} 
Pronto o \\
anteprojeto que \\
reforma o sistema \\
estadual de \\
esporte.
\end{tabular} \\
\hline $\begin{array}{l}04 \text { de } \\
\text { junho de } \\
1968\end{array}$ & $\begin{array}{l}\text { Câmara } \\
\text { Municipal de } \\
\text { São Paulo }\end{array}$ & $\begin{array}{l}\text { Pronunciamen } \\
\text { to }\end{array}$ & Discussão & & $\begin{array}{l}\text { Vereador Pereira } \\
\text { Barreto critica o } \\
\text { prefeito Faria Lima } \\
\text { pelo projeto de } \\
\text { criação de parque } \\
\text { em Interlagos } \\
\text { alegando o } \\
\text { simbolismo desse } \\
\text { espaço para o } \\
\text { automobilismo. }\end{array}$ \\
\hline $\begin{array}{l}07 \text { de } \\
\text { junho de } \\
1968\end{array}$ & $\begin{array}{l}\text { Governo do } \\
\text { Estado de } \\
\text { São Paulo } \\
\end{array}$ & Ato Executivo & autorização & $\begin{array}{l}\text { Secretaria de } \\
\text { Obras Públicas }\end{array}$ & $\begin{array}{l}\text { Despacho do } \\
\text { governador } \\
\text { autorizando a } \\
\text { contratação da } \\
\text { empresa } \\
\text { Construtora Dumes } \\
\text { AS para a } \\
\text { conclusão do } \\
\text { velódromo do } \\
\text { lbirapuera. } \\
\end{array}$ \\
\hline $\begin{array}{l}18 \text { de } \\
\text { junho de } \\
1968\end{array}$ & $\begin{array}{l}\text { Assembleia } \\
\text { Legislativa } \\
\text { de São } \\
\text { Paulo } \\
\end{array}$ & $\begin{array}{l}\text { Pronunciamen } \\
\text { to }\end{array}$ & Ao executivo & & $\begin{array}{l}\text { Deputado Osvaldo } \\
\text { Massei pede } \\
\text { construção de } \\
\text { novo estádio } \\
\text { municipal em São } \\
\text { Paulo alegando } \\
\text { que o Pacaembu } \\
\text { não mais comporta } \\
\text { a demanda da } \\
\text { cidade. } \\
\end{array}$ \\
\hline $\begin{array}{l}19 \text { de } \\
\text { junho de } \\
1968\end{array}$ & $\begin{array}{l}\text { Câmara } \\
\text { Municipal de } \\
\text { São Paulo }\end{array}$ & $\begin{array}{l}\text { Pronunciamen } \\
\text { to }\end{array}$ & Ao executivo & & $\begin{array}{l}\text { vereador Monteiro } \\
\text { Carvalho cobra } \\
\text { construção de } \\
\text { praça de esportes } \\
\text { na Lapa, alegando } \\
\text { que existe um } \\
\text { terreno para isso } \\
\text { doado a anos pela } \\
\text { Compert City. } \\
\end{array}$ \\
\hline $\begin{array}{l}20 \text { de } \\
\text { junho de } \\
1968\end{array}$ & $\begin{array}{l}\text { Câmara } \\
\text { Municipal de } \\
\text { São Paulo }\end{array}$ & $\begin{array}{l}\text { Pronunciamen } \\
\text { to }\end{array}$ & Indicação & $s / n$ & $\begin{array}{l}\text { Indicação de } \\
\text { construção em } \\
\text { caráter prioritário } \\
\text { de estádio distrital } \\
\text { na Lapa. }\end{array}$ \\
\hline $\begin{array}{l}28 \text { de } \\
\text { junho de } \\
1968\end{array}$ & $\begin{array}{l}\text { Assembleia } \\
\text { Legislativa } \\
\text { de São } \\
\text { Paulo }\end{array}$ & $\begin{array}{l}\text { Pronunciamen } \\
\text { to }\end{array}$ & Discussão & & $\begin{array}{l}\text { Debate na Alesp } \\
\text { sobre a falta de } \\
\text { entrosamento entre } \\
\text { o DEFE e a Escola } \\
\text { Estadual de } \\
\text { Educação Física. }\end{array}$ \\
\hline $\begin{array}{l}28 \text { de } \\
\text { junho de } \\
1968\end{array}$ & $\begin{array}{l}\text { Assembleia } \\
\text { Legislativa } \\
\text { de São } \\
\text { Paulo } \\
\end{array}$ & $\mathrm{CPI}$ & Reunião & & $\begin{array}{l}\text { Primeira reunião } \\
\text { na Ales da CPI } \\
\text { sobre a Escola } \\
\text { Estadual de } \\
\text { Educação Física. }\end{array}$ \\
\hline
\end{tabular}




\begin{tabular}{|c|c|c|c|c|c|}
\hline \begin{tabular}{|l}
03 de \\
junho de \\
1968 \\
\end{tabular} & $\begin{array}{l}\text { Câmara } \\
\text { Municipal de } \\
\text { São Paulo } \\
\end{array}$ & $\begin{array}{l}\text { Pronunciamen } \\
\text { to }\end{array}$ & & & $\begin{array}{l}\text { Vereador Monteiro } \\
\text { carvalho cobra do } \\
\text { DEFE fiscalização } \\
\text { das piscinas } \\
\text { públicas. }\end{array}$ \\
\hline \begin{tabular}{|l}
09 de \\
junho de \\
1968 \\
\end{tabular} & $\begin{array}{l}\text { Governo do } \\
\text { Estado de } \\
\text { São Paulo } \\
\end{array}$ & Ato Executivo & Inauguração & & $\begin{array}{l}\text { Inauguração do } \\
\text { Conjunto Esportivo } \\
\text { do lbirapuera por } \\
\text { Abreu Sodré - o } \\
\text { maior da América } \\
\text { Latina até então. } \\
\end{array}$ \\
\hline $\begin{array}{l}20 \text { de } \\
\text { junho de } \\
1968 \\
\end{array}$ & $\begin{array}{l}\text { Prefeitura de } \\
\text { gardênia }\end{array}$ & Ato Executivo & desapropriação & & $\begin{array}{l}\text { Desapropriação de } \\
\text { terreno para } \\
\text { construção de } \\
\text { praça de esportes. }\end{array}$ \\
\hline $\begin{array}{l}03 \text { de } \\
\text { agosto } \\
\text { de } 1968 \\
\end{array}$ & $\begin{array}{l}\text { Governo do } \\
\text { Estado de } \\
\text { São Paulo } \\
\end{array}$ & Projeto de Lei & Veto Parcial & $\begin{array}{l}\text { PL 92/68, msg } \\
168\end{array}$ & $\begin{array}{l}\text { Govenador veta a } \\
\text { cláusula que dá à } \\
\text { Associação dos } \\
\text { Municípios o } \\
\text { Conselho do } \\
\text { Fundo das } \\
\text { Estâncias. }\end{array}$ \\
\hline $\begin{array}{l}08 \text { de } \\
\text { agosto } \\
\text { de } 1968 \\
\end{array}$ & $\begin{array}{l}\text { Assembleia } \\
\text { Legislativa } \\
\text { de São } \\
\text { Paulo } \\
\end{array}$ & $\begin{array}{l}\text { Pronunciamen } \\
\text { to }\end{array}$ & Discussão & & $\begin{array}{l}\text { Durante votação } \\
\text { do código de } \\
\text { educação do } \\
\text { estado, o deputado } \\
\text { Orlando Jurca faz } \\
\text { duras críticas ao } \\
\text { governador que } \\
\text { segundo ele faz } \\
\text { autopromoção da } \\
\text { pauta e usa } \\
\text { erroneamente a } \\
\text { imagem de Pelé } \\
\text { "moço puro que } \\
\text { nunca deveria ser } \\
\text { envolvido em } \\
\text { política". } \\
\end{array}$ \\
\hline $\begin{array}{l}23 \text { de } \\
\text { agosto } \\
\text { de } 1968\end{array}$ & $\begin{array}{l}\text { Governo do } \\
\text { Estado de } \\
\text { São Paulo } \\
\end{array}$ & Ato Executivo & Decreto & 50208 & $\begin{array}{l}\text { Inclui no calendário } \\
\text { oficial da cidade a } \\
\text { prova esportiva } \\
\text { denominada " Mil } \\
\text { milhas ciclísticas } \\
\text { brasileiras". } \\
\end{array}$ \\
\hline \begin{tabular}{|l|}
24 de \\
agosto \\
de 1968 \\
\end{tabular} & \begin{tabular}{|l|} 
Câmara \\
Municipal de \\
São Paulo \\
\end{tabular} & $\begin{array}{l}\text { Pronunciamen } \\
\text { to }\end{array}$ & Homenagem & & $\begin{array}{l}\text { Voto de júbilo ao } \\
\text { Esporte Clube } \\
\text { Sírio. } \\
\end{array}$ \\
\hline $\begin{array}{l}30 \text { de } \\
\text { agosto } \\
\text { de } 1968\end{array}$ & $\begin{array}{l}\text { Câmara } \\
\text { Municipal de } \\
\text { São Paulo }\end{array}$ & $\begin{array}{l}\text { Pronunciamen } \\
\text { to }\end{array}$ & Discussão & & $\begin{array}{l}\text { Vereador Alfredo } \\
\text { Monetti fala da } \\
\text { vitória do C.A. } \\
\text { Parque da Mooca. }\end{array}$ \\
\hline $\begin{array}{l}03 \text { de } \\
\text { setembr } \\
\text { o de } \\
1968 \\
\end{array}$ & $\begin{array}{l}\text { Governo do } \\
\text { Estado de } \\
\text { São Paulo } \\
\end{array}$ & Ato Executivo & Inauguração & & \begin{tabular}{|l} 
Inauguração do \\
Conjunto Esportivo \\
Constâncio Vaz \\
Guimarães (dentro \\
do lbirapuera). \\
\end{tabular} \\
\hline \begin{tabular}{|l|}
07 de \\
setembr \\
o de \\
1968 \\
\end{tabular} & $\begin{array}{l}\text { Governo do } \\
\text { Estado de } \\
\text { São Paulo } \\
\end{array}$ & Ato Executivo & $\begin{array}{l}\text { Prorrogação de } \\
\text { Prazo }\end{array}$ & & $\begin{array}{l}\text { Governo prorroga } \\
\text { prazo para a } \\
\text { empresa Dumes } \\
\text { AS por } 60 \text { dia para }\end{array}$ \\
\hline
\end{tabular}




\begin{tabular}{|c|c|c|c|c|c|}
\hline & & & & & $\begin{array}{l}\text { a entrega da } \\
\text { piscina, } \\
\text { arquibancada e } \\
\text { vestiário no } \\
\text { complexo do } \\
\text { lbirapuera. }\end{array}$ \\
\hline $\begin{array}{l}11 \text { de } \\
\text { setembr } \\
\text { o de } \\
1968 \\
\end{array}$ & $\begin{array}{l}\text { Assembleia } \\
\text { Legislativa } \\
\text { de São } \\
\text { Paulo } \\
\end{array}$ & $\begin{array}{l}\text { Pronunciamen } \\
\text { to }\end{array}$ & Discussão & & $\begin{array}{l}\text { Deputado Wadih } \\
\text { Helu enaltece a } \\
\text { memória de } \\
\text { Constâncio } \\
\text { Guimarães Vaz e } \\
\text { fala bem da } \\
\text { decisão de dar seu } \\
\text { nome ao Complexo } \\
\text { no lbirapuera. }\end{array}$ \\
\hline $\begin{array}{l}12 \text { de } \\
\text { setembr } \\
0 \text { de } \\
1968\end{array}$ & $\begin{array}{l}\text { Assembleia } \\
\text { Legislativa } \\
\text { de São } \\
\text { Paulo }\end{array}$ & $\begin{array}{l}\text { Pronunciamen } \\
\text { to }\end{array}$ & Nota de Pesar & & $\begin{array}{l}\text { Nota de pesar pela } \\
\text { morte de Mario } \\
\text { Tabanatti, diretor } \\
\text { do Esporte Clube } \\
\text { Igarapava. }\end{array}$ \\
\hline $\begin{array}{l}18 \text { de } \\
\text { setembr } \\
0 \text { de } \\
1968\end{array}$ & $\begin{array}{l}\text { Assembleia } \\
\text { Legislativa } \\
\text { de São } \\
\text { Paulo }\end{array}$ & $\begin{array}{l}\text { Pronunciamen } \\
\text { to }\end{array}$ & Homenagem & & $\begin{array}{l}\text { Nota de júbilo a } \\
\text { empresa Industria } \\
\text { e Comércio de } \\
\text { Bicicletas Caloi AS } \\
\text { e ao Diário Popular } \\
\text { pela realização das } \\
\text { Mil Milhas. }\end{array}$ \\
\hline $\begin{array}{l}18 \text { de } \\
\text { setembr } \\
\text { o de } \\
1968\end{array}$ & $\begin{array}{l}\text { Câmara } \\
\text { Municipal de } \\
\text { São Paulo }\end{array}$ & $\begin{array}{l}\text { Pronunciamen } \\
\text { to }\end{array}$ & Discussão & & $\begin{array}{l}\text { Vereador Américo } \\
\text { Sugau fala em } \\
\text { favor das } \\
\text { associações de } \\
\text { judô reprovando a } \\
\text { possibilidade de as } \\
\text { academias } \\
\text { passarem a ter de } \\
\text { pagar taxas para a } \\
\text { prefeitura. }\end{array}$ \\
\hline $\begin{array}{l}18 \text { de } \\
\text { setembr } \\
\text { o de } \\
1968 \\
\end{array}$ & $\begin{array}{l}\text { Assembleia } \\
\text { Legislativa } \\
\text { de São } \\
\text { Paulo } \\
\end{array}$ & $\begin{array}{l}\text { Projeto de } \\
\text { Resolução }\end{array}$ & & 9 & $\begin{array}{l}\text { Projeto para } \\
\text { conceder Medalha } \\
\text { do Mérito Paulista } \\
\text { ao vencedor do } \\
\text { concurso } \\
\text { Operação } \\
\text { bandeirante como } \\
\text { forma de } \\
\text { reconhecimento do } \\
\text { esporte amador. }\end{array}$ \\
\hline $\begin{array}{l}25 \text { de } \\
\text { setembr } \\
\text { o de } \\
1968\end{array}$ & $\begin{array}{l}\text { Câmara } \\
\text { Municipal de } \\
\text { São Paulo }\end{array}$ & $\begin{array}{l}\text { Pronunciamen } \\
\text { to }\end{array}$ & Discussão & & $\begin{array}{l}\text { Vereador Sander } \\
\text { Fichman reclama } \\
\text { ao prefeito dos } \\
\text { altos preços dos } \\
\text { ingressos para } \\
\text { assistir "o jogo das } \\
\text { multidões". }\end{array}$ \\
\hline \begin{tabular}{|l}
28 de \\
setembr \\
o de \\
1968 \\
\end{tabular} & $\begin{array}{l}\text { Assembleia } \\
\text { Legislativa } \\
\text { de São } \\
\text { Paulo } \\
\end{array}$ & $\begin{array}{l}\text { Pronunciamen } \\
\text { to }\end{array}$ & Homenagem & & $\begin{array}{l}\text { Voto de júbilo do } \\
\text { deputado Wadih } \\
\text { Helu pelos } 15 \text { anos } \\
\text { do Canal } 7 .\end{array}$ \\
\hline
\end{tabular}




\begin{tabular}{|c|c|c|c|c|c|}
\hline $\begin{array}{l}02 \text { de } \\
\text { outubro } \\
\text { de } 1968\end{array}$ & $\begin{array}{l}\text { Governo do } \\
\text { Estado de } \\
\text { São Paulo }\end{array}$ & Ato Executivo & Decreto & 59461 & $\begin{array}{l}\text { Autoria a } \\
\text { contratação de } \\
\text { pessoal para atar } \\
\text { na no Conjunto } \\
\text { Esportivo } \\
\text { Constâncio Vaz } \\
\text { Guimarães - } 2 \\
\text { médicos e } 1 \\
\text { supervisor técnico. }\end{array}$ \\
\hline $\begin{array}{l}03 \text { de } \\
\text { outubro } \\
\text { de } 1968 \\
\end{array}$ & $\begin{array}{l}\text { Assembleia } \\
\text { Legislativa } \\
\text { de São } \\
\text { Paulo } \\
\end{array}$ & $\begin{array}{l}\text { Pronunciamen } \\
\text { to }\end{array}$ & Homenagem & & $\begin{array}{l}\text { Deputado Wadih } \\
\text { Helu faz voto de } \\
\text { congratulações à } \\
\text { Ealobrás -Editora } \\
\text { Documentação } \\
\text { Brasileira pela obra } \\
\text { "História llustrada } \\
\text { do Futebol } \\
\text { Brasileiro". } \\
\end{array}$ \\
\hline $\begin{array}{l}04 \text { de } \\
\text { outubro } \\
\text { de } 1968 \\
\end{array}$ & $\begin{array}{l}\text { Câmara } \\
\text { Municipal de } \\
\text { São Paulo } \\
\end{array}$ & $\begin{array}{l}\text { Pronunciamen } \\
\text { to }\end{array}$ & Discussão & & \begin{tabular}{|l|} 
Vereador João \\
Lemos reclama do \\
"estado de \\
abandono do \\
Pacaembu". \\
\end{tabular} \\
\hline $\begin{array}{l}04 \text { de } \\
\text { outubro } \\
\text { de } 1968\end{array}$ & $\begin{array}{l}\text { Governo do } \\
\text { Estado de } \\
\text { São Paulo }\end{array}$ & Ato Executivo & $\begin{array}{l}\text { Liberação de } \\
\text { recursos }\end{array}$ & & $\begin{array}{l}\text { Departamento de } \\
\text { obras abre } \\
\text { concorrência para } \\
\text { construção de } \\
\text { quadra de esportes } \\
\text { na penitenciária de } \\
\text { Avaré. }\end{array}$ \\
\hline \begin{tabular}{|l|}
25 de \\
outubro \\
de 1968 \\
\end{tabular} & $\begin{array}{l}\text { Governo do } \\
\text { Estado de } \\
\text { São Paulo } \\
\end{array}$ & Ato Executivo & Decreto & 585 & \\
\hline $\begin{array}{l}07 \text { de } \\
\text { novembr } \\
\text { o de } \\
1968 \\
\end{array}$ & $\begin{array}{l}\text { Assembleia } \\
\text { Legislativa } \\
\text { de São } \\
\text { Paulo } \\
\end{array}$ & $\begin{array}{l}\text { Pronunciamen } \\
\text { to }\end{array}$ & Discussão & & $\begin{array}{l}\text { Deputado Valério } \\
\text { Giuli fala do mau } \\
\text { desempenho do } \\
\text { Brasil nas } \\
\text { Olimpíadas e cobra } \\
\text { atitude do poder } \\
\text { público. }\end{array}$ \\
\hline $\begin{array}{l}19 \text { de } \\
\text { novembr } \\
\text { o de } \\
1968\end{array}$ & $\begin{array}{l}\text { Governo do } \\
\text { Estado de } \\
\text { São Paulo }\end{array}$ & Ato Executivo & Publicidade & Contrato & $\begin{array}{l}\text { Publica-se resumo } \\
\text { do contrato feito } \\
\text { entre o governo do } \\
\text { estado e a Casper } \\
\text { Líbero para } \\
\text { organizar através a } \\
\text { Gazeta Esportiva } \\
\text { torneios de } \\
\text { diversas } \\
\text { modalidades de } \\
\text { esporte. }\end{array}$ \\
\hline \begin{tabular}{|l|}
20 de \\
novembr \\
o de \\
1968 \\
\end{tabular} & \begin{tabular}{|l} 
Assembleia \\
Legislativa \\
de São \\
Paulo \\
\end{tabular} & CPI & Publicidade & Ata III reunião & $\begin{array}{l}\text { Ata da terceira } \\
\text { reunião da CPI da } \\
\text { Escola Estadual de } \\
\text { Educação Física. }\end{array}$ \\
\hline $\begin{array}{l}03 \text { de } \\
\text { dezembr } \\
\text { o de } \\
1968\end{array}$ & $\begin{array}{l}\text { Câmara } \\
\text { Municipal de } \\
\text { São Paulo }\end{array}$ & Indicação & Ao executivo & $1934 / 68$ & $\begin{array}{l}\text { Indicação ao } \\
\text { prefeito para } \\
\text { criação de linha de } \\
\text { ônibus que fosse } \\
\text { da Cidade }\end{array}$ \\
\hline
\end{tabular}




\begin{tabular}{|c|c|c|c|c|c|}
\hline & & & & & \begin{tabular}{|l} 
Universitária ao \\
Parque São Jorge \\
para atender os \\
moradores de \\
Pinheiros \\
torcedores do \\
Corinthians. \\
\end{tabular} \\
\hline $\begin{array}{l}03 \text { de } \\
\text { dezembr } \\
\text { o de } \\
1968\end{array}$ & \begin{tabular}{|l} 
Câmara \\
Municipal de \\
São Paulo \\
\end{tabular} & $\begin{array}{l}\text { Pronunciamen } \\
\text { to }\end{array}$ & Ao executivo & & $\begin{array}{l}\text { Vereador Osvaldo } \\
\text { Giraldes fala sobre } \\
\text { mensagem do } \\
\text { prefeito enviada } \\
\text { junto com o projeto } \\
\text { de lei que concede } \\
\text { ao Corinthians } \\
\text { terreno por } 40 \\
\text { anos. Aproveita o } \\
\text { ensejo para cobrar } \\
\text { construção de } \\
\text { estádios distritais } \\
\text { na cidade. } \\
\end{array}$ \\
\hline $\begin{array}{l}11 \text { de } \\
\text { dezembr } \\
\text { o de } \\
1968\end{array}$ & $\begin{array}{l}\text { Governo do } \\
\text { Estado de } \\
\text { São Paulo } \\
\end{array}$ & Ato Executivo & DEFE & ato 9 & \begin{tabular}{|l|} 
Cria-se inspetoria \\
regional de \\
esportes ligada ao \\
DEFE em Barretos.
\end{tabular} \\
\hline $\begin{array}{l}14 \text { de } \\
\text { dezembr } \\
\text { o de } \\
1968\end{array}$ & $\begin{array}{l}\text { Assembleia } \\
\text { Legislativa } \\
\text { de São } \\
\text { Paulo } \\
\end{array}$ & Projeto de Lei & Do executivo & 652/68 & $\begin{array}{l}\text { Apresentação do } \\
\text { PL, junto com a } \\
\text { mensagem } 312 / 38 \\
\text { do governador do } \\
\text { estado, que dispõe } \\
\text { sobre o Sistema } \\
\text { Estadual de } \\
\text { Desporto, em } \\
\text { cumprimento do } \\
\text { artigo } 127 \text { da } \\
\text { constituição do } \\
\text { estado. }\end{array}$ \\
\hline $\begin{array}{l}19 \text { de } \\
\text { dezembr } \\
\text { o de } \\
1968\end{array}$ & \begin{tabular}{|l} 
Assembleia \\
Legislativa \\
de São \\
Paulo \\
\end{tabular} & $\begin{array}{l}\text { Pronunciamen } \\
\text { to }\end{array}$ & Discussão & & $\begin{array}{l}\text { Deputado Avallone } \\
\text { Junior fala da falta } \\
\text { de apoio do } \\
\text { governo para o } \\
\text { esporte e pede } \\
\text { novamente a } \\
\text { criação do imposto } \\
\text { de } 5 \% \text { sobre as } \\
\text { rendas das } \\
\text { competições dos } \\
\text { times profissionais } \\
\text { para aplicação no } \\
\text { esporte amador } \\
\text { enquanto não se } \\
\text { cria a loteria } \\
\text { esportiva nacional. }\end{array}$ \\
\hline $\begin{array}{l}24 \text { de } \\
\text { dezembr } \\
\text { o de } \\
1968\end{array}$ & $\begin{array}{l}\text { Governo do } \\
\text { Estado de } \\
\text { São Paulo }\end{array}$ & Ato Executivo & Publicidade & Contrato & \begin{tabular}{|l|} 
Termo de \\
ratificação e \\
retificação de \\
contrato do \\
governo com \\
Construtora Itápolis \\
LTDA para a \\
\end{tabular} \\
\hline
\end{tabular}




\begin{tabular}{|c|c|c|c|c|c|}
\hline & & & & & $\begin{array}{l}\text { construção de } \\
\text { balneário em lbirá. }\end{array}$ \\
\hline $\begin{array}{l}25 \text { de } \\
\text { dezembr } \\
\text { o de } \\
1968 \\
\end{array}$ & $\begin{array}{l}\text { Câmara } \\
\text { Municipal de } \\
\text { São Paulo }\end{array}$ & $\begin{array}{l}\text { Pronunciamen } \\
\text { to }\end{array}$ & Homenagem & & \begin{tabular}{|l} 
Voto de \\
congratulações à \\
Ealobrás -Editora \\
Documentação \\
Brasileira pela obra \\
"História llustrada \\
do Futebol \\
Brasileiro".
\end{tabular} \\
\hline $\begin{array}{l}31 \text { de } \\
\text { dezembr } \\
\text { o de } \\
1968 \\
\end{array}$ & $\begin{array}{l}\text { Governo do } \\
\text { Estado de } \\
\text { São Paulo } \\
\end{array}$ & Ato Executivo & Concessão & & $\begin{array}{l}\text { Concede a Sylvio } \\
\text { Padilha sexta parte } \\
\text { de aposentadoria. }\end{array}$ \\
\hline $\begin{array}{l}08 \text { de } \\
\text { fevereiro } \\
\text { de } 1969 \\
\end{array}$ & $\begin{array}{l}\text { Tribunal de } \\
\text { Contas }\end{array}$ & Ato Executivo & Publicidade & contrato 656 & $\begin{array}{l}\text { Publicização de } \\
\text { extrato de contrato } \\
\text { com a Casper } \\
\text { Líbero para } \\
\text { organização de } \\
\text { torneios de } \\
\text { diversas } \\
\text { modalidades } \\
\text { esportivas através } \\
\text { da Gazeta } \\
\text { Esportiva, e } \\
\text { publicidade em } \\
\text { veículos de mídia. } \\
\end{array}$ \\
\hline $\begin{array}{l}27 \text { de } \\
\text { fevereiro } \\
\text { de } 1969 \\
\end{array}$ & $\begin{array}{l}\text { Governo do } \\
\text { Estado de } \\
\text { São Paulo }\end{array}$ & Ato Executivo & Publicidade & & $\begin{array}{l}\text { Melhoramento } \\
\text { concluído na } \\
\text { acústica do } \\
\text { Ginásio do } \\
\text { lbirapuera. }\end{array}$ \\
\hline $\begin{array}{l}07 \text { de } \\
\text { março } \\
\text { de } 1969 \\
\end{array}$ & \begin{tabular}{|l} 
Câmara \\
Municipal de \\
São Paulo \\
\end{tabular} & Requerimento & Homenagem & 1 & $\begin{array}{l}\text { Voto de júbilo a } \\
\text { academia de judô } \\
\text { Yamazaki, feito } \\
\text { pelo vereador José } \\
\text { Maria Marin. } \\
\end{array}$ \\
\hline $\begin{array}{l}18 \text { de } \\
\text { março } \\
\text { de } 1969 \\
\end{array}$ & \begin{tabular}{|l} 
Câmara \\
Municipal de \\
São Paulo \\
\end{tabular} & Ordem do Dia & Discussão & & $\begin{array}{l}\text { Discussão na } \\
\text { Câmara Municipal - } \\
\text { Ordem do Dia- a } \\
\text { possibilidade de } \\
\text { concessão, } \\
\text { mediante } \\
\text { concorrência } \\
\text { pública o direito de } \\
\text { uso e exploração } \\
\text { do Autódromo de } \\
\text { Interlagos. } \\
\end{array}$ \\
\hline $\begin{array}{l}21 \text { de } \\
\text { março } \\
\text { de } 1969 \\
\end{array}$ & $\begin{array}{l}\text { Governo do } \\
\text { Estado de } \\
\text { São Paulo } \\
\end{array}$ & Ato Executivo & Encontro & $\begin{array}{l}\text { Secretaria de } \\
\text { Promoção } \\
\text { Social. }\end{array}$ & $\begin{array}{l}\text { Encontro dos } \\
\text { Clubes de Futebol } \\
\text { de Várzea da } \\
\text { capital com a } \\
\text { Secretaria de } \\
\text { Promoção Social, } \\
\text { visando a } \\
\text { integração dos } \\
\text { clubes na } \\
\text { recreação da } \\
\text { comunidade. }\end{array}$ \\
\hline
\end{tabular}




\begin{tabular}{|c|c|c|c|c|c|}
\hline $\begin{array}{l}01 \text { de } \\
\text { abril de } \\
1969\end{array}$ & $\begin{array}{l}\text { Governo do } \\
\text { Estado de } \\
\text { São Paulo }\end{array}$ & Ato Executivo & Decreto & $51607 / 69$ & \begin{tabular}{|l} 
Governador Abreu \\
Sodré determina a \\
obrigatoriedade \\
dos \\
estabelecimentos \\
de ensino do \\
estado a \\
participarem do \\
Campeonato \\
Colegial de \\
Esportes.
\end{tabular} \\
\hline $\begin{array}{l}03 \text { de } \\
\text { abril de } \\
1969\end{array}$ & $\begin{array}{l}\text { Governo do } \\
\text { Estado de } \\
\text { São Paulo }\end{array}$ & Ato Executivo & Portaria & $25 / 69$ & $\begin{array}{l}\text { Secretario do } \\
\text { DEFE, Antônio } \\
\text { Novelli, concede } \\
\text { anistia aos } \\
\text { estabelecimentos } \\
\text { de ensino que } \\
\text { infringiram } \\
\text { regulamento do } \\
\text { Campeonato } \\
\text { Colegial de } \\
\text { Esportes. }\end{array}$ \\
\hline $\begin{array}{l}11 \mathrm{de} \\
\text { abril de } \\
1969\end{array}$ & $\begin{array}{l}\text { Câmara } \\
\text { Municipal de } \\
\text { São Paulo }\end{array}$ & Requerimento & Ao executivo & 409 & $\begin{array}{l}\text { Vereador Alfredo } \\
\text { Martins pede } \\
\text { cessão em } \\
\text { comodato de } \\
\text { terreno público } \\
\text { para a Associação } \\
\text { Atlética } \\
\text { Portuguesa. }\end{array}$ \\
\hline $\begin{array}{l}11 \text { de } \\
\text { abril de } \\
1969\end{array}$ & $\begin{array}{l}\text { Câmara } \\
\text { Municipal de } \\
\text { São Paulo } \\
\end{array}$ & Requerimento & Ao executivo & 410 & $\begin{array}{l}\text { Vereador } \\
\text { Theodosina Ribeiro } \\
\text { pede que se } \\
\text { informe ao prefeito } \\
\text { de São Paulo que } \\
\text { devido as recentes } \\
\text { desapropriações o } \\
\text { Clube Atlético Elite } \\
\text { de Santana perdeu } \\
\text { sua praça de } \\
\text { esportes, e pede } \\
\text { que seja dado ao } \\
\text { clube parte de } \\
\text { outro terreno na } \\
\text { zona norte. }\end{array}$ \\
\hline $\begin{array}{l}15 \text { de } \\
\text { abril de } \\
1969\end{array}$ & $\begin{array}{l}\text { Governo do } \\
\text { Estado de } \\
\text { São Paulo }\end{array}$ & Ato Executivo & $\begin{array}{l}\text { Departamento de } \\
\text { Obras Públicas }\end{array}$ & Contrato & $\begin{array}{l}\text { Contratação da } \\
\text { Construtora Coan } \\
\text { LTDA para pintura } \\
\text { dos gigantes e } \\
\text { platibandas do } \\
\text { Ginásio do } \\
\text { lbirapuera. Obra a } \\
\text { ser executada em } \\
30 \text { dias e prevendo } \\
\text { reajustamento de } \\
\text { preço. } \\
\end{array}$ \\
\hline $\begin{array}{l}18 \text { de } \\
\text { abril de } \\
1969\end{array}$ & $\begin{array}{l}\text { Governo do } \\
\text { Estado de } \\
\text { São Paulo }\end{array}$ & Ato Executivo & Publicidade & DEFE & $\begin{array}{l}\text { Breve prestação de } \\
\text { Contas sobre as } \\
\text { ações do DEFE. }\end{array}$ \\
\hline
\end{tabular}




\begin{tabular}{|c|c|c|c|c|c|}
\hline $\begin{array}{l}26 \text { de } \\
\text { abril de } \\
1969\end{array}$ & $\begin{array}{l}\text { Câmara } \\
\text { Municipal de } \\
\text { São Paulo }\end{array}$ & Requerimento & Ao executivo & 568 & $\begin{array}{l}\text { Vereador Paulo } \\
\text { Soares Cintra } \\
\text { requer do prefeito } \\
\text { da cidade de São } \\
\text { Paulo que se } \\
\text { empenhe no } \\
\text { orçamento do ano } \\
\text { seguinte dotação } \\
\text { para a execução } \\
\text { das Olimpíadas } \\
\text { Infanto juvenis da } \\
\text { cidade. }\end{array}$ \\
\hline $\begin{array}{l}09 \text { de } \\
\text { maio de } \\
1969\end{array}$ & $\begin{array}{l}\text { Câmara } \\
\text { Municipal de } \\
\text { São Paulo }\end{array}$ & $\begin{array}{l}\text { Pronunciamen } \\
\text { to }\end{array}$ & Ao executivo & & $\begin{array}{l}\text { Discurso de Marin, } \\
\text { com pedido de } \\
\text { envio ao prefeito } \\
\text { de São Paulo, } \\
\text { Paulo Maluf, sobre } \\
\text { a reforma do } \\
\text { Autódromo de } \\
\text { Interlagos. Elogio } \\
\text { ao prefeito pelo } \\
\text { "carinho" com o } \\
\text { Pacaembu. } \\
\end{array}$ \\
\hline $\begin{array}{l}16 \text { de } \\
\text { maio de } \\
1969\end{array}$ & $\begin{array}{l}\text { Governo do } \\
\text { Estado de } \\
\text { São Paulo }\end{array}$ & Ato Executivo & autorização & $\begin{array}{l}\text { Secretaria de } \\
\text { Obras Públicas }\end{array}$ & $\begin{array}{l}\text { Sociedade } \\
\text { Brasileiro de } \\
\text { Engenharia e } \\
\text { Construções } \\
\text { Industriais } \\
\text { autorizada a } \\
\text { realizar obra no } \\
\text { prédio do DEFE. }\end{array}$ \\
\hline $\begin{array}{l}17 \text { de } \\
\text { maio de } \\
1969\end{array}$ & $\begin{array}{l}\text { Câmara } \\
\text { Municipal de } \\
\text { São Paulo }\end{array}$ & $\begin{array}{l}\text { Pronunciamen } \\
\text { to }\end{array}$ & Ao executivo & & $\begin{array}{l}\text { Novo discurso de } \\
\text { Marin sobre o } \\
\text { Autódromo de } \\
\text { Interlagos. Agora } \\
\text { pede reunião com } \\
\text { secretários } \\
\text { municipais de } \\
\text { Obras e Esportes. }\end{array}$ \\
\hline $\begin{array}{l}27 \text { de } \\
\text { maio de } \\
1969\end{array}$ & $\begin{array}{l}\text { Câmara } \\
\text { Municipal de } \\
\text { São Paulo }\end{array}$ & $\begin{array}{l}\text { PL do } \\
\text { Executivo }\end{array}$ & Ao Legislativo & $53 / 69$ & $\begin{array}{l}\text { Dispõe sobre a } \\
\text { criação da } \\
\text { Secretaria } \\
\text { municipal de } \\
\text { Esportes. }\end{array}$ \\
\hline \begin{tabular}{|l}
05 de \\
junho de \\
1969 \\
\end{tabular} & $\begin{array}{l}\text { Câmara } \\
\text { Municipal de } \\
\text { São Paulo }\end{array}$ & Projeto de Lei & Parecer & 5769 do PL 5369 & $\begin{array}{l}\text { O parecer da } \\
\text { Comissão de } \\
\text { Justiça sobre o } \\
\text { projeto de lei que } \\
\text { cria a Secretaria } \\
\text { Municipal de } \\
\text { Esportes. }\end{array}$ \\
\hline \begin{tabular}{|l}
05 de \\
junho de \\
1969 \\
\end{tabular} & $\begin{array}{l}\text { Governo do } \\
\text { Estado de } \\
\text { São Paulo }\end{array}$ & Ato Executivo & $\begin{array}{l}\text { Liberação de } \\
\text { recursos }\end{array}$ & DEFE & \begin{tabular}{|l|} 
Secretário de \\
Cultura, Esporte e \\
Turismo designa \\
recursos para o \\
Fundo das \\
Estâncias. \\
\end{tabular} \\
\hline
\end{tabular}




\begin{tabular}{|c|c|c|c|c|c|}
\hline $\begin{array}{l}10 \text { de } \\
\text { junho de } \\
1969\end{array}$ & $\begin{array}{l}\text { Governo do } \\
\text { Estado de } \\
\text { São Paulo }\end{array}$ & & Publicidade & TV Cultura & \begin{tabular}{|l} 
Publicidade sobre \\
programas de \\
esporte que seriam \\
transmitidos aos \\
sábados e \\
domingos, às \\
$19 \mathrm{~h} 30$, sobre \\
Futebol, sendo \\
Futebol Polêmico e \\
História do \\
Esporte, \\
respectivamente.
\end{tabular} \\
\hline $\begin{array}{l}12 \text { de } \\
\text { junho de } \\
1969\end{array}$ & $\begin{array}{l}\text { Governo do } \\
\text { Estado de } \\
\text { São Paulo } \\
\end{array}$ & Ato Executivo & Decreto & 52018 & \begin{tabular}{|l|} 
Regulamenta a \\
Inspeção de \\
Educação Física e \\
Esporte no \\
município de \\
Ourinhos. \\
\end{tabular} \\
\hline $\begin{array}{l}13 \text { de } \\
\text { junho de } \\
1969\end{array}$ & \begin{tabular}{|l} 
Câmara \\
Municipal de \\
São Paulo \\
\end{tabular} & Projeto de Lei & Parecer & 1169 & $\begin{array}{l}\text { Parecer sobre o } \\
\text { projeto de lei } 5869 \\
\text { que cria a } \\
\text { Secretaria } \\
\text { Municipal de } \\
\text { esportes, sendo o } \\
\text { parecer favorável } \\
\text { ao PL. } \\
\end{array}$ \\
\hline $\begin{array}{l}27 \text { de } \\
\text { junho de } \\
1969\end{array}$ & $\begin{array}{l}\text { Câmara } \\
\text { Municipal de } \\
\text { São Paulo }\end{array}$ & Requerimento & Ao executivo & 321 & $\begin{array}{l}\text { Pedido do } \\
\text { Vereador David } \\
\text { Roissen ao prefeito } \\
\text { de São Paulo que } \\
\text { crie centro } \\
\text { esportivo no } \\
\text { Parque Edu } \\
\text { Chaves. } \\
\end{array}$ \\
\hline $\begin{array}{l}28 \text { de } \\
\text { junho de } \\
1969\end{array}$ & $\begin{array}{l}\text { Governo do } \\
\text { Estado de } \\
\text { São Paulo } \\
\end{array}$ & Ato Executivo & Publicidade & & \begin{tabular}{|l|} 
Anúncio sobre a \\
posse do Novo \\
Conselho Regional \\
de Desportos do \\
Estado de São \\
Paulo. \\
\end{tabular} \\
\hline $\begin{array}{l}15 \text { de } \\
\text { agosto } \\
\text { de } 1969\end{array}$ & \begin{tabular}{|l} 
Câmara \\
Municipal de \\
São Paulo \\
\end{tabular} & Projeto de Lei & Parecer & 4/PL75 & $\begin{array}{l}\text { Parecer favorável } \\
\text { sobre o PL 75/69 } \\
\text { que visava a } \\
\text { criação dos Jogos } \\
\text { Mirins da Cidade } \\
\text { de São Paulo, de } \\
\text { autoria do vereador } \\
\text { Paolo Soares } \\
\text { Cintra. } \\
\end{array}$ \\
\hline $\begin{array}{l}26 \text { de } \\
\text { agosto } \\
\text { de } 1969\end{array}$ & $\begin{array}{l}\text { Câmara } \\
\text { Municipal de } \\
\text { São Paulo } \\
\end{array}$ & $\begin{array}{l}\text { Pronunciamen } \\
\text { to }\end{array}$ & Homenagem & & $\begin{array}{l}\text { Vereador José } \\
\text { Maria Marin faz } \\
\text { pronunciamento } \\
\text { enaltecendo a TV } \\
\text { Tupi pela } \\
\text { realização de } \\
\text { campeonato de } \\
\text { futebol mirim, } \\
\text { intitulado Dente de } \\
\text { Leite (ver se o } \\
\end{array}$ \\
\hline
\end{tabular}




\begin{tabular}{|c|c|c|c|c|c|}
\hline & & & & & \begin{tabular}{|l} 
termo começou \\
aqui).
\end{tabular} \\
\hline $\begin{array}{l}27 \text { de } \\
\text { agosto } \\
\text { de } 1969\end{array}$ & $\begin{array}{l}\text { Câmara } \\
\text { Municipal de } \\
\text { São Paulo }\end{array}$ & $\begin{array}{l}\text { Pronunciamen } \\
\text { to }\end{array}$ & Homenagem & & $\begin{array}{l}\text { Vereador Mario } \\
\text { Osassa elogia a } \\
\text { prefeitura de Paulo } \\
\text { Maluf por ter como } \\
\text { umas das } \\
\text { principais metas a } \\
\text { construção de } \\
\text { praças de esportes } \\
\text { e ginásios distritais } \\
\text { para que com o } \\
\text { esporte se eleve } \\
\text { moralmente a } \\
\text { mocidade. }\end{array}$ \\
\hline $\begin{array}{l}03 \text { de } \\
\text { setembr } \\
\text { o de } \\
1969\end{array}$ & $\begin{array}{l}\text { Governo do } \\
\text { Estado de } \\
\text { São Paulo }\end{array}$ & Parecer & Reunião & $\begin{array}{l}\text { Comissão de } \\
\text { Educação do } \\
\text { Estado }\end{array}$ & $\begin{array}{l}\text { Conselho Estadual } \\
\text { de Educação trata } \\
\text { da obrigatoriedade } \\
\text { da Educação } \\
\text { Física no Ensino e } \\
\text { na ampliação } \\
\text { dessa } \\
\text { determinação, não } \\
\text { ficando mais } \\
\text { apenas aos alunos } \\
\text { até } 18 \text { anos, ou até } \\
\text { o fim do colegial, } \\
\text { tirando o limite de } \\
\text { idade e integrando } \\
\text { o ensino superior, } \\
\text { mesmo que este } \\
\text { seja focado apenas } \\
\text { para competições. }\end{array}$ \\
\hline $\begin{array}{l}12 \text { de } \\
\text { setembr } \\
\text { o de } \\
1969\end{array}$ & $\begin{array}{l}\text { Câmara } \\
\text { Municipal de } \\
\text { São Paulo }\end{array}$ & $\begin{array}{l}\text { Pronunciamen } \\
\text { to }\end{array}$ & Discussão & & $\begin{array}{l}\text { Debate sobre as } \\
\text { condições do } \\
\text { Pacaembu na } \\
\text { Câmara Municipal. }\end{array}$ \\
\hline $\begin{array}{l}17 \text { de } \\
\text { setembr } \\
\text { o de } \\
1969\end{array}$ & $\begin{array}{l}\text { Câmara } \\
\text { Municipal de } \\
\text { São Paulo }\end{array}$ & $\begin{array}{l}\text { Pronunciamen } \\
\text { to }\end{array}$ & Homenagem & 662 & $\begin{array}{l}\text { Dar nome de uma } \\
\text { das ruas da cidade } \\
\text { de Friedenreich, } \\
\text { falecido } \\
\text { recentemente. }\end{array}$ \\
\hline $\begin{array}{l}24 \text { de } \\
\text { setembr } \\
\text { o de } \\
1969\end{array}$ & $\begin{array}{l}\text { Câmara } \\
\text { Municipal de } \\
\text { São Paulo }\end{array}$ & $\begin{array}{l}\text { Pronunciamen } \\
\text { to }\end{array}$ & & $\begin{array}{l}\text { Pequeno } \\
\text { Expediente }\end{array}$ & $\begin{array}{l}\text { Vereador José } \\
\text { Maria Marin fala da } \\
\text { reabertura do } \\
\text { Pacaembu após } \\
\text { fechamento de } 1 \\
\text { ano para reformas. }\end{array}$ \\
\hline $\begin{array}{l}03 \text { de } \\
\text { outubro } \\
\text { de } 1969\end{array}$ & $\begin{array}{l}\text { Câmara } \\
\text { Municipal de } \\
\text { São Paulo }\end{array}$ & $\begin{array}{l}\text { Pronunciamen } \\
\text { to }\end{array}$ & Discussão & & $\begin{array}{l}\text { Vereador Paulo } \\
\text { Soares Cintra fala } \\
\text { da questão dos } \\
\text { espaços para } \\
\text { prática de esportes } \\
\text { na cidade de São } \\
\text { Paulo e chama } \\
\text { membros da } \\
\text { sociedade civil, } \\
\text { dirigentes }\end{array}$ \\
\hline
\end{tabular}




\begin{tabular}{|c|c|c|c|c|c|}
\hline & & & & & $\begin{array}{l}\text { esportivos e } \\
\text { membros do poder } \\
\text { executivo para } \\
\text { debate no plenário. }\end{array}$ \\
\hline $\begin{array}{l}15 \text { de } \\
\text { outubro } \\
\text { de } 1969 \\
\end{array}$ & \begin{tabular}{|l|} 
Governo do \\
Estado de \\
São Paulo \\
\end{tabular} & Ato Executivo & Publicidade & & $\begin{array}{l}\text { Aprovado (?) plano } \\
\text { estadual de } \\
\text { Esportes. } \\
\end{array}$ \\
\hline $\begin{array}{l}18 \text { de } \\
\text { outubro } \\
\text { de } 1969\end{array}$ & \begin{tabular}{|l} 
Governo do \\
Estado de \\
São Paulo
\end{tabular} & Ato Executivo & Decreto & $17 / 69$ & \begin{tabular}{|l|} 
Dispõe sobre o \\
museu do Esporte \\
Nacional.
\end{tabular} \\
\hline \begin{tabular}{|l|}
21 de \\
outubro \\
de 1969 \\
\end{tabular} & \begin{tabular}{|l|} 
Governo do \\
Estado de \\
São Paulo \\
\end{tabular} & Ato Executivo & Publicidade & & $\begin{array}{l}\text { Criado Museu no } \\
\text { Esporte Nacional }\end{array}$ \\
\hline \begin{tabular}{|l|}
24 de \\
outubro \\
de 1969 \\
\end{tabular} & \begin{tabular}{|l|} 
Governo do \\
Estado de \\
São Paulo \\
\end{tabular} & Ato Executivo & Publicidade & & $\begin{array}{l}\text { Remodelado } \\
\text { Parque Esportivo } \\
\text { do DEFE. }\end{array}$ \\
\hline $\begin{array}{l}05 \text { de } \\
\text { novembr } \\
\text { o de } \\
1969 \\
\end{array}$ & $\begin{array}{l}\text { Câmara } \\
\text { municipal de } \\
\text { São Paulo }\end{array}$ & $\begin{array}{l}\text { Pronunciamen } \\
\text { to }\end{array}$ & Discussão & & $\begin{array}{l}\text { Discussão sobre o } \\
\text { Pacaembu entre os } \\
\text { vereadores, em } \\
\text { especial sobre o } \\
\text { fechamento da } \\
\text { Concha. } \\
\end{array}$ \\
\hline $\begin{array}{l}08 \text { de } \\
\text { novembr } \\
\text { o de } \\
1969\end{array}$ & $\begin{array}{l}\text { Governo do } \\
\text { Estado de } \\
\text { São Paulo }\end{array}$ & Ato Executivo & Decreto & $\begin{array}{l}\text { Decreto de } 7 \text { de } \\
\text { novembro }\end{array}$ & $\begin{array}{l}\text { Oficializa o } \\
\text { campeonato de } \\
\text { futebol realizado } \\
\text { pela TV Tupi, o } \\
\text { "Futebol Dente de } \\
\text { Leite" como evento } \\
\text { oficial do Estado. } \\
\end{array}$ \\
\hline $\begin{array}{l}15 \text { de } \\
\text { novembr } \\
\text { o de } \\
1969\end{array}$ & $\begin{array}{l}\text { Governo do } \\
\text { Estado de } \\
\text { São Paulo }\end{array}$ & Ato Executivo & autorização & Contrato & $\begin{array}{l}\text { Abertas diversas } \\
\text { concorrências } \\
\text { pequenas para } \\
\text { aquisição de } \\
\text { material através do } \\
\text { FADA (Fundo } \\
\text { Amparo ao } \\
\text { Desporto Amador). }\end{array}$ \\
\hline \begin{tabular}{|l|}
16 de \\
novembr \\
o de \\
1969 \\
\end{tabular} & $\begin{array}{l}\text { Governo do } \\
\text { Estado de } \\
\text { São Paulo } \\
\end{array}$ & Ato Executivo & Publicidade & $\begin{array}{l}\text { Liberação de } \\
\text { Recursos } \\
\end{array}$ & $\begin{array}{l}\text { Indicação de } \\
\text { dotações para o } \\
\text { DEFE }\end{array}$ \\
\hline $\begin{array}{l}18 \text { de } \\
\text { novembr } \\
\text { o de } \\
1969\end{array}$ & $\begin{array}{l}\text { Câmara } \\
\text { Municipal de } \\
\text { São Paulo }\end{array}$ & Indicação & Ao executivo & 718 & $\begin{array}{l}\text { Vereador José } \\
\text { Maria Marin indica } \\
\text { ao prefeito que } \\
\text { proceda com } \\
\text { estudos para a } \\
\text { criação de praça } \\
\text { de esportes no } \\
\text { Jardim Catanduva. }\end{array}$ \\
\hline $\begin{array}{l}22 \text { de } \\
\text { novembr } \\
\text { o de } \\
1969\end{array}$ & $\begin{array}{l}\text { Governo do } \\
\text { Estado de } \\
\text { São Paulo }\end{array}$ & Ato Executivo & Ordem de serviço & DEFE 02 & $\begin{array}{l}\text { Secretário Novelli } \\
\text { autoria obras na } \\
\text { piscina do DEFE. } \\
\text { Construtora Sarima } \\
\text { Engrenharia LTDA. }\end{array}$ \\
\hline $\begin{array}{l}25 \text { de } \\
\text { novembr } \\
\text { o de } \\
1969\end{array}$ & $\begin{array}{l}\text { Governo do } \\
\text { Estado de } \\
\text { São Paulo }\end{array}$ & Ato Executivo & Contrato & 7331 & $\begin{array}{l}\text { Publicado Extrato } \\
\text { de contrato do } \\
\text { DEFE com a } \\
\text { Revista Esporte e } \\
\text { Educação da }\end{array}$ \\
\hline
\end{tabular}




\begin{tabular}{|c|c|c|c|c|c|}
\hline & & & & & $\begin{array}{l}\text { Associação do } \\
\text { Professores de } \\
\text { Educação Física } \\
\text { de São Paulo para } \\
\text { realização de } \\
\text { publicações } \\
\text { temáticas. }\end{array}$ \\
\hline $\begin{array}{l}09 \text { de } \\
\text { dezembr } \\
\text { o de } \\
1969\end{array}$ & $\begin{array}{l}\text { Governo do } \\
\text { Estado de } \\
\text { São Paulo }\end{array}$ & & Publicidade & & $\begin{array}{l}\text { Cronista Esportivos } \\
\text { Entregam Pena de } \\
\text { Ouro ao } \\
\text { Governador. } \\
\text { Prêmio concedido } \\
\text { aos que prestam } \\
\text { serviços ao } \\
\text { esporte, e pela } \\
\text { primeira vez cedido } \\
\text { a que não faz parte } \\
\text { do quadro da } \\
\text { ACESP - } \\
\text { Associação dos } \\
\text { Cronistas } \\
\text { Esportivos. }\end{array}$ \\
\hline \begin{tabular}{|l|}
10 de \\
dezembr \\
o de \\
1969 \\
\end{tabular} & $\begin{array}{l}\text { Governo do } \\
\text { Estado de } \\
\text { São Paulo }\end{array}$ & Ato Executivo & Reunião & Conselho & $\begin{array}{l}\text { Ata de reunião do } \\
\text { Conselho Estadual } \\
\text { de Desportos. }\end{array}$ \\
\hline $\begin{array}{l}23 \text { de } \\
\text { dezembr } \\
\text { o de } \\
1969 \\
\end{array}$ & $\begin{array}{l}\text { Governo do } \\
\text { Estado de } \\
\text { São Paulo }\end{array}$ & Ato Executivo & Publicidade & & $\begin{array}{l}\text { Construção de } \\
\text { Praça de Esportes } \\
\text { em Monte } \\
\text { Aprazível - } \\
\text { Paraíso. }\end{array}$ \\
\hline $\begin{array}{l}25 \text { de } \\
\text { fevereiro } \\
\text { de } 1970\end{array}$ & $\begin{array}{l}\text { Governo do } \\
\text { Estado de } \\
\text { São Paulo }\end{array}$ & Ato Executivo & Decreto & s/n 25 & $\begin{array}{l}\text { Governador Abreu } \\
\text { Sodré autoriza } \\
\text { convênio com a } \\
\text { Prefeitura de } \\
\text { Mendonça para } \\
\text { que esta construa } \\
\text { praça de esportes } \\
\text { em terreno do } \\
\text { estado. }\end{array}$ \\
\hline $\begin{array}{l}25 \text { de } \\
\text { fevereiro } \\
\text { de } 1970 \\
\end{array}$ & $\begin{array}{l}\text { Governo do } \\
\text { Estado de } \\
\text { São Paulo }\end{array}$ & Ato Executivo & Decreto & $\mathrm{s} / \mathrm{n} 25$ & $\begin{array}{l}\text { Dispõe sobre o } \\
\text { funcionamento da } \\
\text { Inspetoria de } \\
\text { Educação Física e } \\
\text { Esportes no } \\
\text { Município de } \\
\text { Ituverava. } \\
\end{array}$ \\
\hline $\begin{array}{l}27 \text { de } \\
\text { fevereiro } \\
\text { de } 1970\end{array}$ & $\begin{array}{l}\text { Governo do } \\
\text { Estado de } \\
\text { São Paulo }\end{array}$ & Ato Executivo & Decreto & $s / n 2$ & $\begin{array}{l}\text { Fixa a frota de } \\
\text { veículos da } \\
\text { Secretaria de } \\
\text { Cultura, Esportes e } \\
\text { Turismo do estado } \\
\text { e da outras } \\
\text { providências. }\end{array}$ \\
\hline $\begin{array}{l}04 \text { de } \\
\text { março } \\
\text { de } 1970\end{array}$ & $\begin{array}{l}\text { Governo do } \\
\text { Estado de } \\
\text { São Paulo }\end{array}$ & Ato Executivo & Publicidade & Inauguração & $\begin{array}{l}\text { Governador } \\
\text { inaugura novas } \\
\text { instalações do } \\
\text { DEFE. }\end{array}$ \\
\hline
\end{tabular}




\begin{tabular}{|c|c|c|c|c|c|}
\hline $\begin{array}{l}06 \text { de } \\
\text { março } \\
\text { de } 1970\end{array}$ & $\begin{array}{l}\text { Câmara } \\
\text { Municipal de } \\
\text { São Paulo }\end{array}$ & Indicação & Ao executivo & 4170 & $\begin{array}{l}\text { indicação para } \\
\text { construção de } \\
\text { arquibancadas de } \\
\text { concreto no lugar } \\
\text { das de madeira } \\
\text { existentes no } \\
\text { campo de baseball } \\
\text { da prefeitura no } \\
\text { Bom Retiro. }\end{array}$ \\
\hline $\begin{array}{l}06 \text { de } \\
\text { março } \\
\text { de } 1970 \\
\end{array}$ & $\begin{array}{l}\text { Tribunal de } \\
\text { Contas }\end{array}$ & Acordão & Consulta & 3646 & \begin{tabular}{|l} 
Trata da \\
possibilidade de \\
repasse a \\
entidades sem fins \\
lucrativos ligadas \\
ao esporte amador \\
\end{tabular} \\
\hline $\begin{array}{l}14 \text { de } \\
\text { março } \\
\text { de } 1970\end{array}$ & $\begin{array}{l}\text { Governo do } \\
\text { Estado de } \\
\text { São Paulo } \\
\end{array}$ & Ato Executivo & autorização & convênio & $\begin{array}{l}\text { Governador Abreu } \\
\text { Sodré autoriza } \\
\text { convênio com a } \\
\text { Prefeitura de Nova } \\
\text { Europa para que } \\
\text { esta construa } \\
\text { praça de esportes } \\
\text { em terreno do } \\
\text { estado. }\end{array}$ \\
\hline $\begin{array}{l}14 \text { de } \\
\text { março } \\
\text { de } 1970\end{array}$ & $\begin{array}{l}\text { Governo do } \\
\text { Estado de } \\
\text { São Paulo }\end{array}$ & Ato Executivo & autorização & convênio & $\begin{array}{l}\text { Governador Abreu } \\
\text { Sodré autoriza } \\
\text { convênio com a } \\
\text { Prefeitura de Sales } \\
\text { para que esta } \\
\text { construa quadra de } \\
\text { cestobol em } \\
\text { terreno do estado. }\end{array}$ \\
\hline $\begin{array}{l}17 \text { de } \\
\text { março } \\
\text { de } 1970 \\
\end{array}$ & $\begin{array}{l}\text { Câmara } \\
\text { Municipal de } \\
\text { São Paulo } \\
\end{array}$ & Indicação & Ao executivo & $127 / 70$ & $\begin{array}{l}\text { Indicação para que } \\
\text { se construa praça } \\
\text { de esportes no } \\
\text { Jardim Adhemar } \\
\text { "nos moldes das } \\
\text { que vêm sendo } \\
\text { construídas por } \\
\text { aquela secretaria" } \\
\end{array}$ \\
\hline $\begin{array}{l}25 \text { de } \\
\text { março } \\
\text { de } 1970\end{array}$ & $\begin{array}{l}\text { Governo do } \\
\text { Estado de } \\
\text { São Paulo }\end{array}$ & Ato Executivo & autorização & licitação DEFE & \begin{tabular}{|l|} 
Abertura de \\
concorrência \\
pública para \\
aquisição de \\
material esportivo.
\end{tabular} \\
\hline $\begin{array}{l}25 \text { de } \\
\text { março } \\
\text { de } 1970\end{array}$ & $\begin{array}{l}\text { Câmara } \\
\text { Municipal de } \\
\text { São Paulo }\end{array}$ & $\begin{array}{l}\text { Pronunciamen } \\
\text { to }\end{array}$ & & & $\begin{array}{l}\text { Vereador Luiz } \\
\text { Gonzaga Pereira } \\
\text { fala da intercessão } \\
\text { do ministro Jarbas } \\
\text { Passarinho no } \\
\text { problema do } \\
\text { Futebol. }\end{array}$ \\
\hline $\begin{array}{l}31 \text { de } \\
\text { março } \\
\text { de } 1970\end{array}$ & $\begin{array}{l}\text { Governo do } \\
\text { Estado de } \\
\text { São Paulo }\end{array}$ & Ato Executivo & autorização & & $\begin{array}{l}\text { Abertura de } \\
\text { concorrência } \\
\text { pública para } \\
\text { aquisição de } \\
\text { material esportivo. } \\
\text { (republicacão) }\end{array}$ \\
\hline
\end{tabular}




\begin{tabular}{|c|c|c|c|c|c|}
\hline $\begin{array}{l}07 \text { de } \\
\text { abril de } \\
1970\end{array}$ & $\begin{array}{l}\text { Câmara } \\
\text { Municipal de } \\
\text { São Paulo }\end{array}$ & Indicação & Ao executivo & 91 & $\begin{array}{l}\text { Vereador José } \\
\text { Maria Marin indica } \\
\text { ao prefeito que de } \\
\text { o nome de Thomaz } \\
\text { Mazzoni, da } \\
\text { Gazeta Esportiva, } \\
\text { a um dos } \\
\text { logradouros } \\
\text { públicos da cidade. }\end{array}$ \\
\hline $\begin{array}{l}10 \text { de } \\
\text { abril de } \\
1970\end{array}$ & $\begin{array}{l}\text { Câmara } \\
\text { Municipal de } \\
\text { São Paulo }\end{array}$ & $\begin{array}{l}\text { Pronunciamen } \\
\text { to }\end{array}$ & Homenagem & & $\begin{array}{l}\text { Vereador Armando } \\
\text { Simões Netto } \\
\text { enaltece a decisão } \\
\text { do prefeito de dar o } \\
\text { nome do } \\
\text { desportista Alfredo } \\
\text { Inácio Trindade ao } \\
\text { centro Educacional } \\
\text { Esportivo de } \\
\text { Santana. }\end{array}$ \\
\hline $\begin{array}{l}29 \text { de } \\
\text { abril de } \\
1970 \\
\end{array}$ & $\begin{array}{l}\text { Câmara } \\
\text { Municipal de } \\
\text { São Paulo } \\
\end{array}$ & $\begin{array}{l}\text { Pronunciamen } \\
\text { to }\end{array}$ & Ao executivo & & \begin{tabular}{|l} 
Vereadores José \\
Maria Marin e \\
Manoel Salas \\
cobram do prefeito \\
da cidade que \\
resolva impasse \\
sobre terreno entre \\
a prefeitura e o \\
esporte clube \\
Adamus. \\
\end{tabular} \\
\hline $\begin{array}{l}29 \text { de } \\
\text { abril de } \\
1970\end{array}$ & $\begin{array}{l}\text { Governo do } \\
\text { Estado de } \\
\text { São Paulo }\end{array}$ & Ato Executivo & autorização & licitação DEFE & $\begin{array}{l}\text { Abertura de } \\
\text { concorrência } \\
\text { pública para } \\
\text { aquisição de } \\
\text { material esportivo } \\
\text { e tomada de } \\
\text { preços para } \\
\text { aquisição de } \\
\text { aparelhos } \\
\text { telefônicos. }\end{array}$ \\
\hline $\begin{array}{l}05 \text { de } \\
\text { maio de } \\
1970 \\
\end{array}$ & $\begin{array}{l}\text { Governo do } \\
\text { Estado de } \\
\text { São Paulo } \\
\end{array}$ & Ato Executivo & Decreto & 4 & \begin{tabular}{|l} 
Dispõe sobre o \\
funcionamento da \\
Inspetoria de \\
Educação Física e \\
Esportes do \\
município de \\
Avaré.
\end{tabular} \\
\hline $\begin{array}{l}26 \text { de } \\
\text { maio de } \\
1970\end{array}$ & $\begin{array}{l}\text { Governo do } \\
\text { Estado de } \\
\text { São Paulo }\end{array}$ & Ato Executivo & autorização & convênio & $\begin{array}{l}\text { Governador Abreu } \\
\text { Sodré autoriza } \\
\text { convênio com a } \\
\text { Prefeitura de José } \\
\text { Bonifácio para que } \\
\text { esta construa } \\
\text { praça de esportes } \\
\text { em terreno do } \\
\text { estado. }\end{array}$ \\
\hline $\begin{array}{l}26 \text { de } \\
\text { maio de } \\
1970\end{array}$ & $\begin{array}{l}\text { Governo do } \\
\text { Estado de } \\
\text { São Paulo }\end{array}$ & Ato Executivo & autorização & convênio & $\begin{array}{l}\text { Governador Abreu } \\
\text { Sodré autoriza } \\
\text { convênio com a } \\
\text { Prefeitura de Santa } \\
\text { Adélia para que }\end{array}$ \\
\hline
\end{tabular}




\begin{tabular}{|c|c|c|c|c|c|}
\hline & & & & & $\begin{array}{l}\text { esta construa } \\
\text { praça de esportes } \\
\text { em terreno do } \\
\text { estado. }\end{array}$ \\
\hline \begin{tabular}{|l}
30 de \\
maio de \\
1970 \\
\end{tabular} & $\begin{array}{l}\text { Governo do } \\
\text { Estado de } \\
\text { São Paulo }\end{array}$ & Ato Executivo & Publicidade & convênio & \begin{tabular}{|l|} 
Publicidade sobre \\
os convênios \\
firmados com \\
prefeituras do \\
estado para a \\
promoção do \\
esporte. \\
Concessão de \\
recursos para \\
construção de \\
praça de esportes - \\
municípios \\
listados. \\
\end{tabular} \\
\hline \multicolumn{6}{|c|}{ Não houve publicações sobre esporte no DO no período de Copa do Mundo } \\
\hline $\begin{array}{l}02 \text { de } \\
\text { julho de } \\
1970\end{array}$ & $\begin{array}{l}\text { Tribunal de } \\
\text { Contas }\end{array}$ & $\begin{array}{l}\text { Pronunciamen } \\
\text { to }\end{array}$ & Homenagem & & $\begin{array}{l}\text { Voto de jubilo ao tri } \\
\text { campeonato do } \\
\text { Brasil na Copa do } \\
\text { Mundo. }\end{array}$ \\
\hline $\begin{array}{l}02 \text { de } \\
\text { julho de } \\
1970\end{array}$ & $\begin{array}{l}\text { Assembleia } \\
\text { Legislativa } \\
\text { de São } \\
\text { Paulo }\end{array}$ & $\begin{array}{l}\text { Pronunciamen } \\
\text { to }\end{array}$ & Discussão & & $\begin{array}{l}\text { Deputado Pedro } \\
\text { Geraldo Costa diz } \\
\text { a Deputado Nadir } \\
\text { Kenan que não é } \\
\text { hora de perder } \\
\text { esperanças devido } \\
\text { ao momento da } \\
\text { Nação, visto que } \\
\text { como no esporte - } \\
\text { tricampeonato - o } \\
\text { governo } \\
\text { "revolucionário" } \\
\text { está preocupado } \\
\text { com todas as } \\
\text { pautas. }\end{array}$ \\
\hline $\begin{array}{l}03 \text { de } \\
\text { julho de } \\
1970\end{array}$ & $\begin{array}{l}\text { Câmara } \\
\text { Municipal de } \\
\text { São Paulo }\end{array}$ & $\begin{array}{l}\text { Pronunciamen } \\
\text { to }\end{array}$ & Discussão & & $\begin{array}{l}\text { Debate dos } \\
\text { vereadores, com } \\
\text { destaque para o } \\
\text { vereador João } \\
\text { Carlos Meirelles, } \\
\text { sobre a vitória do } \\
\text { Brasil na Copa do } \\
\text { Mundo e sobre } \\
\text { esporte em geral. }\end{array}$ \\
\hline $\begin{array}{l}03 \text { de } \\
\text { julho de } \\
1970\end{array}$ & $\begin{array}{l}\text { Câmara } \\
\text { Municipal de } \\
\text { São Paulo }\end{array}$ & $\begin{array}{l}\text { Pronunciamen } \\
\text { to }\end{array}$ & Homenagem & & $\begin{array}{l}\text { Adhemar de Barros } \\
\text { faz discurso na } \\
\text { câmara sobre a } \\
\text { vitória do Brasil na } \\
\text { Copa. }\end{array}$ \\
\hline $\begin{array}{l}04 \text { de } \\
\text { julho de } \\
1970\end{array}$ & $\begin{array}{l}\text { Assembleia } \\
\text { Legislativa } \\
\text { de São } \\
\text { Paulo }\end{array}$ & $\begin{array}{l}\text { Pronunciamen } \\
\text { to }\end{array}$ & Discussão & & $\begin{array}{l}\text { Debate dos } \\
\text { deputados sobre a } \\
\text { vitória do Brasil na } \\
\text { Copa do Mundo e } \\
\text { sobre esporte em } \\
\text { geral. }\end{array}$ \\
\hline
\end{tabular}




\begin{tabular}{|c|c|c|c|c|c|}
\hline $\begin{array}{l}04 \text { de } \\
\text { julho de } \\
1970\end{array}$ & $\begin{array}{l}\text { Assembleia } \\
\text { Legislativa } \\
\text { de São } \\
\text { Paulo }\end{array}$ & $\begin{array}{l}\text { Pronunciamen } \\
\text { to }\end{array}$ & Discussão & & $\begin{array}{l}\text { Debate dos } \\
\text { deputados sobre a } \\
\text { vitória do Brasil na } \\
\text { Copa do Mundo e } \\
\text { sobre esporte em } \\
\text { geral. Discurso } \\
\text { sobre integração } \\
\text { nacional da } \\
\text { juventude. }\end{array}$ \\
\hline $\begin{array}{l}07 \text { de } \\
\text { julho de } \\
1970\end{array}$ & $\begin{array}{l}\text { Assembleia } \\
\text { Legislativa } \\
\text { de São } \\
\text { Paulo } \\
\end{array}$ & $\begin{array}{l}\text { Pronunciamen } \\
\text { to }\end{array}$ & Discussão & & $\begin{array}{l}\text { Debate dos } \\
\text { deputados sobre a } \\
\text { vitória do Brasil na } \\
\text { Copa do Mundo e } \\
\text { sobre esporte em } \\
\text { geral. Discurso } \\
\text { sobre patriotismo } \\
\text { de religião. } \\
\end{array}$ \\
\hline $\begin{array}{l}07 \text { de } \\
\text { julho de } \\
1970\end{array}$ & $\begin{array}{l}\text { Câmara } \\
\text { Municipal de } \\
\text { São Paulo }\end{array}$ & $\begin{array}{l}\text { Pronunciamen } \\
\text { to }\end{array}$ & Homenagem & & $\begin{array}{l}\text { Homenagem ao } \\
\text { Lions Clube - } \\
\text { Ainda sobre a } \\
\text { Copa. }\end{array}$ \\
\hline $\begin{array}{l}07 \text { de } \\
\text { julho de } \\
1970\end{array}$ & $\begin{array}{l}\text { Câmara } \\
\text { Municipal de } \\
\text { São Paulo }\end{array}$ & $\begin{array}{l}\text { Pronunciamen } \\
\text { to }\end{array}$ & Votação & & $\begin{array}{l}\text { Votação sobre os } \\
\text { fuscas que o } \\
\text { prefeito Paulo } \\
\text { Maluf prometeu } \\
\text { aos jogadores da } \\
\text { seleção brasileira. } \\
\text { Vereador Sampaio } \\
\text { Doria retira o voto } \\
\text { contrário ao } \\
\text { chamado "Projeto } \\
\text { Volkswagen". }\end{array}$ \\
\hline $\begin{array}{l}16 \text { de } \\
\text { julho de } \\
1970\end{array}$ & $\begin{array}{l}\text { Assembleia } \\
\text { Legislativa } \\
\text { de São } \\
\text { Paulo }\end{array}$ & Parecer & & 7 & $\begin{array}{l}\text { Parecer sobre } \\
\text { projeto do } \\
\text { deputado Ary Silva } \\
\text { para se instituir a } \\
\text { "Medalha Palácio } 9 \\
\text { de julho" a ser } \\
\text { concedida a } \\
\text { seleção brasileira } \\
\text { de futebol de } 70 \text { e } \\
\text { de 62. Parecer } \\
\text { favorável e projeto } \\
\text { adendado. }\end{array}$ \\
\hline $\begin{array}{l}17 \text { de } \\
\text { julho de } \\
1970\end{array}$ & $\begin{array}{l}\text { Assembleia } \\
\text { Legislativa } \\
\text { de São } \\
\text { Paulo }\end{array}$ & Projeto de Lei & Discussão & 60 & $\begin{array}{l}\text { Para dar o nome } \\
\text { de Alfredo Ignácio } \\
\text { Trindade, } \\
\text { desportista e ligado } \\
\text { a Federação } \\
\text { Paulista de } \\
\text { Futebol, a grupo } \\
\text { escolar na Vila } \\
\text { Nive. Deputado Ary } \\
\text { Silva. }\end{array}$ \\
\hline $\begin{array}{l}17 \text { de } \\
\text { julho de } \\
1970\end{array}$ & $\begin{array}{l}\text { Assembleia } \\
\text { Legislativa } \\
\text { de São } \\
\text { Paulo } \\
\end{array}$ & $\begin{array}{l}\text { Ato } \\
\text { Legislativo }\end{array}$ & Convocação & Comissão & $\begin{array}{l}\text { Convocação aos } \\
\text { deputados } \\
\text { membros da } \\
\text { Comissão de } \\
\text { Cultura, Esporte e } \\
\text { Turismo para } \\
\end{array}$ \\
\hline
\end{tabular}




\begin{tabular}{|c|c|c|c|c|c|}
\hline & & & & & $\begin{array}{l}\text { eleição de } \\
\text { presidente da } \\
\text { Comissão. }\end{array}$ \\
\hline $\begin{array}{l}18 \text { de } \\
\text { julho de } \\
1970\end{array}$ & $\begin{array}{l}\text { Assembleia } \\
\text { Legislativa } \\
\text { de São } \\
\text { Paulo }\end{array}$ & $\begin{array}{l}\text { Ato } \\
\text { Legislativo }\end{array}$ & Convocação & Comissão & $\begin{array}{l}\text { Convocação aos } \\
\text { deputados } \\
\text { membros da } \\
\text { Comissão de } \\
\text { Cultura, Esporte e } \\
\text { Turismo para } \\
\text { eleição de vice } \\
\text { presidente da } \\
\text { Comissão. }\end{array}$ \\
\hline $\begin{array}{l}18 \text { de } \\
\text { julho de } \\
1970\end{array}$ & $\begin{array}{l}\text { Assembleia } \\
\text { Legislativa } \\
\text { de São } \\
\text { Paulo } \\
\end{array}$ & $\begin{array}{l}\text { Ato } \\
\text { Legislativo }\end{array}$ & Convocação & Comissão & $\begin{array}{l}\text { Ata da reunião da } \\
\text { Comissão de } \\
\text { Cultura, Esporte e } \\
\text { Turismo. } \\
\end{array}$ \\
\hline $\begin{array}{l}21 \text { de } \\
\text { julho de } \\
1970\end{array}$ & $\begin{array}{l}\text { Assembleia } \\
\text { Legislativa } \\
\text { de São } \\
\text { Paulo }\end{array}$ & $\begin{array}{l}\text { Pronunciamen } \\
\text { to }\end{array}$ & & & $\begin{array}{l}\text { Wadih Helu faz } \\
\text { discurso sobre o } \\
\text { grande momento } \\
\text { da mocidade } \\
\text { brasileira e do } \\
\text { apoio público ao } \\
\text { esporte. }\end{array}$ \\
\hline $\begin{array}{l}21 \mathrm{de} \\
\text { julho de } \\
1970\end{array}$ & $\begin{array}{l}\text { Assembleia } \\
\text { Legislativa } \\
\text { de São } \\
\text { Paulo }\end{array}$ & $\begin{array}{l}\text { Pronunciamen } \\
\text { to }\end{array}$ & Discussão & & $\begin{array}{l}\text { Pronunciamento } \\
\text { sobre a } \\
\text { importância dos } \\
\text { esportes para } \\
\text { afirmação nacional, } \\
\text { sobretudo o } \\
\text { futebol. }\end{array}$ \\
\hline
\end{tabular}

Dança das cadeiras no Defe neste mês - DAS e DAIS concedidos, relotação, aposentadorias e disponibilidade.

\begin{tabular}{|c|c|c|c|c|c|}
\hline $\begin{array}{l}23 \text { de } \\
\text { julho de } \\
1970\end{array}$ & $\begin{array}{l}\text { Assembleia } \\
\text { Legislativa } \\
\text { de São } \\
\text { Paulo } \\
\end{array}$ & Indicação & Ao executivo & 279 & $\begin{array}{l}\text { Deputado Cunha } \\
\text { Braga indica ao } \\
\text { executivo que } \\
\text { construa quadra de } \\
\text { tênis no complexo } \\
\text { do lbirapuera. } \\
\end{array}$ \\
\hline $\begin{array}{l}23 \text { de } \\
\text { julho de } \\
1970\end{array}$ & $\begin{array}{l}\text { Assembleia } \\
\text { Legislativa } \\
\text { de São } \\
\text { Paulo }\end{array}$ & Indicação & Ao executivo & 101 & $\begin{array}{l}\text { Voto de } \\
\text { congratulação aos } \\
\text { atletas } \\
\text { participantes da } \\
\text { "Taça Davis", e as } \\
\text { Federações } \\
\text { brasileira e paulista } \\
\text { de tênis. }\end{array}$ \\
\hline $\begin{array}{l}25 \text { de } \\
\text { julho de } \\
1970\end{array}$ & $\begin{array}{l}\text { Assembleia } \\
\text { Legislativa } \\
\text { de São } \\
\text { Paulo }\end{array}$ & $\begin{array}{l}\text { Pronunciamen } \\
\text { to }\end{array}$ & Discussão & & $\begin{array}{l}\text { Discussão sobre o } \\
\text { mérito do chamado } \\
\text { "Projeto } \\
\text { Volkswagen". }\end{array}$ \\
\hline $\begin{array}{l}25 \text { de } \\
\text { julho de } \\
1970\end{array}$ & $\begin{array}{l}\text { Assembleia } \\
\text { Legislativa } \\
\text { de São } \\
\text { Paulo }\end{array}$ & $\begin{array}{l}\text { Ato } \\
\text { Legislativo }\end{array}$ & Convocação & Comissão & $\begin{array}{l}\text { Ata da reunião dos } \\
\text { membros da } \\
\text { Comissão de } \\
\text { Cultura, Esporte e } \\
\text { Turismo para } \\
\text { eleição de vice } \\
\text { presidente da } \\
\text { Comissão. Eleito }\end{array}$ \\
\hline
\end{tabular}




\begin{tabular}{|c|c|c|c|c|c|}
\hline & & & & & $\begin{array}{l}\text { deputado Nabil Abi } \\
\text { Chedid. }\end{array}$ \\
\hline $\begin{array}{l}30 \text { de } \\
\text { julho de } \\
1970\end{array}$ & $\begin{array}{l}\text { Governo do } \\
\text { Estado de } \\
\text { São Paulo }\end{array}$ & Ato Executivo & Decreto & do dia & $\begin{array}{l}\text { Dispõe sobre o } \\
\text { funcionamento da } \\
\text { Inspetoria de } \\
\text { Educação Física e } \\
\text { Esportes do } \\
\text { município de } \\
\text { Adamantina. }\end{array}$ \\
\hline $\begin{array}{l}30 \text { de } \\
\text { julho de } \\
1970\end{array}$ & $\begin{array}{l}\text { Governo do } \\
\text { Estado de } \\
\text { São Paulo }\end{array}$ & Ato Executivo & Decreto & do dia & $\begin{array}{l}\text { Dispõe sobre o } \\
\text { funcionamento da } \\
\text { Inspetoria de } \\
\text { Educação Física e } \\
\text { Esportes do } \\
\text { município de } \\
\text { Batatais. }\end{array}$ \\
\hline $\begin{array}{l}30 \text { de } \\
\text { julho de } \\
1970\end{array}$ & $\begin{array}{l}\text { Governo do } \\
\text { Estado de } \\
\text { São Paulo }\end{array}$ & Ato Executivo & Decreto & do dia & $\begin{array}{l}\text { Dispõe sobre o } \\
\text { funcionamento da } \\
\text { Inspetoria de } \\
\text { Educação Física e } \\
\text { Esportes do } \\
\text { município de } \\
\text { Limeira. }\end{array}$ \\
\hline $\begin{array}{l}30 \text { de } \\
\text { julho de } \\
1970\end{array}$ & $\begin{array}{l}\text { Governo do } \\
\text { Estado de } \\
\text { São Paulo }\end{array}$ & Ato Executivo & Decreto & do dia & $\begin{array}{l}\text { Dispõe sobre o } \\
\text { funcionamento da } \\
\text { Inspetoria de } \\
\text { Educação Física e } \\
\text { Esportes do } \\
\text { município de } \\
\text { Oswaldo Cruz. }\end{array}$ \\
\hline $\begin{array}{l}31 \text { de } \\
\text { julho de } \\
1970\end{array}$ & $\begin{array}{l}\text { Assembleia } \\
\text { Legislativa } \\
\text { de São } \\
\text { Paulo }\end{array}$ & $\begin{array}{l}\text { Pronunciamen } \\
\text { to }\end{array}$ & Discussão & & $\begin{array}{l}\text { Anúncio de que a } \\
\text { Caixa Econômica } \\
\text { fará testes iniciais } \\
\text { da Loteria } \\
\text { Esportiva em São } \\
\text { Paulo. Deputado } \\
\text { Pedro Paschoal. }\end{array}$ \\
\hline $\begin{array}{l}31 \text { de } \\
\text { julho de } \\
1970\end{array}$ & \begin{tabular}{|l|} 
Câmara \\
Municipal de \\
São Paulo \\
\end{tabular} & $\begin{array}{l}\text { Pronunciamen } \\
\text { to }\end{array}$ & Votação & & $\begin{array}{l}\text { Fala favorável ao o } \\
\text { "Projeto } \\
\text { Volkswagen". }\end{array}$ \\
\hline $\begin{array}{l}01 \text { de } \\
\text { agosto } \\
\text { de } 1970\end{array}$ & $\begin{array}{l}\text { Assembleia } \\
\text { Legislativa } \\
\text { de São } \\
\text { Paulo }\end{array}$ & $\begin{array}{l}\text { Pronunciamen } \\
\text { to }\end{array}$ & Homenagem & & $\begin{array}{l}\text { Fala enaltecendo o } \\
\text { espírito esportivo } \\
\text { do prefeito Paulo } \\
\text { Maluf por batizar } \\
\text { novo viaduto como } \\
\text { Guadalajara, em } \\
\text { homenagem ao } \\
\text { povo mexicano que } \\
\text { sediou a Copa do } \\
\text { Mundo. }\end{array}$ \\
\hline $\begin{array}{l}04 \text { de } \\
\text { agosto } \\
\text { de } 1970\end{array}$ & $\begin{array}{l}\text { Assembleia } \\
\text { Legislativa } \\
\text { de São } \\
\text { Paulo }\end{array}$ & Moção & Ao executivo & 63 & $\begin{array}{l}\text { Moção da Alesp ao } \\
\text { Presidente da } \\
\text { República, General } \\
\text { Médici, para que } \\
\text { de apoio a União } \\
\text { brasileira de } \\
\text { Paraquedismo } \\
\text { para custear os } 5\end{array}$ \\
\hline
\end{tabular}




\begin{tabular}{|c|c|c|c|c|c|}
\hline & & & & & $\begin{array}{l}\text { melhores atletas } \\
\text { que foram } \\
\text { classificados para } \\
\text { representar o país } \\
\text { em campeonato } \\
\text { mundial. }\end{array}$ \\
\hline $\begin{array}{l}06 \text { de } \\
\text { agosto } \\
\text { de } 1970\end{array}$ & $\begin{array}{l}\text { Assembleia } \\
\text { Legislativa } \\
\text { de São } \\
\text { Paulo } \\
\end{array}$ & $\begin{array}{l}\text { Pronunciamen } \\
\text { to }\end{array}$ & Homenagem & & $\begin{array}{l}\text { Wadih Helu fala do } \\
\text { encontro de } \\
\text { esportistas na } \\
\text { Universidade de } \\
\text { Brasília. Faz } \\
\text { discurso sobre } \\
\text { mocidade, } \\
\text { entusiasmo e } \\
\text { brasilidade. }\end{array}$ \\
\hline $\begin{array}{l}06 \text { de } \\
\text { agosto } \\
\text { de } 1970\end{array}$ & $\begin{array}{l}\text { Assembleia } \\
\text { Legislativa } \\
\text { de São } \\
\text { Paulo } \\
\end{array}$ & $\begin{array}{l}\text { Pronunciamen } \\
\text { to }\end{array}$ & Ao executivo & & $\begin{array}{l}\text { Devido a demanda } \\
\text { do paraquedismo, } \\
\text { deputado Jamil } \\
\text { Gadia pede a } \\
\text { criação de linha de } \\
\text { ônibus São Paulo - } \\
\text { Campinas. } \\
\end{array}$ \\
\hline $\begin{array}{l}06 \text { de } \\
\text { agosto } \\
\text { de } 1970\end{array}$ & $\begin{array}{l}\text { Assembleia } \\
\text { Legislativa } \\
\text { de São } \\
\text { Paulo } \\
\end{array}$ & $\begin{array}{l}\text { Pronunciamen } \\
\text { to }\end{array}$ & Ao executivo & & $\begin{array}{l}\text { deputado Jamil } \\
\text { Gadia fala sobre o } \\
\text { campeonato de } \\
\text { paraquedismo. }\end{array}$ \\
\hline $\begin{array}{l}07 \text { de } \\
\text { agosto } \\
\text { de } 1970\end{array}$ & $\begin{array}{l}\text { Assembleia } \\
\text { Legislativa } \\
\text { de São } \\
\text { Paulo } \\
\end{array}$ & $\begin{array}{l}\text { Pronunciamen } \\
\text { to }\end{array}$ & Discussão & & $\begin{array}{l}\text { Discussão no } \\
\text { plenário sobre a } \\
\text { Loteria Esportiva. }\end{array}$ \\
\hline $\begin{array}{l}07 \text { de } \\
\text { agosto } \\
\text { de } 1970\end{array}$ & $\begin{array}{l}\text { Assembleia } \\
\text { Legislativa } \\
\text { de São } \\
\text { Paulo } \\
\end{array}$ & $\begin{array}{l}\text { Pronunciamen } \\
\text { to }\end{array}$ & Discussão & & $\begin{array}{l}\text { Deputado Solon } \\
\text { Borges faz apelo } \\
\text { pela união dos } \\
\text { poderes púbicos e } \\
\text { da iniciativa } \\
\text { privada para } \\
\text { incentivo ao } \\
\text { esporte para que } \\
\text { se alcance } \\
\text { resultado nas } \\
\text { Olimpíadas } \\
\text { parecido com o da } \\
\text { Copa do Mundo. } \\
\end{array}$ \\
\hline $\begin{array}{l}07 \text { de } \\
\text { agosto } \\
\text { de } 1970\end{array}$ & $\begin{array}{l}\text { Câmara } \\
\text { Municipal de } \\
\text { São Paulo }\end{array}$ & $\begin{array}{l}\text { Pronunciamen } \\
\text { to }\end{array}$ & Discussão & & $\begin{array}{l}\text { Discussão sobre } \\
\text { os méritos do } \\
\text { "Projeto } \\
\text { Volkswagen" e } \\
\text { sobre a falta de } \\
\text { cortesia do prefeito } \\
\text { em oferecer } \\
\text { apenas em caso } \\
\text { de vitória e de não } \\
\text { consultar a câmara } \\
\text { já num primeiro } \\
\text { momento. } \\
\end{array}$ \\
\hline $\begin{array}{l}08 \text { de } \\
\text { agosto } \\
\text { de } 1970\end{array}$ & $\begin{array}{l}\text { Assembleia } \\
\text { Legislativa } \\
\text { de São } \\
\text { Paulo }\end{array}$ & Requerimento & Ao Legislativo & 123 & $\begin{array}{l}\text { Indicação de votos } \\
\text { de congratulações } \\
\text { a mocidade } \\
\text { universitária } \\
\text { paulistana que }\end{array}$ \\
\hline
\end{tabular}




\begin{tabular}{|c|c|c|c|c|c|}
\hline & & & & & \begin{tabular}{|l} 
venceu os XXI \\
jogos \\
Universitários \\
Brasileiros.
\end{tabular} \\
\hline $\begin{array}{l}18 \text { de } \\
\text { agosto } \\
\text { de } 1970\end{array}$ & \begin{tabular}{|l} 
Câmara \\
Municipal de \\
São Paulo \\
\end{tabular} & $\begin{array}{l}\text { Pronunciamen } \\
\text { to }\end{array}$ & Discussão & & $\begin{array}{l}\text { Vereador Brasil } \\
\text { Vita fala da Loteria } \\
\text { Esportiva. Fala da } \\
\text { preocupação de } \\
\text { que crianças e os } \\
\text { menos afortunados } \\
\text { estão jogando e } \\
\text { comenta sobre } \\
\text { editorial do "jornal } \\
\text { da Tarde" do dia } \\
\text { anterior, que fez a } \\
\text { matéria "O país } \\
\text { transformado em u } \\
\text { vasto Cassino". } \\
\end{array}$ \\
\hline $\begin{array}{l}19 \mathrm{DE} \\
\text { AGOST } \\
\text { O DE } \\
1970 \\
\end{array}$ & $\begin{array}{l}\text { Câmara } \\
\text { Municipal de } \\
\text { São Paulo } \\
\end{array}$ & $\begin{array}{l}\text { Pronunciamen } \\
\text { to }\end{array}$ & & & $\begin{array}{l}\text { José Maria Marin } \\
\text { fala de visita de } \\
\text { comissão de } \\
\text { Campinas para } \\
\text { ratar sobre a } \\
\text { "urdidura de } \\
\text { tramas com } \\
\text { propósito e } \\
\text { sacrificar a } \\
\text { Associação Atlética } \\
\text { Ponte Preta". } \\
\end{array}$ \\
\hline $\begin{array}{l}21 \text { de } \\
\text { agosto } \\
\text { de } 1970\end{array}$ & $\begin{array}{l}\text { Assembleia } \\
\text { Legislativa } \\
\text { de São } \\
\text { Paulo }\end{array}$ & Parecer & Moção & 104 & $\begin{array}{l}\text { Parecer sobre a } \\
\text { Moção } 5 \text { de } 70 \text { do } \\
\text { deputado } \\
\text { Archimedes } \\
\text { Lamoglia ao } \\
\text { presidente da } \\
\text { república para que } \\
\text { construa em São } \\
\text { Paulo monumento } \\
\text { dedicado a vitória } \\
\text { do Brasil na Copa } \\
\text { do Mundo. } \\
\text { Parecer } \\
\text { favorável/acolhime } \\
\text { nto da moção. } \\
\end{array}$ \\
\hline $\begin{array}{l}21 \text { de } \\
\text { agosto } \\
\text { de } 1970\end{array}$ & $\begin{array}{l}\text { Assembleia } \\
\text { Legislativa } \\
\text { de São } \\
\text { Paulo }\end{array}$ & Parecer & Moção & 105 & $\begin{array}{l}\text { Parecer sobre } \\
\text { Moção } 7 \text { de } 70 \text { do } \\
\text { deputado Mario } \\
\text { Teles que pede ao } \\
\text { presidente da } \\
\text { república para que } \\
\text { os clubes } \\
\text { esportivos } \\
\text { amadores possam } \\
\text { ser distribuidores } \\
\text { de bilhetes da } \\
\text { loteria esportiva. } \\
\text { Parecer } \\
\text { favorável/acolhime } \\
\text { nto da moção. }\end{array}$ \\
\hline
\end{tabular}




\begin{tabular}{|c|c|c|c|c|c|}
\hline $\begin{array}{l}21 \text { de } \\
\text { agosto } \\
\text { de } 1970\end{array}$ & $\begin{array}{l}\text { Assembleia } \\
\text { Legislativa } \\
\text { de São } \\
\text { Paulo }\end{array}$ & Parecer & Moção & 107 & \begin{tabular}{|l} 
Parecer sobre \\
Moção 14 de 70 do \\
deputado Duele \\
Sales Cunha Braga \\
que pede ao \\
prefeito da capital \\
do estado que \\
instale Museu do \\
Exorte no Salão \\
Nobre do Estádio \\
Municipal do \\
Pacaembu. \\
Parecer \\
favorável/acolhime \\
nto da moção.
\end{tabular} \\
\hline $\begin{array}{l}21 \text { de } \\
\text { agosto } \\
\text { de } 1970\end{array}$ & $\begin{array}{l}\text { Assembleia } \\
\text { Legislativa } \\
\text { de São } \\
\text { Paulo } \\
\end{array}$ & Parecer & Moção & 108 & $\begin{array}{l}\text { Parecer sobre } \\
\text { Moção da Alesp ao } \\
\text { Presidente da } \\
\text { República, General } \\
\text { Médici, para que } \\
\text { de apoio a União } \\
\text { brasileira de } \\
\text { Paraquedismo } \\
\text { para custear os } 5 \\
\text { melhores atletas } \\
\text { que foram } \\
\text { classificados para } \\
\text { representar o país } \\
\text { em campeonato } \\
\text { mundial. Parecer } \\
\text { favorável/acolhime } \\
\text { nto da moção. } \\
\end{array}$ \\
\hline $\begin{array}{l}27 \text { de } \\
\text { agosto } \\
\text { de } 1970\end{array}$ & $\begin{array}{l}\text { Assembleia } \\
\text { Legislativa } \\
\text { de São } \\
\text { Paulo } \\
\end{array}$ & Parecer & Moção & 143 & $\begin{array}{l}\text { Parecer sobre a } \\
\text { Moção } 18 \text { do } \\
\text { deputado Shiro } \\
\text { Kiono que pede } \\
\text { que o Presidente } \\
\text { da República pele } \\
\text { ao Comitê } \\
\text { Olímpico } \\
\text { Internacional no } \\
\text { sentido de solicitar } \\
\text { que a 12o } \\
\text { Olimpíada seja } \\
\text { realizada no Brasil, } \\
\text { na cidade de São } \\
\text { Paulo. Parecer } \\
\text { favorável/acolhime } \\
\text { nto da moção. }\end{array}$ \\
\hline $\begin{array}{l}27 \text { de } \\
\text { agosto } \\
\text { de } 1970\end{array}$ & $\begin{array}{l}\text { Assembleia } \\
\text { Legislativa } \\
\text { de São } \\
\text { Paulo } \\
\end{array}$ & Parecer & Moção & 144 & $\begin{array}{l}\text { parecer sobre a } \\
\text { Moção } 17 \text { do } \\
\text { deputado Dulce } \\
\text { Sales Cunha Braga } \\
\text { apelando ao } \\
\text { presidente da } \\
\text { Federação Paulista } \\
\text { de Futebol que } \\
\text { peça aos seus } \\
\text { clubes filiados que } \\
\text { coloquem em suas } \\
\end{array}$ \\
\hline
\end{tabular}




\begin{tabular}{|c|c|c|c|c|c|}
\hline & & & & & $\begin{array}{l}\text { praças de esporte } \\
\text { algum alusivo a } \\
\text { conquista do Tri } \\
\text { Campeonato pela } \\
\text { seleção brasileira. } \\
\text { Parecer } \\
\text { favorável/acolhime } \\
\text { nto da moção. }\end{array}$ \\
\hline $\begin{array}{l}27 \text { de } \\
\text { agosto } \\
\text { de } 1970\end{array}$ & $\begin{array}{l}\text { Assembleia } \\
\text { Legislativa } \\
\text { de São } \\
\text { Paulo } \\
\end{array}$ & Parecer & Moção & 145 & $\begin{array}{l}\text { Parecer sobre a } \\
\text { Moção } 15 \text { do } \\
\text { deputado Ary Silva } \\
\text { ao Ministro da } \\
\text { Educação, de onde } \\
\text { o ministério é } \\
\text { responsável por } \\
\text { esta regulação, } \\
\text { que determine que } \\
\text { os selecionados } \\
\text { brasileiros de todas } \\
\text { as modalidades } \\
\text { usem em seus } \\
\text { uniforme o nome } \\
\text { do Brasil, e não } \\
\text { mais o das } \\
\text { entidades aos } \\
\text { quais são filiados. } \\
\text { Parecer } \\
\text { favorável/acolhime } \\
\text { nto da moção. }\end{array}$ \\
\hline $\begin{array}{l}28 \text { de } \\
\text { agosto } \\
\text { de } 1970\end{array}$ & $\begin{array}{l}\text { Assembleia } \\
\text { Legislativa } \\
\text { de São } \\
\text { Paulo }\end{array}$ & Ata & Reunião & Comissão & $\begin{array}{l}\text { Ata da reunião da } \\
\text { Comissão de } \\
\text { Cultura, Esporte e } \\
\text { Turismo, citandos } \\
\text { os pareceres do } \\
\text { dia anterior. } \\
\end{array}$ \\
\hline $\begin{array}{l}29 \text { de } \\
\text { agosto } \\
\text { de } 1970\end{array}$ & $\begin{array}{l}\text { Assembleia } \\
\text { Legislativa } \\
\text { de São } \\
\text { Paulo } \\
\end{array}$ & Ata & Reunião & Comissão & \begin{tabular}{|l|} 
Ata da reunião da \\
Comissão de \\
Cultura, Esporte e \\
Turismo, citandos \\
os pareceres do \\
dia anterior. \\
\end{tabular} \\
\hline $\begin{array}{l}13 \text { de } \\
\text { outubro } \\
\text { de } 1970\end{array}$ & $\begin{array}{l}\text { Câmara } \\
\text { Municipal de } \\
\text { São Paulo } \\
\end{array}$ & $\begin{array}{l}\text { Pronunciamen } \\
\text { to }\end{array}$ & Homenagem & & $\begin{array}{l}\text { Homenagem pela } \\
\text { atuação no campo } \\
\text { de Emerson } \\
\text { Fittipaldi em } \\
\text { competição no } \\
\text { Estados Unidos. } \\
\end{array}$ \\
\hline $\begin{array}{l}21 \text { de } \\
\text { outubro } \\
\text { de } 1970\end{array}$ & $\begin{array}{l}\text { Câmara } \\
\text { Municipal de } \\
\text { São Paulo } \\
\end{array}$ & $\begin{array}{l}\text { Pronunciamen } \\
\text { to }\end{array}$ & Ao executivo & & $\begin{array}{l}\text { Vereadora } \\
\text { Theodosina Ribeiro } \\
\text { critica a prova de } \\
\text { concurso realizada } \\
\text { no final de semana } \\
\text { anterior para } \\
\text { ingresso no } \\
\text { magistério } \\
\text { municipal, visto } \\
\text { que tiveram na } \\
\text { prova questões } \\
\text { sobre futebol, coisa } \\
\text { que fora a Copa do }\end{array}$ \\
\hline
\end{tabular}




\begin{tabular}{|c|c|c|c|c|c|}
\hline & & & & & $\begin{array}{l}\text { Mundo, não é de } \\
\text { interesse da } \\
\text { maioria das } \\
\text { mulheres, gerando } \\
\text { assim uma } \\
\text { desvantagem } \\
\text { injusta. }\end{array}$ \\
\hline $\begin{array}{l}23 \text { de } \\
\text { outubro } \\
\text { de } 1970\end{array}$ & $\begin{array}{l}\text { Câmara } \\
\text { Municipal de } \\
\text { São Paulo }\end{array}$ & $\begin{array}{l}\text { Pronunciamen } \\
\text { to }\end{array}$ & Ao executivo & & $\begin{array}{l}\text { Vereador Samir } \\
\text { Achoa diz que a } \\
\text { pergunta sobre } \\
\text { futebol no } \\
\text { concurso para } \\
\text { ingresso no } \\
\text { magistério foi uma } \\
\text { homenagem dos } \\
\text { brasileiros ao povo } \\
\text { mexicano pelo } \\
\text { tratamento aos } \\
\text { brasileiros durante } \\
\text { a Copa. }\end{array}$ \\
\hline $\begin{array}{l}06 \text { de } \\
\text { novembr } \\
\text { o de } \\
1970\end{array}$ & $\begin{array}{l}\text { Assembleia } \\
\text { Legislativa } \\
\text { de São } \\
\text { Paulo }\end{array}$ & $\begin{array}{l}\text { Pronunciamen } \\
\text { to }\end{array}$ & Discussão & & $\begin{array}{l}\text { Deputado Wadih } \\
\text { Helu faz } \\
\text { questionamento ao } \\
\text { prefeito de São } \\
\text { Paulo sobre as } \\
\text { questões sobre } \\
\text { futebol no } \\
\text { concurso para } \\
\text { ingresso no } \\
\text { magistério. }\end{array}$ \\
\hline $\begin{array}{l}21 \text { de } \\
\text { novembr } \\
\text { o de } \\
1970\end{array}$ & $\begin{array}{l}\text { Assembleia } \\
\text { Legislativa } \\
\text { de São } \\
\text { Paulo }\end{array}$ & $\begin{array}{l}\text { Pronunciamen } \\
\text { to }\end{array}$ & Discussão & & $\begin{array}{l}\text { Deputado Solon } \\
\text { Borges faz } \\
\text { discurso sobre } \\
\text { combate a } \\
\text { entorpecentes } \\
\text { através de, entre } \\
\text { outras coisas, do } \\
\text { esporte. }\end{array}$ \\
\hline $\begin{array}{l}25 \text { de } \\
\text { novembr } \\
\text { o de } \\
1970\end{array}$ & $\begin{array}{l}\text { Assembleia } \\
\text { Legislativa } \\
\text { de São } \\
\text { Paulo } \\
\end{array}$ & Parecer & Moção & 600 & $\begin{array}{l}\text { Parecer sobre a } \\
\text { Moção 160, do } \\
\text { deputado Abil Nab } \\
\text { Chedid, que faz } \\
\text { apela ao Ministro } \\
\text { da Educação para } \\
\text { conceder "medalha } \\
\text { do Mérito } \\
\text { Esportivo" aos } \\
\text { jornalistas e } \\
\text { dirigentes } \\
\text { esportivos } \\
\text { responsáveis pelo } \\
\text { campeonato Dente } \\
\text { de Leite, Ivo } \\
\text { Gorgulho, Ely } \\
\text { Coimbra e Roberto } \\
\text { Petri. Parecer } \\
\text { favorável/acolhime } \\
\text { nto da moção. }\end{array}$ \\
\hline
\end{tabular}




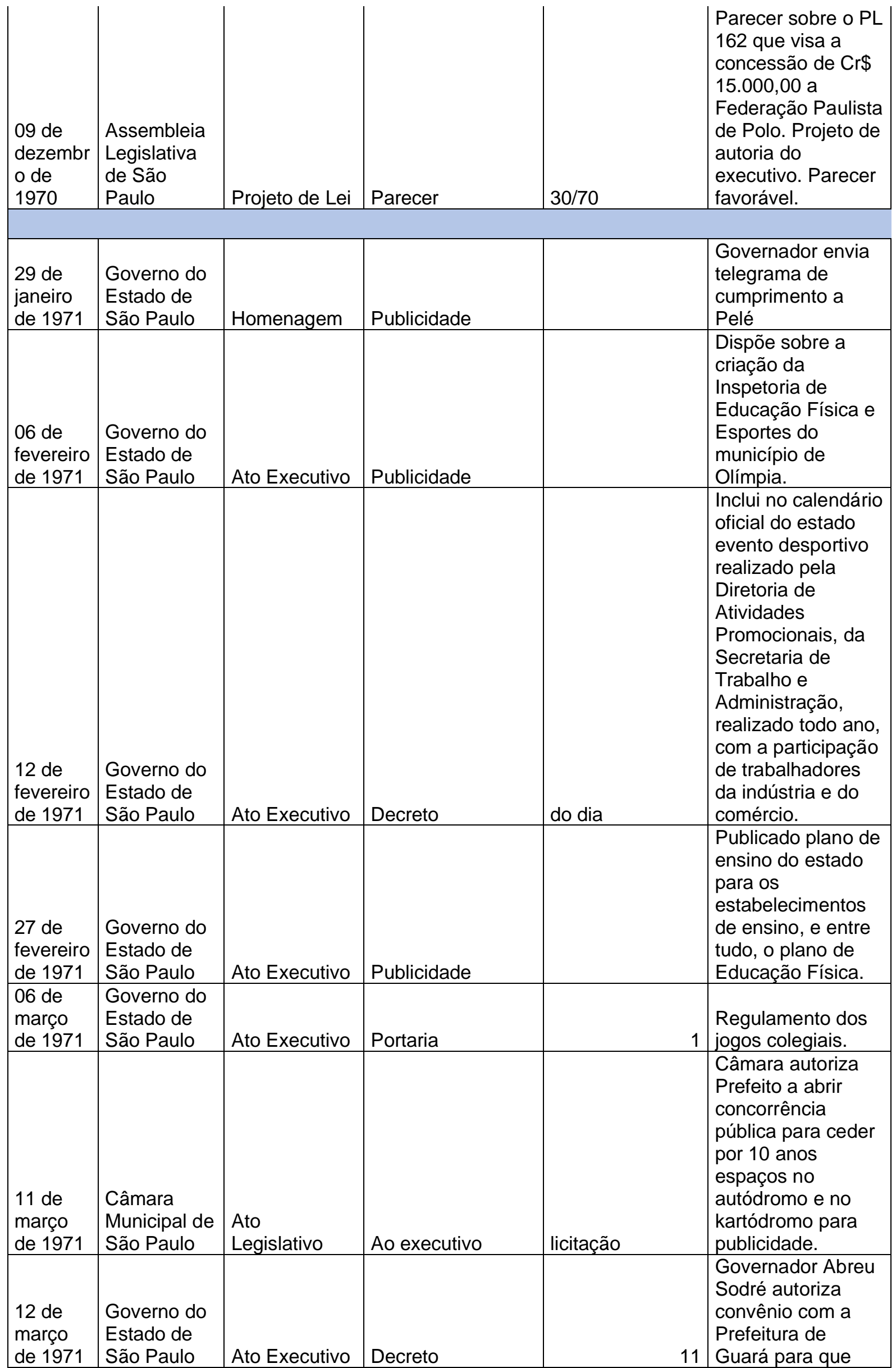




\begin{tabular}{|c|c|c|c|c|c|}
\hline & & & & & $\begin{array}{l}\text { esta construa } \\
\text { piscina em terreno } \\
\text { do estado. }\end{array}$ \\
\hline $\begin{array}{l}12 \text { de } \\
\text { março } \\
\text { de } 1971\end{array}$ & $\begin{array}{l}\text { Governo do } \\
\text { Estado de } \\
\text { São Paulo }\end{array}$ & Ato Executivo & Decreto & 11 & $\begin{array}{l}\text { Governador Abreu } \\
\text { Sodré autoriza } \\
\text { convênio com a } \\
\text { Prefeitura de Mogi } \\
\text { das Cruzes para } \\
\text { que esta construa } \\
\text { praça de esportes } \\
\text { em terreno do } \\
\text { estado. } \\
\end{array}$ \\
\hline $\begin{array}{l}12 \text { de } \\
\text { março } \\
\text { de } 1971\end{array}$ & $\begin{array}{l}\text { Governo do } \\
\text { Estado de } \\
\text { São Paulo }\end{array}$ & Ato Executivo & Decreto & 11 & $\begin{array}{l}\text { Governador Abreu } \\
\text { Sodré autoriza } \\
\text { convênio com a } \\
\text { Prefeitura de Nova } \\
\text { Aliança para que } \\
\text { esta construa } \\
\text { praça de esportes } \\
\text { em terreno do } \\
\text { estado. }\end{array}$ \\
\hline $\begin{array}{l}12 \text { de } \\
\text { março } \\
\text { de } 1971\end{array}$ & $\begin{array}{l}\text { Governo do } \\
\text { Estado de } \\
\text { São Paulo }\end{array}$ & Ato Executivo & Decreto & 11 & $\begin{array}{l}\text { Governador Abreu } \\
\text { Sodré autoriza } \\
\text { convênio com a } \\
\text { Prefeitura de } \\
\text { Regente Feijó para } \\
\text { que esta construa } \\
\text { praça de esportes } \\
\text { em terreno do } \\
\text { estado. }\end{array}$ \\
\hline $\begin{array}{l}12 \text { de } \\
\text { março } \\
\text { de } 1971\end{array}$ & $\begin{array}{l}\text { Governo do } \\
\text { Estado de } \\
\text { São Paulo }\end{array}$ & Ato Executivo & Decreto & 11 & $\begin{array}{l}\text { Governador Abreu } \\
\text { Sodré autoriza } \\
\text { convênio com a } \\
\text { Prefeitura de } \\
\text { Ribeirão Branco } \\
\text { para que esta } \\
\text { construa praça de } \\
\text { esportes em } \\
\text { terreno do estado. }\end{array}$ \\
\hline $\begin{array}{l}12 \text { de } \\
\text { março } \\
\text { de } 1971\end{array}$ & $\begin{array}{l}\text { Governo do } \\
\text { Estado de } \\
\text { São Paulo }\end{array}$ & Ato Executivo & Decreto & 11 & $\begin{array}{l}\text { Governador Abreu } \\
\text { Sodré autoriza } \\
\text { convênio com a } \\
\text { Prefeitura de São } \\
\text { João do Pau D'alho } \\
\text { para que esta } \\
\text { construa praça de } \\
\text { esportes em } \\
\text { terreno do estado. } \\
\end{array}$ \\
\hline $\begin{array}{l}18 \text { de } \\
\text { março e } \\
1971\end{array}$ & $\begin{array}{l}\text { Governo do } \\
\text { Estado de } \\
\text { São Paulo }\end{array}$ & Ato Executivo & Nomeação & publicidade & $\begin{array}{l}\text { Assume o Cargo } \\
\text { de Secretário da } \\
\text { Secretaria de } \\
\text { Cultura, Esportes e } \\
\text { Turismo o Sr. } \\
\text { Pedro Magalhães } \\
\text { Padilha } \\
\end{array}$ \\
\hline $\begin{array}{l}23 \text { de } \\
\text { março } \\
\text { de } 1971\end{array}$ & $\begin{array}{l}\text { Governo do } \\
\text { Estado de } \\
\text { São Paulo }\end{array}$ & Ato Executivo & Nomeação & publicidade & $\begin{array}{l}\text { Retorno de Silvyo } \\
\text { Magalhães Padilha } \\
\text { ao DEFE. } \\
\text { Proposição de } \\
\text { trazer novamente }\end{array}$ \\
\hline
\end{tabular}




\begin{tabular}{|c|c|c|c|c|c|}
\hline & & & & & $\begin{array}{l}\text { técnicos } \\
\text { internacionais para } \\
\text { incentivo ao } \\
\text { esporte. }\end{array}$ \\
\hline $\begin{array}{l}26 \text { de } \\
\text { março } \\
\text { de } 1971\end{array}$ & $\begin{array}{l}\text { Governo do } \\
\text { Estado de } \\
\text { São Paulo }\end{array}$ & Ato Executivo & Nomeação & publicidade & $\begin{array}{l}\text { Padilha faz } \\
\text { discurso dizendo } \\
\text { que transformará o } \\
\text { DEFE em piloto } \\
\text { para o país inteiro. }\end{array}$ \\
\hline $\begin{array}{l}26 \text { de } \\
\text { março } \\
\text { de } 1971\end{array}$ & $\begin{array}{l}\text { Governo do } \\
\text { Estado de } \\
\text { São Paulo }\end{array}$ & & Publicidade & & $\begin{array}{l}\text { Governador recebe } \\
\text { dirigentes do } \\
\text { basquete } \\
\text { brasileiro. }\end{array}$ \\
\hline $\begin{array}{l}30 \text { de } \\
\text { março } \\
\text { de } 1971\end{array}$ & $\begin{array}{l}\text { Câmara } \\
\text { Municipal de } \\
\text { São Paulo }\end{array}$ & $\begin{array}{l}\text { Pronunciamen } \\
\text { to }\end{array}$ & Homenagem & & $\begin{array}{l}\text { Visita a Câmara do } \\
\text { Almirante Paulo } \\
\text { Martins da } \\
\text { Marinha, ligado ao } \\
\text { Basquete. }\end{array}$ \\
\hline $\begin{array}{l}01 \text { de } \\
\text { abril de } \\
1971\end{array}$ & $\begin{array}{l}\text { Governo do } \\
\text { Estado de } \\
\text { São Paulo }\end{array}$ & Ato Executivo & Publicidade & $\begin{array}{l}\text { Prestação de } \\
\text { Contas }\end{array}$ & \begin{tabular}{|l} 
Prestação de \\
Contas da \\
secretaria de \\
Cultura, Esportes e \\
Turismo sobre as \\
ações dos anos \\
anteriores.
\end{tabular} \\
\hline $\begin{array}{l}02 \text { de } \\
\text { abril de } \\
1971\end{array}$ & \begin{tabular}{|l} 
Governo do \\
Estado de \\
São Paulo
\end{tabular} & Ato Executivo & Portaria & Alteração & $\begin{array}{l}\text { Altera Portaria do } \\
\text { Regulamento dos } \\
\text { jogos colegiais. }\end{array}$ \\
\hline $\begin{array}{l}03 \text { de } \\
\text { abril de } \\
1971 \\
\end{array}$ & \begin{tabular}{|l} 
Governo do \\
Estado de \\
São Paulo
\end{tabular} & Ato Executivo & Publicidade & DEFE & $\begin{array}{l}\text { Informações sobre } \\
\text { o Campeonato } \\
\text { Colegial de } 71 \text {. }\end{array}$ \\
\hline $\begin{array}{l}13 \text { de } \\
\text { abril de } \\
1971 \\
\end{array}$ & $\begin{array}{l}\text { Governo do } \\
\text { Estado de } \\
\text { São Paulo } \\
\end{array}$ & Ato Executivo & Publicidade & $\begin{array}{l}\text { Secretaria } \\
\text { Trabalho }\end{array}$ & $\begin{array}{l}\text { Secretaria do } \\
\text { Trabalho diz que } \\
\text { promoverá } \\
\text { incremento ao } \\
\text { esporte e marca } \\
\text { partida entre São } \\
\text { Paulo e Paraná no } \\
\text { próximo } 1 \text { de maio. }\end{array}$ \\
\hline $\begin{array}{l}15 \text { de } \\
\text { abril de } \\
1971\end{array}$ & $\begin{array}{l}\text { Governo do } \\
\text { Estado de } \\
\text { São Paulo }\end{array}$ & Ato Executivo & Publicidade & & $\begin{array}{l}\text { Governo anuncia } \\
\text { esforços conjuntos } \\
\text { entre Estado e } \\
\text { Capital para } \\
\text { trabalho no } \\
\text { esporte, após } \\
\text { reunião de Silvyo } \\
\text { Magalhães Padilha } \\
\text { e Paulo Machado } \\
\text { de Carvalho, } \\
\text { secretário de } \\
\text { Esportes do } \\
\text { município. }\end{array}$ \\
\hline $\begin{array}{l}16 \text { de } \\
\text { abril de } \\
1971\end{array}$ & $\begin{array}{l}\text { Governo do } \\
\text { Estado de } \\
\text { São Paulo }\end{array}$ & Ato Executivo & Publicidade & & $\begin{array}{l}\text { Anúncios de Jogos } \\
\text { Regionais no } \\
\text { Interior. }\end{array}$ \\
\hline $\begin{array}{l}17 \text { de } \\
\text { abril de } \\
1971\end{array}$ & $\begin{array}{l}\text { Governo do } \\
\text { Estado de } \\
\text { São Paulo }\end{array}$ & Ato Executivo & Portaria & 4 & $\begin{array}{l}\text { Dispõe sobre o } \\
\text { registro de atletas. }\end{array}$ \\
\hline
\end{tabular}




\begin{tabular}{|c|c|c|c|c|c|}
\hline $\begin{array}{l}20 \text { de } \\
\text { abril de } \\
1971\end{array}$ & $\begin{array}{l}\text { Assembleia } \\
\text { Legislativa } \\
\text { de São } \\
\text { Paulo } \\
\end{array}$ & $\begin{array}{l}\text { Pronunciamen } \\
\text { to }\end{array}$ & Ao executivo & & $\begin{array}{l}\text { Deputado Hatiro } \\
\text { Shimomoto pede } \\
\text { ao Governador a } \\
\text { criação do Vale do } \\
\text { Esporte e Cultura } \\
\text { nas Margens do } \\
\text { Tiete, beneficiando } \\
\text { os municípios de } \\
\text { São Paulo e } \\
\text { Guarulhos. }\end{array}$ \\
\hline \begin{tabular}{|l}
21 de \\
abril de \\
1971 \\
\end{tabular} & $\begin{array}{l}\text { Câmara } \\
\text { Municipal de } \\
\text { São Paulo } \\
\end{array}$ & Indicação & Ao executivo & & $\begin{array}{l}\text { Vereador Vicente } \\
\text { Almeida faz } \\
\text { indicação ao } \\
\text { Prefeito para que } \\
\text { proceda com } \\
\text { estudos para a } \\
\text { criação de praça } \\
\text { de esportes no } \\
\text { Jardim São Luiz. } \\
\end{array}$ \\
\hline $\begin{array}{l}04 \text { de } \\
\text { maio de } \\
1971 \\
\end{array}$ & $\begin{array}{l}\text { Câmara } \\
\text { Municipal de } \\
\text { São Paulo } \\
\end{array}$ & $\begin{array}{l}\text { Pronunciamen } \\
\text { to }\end{array}$ & Discussão & & $\begin{array}{l}\text { Vereador Samir } \\
\text { Achoa Faz crítica a } \\
\text { falta de critério da } \\
\text { Federação Paulista } \\
\text { de Futebol sobre a } \\
\text { venda de ingressos } \\
\text { dos jogos. } \\
\end{array}$ \\
\hline $\begin{array}{l}13 \text { de } \\
\text { maio de } \\
1971 \\
\end{array}$ & \begin{tabular}{|l} 
Assembleia \\
Legislativa \\
de São \\
Paulo \\
\end{tabular} & Projeto de Lei & Apresentação & $\mathrm{S} / \mathrm{n}$ & $\begin{array}{l}\text { Projeto de lei do } \\
\text { deputado Wadih } \\
\text { Helu sugere a } \\
\text { isenção tributária e } \\
\text { anistia aos clubes } \\
\text { esportivos do } \\
\text { estado. } \\
\end{array}$ \\
\hline $\begin{array}{l}28 \text { de } \\
\text { maio de } \\
1971 \\
\end{array}$ & \begin{tabular}{|l} 
Câmara \\
Municipal de \\
São Paulo \\
\end{tabular} & Requerimento & Homenagem & 88 & $\begin{array}{l}\text { Felicita a } \\
\text { Confederação } \\
\text { Brasileira e a } \\
\text { Paulista de } \\
\text { Basquete pela } \\
\text { vitória no } \\
\text { campeonato } \\
\text { mundial feminino. } \\
\end{array}$ \\
\hline \begin{tabular}{|l}
28 de \\
maio de \\
1971 \\
\end{tabular} & $\begin{array}{l}\text { Câmara } \\
\text { Municipal de } \\
\text { São Paulo }\end{array}$ & Requerimento & Homenagem & 89 & $\begin{array}{l}\text { Nota de júbilo ao } \\
\text { jornalista Emílio } \\
\text { Coleila pela sua } \\
\text { eleição como Vice } \\
\text { Presidente da } \\
\text { Associação } \\
\text { Internacional de } \\
\text { Imprensa } \\
\text { Esportiva. }\end{array}$ \\
\hline $\begin{array}{l}28 \text { de } \\
\text { maio de } \\
1971 \\
\end{array}$ & $\begin{array}{l}\text { Câmara } \\
\text { Municipal de } \\
\text { São Paulo } \\
\end{array}$ & $\begin{array}{l}\begin{array}{l}\text { Pronunciamen } \\
\text { to }\end{array} \\
\end{array}$ & Homenagem & & $\begin{array}{l}\text { Vereador Manoel } \\
\text { Sala fala do evento } \\
\text { de colocação da } \\
\text { pedra fundamental } \\
\text { no balneário do } \\
\text { Clube Esportivo da } \\
\text { Penha. } \\
\end{array}$ \\
\hline \begin{tabular}{|l|}
01 de \\
junho de \\
1971 \\
\end{tabular} & \begin{tabular}{|l|} 
Governo do \\
Estado de \\
São Paulo \\
\end{tabular} & & Publicidade & $\begin{array}{l}\text { Visita de } \\
\text { Delegação }\end{array}$ & $\begin{array}{l}\text { Visita de } \\
\text { delegação coreana }\end{array}$ \\
\hline
\end{tabular}




\begin{tabular}{|c|c|c|c|c|c|}
\hline & & & & & $\begin{array}{l}\text { de cestobolistas ao } \\
\text { governo. }\end{array}$ \\
\hline $\begin{array}{l}02 \text { de } \\
\text { junho de } \\
1971\end{array}$ & $\begin{array}{l}\text { Assembleia } \\
\text { Legislativa } \\
\text { de São } \\
\text { Paulo }\end{array}$ & Projeto de Lei & Apresentação & 119 & \begin{tabular}{|l} 
Projeto de lei do \\
deputado Wadih \\
Helu sugere a \\
isenção tributária e \\
anistia aos clubes \\
esportivos do \\
estado.
\end{tabular} \\
\hline $\begin{array}{l}02 \text { de } \\
\text { junho de } \\
1971\end{array}$ & $\begin{array}{l}\text { Assembleia } \\
\text { Legislativa } \\
\text { de São } \\
\text { Paulo }\end{array}$ & Requerimento & Homenagem & 170 & $\begin{array}{l}\text { Voto de } \\
\text { Congratulações } \\
\text { para o Grêmio } \\
\text { Esportivo São } \\
\text { Jorge pelos seus } \\
11 \text { anos. }\end{array}$ \\
\hline $\begin{array}{l}02 \text { de } \\
\text { junho de } \\
1971\end{array}$ & $\begin{array}{l}\text { Assembleia } \\
\text { Legislativa } \\
\text { de São } \\
\text { Paulo }\end{array}$ & Requerimento & Homenagem & 172 & $\begin{array}{l}\text { Voto de } \\
\text { Congratulações } \\
\text { para o } \\
\text { Confederação } \\
\text { Brasileira de } \\
\text { Basquetebol. } \\
\end{array}$ \\
\hline $\begin{array}{l}04 \text { de } \\
\text { junho de } \\
1971\end{array}$ & $\begin{array}{l}\text { Assembleia } \\
\text { Legislativa } \\
\text { de São } \\
\text { Paulo }\end{array}$ & $\begin{array}{l}\text { Pronunciamen } \\
\text { to }\end{array}$ & Homenagem & & $\begin{array}{l}\text { Deputado Ruy } \\
\text { Codo faz saudação } \\
\text { as atletas russas } \\
\text { que ganharam o } \\
\text { campeonato de } \\
\text { basquetebol e as } \\
\text { brasileiras pela } \\
\text { participação no } \\
\text { campeonato, } \\
\text { ocorrido no ginásio } \\
\text { do lbirapuera. }\end{array}$ \\
\hline $\begin{array}{l}08 \text { de } \\
\text { junho de } \\
1971\end{array}$ & $\begin{array}{l}\text { Câmara } \\
\text { Municipal de } \\
\text { São Paulo }\end{array}$ & $\begin{array}{l}\text { Pronunciamen } \\
\text { to }\end{array}$ & Discussão & & $\begin{array}{l}\text { Vereador Manoel } \\
\text { Sala fala da } \\
\text { importância dos } \\
\text { times de várzea e } \\
\text { da escassez de } \\
\text { lugares para a } \\
\text { prática do futebol } \\
\text { de várzea na } \\
\text { capital. }\end{array}$ \\
\hline $\begin{array}{l}08 \text { de } \\
\text { junho de } \\
1971\end{array}$ & $\begin{array}{l}\text { Assembleia } \\
\text { Legislativa } \\
\text { de São } \\
\text { Paulo } \\
\end{array}$ & $\begin{array}{l}\text { Pronunciamen } \\
\text { to }\end{array}$ & Discussão & & $\begin{array}{l}\text { Discussão sobre a } \\
\text { Loteria Esportiva. }\end{array}$ \\
\hline $\begin{array}{l}10 \text { de } \\
\text { junho de } \\
1971\end{array}$ & $\begin{array}{l}\text { Governo do } \\
\text { Estado de } \\
\text { São Paulo }\end{array}$ & Ato Executivo & Publicidade & & $\begin{array}{l}\text { Anúncio sobre } \\
\text { concessão de } \\
\text { Bolsas a } \\
\text { Estudantes } \\
\text { Esportistas. }\end{array}$ \\
\hline $\begin{array}{l}12 \text { de } \\
\text { junho de } \\
1971\end{array}$ & $\begin{array}{l}\text { Assembleia } \\
\text { Legislativa } \\
\text { de São } \\
\text { Paulo }\end{array}$ & Indicação & Ao executivo & 94 & \begin{tabular}{|l} 
Disputado Hatiro \\
Shimomoto indica \\
ao executivo que \\
seja criado Vale do \\
Esporte e Cultura \\
as margens do \\
Tiete
\end{tabular} \\
\hline
\end{tabular}




\begin{tabular}{|c|c|c|c|c|c|}
\hline $\begin{array}{l}16 \text { de } \\
\text { junho de } \\
1971\end{array}$ & $\begin{array}{l}\text { Câmara } \\
\text { Municipal de } \\
\text { São Paulo }\end{array}$ & $\begin{array}{l}\text { Pronunciamen } \\
\text { to }\end{array}$ & Discussão & & $\begin{array}{l}\text { Câmara discute a } \\
\text { intenção de Laudo } \\
\text { Natel reivindicar } \\
\text { São Paulo como } \\
\text { sede das } \\
\text { Olímpiadas de } \\
1980 .\end{array}$ \\
\hline $\begin{array}{l}16 \text { de } \\
\text { junho de } \\
1971 \\
\end{array}$ & \begin{tabular}{|l} 
Câmara \\
Municipal de \\
São Paulo \\
\end{tabular} & $\begin{array}{l}\text { Pronunciamen } \\
\text { to }\end{array}$ & Discussão & & $\begin{array}{l}\text { Discussão sobre a } \\
\text { necessidade de } \\
\text { integração entre } \\
\text { estado e prefeitura } \\
\text { para ações no } \\
\text { esporte, sobretudo } \\
\text { o escolar, no } \\
\text { sentido de se } \\
\text { formar atletas para } \\
\text { as Olímpiadas. } \\
\end{array}$ \\
\hline $\begin{array}{l}19 \text { de } \\
\text { junho de } \\
1971 \\
\end{array}$ & \begin{tabular}{|l} 
Assembleia \\
Legislativa \\
de São \\
Paulo \\
\end{tabular} & Projeto de Lei & Apresentação & 171 & $\begin{array}{l}\text { Dispões sobre a } \\
\text { criação dos jogos } \\
\text { universitários do } \\
\text { Estado, de autoria } \\
\text { do deputado Wadih } \\
\text { Helu }\end{array}$ \\
\hline $\begin{array}{l}22 \text { de } \\
\text { junho de } \\
1971 \\
\end{array}$ & $\begin{array}{l}\text { Governo do } \\
\text { Estado de } \\
\text { São Paulo }\end{array}$ & Ato Executivo & & DEFE & \begin{tabular}{|l|} 
Secretário de \\
esportes do estado \\
pede a todas as \\
organizações \\
amadoras suas \\
programações de \\
atividades nos \\
próximos 2 anos.
\end{tabular} \\
\hline $\begin{array}{l}30 \text { e } \\
\text { junho de } \\
1971\end{array}$ & $\begin{array}{l}\text { Assembleia } \\
\text { Legislativa } \\
\text { de São } \\
\text { Paulo }\end{array}$ & Indicação & Ao executivo & 836 & $\begin{array}{l}\text { Indicação do } \\
\text { deputado Hatiro } \\
\text { Shimomoto para } \\
\text { que o governo } \\
\text { construa Ginásio } \\
\text { de Esportes no } \\
\text { Município de } \\
\text { Guararapes. }\end{array}$ \\
\hline $\begin{array}{l}02 \text { de } \\
\text { julho de } \\
1971\end{array}$ & $\begin{array}{l}\text { Câmara } \\
\text { Municipal de } \\
\text { São Paulo }\end{array}$ & $\begin{array}{l}\text { Pronunciamen } \\
\text { to }\end{array}$ & Discussão & & \begin{tabular}{|l} 
Falas sobre o \\
torneio \\
internacional de \\
Basquetebol. \\
\end{tabular} \\
\hline \begin{tabular}{|l|}
03 de \\
julho de \\
1971 \\
\end{tabular} & $\begin{array}{l}\text { Governo do } \\
\text { Estado de } \\
\text { São Paulo } \\
\end{array}$ & Ato Executivo & Portaria & 112 & \begin{tabular}{|l|} 
Dispõe sobre os \\
Jogos Abertos do \\
Interior.
\end{tabular} \\
\hline $\begin{array}{l}03 \text { de } \\
\text { julho de } \\
1971\end{array}$ & $\begin{array}{l}\text { Governo do } \\
\text { Estado de } \\
\text { São Paulo }\end{array}$ & Ato Executivo & Publicidade & & $\begin{array}{l}\text { Início dos Jogos } \\
\text { Regionais em } \\
\text { cinco cidades } \\
\text { paulistas. }\end{array}$ \\
\hline $\begin{array}{l}21 \text { de } \\
\text { julho de } \\
1971 \\
\end{array}$ & $\begin{array}{l}\text { Governo do } \\
\text { Estado de } \\
\text { São Paulo } \\
\end{array}$ & Ato Executivo & Publicidade & & $\begin{array}{l}\text { Anúncio sobre } \\
\text { possível instalação } \\
\text { de Museu do } \\
\text { Esporte no estado, } \\
\text { aos moldes do de } \\
\text { Londres. }\end{array}$ \\
\hline \begin{tabular}{|l|}
21 de \\
julho de \\
1971 \\
\end{tabular} & $\begin{array}{l}\text { Governo do } \\
\text { Estado de } \\
\text { São Paulo }\end{array}$ & Ato Executivo & Publicidade & & $\begin{array}{l}\text { Anúncio de ações } \\
\text { para o programa } \\
\text { Recreação Esporte } \\
\text { do Trabalhador, } \\
\end{array}$ \\
\hline
\end{tabular}




\begin{tabular}{|c|c|c|c|c|c|}
\hline & & & & & $\begin{array}{l}\text { entre elas } \\
\text { empréstimo por } 30 \\
\text { anos do antigo } \\
\text { estádio da ferrovia }\end{array}$ \\
\hline \begin{tabular}{|l}
03 de \\
agosto \\
de 1971 \\
\end{tabular} & $\begin{array}{l}\text { Governo do } \\
\text { Estado de } \\
\text { São Paulo } \\
\end{array}$ & Ato Executivo & Publicidade & & \begin{tabular}{|l|} 
Realização de \\
evento esportivo \\
no município de \\
Batatais com mais \\
de mil educandos \\
para comemorar os \\
25 anos do \\
Instituto de \\
Menores daquela \\
cidade. \\
\end{tabular} \\
\hline \begin{tabular}{|l}
06 de \\
agosto \\
de 1971
\end{tabular} & $\begin{array}{l}\text { Assembleia } \\
\text { Legislativa } \\
\text { de São } \\
\text { Paulo } \\
\end{array}$ & $\begin{array}{l}\text { Pronunciamen } \\
\text { to }\end{array}$ & Discussão & & $\begin{array}{l}\text { Deputado José } \\
\text { Maria Marin faz } \\
\text { fala sobre as } \\
\text { conquistas do } \\
\text { Tênis Brasileiro. }\end{array}$ \\
\hline \begin{tabular}{|l}
11 de \\
agosto \\
de 1971 \\
\end{tabular} & $\begin{array}{l}\text { Governo do } \\
\text { Estado de } \\
\text { São Paulo } \\
\end{array}$ & Ato Executivo & Publicidade & & $\begin{array}{l}\text { Sindicato agradece } \\
\text { ao governador } \\
\text { cessão de terreno } \\
\text { para construção de } \\
\text { parque recreativo } \\
\text { esportivo do } \\
\text { trabalhador. } \\
\end{array}$ \\
\hline \begin{tabular}{|l|}
12 de \\
agosto \\
de 1971 \\
\end{tabular} & \begin{tabular}{|l|} 
Governo do \\
Estado de \\
São Paulo \\
\end{tabular} & Ato Executivo & Publicidade & & $\begin{array}{l}\text { Prossegue o } \\
\text { torneio em Batatais }\end{array}$ \\
\hline $\begin{array}{l}12 \text { de } \\
\text { agosto } \\
\text { de } 1971\end{array}$ & $\begin{array}{l}\text { Assembleia } \\
\text { Legislativa } \\
\text { de São } \\
\text { Paulo } \\
\end{array}$ & Requerimento & Homenagem & 377 & $\begin{array}{l}\text { Deputado Wadih } \\
\text { Helu sugere voto } \\
\text { de júbilo ao } \\
\text { SENAC pela XIV } \\
\text { Olimpíada Inter- } \\
\text { Escolar. } \\
\end{array}$ \\
\hline $\begin{array}{l}18 \text { de } \\
\text { agosto } \\
\text { de } 1971\end{array}$ & $\begin{array}{l}\text { Câmara } \\
\text { Municipal de } \\
\text { São Paulo } \\
\end{array}$ & $\begin{array}{l}\text { Pronunciamen } \\
\text { to }\end{array}$ & Discussão & & $\begin{array}{l}\text { Fala do vereador } \\
\text { Manoel Sala sobre } \\
\text { a falta de espaços } \\
\text { para a prática do } \\
\text { futebol de várzea. }\end{array}$ \\
\hline $\begin{array}{l}18 \text { de } \\
\text { agosto } \\
\text { de } 1971\end{array}$ & $\begin{array}{l}\text { Assembleia } \\
\text { Legislativa } \\
\text { de São } \\
\text { Paulo } \\
\end{array}$ & $\begin{array}{l}\text { Pronunciamen } \\
\text { to }\end{array}$ & & & $\begin{array}{l}\text { Deputado Abrahim } \\
\text { Dabus fala de } \\
\text { medida do } \\
\text { Ministério da } \\
\text { Educação que visa } \\
\text { definir o Esporte e } \\
\text { a Educação Física } \\
\text { como metas } \\
\text { prioritárias. }\end{array}$ \\
\hline $\begin{array}{l}19 \text { de } \\
\text { agosto } \\
\text { de } 1971\end{array}$ & $\begin{array}{l}\text { Assembleia } \\
\text { Legislativa } \\
\text { de São } \\
\text { Paulo } \\
\end{array}$ & $\begin{array}{l}\text { Pronunciamen } \\
\text { to }\end{array}$ & Ao executivo & & $\begin{array}{l}\text { Deputado Jayro } \\
\text { Maltoni indica ao } \\
\text { governador que } \\
\text { proceda com } \\
\text { estudos para a } \\
\text { instalação de praça } \\
\text { de esportes do } \\
\text { trabalhador no } \\
\text { município de } \\
\text { Jundiaí. }\end{array}$ \\
\hline
\end{tabular}




\begin{tabular}{|c|c|c|c|c|}
\hline $\begin{array}{l}21 \text { de } \\
\text { agosto } \\
\text { de } 1971 \\
\end{array}$ & $\begin{array}{l}\text { Governo do } \\
\text { Estado de } \\
\text { São Paulo } \\
\end{array}$ & Ato Executivo & Publicidade & $\begin{array}{l}\text { Instruções do } \\
\text { DEFE para desfile } \\
\text { da Semana da } \\
\text { Pátria no } \\
\text { Pacaembu. } \\
\end{array}$ \\
\hline $\begin{array}{l}24 \text { de } \\
\text { agosto } \\
\text { de } 1971 \\
\end{array}$ & $\begin{array}{l}\text { Câmara } \\
\text { Municipal de } \\
\text { São Paulo } \\
\end{array}$ & $\begin{array}{l}\text { Pronunciamen } \\
\text { to }\end{array}$ & Discussão & \begin{tabular}{|l|} 
Discussão sobre o \\
desempenho do \\
Brasil nos últimos \\
jogos Pan- \\
americanos. \\
\end{tabular} \\
\hline $\begin{array}{l}27 \text { de } \\
\text { agosto } \\
\text { de } 1971 \\
\end{array}$ & $\begin{array}{l}\text { Assembleia } \\
\text { Legislativa } \\
\text { de São } \\
\text { Paulo } \\
\end{array}$ & $\begin{array}{l}\text { Pronunciamen } \\
\text { to }\end{array}$ & Discussão & \begin{tabular}{|l|} 
Debate sobre \\
investimentos \\
públicos no \\
esporte, com \\
discordâncias ao \\
longo da seção. \\
\end{tabular} \\
\hline $\begin{array}{l}01 \text { de } \\
\text { setembr } \\
\text { o de } \\
1971 \\
\end{array}$ & $\begin{array}{l}\text { Governo do } \\
\text { Estado de } \\
\text { São Paulo }\end{array}$ & Ato Executivo & Publicidade & $\begin{array}{l}\text { Encerramento do } \\
\text { Campeonato } \\
\text { Colegial na } \\
\text { Semana da Pátria. }\end{array}$ \\
\hline $\begin{array}{l}01 \text { de } \\
\text { setembr } \\
\text { o de } \\
1971\end{array}$ & $\begin{array}{l}\text { Câmara } \\
\text { Municipal de } \\
\text { São Paulo }\end{array}$ & $\begin{array}{l}\text { Pronunciamen } \\
\text { to }\end{array}$ & Discussão & $\begin{array}{l}\text { Vereador Brasil } \\
\text { Vita fala do } \\
\text { editorial do Estado } \\
\text { de São Paulo } \\
\text { lançado em } 14 \text { de } \\
\text { agosto com o título } \\
\text { "Esporte e } \\
\text { Política". }\end{array}$ \\
\hline $\begin{array}{l}02 \text { de } \\
\text { setembr } \\
\text { o de } \\
1971 \\
\end{array}$ & $\begin{array}{l}\text { Assembleia } \\
\text { Legislativa } \\
\text { de São } \\
\text { Paulo } \\
\end{array}$ & $\begin{array}{l}\text { Pronunciamen } \\
\text { to }\end{array}$ & Discussão & \begin{tabular}{|l} 
Deputado José \\
Maria Marin fala do \\
Editorial do "diário \\
da Noite" que liga o \\
esporte ao civismo, \\
e faz registrar o \\
editorial nos Anais \\
da casa. \\
\end{tabular} \\
\hline $\begin{array}{l}10 \text { de } \\
\text { setembr } \\
\text { o de } \\
1971 \\
\end{array}$ & $\begin{array}{l}\text { Governo do } \\
\text { Estado de } \\
\text { São Paulo }\end{array}$ & Ato Executivo & Publicidade & \begin{tabular}{|l} 
Anúncio de \\
torneios a serem \\
realizados com 4 \\
mil educandos dos \\
Institutos de \\
Menores do \\
estado.
\end{tabular} \\
\hline $\begin{array}{l}17 \text { de } \\
\text { setembr } \\
\text { o de } \\
1971 \\
\end{array}$ & $\begin{array}{l}\text { Câmara } \\
\text { Municipal de } \\
\text { São Paulo } \\
\end{array}$ & $\begin{array}{l}\text { Pronunciamen } \\
\text { to }\end{array}$ & Discussão & $\begin{array}{l}\text { Vereador Manoel } \\
\text { Silva critica o fato } \\
\text { de que na } \\
\text { prefeitura existam } \\
\text { fiscais suficientes } \\
\text { para despejar } \\
\text { clubes esportivos } \\
\text { de áreas públicas, } \\
\text { mas, em tom } \\
\text { irônico, que não } \\
\text { tenha suficiente } \\
\text { para despejar } \\
\text { favela formada na } \\
\text { vila Prudente, que } \\
\text { é um "antro de } \\
\text { marginais e gente } \\
\text { desavergonhada". }\end{array}$ \\
\hline
\end{tabular}




\begin{tabular}{|c|c|c|c|c|c|}
\hline $\begin{array}{l}17 \text { de } \\
\text { setembr } \\
\text { o de } \\
1971\end{array}$ & \begin{tabular}{|l} 
Assembleia \\
Legislativa \\
de São \\
Paulo \\
\end{tabular} & $\begin{array}{l}\text { Pronunciamen } \\
\text { to }\end{array}$ & Discussão & & $\begin{array}{l}\text { Deputado Ary Silva } \\
\text { fala do "problema" } \\
\text { do esporte } \\
\text { universitário. }\end{array}$ \\
\hline $\begin{array}{l}22 \text { de } \\
\text { setembr } \\
\text { o de } \\
1971\end{array}$ & $\begin{array}{l}\text { Assembleia } \\
\text { Legislativa } \\
\text { de São } \\
\text { Paulo } \\
\end{array}$ & $\begin{array}{l}\text { Pronunciamen } \\
\text { to }\end{array}$ & Discussão & & $\begin{array}{l}\text { Deputado Jihel } \\
\text { Noda fala da } \\
\text { possível criação de } \\
\text { áreas esportivas } \\
\text { em torno do Tietê, } \\
\text { abrangendo São } \\
\text { Paulo e Guarulhos }\end{array}$ \\
\hline $\begin{array}{l}22 \text { de } \\
\text { setembr } \\
\text { o de } \\
1971\end{array}$ & $\begin{array}{l}\text { Assembleia } \\
\text { Legislativa } \\
\text { de São } \\
\text { Paulo } \\
\end{array}$ & $\begin{array}{l}\text { Pronunciamen } \\
\text { to }\end{array}$ & Discussão & & $\begin{array}{l}\text { Deputado Benedito } \\
\text { Matarazzo critica a } \\
\text { venda do Estádio } \\
\text { Martins Pereira, o } \\
\text { Formigão, do } \\
\text { Esporte Clube São } \\
\text { José (estádio } \\
\text { Público). }\end{array}$ \\
\hline $\begin{array}{l}24 \text { de } \\
\text { setembr } \\
\text { o de } \\
1971 \\
\end{array}$ & $\begin{array}{l}\text { Câmara } \\
\text { Municipal de } \\
\text { São Paulo } \\
\end{array}$ & $\begin{array}{l}\text { Pronunciamen } \\
\text { to }\end{array}$ & Discussão & & $\begin{array}{l}\text { Vereador Manoel } \\
\text { Silva fala } \\
\text { novamente sobre a } \\
\text { questão dos times } \\
\text { de várzea e o } \\
\text { esgotamento de } \\
\text { locais para prática } \\
\text { de jogos. } \\
\end{array}$ \\
\hline \begin{tabular}{|l|}
28 de \\
setembr \\
o de \\
1971 \\
\end{tabular} & \begin{tabular}{|l} 
Assembleia \\
Legislativa \\
de São \\
Paulo \\
\end{tabular} & $\begin{array}{l}\text { Pronunciamen } \\
\text { to }\end{array}$ & Discussão & & $\begin{array}{l}\text { Polêmica sobre } \\
\text { racismo com Pelé. }\end{array}$ \\
\hline \begin{tabular}{|l}
30 de \\
setembr \\
o de \\
1971 \\
\end{tabular} & $\begin{array}{l}\text { Assembleia } \\
\text { Legislativa } \\
\text { de São } \\
\text { Paulo } \\
\end{array}$ & $\begin{array}{l}\text { Pronunciamen } \\
\text { to }\end{array}$ & Discussão & & $\begin{array}{l}\text { Wadih Helu fala } \\
\text { sobre a "Semana } \\
\text { de Estudos sobre } \\
\text { Educação Física e } \\
\text { Esportes na área } \\
\text { Metropolitana de } \\
\text { São Paulo". }\end{array}$ \\
\hline \begin{tabular}{|l}
02 de \\
outubro \\
de 1971 \\
\end{tabular} & $\begin{array}{l}\text { Assembleia } \\
\text { Legislativa } \\
\text { de São } \\
\text { Paulo } \\
\end{array}$ & Requerimento & Homenagem & 569 & $\begin{array}{l}\text { Voto de louvor ao } \\
\text { Clube Monte } \\
\text { Líbano pela } \\
\text { realização do } \\
\text { Festival das Artes } \\
\text { Inter Clubes. } \\
\end{array}$ \\
\hline $\begin{array}{l}05 \text { de } \\
\text { outubro } \\
\text { de } 1971\end{array}$ & $\begin{array}{l}\text { Assembleia } \\
\text { Legislativa } \\
\text { de São } \\
\text { Paulo } \\
\end{array}$ & $\begin{array}{l}\text { Pronunciamen } \\
\text { to }\end{array}$ & Discussão & & $\begin{array}{l}\text { Fala do Deputado } \\
\text { Alex Freua Neto } \\
\text { sobre o slogan } \\
\text { "Ontem e Hoje, } \\
\text { Sempre Brasil", } \\
\text { esporte, juventude } \\
\text { e eugenia. }\end{array}$ \\
\hline $\begin{array}{l}06 \text { de } \\
\text { outubro } \\
\text { de } 1971\end{array}$ & $\begin{array}{l}\text { Câmara } \\
\text { Municipal de } \\
\text { São Paulo }\end{array}$ & $\begin{array}{l}\text { Pronunciamen } \\
\text { to }\end{array}$ & Discussão & & $\begin{array}{l}\text { Fala do vereador } \\
\text { Horacio Ortiz sobre } \\
\text { a "Semana de } \\
\text { Estudos sobre } \\
\text { Educação Física e } \\
\text { Esportes na área } \\
\text { Metropolitana de } \\
\text { São Paulo". }\end{array}$ \\
\hline
\end{tabular}




\begin{tabular}{|c|c|c|c|c|c|}
\hline $\begin{array}{l}08 \text { de } \\
\text { outubro } \\
\text { de } 1971\end{array}$ & $\begin{array}{l}\text { Assembleia } \\
\text { Legislativa } \\
\text { de São } \\
\text { Paulo } \\
\end{array}$ & $\begin{array}{l}\text { Pronunciamen } \\
\text { to }\end{array}$ & Homenagem & & $\begin{array}{l}\text { Voto de louvor ao } \\
\text { Clube Monte } \\
\text { Líbano pela } \\
\text { realização do } \\
\text { Festival das Artes } \\
\text { Inter Clubes. }\end{array}$ \\
\hline $\begin{array}{l}13 \text { de } \\
\text { outubro } \\
\text { de } 1971\end{array}$ & $\begin{array}{l}\text { Assembleia } \\
\text { Legislativa } \\
\text { de São } \\
\text { Paulo } \\
\end{array}$ & Requerimento & Homenagem & 593 & $\begin{array}{l}\text { Congratulações a } \\
\text { Gazeta Esportiva } \\
\text { pelos seu } 24^{\circ} \text { ano } \\
\text { de fundação. }\end{array}$ \\
\hline $\begin{array}{l}18 \text { de } \\
\text { outubro } \\
\text { de } 1971\end{array}$ & $\begin{array}{l}\text { Assembleia } \\
\text { Legislativa } \\
\text { de São } \\
\text { Paulo } \\
\end{array}$ & Requerimento & Homenagem & 593 & $\begin{array}{l}\text { Congratulações a } \\
\text { Gazeta Esportiva } \\
\text { pelos seu } 24^{\circ} \text { ano } \\
\text { de fundação. }\end{array}$ \\
\hline $\begin{array}{l}20 \text { de } \\
\text { outubro } \\
\text { de } 1971\end{array}$ & $\begin{array}{l}\text { Assembleia } \\
\text { Legislativa } \\
\text { de São } \\
\text { Paulo } \\
\end{array}$ & $\begin{array}{l}\text { Pronunciamen } \\
\text { to }\end{array}$ & Discussão & & $\begin{array}{l}\text { Deputado Benedito } \\
\text { Matarazzo fala da } \\
\text { campanha entre } \\
\text { todos os } \\
\text { deputados para } \\
\text { que não se leiloe o } \\
\text { Esporte Clube São } \\
\text { José dos Campos. }\end{array}$ \\
\hline $\begin{array}{l}26 \text { de } \\
\text { outubro } \\
\text { de } 1971\end{array}$ & $\begin{array}{l}\text { Governo do } \\
\text { Estado de } \\
\text { São Paulo }\end{array}$ & Ato Executivo & Publicidade & & $\begin{array}{l}\text { Durante o } \\
\text { encerramento do III } \\
\text { Campeonato } \\
\text { Intersindical de } \\
\text { Futebol, Laudo } \\
\text { Natel anuncia a } \\
\text { construção de uma } \\
\text { praça de esportes, } \\
\text { munida de estádio } \\
\text { de futebol, } \\
\text { destinada a prática } \\
\text { de esportes e } \\
\text { recreação dos } \\
\text { trabalhadores na } \\
\text { chácara Marengo, } \\
\text { e chama líderes } \\
\text { sindicais para se } \\
\text { empenharem no } \\
\text { empreendimento. } \\
\text { Fala sobre } \\
\text { recreação do } \\
\text { trabalhador. }\end{array}$ \\
\hline $\begin{array}{l}27 \text { de } \\
\text { outubro } \\
\text { de } 1971\end{array}$ & $\begin{array}{l}\text { Câmara } \\
\text { Municipal de } \\
\text { São Paulo } \\
\end{array}$ & $\begin{array}{l}\text { Pronunciamen } \\
\text { to }\end{array}$ & Discussão & & $\begin{array}{l}\text { Vereador Naylo de } \\
\text { Oliveira fala da } \\
\text { impossibilidade de } \\
\text { o Corinthians botar } \\
\text { em prática projeto } \\
\text { de construção de } \\
\text { estádio, devido ao } \\
\text { alargamento da } \\
\text { marginal, e sugere } \\
\text { que o Pacaembu } \\
\text { passe a ser o seu } \\
\text { estádio de "mando } \\
\text { de Jogo" até que } \\
\text { se construa o seu } \\
\text { próprio, visto que a } \\
\text { prefeitura }\end{array}$ \\
\hline
\end{tabular}




\begin{tabular}{|c|c|c|c|c|c|}
\hline & & & & & $\begin{array}{l}\text { atrapalhou o } \\
\text { projeto. Vereador } \\
\text { Marcos Melega } \\
\text { alega que se o } \\
\text { Corinthians } \\
\text { quisesse que seus } \\
\text { torcedores o } \\
\text { vissem permitiria o } \\
\text { televisionamento } \\
\text { das partidas. }\end{array}$ \\
\hline $\begin{array}{l}27 \text { de } \\
\text { outubro } \\
\text { de } 1971 \\
\end{array}$ & $\begin{array}{l}\text { Câmara } \\
\text { Municipal de } \\
\text { São Paulo } \\
\end{array}$ & $\begin{array}{l}\text { Pronunciamen } \\
\text { to }\end{array}$ & Discussão & & $\begin{array}{l}\text { Discursão sobre } \\
\text { emprego dos } \\
\text { recursos da Loteria } \\
\text { Esportiva. }\end{array}$ \\
\hline $\begin{array}{l}28 \text { de } \\
\text { outubro } \\
\text { de } 1971\end{array}$ & $\begin{array}{l}\text { Assembleia } \\
\text { Legislativa } \\
\text { de São } \\
\text { Paulo } \\
\end{array}$ & $\begin{array}{l}\text { Pronunciamen } \\
\text { to }\end{array}$ & Discussão & & $\begin{array}{l}\text { Deputado Benedito } \\
\text { Matarazzo } \\
\text { agradece o apoio } \\
\text { da casa e } \\
\text { comunica que o } \\
\text { leilão do Esporte } \\
\text { Clube São José foi } \\
\text { evitado por liminar } \\
\text { na justiça. }\end{array}$ \\
\hline $\begin{array}{l}28 \text { de } \\
\text { outubro } \\
\text { de } 1971\end{array}$ & $\begin{array}{l}\text { Governo do } \\
\text { Estado de } \\
\text { São Paulo }\end{array}$ & Ato Executivo & Publicidade & convênio & $\begin{array}{l}\text { Convênio com a } \\
\text { prefeitura de São } \\
\text { Caetano do Sul } \\
\text { para construção de } \\
2 \text { equipamentos } \\
\text { escolares, munidos } \\
\text { de quadras } \\
\text { cobertas. }\end{array}$ \\
\hline $\begin{array}{l}29 \text { de } \\
\text { outubro } \\
\text { de } 1971\end{array}$ & $\begin{array}{l}\text { Câmara } \\
\text { Municipal de } \\
\text { São Paulo } \\
\end{array}$ & $\begin{array}{l}\text { Pronunciamen } \\
\text { to }\end{array}$ & Discussão & & $\begin{array}{l}\text { discussão sobre } \\
\text { emprego dos } \\
\text { recursos da Loteria } \\
\text { Esportiva. }\end{array}$ \\
\hline $\begin{array}{l}02 \text { de } \\
\text { novembr } \\
\text { o de } \\
1971\end{array}$ & $\begin{array}{l}\text { Câmara } \\
\text { Municipal de } \\
\text { São Paulo }\end{array}$ & $\begin{array}{l}\text { Pronunciamen } \\
\text { to }\end{array}$ & Discussão & & $\begin{array}{l}\text { Vereador Naylo de } \\
\text { Oliveira fala da } \\
\text { repercussão na } \\
\text { imprensa da sua } \\
\text { sugestão sobre o } \\
\text { Pacaembu passar } \\
\text { a ser o estádio de } \\
\text { "mando de Jogo" } \\
\text { do Corinthians até } \\
\text { que se construa o } \\
\text { seu próprio. Teve } \\
\text { apoio de toda } \\
\text { imprensa, e, } \\
\text { apesar de achar } \\
\text { que o prefeito vai } \\
\text { repudiar o projeto, } \\
\text { espera que este } \\
\text { chegue na mesma } \\
\text { conclusão de que é } \\
\text { preciso ceder após } \\
\text { prosseguir com } \\
\text { estudos sobre o } \\
\text { caso. }\end{array}$ \\
\hline
\end{tabular}




\begin{tabular}{|c|c|c|c|c|c|}
\hline $\begin{array}{l}02 \text { de } \\
\text { novembr } \\
\text { o de } \\
1971\end{array}$ & $\begin{array}{l}\text { Governo do } \\
\text { Estado de } \\
\text { São Paulo }\end{array}$ & Ato Executivo & Publicidade & & $\begin{array}{l}\text { Publicidade sobre } \\
\text { obras na Raia } \\
\text { Olímpica. }\end{array}$ \\
\hline $\begin{array}{l}09 \text { de } \\
\text { novembr } \\
\text { o de } \\
1971 \\
\end{array}$ & $\begin{array}{l}\text { Governo do } \\
\text { Estado de } \\
\text { São Paulo }\end{array}$ & Ato Executivo & Veto Total & msg 168 & $\begin{array}{l}\text { Veto total ao } \\
\text { projeto de lei } 171 \\
\text { que visava } \\
\text { estabelecer os } \\
\text { Jogos } \\
\text { Universitários no } \\
\text { Estado. } \\
\text { Governador } \\
\text { justifica dizendo } \\
\text { que o PL vai contra } \\
\text { diretrizes da União. }\end{array}$ \\
\hline $\begin{array}{l}12 \text { de } \\
\text { novembr } \\
\text { o de } \\
1971 \\
\end{array}$ & $\begin{array}{l}\text { Assembleia } \\
\text { Legislativa } \\
\text { de São } \\
\text { Paulo }\end{array}$ & $\begin{array}{l}\text { Ato } \\
\text { Legislativo }\end{array}$ & Projeto Resolução & 17 & $\begin{array}{l}\text { Institui o Troféu } \\
\text { Horácio Barione, a } \\
\text { ser conferido pela } \\
\text { Alesp a todos os } \\
\text { vencedores do } \\
\text { Jogos Abertos do } \\
\text { Interior. }\end{array}$ \\
\hline $\begin{array}{l}12 \text { de } \\
\text { novembr } \\
\text { o de } \\
1971\end{array}$ & $\begin{array}{l}\text { Governo do } \\
\text { Estado de } \\
\text { São Paulo }\end{array}$ & $\begin{array}{l}\text { Ato } \\
\text { Legislativo }\end{array}$ & Decreto & do dia anterior & $\begin{array}{l}\text { Dispõe sobre a } \\
\text { inclusão das } \\
\text { "Provas } \\
\text { Desportivas" } \\
\text { realizadas pela } \\
\text { Coordenadoria do } \\
\text { Trabalho e } \\
\text { Atividades } \\
\text { Complementares } \\
\text { da Secretaria do } \\
\text { Trabalho e } \\
\text { Administração no } \\
\text { calendário oficial } \\
\text { da cidade. }\end{array}$ \\
\hline $\begin{array}{l}12 \text { de } \\
\text { novembr } \\
\text { o de } \\
1971\end{array}$ & $\begin{array}{l}\text { Governo do } \\
\text { Estado de } \\
\text { São Paulo }\end{array}$ & Ato Executivo & Publicidade & & $\begin{array}{l}\text { Anúncio de aulas } \\
\text { de natação para } \\
\text { crianças no ginásio } \\
\text { do lbirapuera. }\end{array}$ \\
\hline $\begin{array}{l}12 \text { de } \\
\text { novembr } \\
\text { o de } \\
1971\end{array}$ & $\begin{array}{l}\text { Governo do } \\
\text { Estado de } \\
\text { São Paulo }\end{array}$ & Ato Executivo & Publicidade & & $\begin{array}{l}\text { Agradecimento a } \\
\text { mensagem do } \\
\text { governador à } \\
\text { província de } \\
\text { Wakayama - } \\
\text { Japão, pela } \\
\text { realização das } \\
\text { Olimpíadas } \\
\text { esportivas. }\end{array}$ \\
\hline $\begin{array}{l}12 \text { de } \\
\text { novembr } \\
\text { o de } \\
1971\end{array}$ & $\begin{array}{l}\text { Governo do } \\
\text { Estado de } \\
\text { São Paulo }\end{array}$ & Ato Executivo & Publicidade & & $\begin{array}{l}\text { Reunião do Comitê } \\
\text { Olímpico no } \\
\text { Palácio dos } \\
\text { Bandeirantes, a } \\
\text { convite do } \\
\text { governador. }\end{array}$ \\
\hline $\begin{array}{l}17 \text { de } \\
\text { novembr } \\
\text { o de } \\
1971\end{array}$ & $\begin{array}{l}\text { Governo do } \\
\text { Estado de } \\
\text { São Paulo }\end{array}$ & Ato Executivo & Publicidade & DEFE & $\begin{array}{l}\text { Anúncio de } \\
\text { Construção e } \\
\text { Praças Esportivas } \\
\text { no Interior. }\end{array}$ \\
\hline
\end{tabular}




\begin{tabular}{|c|c|c|c|c|c|}
\hline $\begin{array}{l}18 \text { de } \\
\text { novembr } \\
\text { o de } \\
1971\end{array}$ & $\begin{array}{l}\text { Assembleia } \\
\text { Legislativa } \\
\text { de São } \\
\text { Paulo }\end{array}$ & $\begin{array}{l}\text { Pronunciamen } \\
\text { to }\end{array}$ & Discussão & & $\begin{array}{l}\text { Deputado Ary Silva } \\
\text { fala da polêmica } \\
\text { sobre a não } \\
\text { execução do hino } \\
\text { nacional em } \\
\text { campeonato de } \\
\text { basquetebol em } \\
\text { Lima, onde o Brasil } \\
\text { foi representado } \\
\text { pelo clube Sírio. O } \\
\text { clube pediu para } \\
\text { executar o hino e a } \\
\text { solenidade foi } \\
\text { interrompida por } \\
\text { alguns minutos. } \\
\end{array}$ \\
\hline $\begin{array}{l}26 \text { de } \\
\text { novembr } \\
\text { o de } \\
1971\end{array}$ & $\begin{array}{l}\text { Assembleia } \\
\text { Legislativa } \\
\text { de São } \\
\text { Paulo } \\
\end{array}$ & Parecer & $\mathrm{PL}$ & 1123 & \begin{tabular}{|l} 
Parecer sobre o PL \\
$311 / 71$, que \\
dispunha sobre a \\
obrigatoriedade do \\
ensino de Xadrez \\
nos \\
estabelecimentos \\
de ensino públicos \\
e privados do \\
estado. Parecer \\
favorável. \\
\end{tabular} \\
\hline $\begin{array}{l}27 \text { de } \\
\text { novembr } \\
\text { o de } \\
1971\end{array}$ & $\begin{array}{l}\text { Assembleia } \\
\text { Legislativa } \\
\text { de São } \\
\text { Paulo }\end{array}$ & Parecer & PL & & $\begin{array}{l}\text { Parecer contrário } \\
\text { ao projeto de lei } \\
171 \text { que visava } \\
\text { estabelecer os } \\
\text { Jogos } \\
\text { Universitários no } \\
\text { Estado. }\end{array}$ \\
\hline $\begin{array}{l}30 \text { de } \\
\text { novembr } \\
\text { o de } \\
1971\end{array}$ & $\begin{array}{l}\text { Governo do } \\
\text { Estado de } \\
\text { São Paulo }\end{array}$ & Visita & Publicidade & Reunião & $\begin{array}{l}\text { Visita de } \\
\text { parlamentares } \\
\text { federais a } \\
\text { governador e mais } \\
4 \text { deputados. } \\
\text { Deputado Mario } \\
\text { Telles tratou do } \\
\text { esporte e foi } \\
\text { ressaltado o papel } \\
\text { de São Paulo para } \\
\text { o aprimoramento } \\
\text { da legislação no } \\
\text { setor. }\end{array}$ \\
\hline $\begin{array}{l}01 \text { de } \\
\text { dezembr } \\
\text { o de } \\
1971\end{array}$ & $\begin{array}{l}\text { Assembleia } \\
\text { Legislativa } \\
\text { de São } \\
\text { Paulo }\end{array}$ & Requerimento & Homenagem & 827 & $\begin{array}{l}\text { Voto de } \\
\text { congratulações a } \\
\text { Sociedade } \\
\text { Columbófila Tietê, } \\
\text { por sua atuação no } \\
\text { esporte amado } \\
\text { (llegível). }\end{array}$ \\
\hline $\begin{array}{l}04 \text { de } \\
\text { dezembr } \\
\text { o de } \\
1971\end{array}$ & $\begin{array}{l}\text { Assembleia } \\
\text { Legislativa } \\
\text { de São } \\
\text { Paulo }\end{array}$ & CPI & Instrução & Título VI & $\begin{array}{l}\text { Trata do retorno de } \\
\text { recursos da Loteria } \\
\text { Esportiva ao } \\
\text { Mercado de } \\
\text { Capitais. Destina } \\
20 \% \text { a obras } \\
\text { sociais e de }\end{array}$ \\
\hline
\end{tabular}




\begin{tabular}{|c|c|c|c|c|c|}
\hline & & & & & $\begin{array}{l}\text { geração de } \\
\text { emprego - tira do } \\
\text { esporte. }\end{array}$ \\
\hline & & & & & \\
\hline $\begin{array}{l}28 \text { de } \\
\text { dezembr } \\
\text { o de } \\
1972 \\
\end{array}$ & $\begin{array}{l}\text { Governo do } \\
\text { Estado de } \\
\text { São Paulo } \\
\end{array}$ & Ato Executivo & Publicidade & Recursos & $\begin{array}{l}\text { Orçamento do ano } \\
\text { seguinte, } 1972, \\
\text { para a Secretaria } \\
\text { de Cultura, Esporte } \\
\text { e Turismo. }\end{array}$ \\
\hline $\begin{array}{l}04 \text { de } \\
\text { janeiro } \\
\text { de } 1972\end{array}$ & \begin{tabular}{|l} 
Câmara \\
Municipal de \\
São Paulo \\
\end{tabular} & \begin{tabular}{|l} 
Ato \\
Legislativo
\end{tabular} & Homenagem & & $\begin{array}{l}\text { Entrega de Troféus } \\
\text { na Câmara para a } \\
\text { Fundação Casper } \\
\text { Líbero, pela } \\
\text { realização da 47ำ } \\
\text { Corrida de São } \\
\text { Silvestre. }\end{array}$ \\
\hline $\begin{array}{l}13 \text { de } \\
\text { janeiro } \\
\text { de } 1972\end{array}$ & $\begin{array}{l}\text { Governo do } \\
\text { Estado de } \\
\text { São Paulo } \\
\end{array}$ & Ato Executivo & Publicidade & Reunião/DEFE & $\begin{array}{l}\text { Realização de } \\
\text { reuniões no interior } \\
\text { dos técnicos do } \\
\text { DEFE para } \\
\text { implementar plano } \\
\text { de apoio ao } \\
\text { esporte amador no } \\
\text { estado. } \\
\end{array}$ \\
\hline $\begin{array}{l}22 \text { de } \\
\text { fevereiro } \\
\text { de } 1972\end{array}$ & $\begin{array}{l}\text { Câmara } \\
\text { Municipal de } \\
\text { São Paulo }\end{array}$ & Requerimento & Homenagem & P9172 & \begin{tabular}{|l} 
Voto de júbilo pela \\
reeleição do \\
esportista Oswaldo \\
Caviglia no cargo \\
de Presidente da \\
Federação Paulista \\
de Basquetebol
\end{tabular} \\
\hline $\begin{array}{l}22 \text { de } \\
\text { fevereiro } \\
\text { de } 1972\end{array}$ & \begin{tabular}{|l} 
Câmara \\
Municipal de \\
São Paulo \\
\end{tabular} & $\begin{array}{l}\text { Pronunciamen } \\
\text { to }\end{array}$ & Discussão & & $\begin{array}{l}\text { Discussão sobre a } \\
\text { matéria do Diário } \\
\text { popular sobre as } \\
\text { Olimpíadas de } \\
\text { Inverno que } \\
\text { ocorreram em } \\
\text { Sapporo, no } \\
\text { Japão. } \\
\end{array}$ \\
\hline $\begin{array}{l}29 \text { de } \\
\text { fevereiro } \\
\text { de } 1972 \\
\end{array}$ & $\begin{array}{l}\text { Câmara } \\
\text { Municipal de } \\
\text { São Paulo } \\
\end{array}$ & Requerimento & Homenagem & 5272 & $\begin{array}{l}\text { Voto de júbilo a } \\
\text { Prefeitura de São } \\
\text { Paulo pera } \\
\text { realização da VII } \\
\text { Olimpíada Infantil } \\
\text { na cidade. } \\
\end{array}$ \\
\hline $\begin{array}{l}05 \text { de } \\
\text { abril de } \\
1972\end{array}$ & $\begin{array}{l}\text { Governo do } \\
\text { Estado de } \\
\text { São Paulo }\end{array}$ & Ato Executivo & Publicidade & $\begin{array}{l}\text { Prestação de } \\
\text { Contas }\end{array}$ & $\begin{array}{l}\text { Prestação de } \\
\text { Contas do governo } \\
\text { do ano anterior - } \\
\text { DEFE. }\end{array}$ \\
\hline $\begin{array}{l}05 \text { de } \\
\text { abril de } \\
1972 \\
\end{array}$ & \begin{tabular}{|l|} 
Governo do \\
Estado de \\
São Paulo \\
\end{tabular} & Ato Executivo & Ao Legislativo & $\begin{array}{l}\text { Prestação de } \\
\text { Contas }\end{array}$ & $\begin{array}{l}\text { Mensagem a Alesp } \\
\text { sobre as ações do } \\
\text { governo. }\end{array}$ \\
\hline $\begin{array}{l}12 \text { de } \\
\text { abril de } \\
1972\end{array}$ & $\begin{array}{l}\text { Governo do } \\
\text { Estado de } \\
\text { São Paulo } \\
\end{array}$ & Projeto de Lei & Ao Legislativo & 1172 & $\begin{array}{l}\text { Visa autorizar a } \\
\text { Fazenda do Estado } \\
\text { a contratar a } \\
\text { prefeitura de } \\
\text { Queluz para } \\
\text { concessão de ilha } \\
\text { situada no Rio } \\
\end{array}$ \\
\hline
\end{tabular}




\begin{tabular}{|c|c|c|c|c|c|}
\hline & & & & & \begin{tabular}{|l} 
Pariatã para a \\
construção de \\
praça de esportes \\
e parque \\
zoológico.
\end{tabular} \\
\hline $\begin{array}{l}12 \text { de } \\
\text { abril de } \\
1972\end{array}$ & $\begin{array}{l}\text { Assembleia } \\
\text { Legislativa } \\
\text { de São } \\
\text { Paulo } \\
\end{array}$ & $\begin{array}{l}\text { Pronunciamen } \\
\text { to }\end{array}$ & Ao executivo & & \begin{tabular}{|l} 
Deputado Hatiro \\
Shimomoto manda \\
ofício ao \\
governador \\
pedindo a criação \\
do Vale do Esporte \\
e Cultura nas \\
Margens do Tietê, \\
conforme apelo \\
feito em agosto de \\
1971. \\
\end{tabular} \\
\hline $\begin{array}{l}18 \text { de } \\
\text { abril de } \\
1972\end{array}$ & $\begin{array}{l}\text { Governo do } \\
\text { Estado de } \\
\text { São Paulo }\end{array}$ & Ato Executivo & Publicidade & & $\begin{array}{l}\text { Inauguração em } \\
\text { Catanduva de } \\
\text { Ginásio Estadual, } \\
\text { munido de praça } \\
\text { de esportes. }\end{array}$ \\
\hline $\begin{array}{l}19 \text { de } \\
\text { abril de } \\
1972\end{array}$ & $\begin{array}{l}\text { Assembleia } \\
\text { Legislativa } \\
\text { de São } \\
\text { Paulo }\end{array}$ & Requerimento & Homenagem & 62 & $\begin{array}{l}\text { Voto de júbilo ao } \\
\text { Sr. Paulo Machado } \\
\text { de Carvalho, } \\
\text { Secretário de } \\
\text { Esportes do } \\
\text { Município de São } \\
\text { Paulo, pelo } \\
\text { recebimento da } \\
\text { "Medalha Rio } \\
\text { Branco". }\end{array}$ \\
\hline $\begin{array}{l}28 \text { de } \\
\text { abril de } \\
1972\end{array}$ & $\begin{array}{l}\text { Assembleia } \\
\text { Legislativa } \\
\text { de São } \\
\text { Paulo } \\
\end{array}$ & Convite & Ao Legislativo & Sociedade Civil & $\begin{array}{l}\text { Convite a Alesp da } \\
\text { Associação Atlética } \\
\text { Caramuru para } \\
\text { participação na } \\
\text { comemoração do } \\
\text { 19o- aniversário do } \\
\text { clube. } \\
\end{array}$ \\
\hline $\begin{array}{l}29 \text { de } \\
\text { abril de } \\
1972\end{array}$ & $\begin{array}{l}\text { Governo do } \\
\text { Estado de } \\
\text { São Paulo }\end{array}$ & Ato Executivo & Publicidade & Licitação & \begin{tabular}{|l} 
Abertura de \\
concorrência \\
pública para \\
aquisição de \\
troféus e \\
medalhas. \\
\end{tabular} \\
\hline $\begin{array}{l}03 \text { de } \\
\text { maio de } \\
1972\end{array}$ & $\begin{array}{l}\text { Governo do } \\
\text { Estado de } \\
\text { São Paulo }\end{array}$ & Ato Executivo & Publicidade & Licitação & $\begin{array}{l}\text { Abertura de } \\
\text { concorrência } \\
\text { pública para } \\
\text { aquisição de } \\
\text { troféus e } \\
\text { medalhas. }\end{array}$ \\
\hline $\begin{array}{l}10 \text { de } \\
\text { maio de } \\
1972\end{array}$ & $\begin{array}{l}\text { Governo do } \\
\text { Estado de } \\
\text { São Paulo }\end{array}$ & Ato Executivo & Portaria & 372 & $\begin{array}{l}\text { Dispõe sobre } \\
\text { regras dos Jogos } \\
\text { Abertos do Interior } \\
\text { e preparação } \\
\text { técnica dos atletas. }\end{array}$ \\
\hline $\begin{array}{l}12 \text { de } \\
\text { maio de } \\
1972\end{array}$ & $\begin{array}{l}\text { Assembleia } \\
\text { Legislativa } \\
\text { de São } \\
\text { Paulo }\end{array}$ & Parecer & & & \begin{tabular}{|l|} 
Comissão de \\
constituição de \\
justiça sobre o \\
Fundo de Melhoria \\
das Estâncias.
\end{tabular} \\
\hline
\end{tabular}




\begin{tabular}{|c|c|c|c|c|c|}
\hline $\begin{array}{l}17 \text { de } \\
\text { maio de } \\
1972\end{array}$ & \begin{tabular}{|l} 
Assembleia \\
Legislativa \\
de São \\
Paulo \\
\end{tabular} & Requerimento & Homenagem & 147 & \begin{tabular}{|l|} 
Congratulação a \\
(?) Bastos pela \\
inauguração e \\
campo de Golf. \\
\end{tabular} \\
\hline $\begin{array}{l}17 \text { de } \\
\text { maio de } \\
1972\end{array}$ & $\begin{array}{l}\text { Assembleia } \\
\text { Legislativa } \\
\text { de São } \\
\text { Paulo } \\
\end{array}$ & Ato Executivo & Publicidade & $\begin{array}{l}\text { Liberação de } \\
\text { Recursos }\end{array}$ & $\begin{array}{l}\text { Governo autoriza } \\
\text { novas obras } \\
\text { escolares na } \\
\text { capital e no } \\
\text { interior, prevendo a } \\
\text { construção de } \\
\text { equipamentos } \\
\text { esportivos nos } \\
\text { estabelecimentos } \\
\text { de ensino. }\end{array}$ \\
\hline $\begin{array}{l}17 \text { de } \\
\text { maio de } \\
1972\end{array}$ & $\begin{array}{l}\text { Assembleia } \\
\text { Legislativa } \\
\text { de São } \\
\text { Paulo } \\
\end{array}$ & Parecer & Moção & 13 & $\begin{array}{l}\text { Parecer } 182 \text { sobre } \\
\text { a Moção } 13 \text { do } \\
\text { deputado Nesralla } \\
\text { Rubez que apela } \\
\text { ao Sr. Presidente } \\
\text { da República que } \\
\text { destine parte do } \\
\text { recurso da Loteria } \\
\text { Esportiva as } \\
\text { cidades paulistas } \\
\text { sedes dos Jogos } \\
\text { Abertos do Interior } \\
\text { e Jogos Regionais. } \\
\text { Parecer favorável, } \\
\text { acolhimento da } \\
\text { moção. } \\
\end{array}$ \\
\hline $\begin{array}{l}20 \text { de } \\
\text { maio de } \\
1972\end{array}$ & $\begin{array}{l}\text { Assembleia } \\
\text { Legislativa } \\
\text { de São } \\
\text { Paulo } \\
\end{array}$ & $\begin{array}{l}\text { Pronunciamen } \\
\text { to }\end{array}$ & Homenagem & & $\begin{array}{l}\text { Deputado João do } \\
\text { Prado fala sobre a } \\
\text { notícia da decisão } \\
\text { do XV de } \\
\text { novembro de Jaú } \\
\text { de construir } \\
\text { estádio, superando } \\
\text { a construção } \\
\text { deteriorada de } \\
\text { madeira, feita a } 18 \\
\text { anos, para } \\
\text { ingresso na } \\
\text { primeira divisão. }\end{array}$ \\
\hline $\begin{array}{l}23 \text { de } \\
\text { maio de } \\
1972\end{array}$ & $\begin{array}{l}\text { Assembleia } \\
\text { Legislativa } \\
\text { de São } \\
\text { Paulo } \\
\end{array}$ & Requerimento & Homenagem & 164 & \begin{tabular}{|l} 
Voto de jubilo a \\
Confederação \\
Brasileira de \\
Xadrez pela \\
realização, no \\
espaço do Club \\
Atlético Paulistano, \\
do VIII Zonal Sul- \\
americano de \\
Xadrez Masculino. \\
Autoria do \\
Deputado Wadih \\
Helu. \\
\end{tabular} \\
\hline
\end{tabular}




\begin{tabular}{|c|c|c|c|c|c|}
\hline \begin{tabular}{|l}
23 de \\
maio de \\
1972 \\
\end{tabular} & \begin{tabular}{|l} 
Assembleia \\
Legislativa \\
de São \\
Paulo \\
\end{tabular} & $\begin{array}{l}\text { Pronunciamen } \\
\text { to }\end{array}$ & Ao executivo & & \begin{tabular}{|l} 
Deputado Solon \\
Borges propões ao \\
governo a \\
realização de \\
convênios com \\
prefeituras da \\
capital e do interior \\
para que procedam \\
com a construção \\
de clubes para \\
jovens, visando a \\
prática esportiva, \\
sociabilização e \\
cultura. \\
\end{tabular} \\
\hline \begin{tabular}{|l}
27 de \\
maio de \\
1972 \\
\end{tabular} & \begin{tabular}{|l} 
Governo do \\
Estado de \\
São Paulo \\
\end{tabular} & Ato Executivo & Publicidade & & \begin{tabular}{|l} 
Liberação de \\
recursos para a \\
secretaria de \\
Cultura, Esportes e \\
Turismo, entre \\
outros. \\
\end{tabular} \\
\hline $\begin{array}{l}30 \text { de } \\
\text { maio de } \\
1972\end{array}$ & $\begin{array}{l}\text { Câmara } \\
\text { Municipal de } \\
\text { São Paulo }\end{array}$ & $\begin{array}{l}\text { Pronunciamen } \\
\text { to }\end{array}$ & Ao executivo & & $\begin{array}{l}\text { Vereador Mario } \\
\text { Osassa fala que a } \\
\text { prefeitura tem feito } \\
\text { um bom trabalho } \\
\text { liberando a título } \\
\text { precário o uso de } \\
\text { terrenos a times de } \\
\text { várzea, no entanto } \\
\text { a burocracia tem } \\
\text { complicado o } \\
\text { acesso dos times, } \\
\text { visto que } \\
\text { demandam filiação } \\
\text { na federação, que } \\
\text { Ihes cobra o valor } \\
\text { de CR } \$ 100, \text { mais } \\
\text { mensalidade de } \\
\text { cinquenta cruzeiros } \\
\text { ou mais. }\end{array}$ \\
\hline $\begin{array}{l}30 \text { de } \\
\text { maio de } \\
1972\end{array}$ & $\begin{array}{l}\text { Assembleia } \\
\text { Legislativa } \\
\text { de São } \\
\text { Paulo }\end{array}$ & Requerimento & Homenagem & 175 & \begin{tabular}{|l|} 
Voto de \\
congratulação a \\
Campinas pelo 54ㅇ \\
do Clube \\
Campineiro de \\
Regatas e \\
Natação. \\
\end{tabular} \\
\hline \begin{tabular}{|l}
$\begin{array}{l}06 \text { de } \\
\text { junho de } \\
1972\end{array}$ \\
\end{tabular} & $\begin{array}{l}\text { Governo do } \\
\text { Estado de } \\
\text { São Paulo }\end{array}$ & Homenagem & Publicidade & 175 & $\begin{array}{l}\text { Homenagem dos } \\
\text { trabalhadores de } \\
\text { São Paulo ao } \\
\text { Governador do } \\
\text { Estado e ao } \\
\text { Presidente da } \\
\text { República, em } \\
\text { especial pela } \\
\text { construção do } \\
\text { CERET - Centro } \\
\text { Educativo, } \\
\text { Recreativo e } \\
\text { Esportivo dos } \\
\text { Trabalhadores. }\end{array}$ \\
\hline
\end{tabular}




\begin{tabular}{|c|c|c|c|c|c|}
\hline $\begin{array}{l}07 \text { de } \\
\text { junho de } \\
1972\end{array}$ & $\begin{array}{l}\text { Assembleia } \\
\text { Legislativa } \\
\text { de São } \\
\text { Paulo }\end{array}$ & $\begin{array}{l}\text { Pronunciamen } \\
\text { to }\end{array}$ & Homenagem & & \begin{tabular}{|l} 
Deputado Wadih \\
Helu fala sobre as \\
vésperas da \\
Olimpíada e \\
agradece o \\
trabalho feito pelo \\
major Sylvio \\
Magalhães Padilha \\
(Diretor do DEFE), \\
ao lado de seu \\
filho, Pedro \\
Magalhães Padilha \\
(Secretária de \\
Cultura, Esporte e \\
Turismo).
\end{tabular} \\
\hline $\begin{array}{l}09 \text { de } \\
\text { junho de } \\
1972\end{array}$ & $\begin{array}{l}\text { Assembleia } \\
\text { Legislativa } \\
\text { de São } \\
\text { Paulo }\end{array}$ & $\begin{array}{l}\text { Pronunciamen } \\
\text { to }\end{array}$ & Homenagem & & $\begin{array}{l}\text { Deputado Ruy } \\
\text { Codo faz } \\
\text { homenagem à } \\
\text { família Fittipaldi } \\
\text { pela atuação no } \\
\text { esporte. } \\
\end{array}$ \\
\hline $\begin{array}{l}13 \text { de } \\
\text { junho de } \\
1972\end{array}$ & $\begin{array}{l}\text { Câmara } \\
\text { Municipal de } \\
\text { São Paulo }\end{array}$ & $\begin{array}{l}\text { Pronunciamen } \\
\text { to }\end{array}$ & Discussão & & $\begin{array}{l}\text { Vereador Samir } \\
\text { Achoa fala das } \\
\text { denúncias de } \\
\text { irregularidades } \\
\text { sobre o } \\
\text { Corinthians, diz } \\
\text { que após as } \\
\text { denúncias na } \\
\text { imprensa sobre } \\
\text { títulos protestados } \\
\text { os torcedores } \\
\text { merecem uma } \\
\text { resposta, porém } \\
\text { sai em defesa do } \\
\text { clube. }\end{array}$ \\
\hline $\begin{array}{l}14 \text { de } \\
\text { junho de } \\
1972\end{array}$ & $\begin{array}{l}\text { Assembleia } \\
\text { Legislativa } \\
\text { de São } \\
\text { Paulo } \\
\end{array}$ & $\begin{array}{l}\text { Pronunciamen } \\
\text { to }\end{array}$ & Discussão & & $\begin{array}{l}\text { Deputado Ricardo } \\
\text { Izar fala das } \\
\text { denúncias de } \\
\text { irregularidades } \\
\text { sobre o } \\
\text { Corinthians, diz } \\
\text { que após as } \\
\text { denúncias na } \\
\text { imprensa sobre } \\
\text { títulos protestados } \\
\text { os torcedores } \\
\text { merecem uma } \\
\text { resposta, porém } \\
\text { sai em defesa do } \\
\text { clube. }\end{array}$ \\
\hline $\begin{array}{l}16 \text { de } \\
\text { junho de } \\
1972\end{array}$ & $\begin{array}{l}\text { Assembleia } \\
\text { Legislativa } \\
\text { de São } \\
\text { Paulo } \\
\end{array}$ & Projeto de Lei & Apresentação & $118 / 72$ & $\begin{array}{l}\text { Projeto de Lei que } \\
\text { prevê a criação do } \\
\text { "dia do Salonista", } \\
\text { dia } 14 \text { de junho, } \\
\text { dia em que foi } \\
\text { fundada a } \\
\text { Federação Paulista } \\
\text { de Futebol de }\end{array}$ \\
\hline
\end{tabular}




\begin{tabular}{|c|c|c|c|c|c|}
\hline & & & & & $\begin{array}{l}\text { Salão. Autoria de } \\
\text { José Maria Marin. }\end{array}$ \\
\hline \begin{tabular}{|l|l|}
17 de \\
junho de \\
1972 \\
\end{tabular} & $\begin{array}{l}\text { Governo do } \\
\text { Estado de } \\
\text { São Paulo }\end{array}$ & Ato Executivo & Publicidade & & $\begin{array}{l}\text { Anúncio do início } \\
\text { das obras do } \\
\text { CERET. }\end{array}$ \\
\hline \begin{tabular}{|l}
20 de \\
junho de \\
1972 \\
\end{tabular} & $\begin{array}{l}\text { Assembleia } \\
\text { Legislativa } \\
\text { de São } \\
\text { Paulo } \\
\end{array}$ & Requerimento & Voto de Pesar & 225 & \begin{tabular}{|l|} 
Deputado Wadih \\
Helu solicita voto \\
de pesar pelo \\
falecimento de Luiz \\
Afonso Perez - \\
Santos. \\
\end{tabular} \\
\hline $\begin{array}{l}20 \text { de } \\
\text { junho de } \\
1972\end{array}$ & $\begin{array}{l}\text { Governo do } \\
\text { Estado de } \\
\text { São Paulo }\end{array}$ & Ato Executivo & Publicidade & & $\begin{array}{l}\text { Secretário Pedro } \\
\text { Padilha e } \\
\text { governador Laudo } \\
\text { Natel encaminham } \\
\text { a requisição d } 22 \\
\text { prefeitos para a } \\
\text { liberação de } \\
\text { verbas para } \\
\text { ampliação e } \\
\text { reforma de centros } \\
\text { esportivos em } \\
\text { diversas cidades } \\
\text { do interior. }\end{array}$ \\
\hline $\begin{array}{l}23 \text { de } \\
\text { junho de } \\
1972\end{array}$ & $\begin{array}{l}\text { Assembleia } \\
\text { Legislativa } \\
\text { de São } \\
\text { Paulo }\end{array}$ & $\begin{array}{l}\text { Pronunciamen } \\
\text { to }\end{array}$ & Discussão & & $\begin{array}{l}\text { Deputado Jayro } \\
\text { Maltoni crítica a } \\
\text { ação da Federação } \\
\text { Paulista de Futebol } \\
\text { de suspendei a Lei } \\
\text { do Acesso aos } \\
\text { clubes da primeira } \\
\text { divisão. }\end{array}$ \\
\hline $\begin{array}{l}08 \text { de } \\
\text { agosto } \\
\text { de } 1972\end{array}$ & $\begin{array}{l}\text { Assembleia } \\
\text { Legislativa } \\
\text { de São } \\
\text { Paulo } \\
\end{array}$ & $\begin{array}{l}\text { Pronunciamen } \\
\text { to }\end{array}$ & Discussão & & $\begin{array}{l}\text { Deputado Hatiro } \\
\text { Shimomoto fala da } \\
\text { solicitação da } \\
\text { entidade } \\
\text { Associação } \\
\text { Paroquial de } \\
\text { Capivari de se } \\
\text { pedir ao } \\
\text { governador que se } \\
\text { termine as obras } \\
\text { no ginásio de } \\
\text { esporte no Instituto } \\
\text { de Educação local. }\end{array}$ \\
\hline $\begin{array}{l}15 \text { de } \\
\text { agosto } \\
\text { de } 1972\end{array}$ & $\begin{array}{l}\text { Governo do } \\
\text { Estado de } \\
\text { São Paulo }\end{array}$ & Ato Executivo & Publicidade & Inauguração & $\begin{array}{l}\text { Inauguração do } \\
\text { Estádio Castelo } \\
\text { Branco em São } \\
\text { Bernardo do } \\
\text { Campo. }\end{array}$ \\
\hline $\begin{array}{l}19 \text { de } \\
\text { agosto } \\
\text { de } 1972\end{array}$ & $\begin{array}{l}\text { Governo do } \\
\text { Estado de } \\
\text { São Paulo }\end{array}$ & Ato Executivo & Publicidade & Contrato & $\begin{array}{l}\text { Contratação das } \\
\text { Federações } \\
\text { Paulistas e } \\
\text { Hipismo e } \\
\text { Atletismo para } \\
\text { promoção de } \\
\text { evento esportivo. }\end{array}$ \\
\hline
\end{tabular}




\begin{tabular}{|c|c|c|c|c|c|}
\hline $\begin{array}{l}25 \text { de } \\
\text { agosto } \\
\text { de } 1972\end{array}$ & $\begin{array}{l}\text { Assembleia } \\
\text { Legislativa } \\
\text { de São } \\
\text { Paulo }\end{array}$ & $\begin{array}{l}\text { Pronunciamen } \\
\text { to }\end{array}$ & Discussão & & $\begin{array}{l}\text { Deputado Hatiro } \\
\text { Shimomoto volta a } \\
\text { falar da criação do } \\
\text { Vale do Esporte e } \\
\text { Cultura. }\end{array}$ \\
\hline $\begin{array}{l}25 \text { de } \\
\text { agosto } \\
\text { de } 1972\end{array}$ & $\begin{array}{l}\text { Assembleia } \\
\text { Legislativa } \\
\text { de São } \\
\text { Paulo } \\
\end{array}$ & $\begin{array}{l}\text { Pronunciamen } \\
\text { to }\end{array}$ & Discussão & & $\begin{array}{l}\text { Deputado Ary Silva } \\
\text { discursa sobre o } \\
\text { esporte, } \\
\text { olimpíadas e } \\
\text { Loteria Esportiva. }\end{array}$ \\
\hline $\begin{array}{l}26 \text { de } \\
\text { agosto } \\
\text { de } 1972\end{array}$ & $\begin{array}{l}\text { Assembleia } \\
\text { Legislativa } \\
\text { de São } \\
\text { Paulo } \\
\end{array}$ & Requerimento & Homenagem & 361 & \begin{tabular}{|l} 
Congratulações ao \\
Palmeiras pelo seu \\
$58^{\circ}$ aniversário. \\
Deputado José \\
Filho Castelhano.
\end{tabular} \\
\hline $\begin{array}{l}29 \text { de } \\
\text { agosto } \\
\text { de } 1972\end{array}$ & $\begin{array}{l}\text { Assembleia } \\
\text { Legislativa } \\
\text { de São } \\
\text { Paulo }\end{array}$ & $\begin{array}{l}\text { Pronunciamen } \\
\text { to }\end{array}$ & Discussão & & $\begin{array}{l}\text { Deputado Jacob } \\
\text { Salvador Zveiril } \\
\text { fala da questão do } \\
\text { racismo no } \\
\text { esporte, usando o } \\
\text { caso da Rodésia } \\
\text { na Olimpíada de } \\
\text { Munique. }\end{array}$ \\
\hline $\begin{array}{l}31 \text { de } \\
\text { agosto } \\
\text { de } 1972\end{array}$ & $\begin{array}{l}\text { Governo do } \\
\text { Estado de } \\
\text { São Paulo }\end{array}$ & Ato Executivo & Publicidade & & \begin{tabular}{|l} 
Em visita aos \\
municípios de \\
Leme, Araras e \\
Conchal, o \\
Governador Laudo \\
Natel anuncia o \\
programa PRÓ- \\
ESPORTE, que \\
terá como diretriz \\
munir todos os \\
municípios do \\
estado com praças \\
de esporte. \\
\end{tabular} \\
\hline $\begin{array}{l}02 \text { de } \\
\text { setembr } \\
\text { o de } \\
1972\end{array}$ & $\begin{array}{l}\text { Governo do } \\
\text { Estado de } \\
\text { São Paulo }\end{array}$ & Ato Executivo & & DEFE & $\begin{array}{l}\text { Estágio de } \\
\text { aperfeiçoamento } \\
\text { no exterior para } \\
\text { professores do } \\
\text { DEFE. } \\
\end{array}$ \\
\hline $\begin{array}{l}13 \text { de } \\
\text { setembr } \\
\text { o de } \\
1972 \\
\end{array}$ & $\begin{array}{l}\text { Assembleia } \\
\text { Legislativa } \\
\text { de São } \\
\text { Paulo } \\
\end{array}$ & $\begin{array}{l}\text { Pronunciamen } \\
\text { to }\end{array}$ & Discussão & & $\begin{array}{l}\text { Falas na Alesp } \\
\text { sobre o ocorrido } \\
\text { nas Olimpíadas de } \\
\text { Munique. Também } \\
\text { discutem sobre o } \\
\text { papel dos esportes } \\
\text { e como o futebol } \\
\text { acaba "abafando" } \\
\text { as demais } \\
\text { modalidades. }\end{array}$ \\
\hline $\begin{array}{l}13 \text { de } \\
\text { setembr } \\
\text { o de } \\
1972 \\
\end{array}$ & $\begin{array}{l}\text { Assembleia } \\
\text { Legislativa } \\
\text { de São } \\
\text { Paulo } \\
\end{array}$ & Moção & & $S / n$ & $\begin{array}{l}\text { Moção para que o } \\
\text { Autódromo de } \\
\text { Interlagos passe a } \\
\text { se chamar } \\
\text { Autódromo } \\
\text { Fittipaldi. } \\
\end{array}$ \\
\hline
\end{tabular}




\begin{tabular}{|c|c|c|c|c|c|}
\hline \begin{tabular}{|l}
14 de \\
setembr \\
o de \\
1972 \\
\end{tabular} & $\begin{array}{l}\text { Governo do } \\
\text { Estado de } \\
\text { São Paulo } \\
\end{array}$ & Ato Executivo & Publicidade & & \begin{tabular}{|l} 
Em fala do \\
Governador sobre \\
a Interiorização \\
que passou a ser \\
exigência para a \\
segurança \\
nacional, ele diz \\
que a Secretaria \\
de Cultura, Esporte \\
e Turismo concluiu \\
estudo sobre como \\
incrementar a \\
prática do esporte \\
entre a população \\
de jovens, entre 17 \\
e 25 anos, de \\
quase todos os \\
municípios \\
paulistas, \\
buscando alcançar \\
parâmetros do \\
Comitê Olímpico \\
Internacional. \\
\end{tabular} \\
\hline $\begin{array}{l}21 \text { de } \\
\text { setembr } \\
\text { o de } \\
1972 \\
\end{array}$ & \begin{tabular}{|l} 
Assembleia \\
Legislativa \\
de São \\
Paulo \\
\end{tabular} & Indicação & Ao executivo & 895 & $\begin{array}{l}\text { Deputado Leonel } \\
\text { Júlio indica ao } \\
\text { executivo que a } \\
\text { reforma do prédio } \\
\text { do } 2^{\circ} \text { Ginásio } \\
\text { Estadual de Artur } \\
\text { Alvim, além de } \\
\text { muni-lo com } \\
\text { quadra de } \\
\text { esportes. }\end{array}$ \\
\hline $\begin{array}{l}22 \text { de } \\
\text { setembr } \\
\text { o de } \\
1972 \\
\end{array}$ & $\begin{array}{l}\text { Governo do } \\
\text { Estado de } \\
\text { São Paulo }\end{array}$ & Ato Executivo & Publicidade & Inauguração & $\begin{array}{l}\text { Governador faz } \\
\text { inauguração/entreg } \\
\text { a de Centro } \\
\text { recreativo em } \\
\text { Itapeva munido de } \\
\text { piscinas, quadras e } \\
\text { bosque, que leva o } \\
\text { nome de seu pai, } \\
\text { Centro Comunitário } \\
\text { e Recreativo Bento } \\
\text { Alves Natel, e que } \\
\text { pretende servir a } \\
20 \text { mil } \\
\text { trabalhadores. }\end{array}$ \\
\hline $\begin{array}{l}30 \text { de } \\
\text { setembr } \\
\text { o de } \\
1972 \\
\end{array}$ & $\begin{array}{l}\text { Governo do } \\
\text { Estado de } \\
\text { São Paulo } \\
\end{array}$ & Ato Executivo & Contrato & DEFE & $\begin{array}{l}\text { A Secretaria de } \\
\text { Cultura, Esporte e } \\
\text { Turismo contrata a } \\
\text { TV Record, Canal } \\
\text { 7, para o evento } \\
\text { denominado } \\
\text { Fittipaldi Show., a } \\
\text { acontecer entre os } \\
\text { dias } 9 \text { e } 19 \text { de } \\
\text { novembro no } \\
\text { Anhangabaú. } \\
\end{array}$ \\
\hline
\end{tabular}




\begin{tabular}{|c|c|c|c|c|c|}
\hline $\begin{array}{l}03 \text { de } \\
\text { outubro } \\
\text { de } 1972\end{array}$ & $\begin{array}{l}\text { Assembleia } \\
\text { Legislativa } \\
\text { de São } \\
\text { Paulo } \\
\end{array}$ & $\begin{array}{l}\text { Pronunciamen } \\
\text { to }\end{array}$ & Ao executivo & & $\begin{array}{l}\text { Deputado Pedro } \\
\text { Geraldo Costa } \\
\text { pede ao Prefeito } \\
\text { de São Paulo que } \\
\text { cubra as } \\
\text { arquibancadas do } \\
\text { Pacaembu, após } \\
\text { ida pessoal ao } \\
\text { estádio e } \\
\text { constatação de } \\
\text { que os que } \\
\text { pagavam menos } \\
\text { eram expostos a } \\
\text { chuva. }\end{array}$ \\
\hline $\begin{array}{l}07 \text { de } \\
\text { outubro } \\
\text { de } 1972 \\
\end{array}$ & $\begin{array}{l}\text { Governo do } \\
\text { Estado de } \\
\text { São Paulo } \\
\end{array}$ & Ato Executivo & Publicidade & Recursos & $\begin{array}{l}\text { Exposição sobre } \\
\text { as programações } \\
\text { contidas no } \\
\text { orçamento } \\
\text { plurianual de } 73 \text { a } \\
75 \text { - demanda de } \\
\text { esporte. }\end{array}$ \\
\hline $\begin{array}{l}13 \text { de } \\
\text { outubro } \\
\text { de } 1972\end{array}$ & $\begin{array}{l}\text { Câmara } \\
\text { municipal de } \\
\text { São Paulo }\end{array}$ & $\begin{array}{l}\text { Pronunciamen } \\
\text { to }\end{array}$ & Discussão & & $\begin{array}{l}\text { Fala sobre o } \\
\text { trabalho de Paulo } \\
\text { Machado de } \\
\text { Carvalho como } \\
\text { secretário de } \\
\text { Esportes de São } \\
\text { Paulo, e das } \\
\text { dificuldades visto } \\
\text { que o } \\
\text { Departamento de } \\
\text { Patrimônio do } \\
\text { Município não } \\
\text { colabora. }\end{array}$ \\
\hline $\begin{array}{l}13 \text { de } \\
\text { outubro } \\
\text { de } 1972 \\
\end{array}$ & $\begin{array}{l}\text { Câmara } \\
\text { Municipal de } \\
\text { São Paulo } \\
\end{array}$ & $\begin{array}{l}\text { Pronunciamen } \\
\text { to }\end{array}$ & Discussão & & \begin{tabular}{|l|} 
Fala sobre a \\
matéria da Folha \\
de São Paulo \\
sobre a prática de \\
Xadrez - vereador \\
Brasil Vitta. \\
\end{tabular} \\
\hline $\begin{array}{l}14 \text { de } \\
\text { outubro } \\
\text { de } 1972\end{array}$ & $\begin{array}{l}\text { Governo do } \\
\text { Estado de } \\
\text { São Paulo }\end{array}$ & Visita & Ao executivo & & $\begin{array}{l}\text { Em visita, é pedido } \\
\text { ao Governador de } \\
\text { se incluir São João } \\
\text { da Boa Vista no } \\
\text { programa Pró } \\
\text { Esporte, a fim de } \\
\text { acelerar as obras } \\
\text { de espaços } \\
\text { esportivos na } \\
\text { cidade. }\end{array}$ \\
\hline $\begin{array}{l}17 \text { de } \\
\text { outubro } \\
\text { de } 1972\end{array}$ & $\begin{array}{l}\text { Assembleia } \\
\text { Legislativa } \\
\text { de São } \\
\text { Paulo }\end{array}$ & $\begin{array}{l}\text { Pronunciamen } \\
\text { to }\end{array}$ & Publicidade & & \begin{tabular}{|l} 
Fala sobre o \\
adiamento dos \\
XXXVII Jogos \\
Abertos do Interior, \\
a serem feitos em \\
Osasco, por duas \\
razões, a primeira \\
por não poder \\
ceder prédios \\
escolares para o
\end{tabular} \\
\hline
\end{tabular}




\begin{tabular}{|c|c|c|c|c|c|}
\hline & & & & & $\begin{array}{l}\text { evento devido a } \\
\text { demanda de aulas, } \\
\text { a segunda devido } \\
\text { ao surto de } \\
\text { meningite naquela } \\
\text { cidade. }\end{array}$ \\
\hline $\begin{array}{l}17 \text { de } \\
\text { outubro } \\
\text { de } 1972 \\
\end{array}$ & $\begin{array}{l}\text { Assembleia } \\
\text { Legislativa } \\
\text { de São } \\
\text { Paulo } \\
\end{array}$ & $\begin{array}{l}\text { Pronunciamen } \\
\text { to }\end{array}$ & Discussão & & \begin{tabular}{|l|} 
Deputados \\
defendem a \\
decisão do \\
Governador de \\
adiar a realização \\
dos Jogos Abertos \\
do Interior - ao que \\
parece houve \\
polêmica na \\
decisão. \\
\end{tabular} \\
\hline $\begin{array}{l}19 \text { de } \\
\text { outubro } \\
\text { de } \\
11972 \\
\end{array}$ & $\begin{array}{l}\text { Governo do } \\
\text { Estado de } \\
\text { São Paulo }\end{array}$ & Ato Executivo & Publicidade & & $\begin{array}{l}\text { Anúncio de } \\
\text { construção de } 3 \\
\text { quadras iluminadas } \\
\text { de Basquete no } \\
\text { interior. }\end{array}$ \\
\hline \begin{tabular}{|l}
20 de \\
outubro \\
de 1972 \\
\end{tabular} & $\begin{array}{l}\text { Assembleia } \\
\text { Legislativa } \\
\text { de São } \\
\text { Paulo } \\
\end{array}$ & $\begin{array}{l}\text { Pronunciamen } \\
\text { to }\end{array}$ & Discussão & & \begin{tabular}{|l} 
Fala dos \\
deputados sobre a \\
integração nacional \\
realizada pelas \\
transmissões de tv \\
e rádio sobre o \\
esporte. Ode à \\
atuação de Wadih \\
Helu no esporte. \\
\end{tabular} \\
\hline $\begin{array}{l}21 \text { de } \\
\text { outubro } \\
\text { de } 1972\end{array}$ & $\begin{array}{l}\text { Assembleia } \\
\text { Legislativa } \\
\text { de São } \\
\text { Paulo } \\
\end{array}$ & $\begin{array}{l}\text { Pronunciamen } \\
\text { to }\end{array}$ & Discussão & & $\begin{array}{l}\text { Fala sobre a } \\
\text { necessidade do } \\
\text { Brasil de aprimorar } \\
\text { para competir nas } \\
\text { Olimpíadas de } 76 .\end{array}$ \\
\hline $\begin{array}{l}01 \text { de } \\
\text { novembr } \\
\text { o de } \\
1972 \\
\end{array}$ & $\begin{array}{l}\text { Assembleia } \\
\text { Legislativa } \\
\text { de São } \\
\text { Paulo } \\
\end{array}$ & Requerimento & Homenagem & & \begin{tabular}{|l|} 
Requerimento a \\
Emerson Fittipaldi \\
para que \\
compareça a \\
Assembleia para \\
receber \\
homenagens. \\
\end{tabular} \\
\hline \begin{tabular}{|l|}
09 de \\
novembr \\
o de \\
1972 \\
\end{tabular} & $\begin{array}{l}\text { Governo do } \\
\text { Estado de } \\
\text { São Paulo }\end{array}$ & Ato Executivo & Publicidade & Recursos & $\begin{array}{l}\text { Incremento } \\
\text { orçamentário de } 69 \\
\text { a } 73\end{array}$ \\
\hline $\begin{array}{l}14 \text { de } \\
\text { novembr } \\
\text { o de } \\
1972\end{array}$ & $\begin{array}{l}\text { Governo do } \\
\text { Estado de } \\
\text { São Paulo }\end{array}$ & Ato Executivo & Publicidade & Inauguração & \begin{tabular}{|l} 
Lançamento do \\
programa PRÓ- \\
ESPORTE - 50 \\
milhões para \\
unidades \\
esportivas em 400 \\
municípios.
\end{tabular} \\
\hline $\begin{array}{l}15 \text { de } \\
\text { novembr } \\
\text { o de } \\
1972 \\
\end{array}$ & $\begin{array}{l}\text { Governo do } \\
\text { Estado de } \\
\text { São Paulo }\end{array}$ & Lei & Publicidade & 727/71 & \begin{tabular}{|l|} 
Concessão de \\
Gymnasiun \\
Municipal de \\
Esportes para \\
escola superior de \\
Educação Física,
\end{tabular} \\
\hline
\end{tabular}




\begin{tabular}{|c|c|c|c|c|c|}
\hline & & & & & $\begin{array}{l}\text { em Avaré, mais } \\
\text { recurso mensal. }\end{array}$ \\
\hline $\begin{array}{l}21 \text { de } \\
\text { novembr } \\
\text { o de } \\
1972\end{array}$ & \begin{tabular}{|l} 
Assembleia \\
Legislativa \\
de São \\
Paulo \\
\end{tabular} & $\begin{array}{l}\text { Pronunciamen } \\
\text { to }\end{array}$ & Discussão & & $\begin{array}{l}\text { Discussão sobre o } \\
\text { programa PRÓ- } \\
\text { ESPORTE. }\end{array}$ \\
\hline $\begin{array}{l}24 \text { de } \\
\text { novembr } \\
\text { o de } \\
1972\end{array}$ & $\begin{array}{l}\text { Governo do } \\
\text { Estado de } \\
\text { São Paulo }\end{array}$ & Ato Executivo & Publicidade & Recursos & $\begin{array}{l}\text { Programação } \\
\text { Orçamentária do } \\
\text { Estado. }\end{array}$ \\
\hline $\begin{array}{l}25 \text { de } \\
\text { novembr } \\
\text { o de } \\
1972\end{array}$ & $\begin{array}{l}\text { Governo do } \\
\text { Estado de } \\
\text { São Paulo }\end{array}$ & Ato Executivo & Publicidade & convênio & \begin{tabular}{|l|} 
Convênio com a \\
Prefeitura de São \\
Caetano do Sul \\
para construção de \\
equipamento de \\
esportes. \\
\end{tabular} \\
\hline $\begin{array}{l}28 \text { de } \\
\text { novembr } \\
\text { o de } \\
1972 \\
\end{array}$ & \begin{tabular}{|l} 
Governo do \\
Estado de \\
São Paulo
\end{tabular} & Ato Executivo & Publicidade & Recursos & \begin{tabular}{|l|} 
Composição \\
percentual de \\
despesa do estado \\
de 1969 a 1973. \\
\end{tabular} \\
\hline $\begin{array}{l}28 \text { de } \\
\text { novembr } \\
\text { o de } \\
1972 \\
\end{array}$ & \begin{tabular}{|l} 
Governo do \\
Estado de \\
São Paulo
\end{tabular} & Ato Executivo & Publicidade & Recursos & $\begin{array}{l}\text { Evolução de } \\
\text { despesa do estado } \\
\text { por órgão do } \\
\text { Governo. } \\
\end{array}$ \\
\hline $\begin{array}{l}28 \text { de } \\
\text { novembr } \\
\text { o de } \\
1972 \\
\end{array}$ & \begin{tabular}{|l} 
Assembleia \\
Legislativa \\
de São \\
Paulo \\
\end{tabular} & Requerimento & Homenagem & 616 & $\begin{array}{l}\text { Congratulações ao } \\
\text { Esporte Clube Sírio } \\
\text { pela inauguração } \\
\text { de sua nova sede } \\
\text { social. } \\
\end{array}$ \\
\hline $\begin{array}{l}28 \text { de } \\
\text { novembr } \\
\text { o de } \\
1972\end{array}$ & $\begin{array}{l}\text { Governo do } \\
\text { Estado de } \\
\text { São Paulo }\end{array}$ & Ato Executivo & Publicidade & Recursos & \begin{tabular}{|l|} 
Quadros \\
Demonstrativos de \\
Despesa por \\
Categoria de \\
Programação.
\end{tabular} \\
\hline $\begin{array}{l}28 \text { de } \\
\text { novembr } \\
\text { o de } \\
1972\end{array}$ & $\begin{array}{l}\text { Governo do } \\
\text { Estado de } \\
\text { São Paulo }\end{array}$ & Ato Executivo & Publicidade & Recursos & $\begin{array}{l}\text { Sumário geral da } \\
\text { receita por fontes e } \\
\text { da despesa por } \\
\text { funções no } \\
\text { governo. }\end{array}$ \\
\hline $\begin{array}{l}29 \text { de } \\
\text { novembr } \\
\text { o de } \\
1972 \\
\end{array}$ & $\begin{array}{l}\text { Governo do } \\
\text { Estado de } \\
\text { São Paulo }\end{array}$ & Ato Executivo & Portaria & 672 & $\begin{array}{l}\text { Normas para } \\
\text { utilização de } \\
\text { instalações de } \\
\text { praças de esporte. }\end{array}$ \\
\hline $\begin{array}{l}02 \text { de } \\
\text { dezembr } \\
\text { o de } \\
1972 \\
\end{array}$ & $\begin{array}{l}\text { Governo do } \\
\text { Estado de } \\
\text { São Paulo }\end{array}$ & Ato Executivo & Publicidade & & $\begin{array}{l}\text { Anúncio de } \\
\text { construção de } \\
\text { quadras de esporte } \\
\text { no interior. }\end{array}$ \\
\hline $\begin{array}{l}02 \text { de } \\
\text { dezembr } \\
\text { o de } \\
1972\end{array}$ & $\begin{array}{l}\text { Governo do } \\
\text { Estado de } \\
\text { São Paulo }\end{array}$ & Ato Executivo & Publicidade & $\begin{array}{l}\text { Liberação de } \\
\text { Recursos }\end{array}$ & $\begin{array}{l}\text { Governador } \\
\text { autoriza Secretaria } \\
\text { de Educação a } \\
\text { contratar obras de } \\
\text { construção e } \\
\text { reforma de } \\
\text { escolas, incluindo } \\
\text { implantação de } \\
\text { quadras de } \\
\text { esporte, no valor } \\
\text { de Cr\$ } \\
26.149 .730,00 \text {. }\end{array}$ \\
\hline
\end{tabular}




\begin{tabular}{|c|c|c|c|c|c|}
\hline $\begin{array}{l}14 \\
\text { dezembr } \\
\text { o de } \\
1972\end{array}$ & $\begin{array}{l}\text { Governo do } \\
\text { Estado de } \\
\text { São Paulo }\end{array}$ & Ato Executivo & Contrato & convênio & $\begin{array}{l}\text { Convênio da } \\
\text { Secretaria de } \\
\text { Cultura, Esporte e } \\
\text { Turismo com o } \\
\text { Fundo de } \\
\text { Construção da } \\
\text { Universidade de } \\
\text { São Paulo - } \\
\text { Fundesp, para a } \\
\text { elaboração de } \\
\text { projeto de ginásio } \\
\text { esportivo no } \\
\text { lbirapuera e } \\
\text { construção de } \\
\text { quadras cobertas } \\
\text { na Cidade } \\
\text { Universitária } \\
\text { "Armando de Sales } \\
\text { Oliveira". }\end{array}$ \\
\hline $\begin{array}{l}22 \text { de } \\
\text { dezembr } \\
\text { o de } \\
1972\end{array}$ & 列 & $\begin{array}{l}\text { Pronunciamen } \\
\text { to }\end{array}$ & Ao executivo & & $\begin{array}{l}\text { Vereador Oswaldo } \\
\text { Girales fala da } \\
\text { construção de } \\
\text { campos e mini } \\
\text { campos que têm } \\
\text { sido feitas na } \\
\text { cidade e da } \\
\text { importância deles } \\
\text { para o uso dos } \\
\text { times varzeanos } \\
\text { que ainda se } \\
\text { ressentem de } \\
\text { terem perdido seus } \\
\text { espaços de jogo } \\
\text { onde hoje se } \\
\text { encontra o } \\
\text { Anhembi, e fala da } \\
\text { questão do Clube } \\
\text { Estrela do Pari, } \\
\text { que recebeu } \\
\text { cobrança da } \\
\text { Prefeitura e pede a } \\
\text { imunidade do } \\
\text { clube. }\end{array}$ \\
\hline $\begin{array}{l}23 \text { de } \\
\text { dezembr } \\
\text { o de } \\
1972\end{array}$ & $\begin{array}{l}\text { Governo do } \\
\text { Estado de } \\
\text { São Paulo }\end{array}$ & Ato Executivo & Publicidade & Recursos & $\begin{array}{l}\text { Resumo geral do } \\
\text { Orçamento da } \\
\text { Secretaria de } \\
\text { Cultura, Esporte e } \\
\text { Turismo. } \\
\end{array}$ \\
\hline
\end{tabular}

